\title{
Determinants of inward foreign direct investment: the case of the Netherlands
}

Citation for published version (APA):

Hogenbirk, A. E. (2002). Determinants of inward foreign direct investment: the case of the Netherlands. [Doctoral Thesis, Maastricht University]. Universiteit Maastricht. https://doi.org/10.26481/dis.20020926ah

Document status and date:

Published: 01/01/2002

DOI:

10.26481/dis.20020926ah

Document Version:

Publisher's PDF, also known as Version of record

\section{Please check the document version of this publication:}

- A submitted manuscript is the version of the article upon submission and before peer-review. There can be important differences between the submitted version and the official published version of record.

People interested in the research are advised to contact the author for the final version of the publication, or visit the DOI to the publisher's website.

- The final author version and the galley proof are versions of the publication after peer review.

- The final published version features the final layout of the paper including the volume, issue and page numbers.

Link to publication

\footnotetext{
General rights rights.

- You may freely distribute the URL identifying the publication in the public portal. please follow below link for the End User Agreement:

www.umlib.nl/taverne-license

Take down policy

If you believe that this document breaches copyright please contact us at:

repository@maastrichtuniversity.nl

providing details and we will investigate your claim.
}

Copyright and moral rights for the publications made accessible in the public portal are retained by the authors and/or other copyright owners and it is a condition of accessing publications that users recognise and abide by the legal requirements associated with these

- Users may download and print one copy of any publication from the public portal for the purpose of private study or research.

- You may not further distribute the material or use it for any profit-making activity or commercial gain

If the publication is distributed under the terms of Article $25 \mathrm{fa}$ of the Dutch Copyright Act, indicated by the "Taverne" license above, 


\section{DETERMINANTS OF \\ INWARD FOREIGN DIRECT INVESTMENT: \\ THE CASE OF THE NETHERLANDS}





\section{DETERMINANTS OF INWARD FOREIGN DIRECT INVESTMENT: THE CASE OF THE NETHERLANDS}

\section{PROEFSCHRIFT}

ter verkrijging van de graad van doctor aan de Universiteit Maastricht, op gezag van de Rector Magnificus, Prof. dr. A.C. Nieuwenhuijzen Kruseman, volgens het besluit van het College van Decanen, in het openbaar te verdedigen op donderdag 26 september 2002 om 14.00 uur

door

Anne Elisabeth Hogenbirk 


\section{Promotor:}

Prof. dr. J. Hagedoorn

\section{Co-promotor:}

Prof. dr. R. Narula (University of Copenhagen)

\section{Beoordelingscommissie:}

Prof. dr. J.D.P. Kasper

Prof. dr. L.L.G. Soete

Prof. dr. D.G.A.E. Van Den Bulcke (University of Antwerp, RUCA)

Determinants of Inward Foreign Direct Investment: The Case of the Netherlands

(C) A.E. Hogenbirk, Maastricht 2002

Proefschrift Universiteit Maastricht

ISBN 9090159797

Omslagontwerp en foto: Gera Woltjer, Veenendaal

Druk: Datawyse 
Mijn geliefde: Hans van Kranenburg Mama \& Papa Feijtus \& Wilma Andries \& Judith $\mathrm{Pa} \& \mathrm{Ma}$ Rian \& Sjaak, Willeke en Lidia John Hagedoorn Rajneesh Narula Hans Kasper, Luc Soete, Danny Van Den Bulcke LouAnne Barclay Peter Berends Vera Bröcheler Eiba Tutorial Participants Jerusalem '98 Margreet Eldering, Anneke en Matthijs Etic teachers and students Margreet ten Have Roger van Hoesel Hanneke van Kooten Astrid Kusters Maureen Lankhuizen Mathilde Leeuwenburgh Wilko \& Lotte, Rik en Maartje Letterie Cornelie van Moorsel Ellen Nelissen, Sasha en Etienne Mullers Eva Nelissen Mette \& Eddie en Kristian Praest Knudsen Caren Schelleman Wilfred Schoenmakers Nicolien Smits Kitty van Straaten Andrea Visser Jeannette \& Harmen, Tessa en Donna ter Welle Gera Woltjer Ladies ' diner dames Leesclubje-vrienden Collega's Bedrijven/directeuren die aan de enquête hebben deelgenomen 
In liefdevolle herinnering aan mijn vader

JAN CORNELIS HOGENBIRK (1942-2000)

wiens nadruk op het belang van onderwijs en ontwikkeling

van mij geen doktersassistente

maar een doctor maakte.

Mijn eerste boek naast zijn vele! 


\section{CONTENTS}

\section{Acknowledgements}

List of figures

List of tables

1 INTRODUCTION

1.1 Introduction

1.2 The impact of FDI on host economies

1.3 FDI and small countries

1.4 Research questions 9

$\begin{array}{ll}1.5 & \text { The reasons for selecting the electronics industry }\end{array}$

$\begin{array}{lll}1.6 & \text { Outline of the study } & 15\end{array}$

2 LOCATIONAL ADVANTAGES OF THE NETHERLANDS: AN INTRODUCTION

2.1 Introduction

2.2 The importance of trade in the Dutch economy 18

2.3 The "Polder"-model 22

$2.4 \quad$ Additional economic reforms in the Netherlands 24

$\begin{array}{ll}2.5 & \text { European integration } \\ 2.6 & 26\end{array}$

2.6 Outward FDI from the Netherlands 30

$\begin{array}{lll}2.7 & \text { Inward FDI in the Netherlands } & 34\end{array}$

$2.8 \quad$ Foreign establishments in the Netherlands 38

2.9 Types of foreign investments 43

$\begin{array}{lll}2.10 & \text { Conclusion } & 44\end{array}$

3 THE DETERMINANTS OF FDI IN THE NETHERLANDS: A MACRO ANALYSIS

$\begin{array}{lll}3.1 & \text { Introduction } & 46\end{array}$

3.2 Inward FDI in the Netherlands 47

$\begin{array}{lll}3.3 & \text { Brief literature review } & 49\end{array}$

$\begin{array}{lll}3.4 & \text { Hypotheses } & 56\end{array}$

$\begin{array}{lll}3.5 & \text { The model } & 61\end{array}$

$\begin{array}{lll}3.6 & \text { Data and variables } & 63\end{array}$

$\begin{array}{lll}3.7 & \text { Results } & 63\end{array}$

$\begin{array}{lll}3.8 & \text { Discussion } & 67\end{array}$

$\begin{array}{lll}3.9 & \text { Conclusion } & 70\end{array}$

$\begin{array}{ll}\text { Appendix } 3.1 \text { The data } & 72\end{array}$

4 AGGLOMERATION IN DUTCH INWARD FOREIGN INVESTMENTS

$\begin{array}{lll}4.1 & \text { Introduction } & 75\end{array}$

$\begin{array}{lll}4.2 & \text { Foreign establishments in the Netherlands } & 76\end{array}$ 
4.3 A brief overview of studies on locational choice $\quad 78$

4.4 Hypotheses $\quad 85$

4.5 The model 91

4.6 The data 92

4.7 Results 95

$\begin{array}{lll}4.8 & \text { Discussion } & 100\end{array}$

$\begin{array}{lll}4.9 & \text { Conclusion } & 103\end{array}$

5 DETERMINANTS OF FDI ACTIVITY IN THE DUTCH ELECTRONICS INDUSTRY

$\begin{array}{lll} & \text { Introduction } & 104\end{array}$

5.2 Theoretical foundations of the OLI paradigm 106

$\begin{array}{ll}\text { 5.2.1 Ownership advantages } & 107\end{array}$

5.2.2 Internalisation advantages $\quad 109$

$\begin{array}{ll}5.2 .3 \text { Locational advantages } & 110\end{array}$

$\begin{array}{lll}5.3 & \text { Hypotheses } & 111\end{array}$

$\begin{array}{ll}\text { 5.3.1 Ownership advantages } & 111\end{array}$

5.3.2 Internalisation advantages $\quad 112$

5.3.3 Locational advantages $\quad 113$

$\begin{array}{lll}5.4 & 119\end{array}$

$\begin{array}{lll}5.5 & \text { The data } & 121\end{array}$

5.6 Testing the OLI for foreign electronics affiliates in the Netherlands 123

$\begin{array}{ll}\text { 5.6.1 Ownership advantages } & 123\end{array}$

5.6.2 Internalisation advantages $\quad 128$

5.6.3 Locational advantages $\quad 129$

5.6.4 Overall results $\quad 137$

$\begin{array}{lll}5.7 & \text { Discussion } & 138\end{array}$

5.7.1 Ownership 139

5.7.2 Internalisation $\quad 140$

5.7.3 Location $\quad 140$

5.7.4 Limitations $\quad 142$

$\begin{array}{lll}5.8 & \text { Conclusion } & 143\end{array}$

$\begin{array}{ll}\text { Appendix 5.1 Reliability analyses } & 145\end{array}$

6 DETERMINANTS OF THE SALES FOCUS OF FOREIGN AFFILIATES IN THE NETHERLANDS

$\begin{array}{lll}6.1 & 152\end{array}$

6.2 Conceptual framework and hypotheses 153

$\begin{array}{ll}6.3 & 159\end{array}$

$\begin{array}{ll}6.4 & 162\end{array}$

$\begin{array}{lll}6.5 & \text { Results } & 164\end{array}$

$\begin{array}{lll}6.6 & 169\end{array}$

$\begin{array}{lll}6.7 & \text { Conclusion } & 170\end{array}$

$\begin{array}{ll}\text { Appendix 6.1 Dataoverview } & 171\end{array}$ 


\section{CONCLUSION}

$\begin{array}{lll}7.1 & \text { Introduction } & 173\end{array}$

$\begin{array}{lll}7.2 & \text { Overall conclusions } & 174\end{array}$

7.2.1 Presence of foreign firms in the Netherlands $\quad 174$

7.2.2 Reasons for foreign MNEs to locate in the Netherlands $\quad 176$

7.2.3 Behaviour of foreign affiliates in the Netherlands 177

$\begin{array}{ll}7.3 & \text { Strengths and limitations } \\ 7.478\end{array}$

$\begin{array}{lll}7.4 & \text { Suggestions for further research } & 179\end{array}$

\section{APPENDICES}

A Description of the DutchInvest database

B Questionnaire

C Questionnaire methodology

D Deterrents in doing business in the Netherlands

Nederlandse samenvatting (Summary in Dutch) 


\section{LIST OF TABLES}

1.1 Geographical distribution of FDI in the world 5

1.2 Characteristics of OECD countries 7

1.3 The largest 20 MNEs in the world, $1998 \quad 12$

1.4 The world's largest electronics MNEs, $1998 \quad 14$

2.1 Most important Dutch trading partners 21

$\begin{array}{ll}2.2 & \text { Sectoral composition in several large FDI hosts } \\ 2.3\end{array}$

2.3 Economic indicators 23

2.4 Profile of large Fortune 500 MNEs from small industrialised countries, 2000

2.5 Stock and growth of Dutch FDI abroad, 1999

2.6 Dutch direct investments in the most important EU countries 33

2.7 Stock and growth of FDI in the Netherlands, $1999 \quad 36$

2.8 Inward FDI in the Netherlands by the most important EU countries 37

$2.9 \quad$ Examples of large foreign investors in the Netherlands 39

2.10 Cross-border M\&A deals with values of over US\$2 billion 40

2.11 Home countries of foreign establishments in the Netherlands 41

2.12 Companies in the Netherlands, $1 / 1 / 1997$, grouped by activity 42

3.1 Stock of inward FDI in the Netherlands, several years 48

3.2 FDI stock in the Netherlands by country, $1999 \quad 49$

3.3 Overview of the finding of empirical studies on the macro-economic determinants of FDI flows $\quad 52$

3.4 Overview of the countries in the study 62

3.5 Regression results of FDI flows into the Netherlands 64

3.6 Hypotheses tests 66

3A.1 Overview of the variables used in the empirical study 72

$\begin{array}{lll}3 \text { A.2 Correlation matrix } & 74\end{array}$

4.1 Dutch establishment pattern of local and foreign firms per region 78

4.2 Overview of the findings of empirical studies on the determinants of location choice

4.3 Counts and home countries of new foreign establishments in the Netherlands 
4.4 Explanatory variables $\quad 94$

4.5 Regression results 96

4.6 Hypotheses tests 98

4.7 New establishments per region of firms from different home countries $\quad 100$

5.1 Representativeness of the responding firms

5.2 Characteristics of the firms responding to the questionnaire 123

5.3 Competitive strengths of foreign firms in the Dutch electronics industry 124

$\begin{array}{ll}5.4 & \text { Differences in strength according to firm characteristics } \\ & 126\end{array}$

$\begin{array}{ll}5.5 & \text { Factors of competitive strength } \\ & 127\end{array}$

$\begin{array}{llr}5.6 & \text { Internalisation reasons } & 128\end{array}$

$\begin{array}{lll}5.7 & \text { Factor analysis internalisation } & 129\end{array}$

5.8 Overview of the locational determinants of FDI in the Netherlands $\quad 130$

5.9 Differences in locational determinants according to firm characteristics 132

5.10 Factors of locational determinants 135

$\begin{array}{lll}5.11 & \text { Hypotheses tests } & 138\end{array}$

5A.1 Assessment of reliability: Firm's strength (total sample) 145

5A.2 Assessment of reliability: Firm's strength (specified constructs) 145

5A.3 Assessment of reliability: Firm's strength (factor analysis) 146

5A.4 Assessment of reliability: Internalisation (total sample) 147

5A.5 Assessment of reliability: Internalisation (factor analysis) 147

5A.6 Assessment of reliability: Location (total sample) 148

5A.7 Assessment of reliability: Location (7 specified groups of variables) $\quad 148$

5A.8 Assessment of reliability: Location (factor analysis) 150

6.1 Overview of the variables used in the empirical study 163

$\begin{array}{ll}\text { 6.2 Descriptive statistics of the sample } & 164\end{array}$

6.3a Correlation matrix binary choice model of sales focus 164

6.3b Correlation matrix multinomial choice model of sales focus 165

6.4 Determinants of the sales focus of FDI into the Dutch electronics industry (binomial)

6.5 Determinants of the sales focus of FDI into the Dutch electronics industry (multinomial)

6.6 Hypotheses tests

6A.1 Descriptive statistics NL/other

6A.2 Descriptive statistics per group: 3 foci 
6A.3 Descriptive statistics per group

A1 Vintage of foreign investments present in the Netherlands in $1997 \quad 183$

A2 Regional spread of foreign establishments in the Netherlands in $1999 \quad 184$

A3 Sectoral distribution of foreign establishments in the Netherlands in $1999 \quad 184$

A4 Country of origin of investments in the Netherlands, 1997

C1 Response to the first mailing 210

C2 Response to the second mailing 211

$\begin{array}{ll}\text { C3 Results of the study } & 212\end{array}$

C4 Representativeness of the response 213

D1 Issues of concern in doing business in the Netherlands 217

D2 Differences in problems depending on home country of affiliate 218

D3 Differences in problems depending on the sales focus of the affiliate $\quad 219$

D4 Factors showing the issues of concern of foreign entrepreneurs in the Netherlands 


\section{LIST OF FIGURES}

1.1 Relationship between country size and exports

1.2 Overview of the study

$2.1 \quad$ Map of Europe

2.2 Map of the Netherlands

2.3 Dutch FDI flows, 1968-1998

3.1 Inward FDI determinants

3.2 Hypothesised relationships

4.1 Map of foreign establishments in the Netherlands

4.2 Determinants of regional location choice

4.3 Hypothesised relationships

5.1 The Eclectic Paradigm

5.2 Hypothesised relationships

6.1 Classification of affiliate activities

6.2 Determinants of the affiliate's sales focus

6.3 Classification of survey firms

C1 A classification of research data

C2 A classification of survey methods 
tak

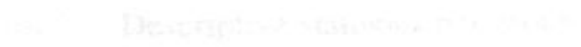

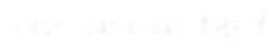

and

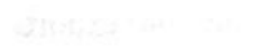

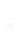

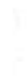

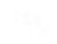

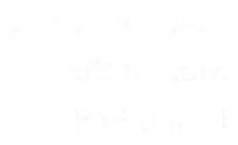

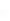

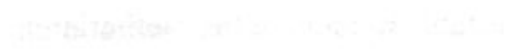

.

$\left(\frac{10}{2}\right.$

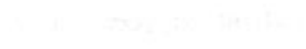

-

.

.

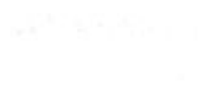

(1)

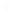

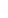

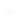

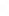

(2)

, 


\section{Chapter one}

INTRODUCTION

\subsection{Introduction}

This thesis studies the business activities of foreign firms in a small industrialised economy: the Netherlands. Since World War II, the number and importance of foreign establishments in the Netherlands has increased considerably (Nieuwkerk and Sparling 1985, Loeve 1986, Beers et al. 1999, Wintjens 2001). This development coincides with a world-wide upsurge in foreign direct investments (FDI) by multinational enterprises (MNEs) (Levitt 1983, Ohmae 1985, Bartlett and Ghoshal 1989, United Nations 1997, $1998,1999,2000)$. For many firms the internationalisation of their activities has become a prerequisite for survival in the globalising world economy. When, for example, the home market is not large enough or the local competition is too strong, firms look for new opportunities - frequently outside their home market - to either decrease the costs or increase the benefits of their activities. The number of MNEs conducting activities through establishments in more than one country has therefore increased from 7,000 in the late 1960 s to 63,000 in 1999 . Together these parent firms own and control over 690,000 affiliates outside their home market (United Nations 2000). In addition to these affiliates, MNEs also have a wide spectrum of non-equity arrangements (such as franchising, licensing, subcontracting, and alliances) with other local and foreign firms (Hagedoorn and Narula 1996). The MNE is therefore often seen as the coordinator of a complex network of interrelated value-adding activities (Dunning 1994).

The rapid expansion of international production and cooperation by MNEs has been facilitated by the process of economic globalisation ${ }^{1}$ that results in the rapid internationalisation of previously national economies and an increasingly interconnected world economy (Govindarajan and Gupta 2000). Three mutually enforcing factors account for this development (Fraser and Oppenheim 1997). First of all, the increasing irrelevance of national borders as economic barriers fall, the regulatory environment of countries changes, and liberalisation occurs (e.g. the collapse of the Berlin wall, liberalisation in Latin America, increasing number of countries that embrace the freemarket ideology such as those in Eastern Europe). Second, the growing scale, mobility,

\footnotetext{
${ }^{1}$ Globalisation can be defined as the process by which the world's economy is transformed from a set of national and regional markets into a set of markets that operate without regard to national boundaries (Fraser and Oppenheim 1997). Globalisation results in increasing interdependence among countries as reflected in increasing cross-border integration of production and markets for goods and services, capital, and know-how (Govindarajan and Gupta 2000, Narula and Dunning 2000).
} 
and integration of the world's capital markets that facilitates the transfer of capital across country borders ${ }^{2}$. And third, the expanding ability to leverage knowledge and talent world-wide through new and rapidly developing information, communication, and computer technology.

Globalisation has affected individual economies substantially, particularly by rising FDIflows, through which MNEs own and control factors of production in foreign locations. Since 1981, FDI flows have consistently grown faster than gross domestic product (GDP) or exports on a world-wide basis. While income and trade doubled between 1982 and 1994, the stock of FDI - a broad measure of the capital component of international production - quadrupled to an amount corresponding to almost 9 percent of world income in 1996 (United Nations 1997). At the end of 1999, the stock of FDI stood at US\$ 5 trillion. Sales by foreign affiliates - a broad measure of the revenues generated by international production - reached an estimated US\$ 14 trillion in $1999^{3}$, twice as high as global exports of goods and non-factor services (amounting to US\$ 6.9 trillion in that year). Affiliates' gross product (value added) stood at an estimated US\$ 3 trillion. The gross product of all MNEs together (parents and affiliates combined) was an estimated US\$ 8 trillion in 1997, comprising roughly a quarter of the world's GDP (United Nations 2000). MNEs therefore clearly dominate world production of goods and services.

\subsection{The impact of FDI on host economies}

Given the considerable and growing importance of international production to the world economy, the influence of MNEs on the economic future of a country can be huge. Many governments welcome FDI inflows nowadays (Dunning 1994, Narula and Dunning 2000). Although the impact of FDI on host economies depends on country-, industry-, and firm-specific characteristics and the kind of FDI being undertaken ${ }^{4}$, it is generally believed that foreign MNEs can contribute to the economic well-being of host countries (Dunning 1993) and an advancement of the host economy's competitiveness. In contrast to portfolio investments, FDI involves not only financial flows, but also transfers of materials, components, finished products, and intangible assets, e.g. in the form of knowledge about production processes, markets, distribution channels, and management (Andersson et al. 1996, Jansen 1995).

\footnotetext{
${ }^{2}$ Within the European Union, this process is further enhanced by the introduction of the single currency, the euro, as a scriptural currency in eleven member states (Austria, Belgium, Finland, France, Germany, Ireland, Italy, Luxembourg, the Netherlands, Portugal, and Spain) in 1999. January $1^{\text {st }}, 2002$, the euro banknotes and coins were introduced in all participating member states (now twelve, after Greece joined January $\left.1^{\text {st }}, 2001\right)$.

${ }^{3}$ In 1998, some of the world's largest MNEs, such as General Electric, General Motors, Ford Motor Company, Daimler Chrysler, and Mitsubishi had sales of over US\$ 100 billion, exceeding the GDP of countries such as Chile, Egypt, Ireland, and Singapore (United Nations 2000, World Bank 2000).

${ }^{4}$ For an overview of studies investigating the impact of FDI see Dunning (1994).
} 
Dicken (1992, 1998) distinguishes five major areas where MNEs impact the host economy ${ }^{5}$. The first is capital and finance. MNEs most obvious and immediate influence on a host economy is through the inflow of capital (that is when the investment is not funded on the local market in which case crowding out of local investments could occur). When after some time profits are reinvested locally, the capital injection in the host economy grows. However, an outflow of capital may also occur when the affiliate's profits are remitted to the parent country. Furthermore, interests, dividends, royalties, and management fees paid to the headquarters also result in outflows of capital. Transfer pricing to avoid tax payments in the host economy forms an additional potential financial problem that may reduce the benefit of foreign activities. The net result depends on the balance between outflows and inflows.

The second area of influence involves technology. MNEs are regarded as central to the creation and diffusion of knowledge, within and between firms, and in cooperation with governments (Dunning 1993, Dunning 1994, Safarian 1999). FDI and technology spillovers can contribute to the building or upgrading of local innovative capabilities in the host economy. This development and the diffusion of knowledge is essential for endogenous growth. The impact of the technology transfer depends on the appropriateness of the technology and the host economy's cost of acquiring the technology (Narula 2001).

The third area is trade and linkages. MNEs play an important role in the host economy's trade with the outside world. Exports by MNEs may for instance open up additional markets. Furthermore, the MNE may enable the host country to tap into, or monitor the competitive advantages of other economies (Dunning 1994). MNE trade activities influence the host economy's balance of payments. Exports and import-substituting production by MNEs contribute towards a positive trade balance while imports by the MNEs may cause a negative trade balance (Dicken 1992). However, in the long-run, host countries are more significantly influenced by the extent to which the MNEs are integrated in the local economy than by their trade relations. Linkages with indigenous firms are the most significant means by which technology is transferred and additional employment is created. Furthermore, MNEs may stimulate efficiency of suppliers through these local linkages and may raise quality standards (Dunning 1994).

The fourth impact area is industrial structure and entrepreneurship. Dunning (1993) distinguishes four distinct ways in which MNEs can influence the production system in a host economy. First of all, the efficiency in producing a particular product or range of products (technical efficiency). Second, the efficiency of allocating resources and

\footnotetext{
${ }^{5}$ Although this section focuses mostly on the many potential positive contributions of FDI to the host economy, it may also have adverse effects. Negative influences may occur, for instance, when the funds are borrowed in the local market and crowd-out local investments. Furthermore, crowding out can also occur in the commodity and factor markets in case the foreign investors claim scarce resources (such as import licenses, skilled manpower, credit facilities, etc.) or when foreign investors foreclose investment opportunities for local investors (Jansen 1995).
} 
capabilities between different value-adding activities (allocative efficiency). Third, the efficiency with which firms in particular sectors can fully exploit the economies of size (scale and scope efficiency). And finally, the efficiency with which resources and capabilities are reallocated between uses to meet changing supply and demand needs (structural adjustment efficiency) (Dunning 1993). The industry structure is also influenced when MNE investments invite complementary local or foreign private investments that provide inputs for or use outputs of the foreign investment (Jansen 1995). Furthermore, inward FDI may foster the geographical clustering of related activities that generate their own agglomeration economies (Dunning 1994). In addition, inward FDI may steer local economic activity towards the production of goods and services deemed most appropriate by domestic and international markets (Dunning 1994).

Finally, MNEs also influence local employment and labour issues. By hiring and training local employees, their activity impacts the use and upgrading of human resources and competencies without which very little economic progress can be achieved (Dunning 1993). FDI can also result in spillovers of organisational capabilities (Narula and Dunning 2000) and inject new management talent and entrepreneurial initiatives (Dunning 1994). Furthermore, indirect effects occur when additional employment is generated among the affiliate's local suppliers and customers ${ }^{6}$.

\subsection{FDI and small economies}

Table 1.1 shows the geographical distribution of the FDI stock in the world. From the table it is clear that the bulk of investments still takes place in the industrialised world, although developing countries are slowly increasing in importance, both as inward and outward investors. The United States (US) and the United Kingdom (UK) are the most important sources and hosts of FDI flows. Germany, France, the Netherlands, Belgium and Luxembourg, and Canada follow at some distance. Although the internationalisation of firms affects the nature of economic activities in virtually every country, whether rich or poor, large or small, open or closed, most studies on FDI have been concerned with

\footnotetext{
${ }^{6}$ Aside from the positive influences, there also exists considerable concern over the violation of human rights by multinational enterprises (Muchlinski 2001) and the working conditions for labourers in sweatshops (Hernaghan 1999). The operations of Shell in Ogoniland and BP in Colombia have drawn the media's attention. Governments set the legal boundaries within which the MNE operates. In addition, several codes of conduct (such as the ILO Tripartite Declaration of Principles Concerning Multinational Enterprises and Social Policy of 1977 and the OECD Guidelines for Multinational Enterprises of 1976), though non-binding, create an expectation of what is expected of multinationals related to their social responsibility. The OECD guidelines, for instance, expect the MNE to respect the right of its employees to be represented by trade unions and to contribute to the abolition of child labour. Furthermore, MNEs are expected to eliminate all forms of forced or compulsory labour, and not to discriminate against the employees with respect to employment or occupation, or on such grounds as race, colour, sex, political opinion, national extraction, or social origin (Muchlinski 2001).
} 
MNEs based in the largest industrialised economies that are also the most important investors (particularly the US and the UK).

Table 1.1 Geographical distribution of FDI in the world

\begin{tabular}{|c|c|c|c|c|c|c|}
\hline \multirow[b]{2}{*}{ Area/Country } & \multicolumn{3}{|c|}{$\begin{array}{c}\text { Share of Inward Stock of FDI } \\
(\%)\end{array}$} & \multicolumn{3}{|c|}{$\begin{array}{c}\text { Share of Outward Stock of FDI } \\
(\%)\end{array}$} \\
\hline & 1980 & 1990 & 1998 & 1980 & 1990 & 1998 \\
\hline Developed countries & 73.76 & 78.87 & 68.14 & 97.39 & 95.72 & 90.23 \\
\hline Developing countries & 26.24 & 20.96 & 29.83 & 2.61 & 4.26 & 9.49 \\
\hline Central and Eastern Europe & N.A. & 0.17 & 2.04 & 0.00 & 0.02 & 0.28 \\
\hline United States & 16.39 & 22.33 & 21.40 & 42.91 & 25.39 & 24.13 \\
\hline United Kingdom & 12.44 & 12.37 & 7.99 & 15.68 & 13.57 & 12.11 \\
\hline Germany & 7.23 & 6.29 & 5.60 & 8.41 & 8.84 & 9.47 \\
\hline France & 4.51 & 4.89 & 4.38 & 3.51 & 6.42 & 5.89 \\
\hline Netherlands & 3.78 & 4.16 & 4.15 & 8.21 & 6.36 & 6.39 \\
\hline Belgium and Luxembourg & 1.44 & 3.30 & 4.01 & 1.18 & 2.37 & 3.13 \\
\hline Canada & 10.69 & 6.38 & 3.47 & 4.63 & 4.95 & 3.80 \\
\hline Spain & 1.01 & 3.73 & 2.91 & 0.24 & 0.91 & 1.66 \\
\hline Italy & 1.76 & 3.28 & 2.58 & 1.43 & 3.27 & 4.15 \\
\hline Switzerland & 1.68 & 1.91 & 1.47 & 4.19 & 3.83 & 4.29 \\
\hline Sweden & 0.72 & 0.70 & 1.32 & 0.73 & 2.89 & 2.27 \\
\hline Denmark & 0.83 & 0.52 & 0.78 & 0.40 & 0.43 & 0.87 \\
\hline Japan & 0.65 & 0.56 & 0.74 & 3.82 & 11.93 & 7.19 \\
\hline Austria & 0.62 & 0.56 & 0.62 & 0.10 & 0.25 & 0.41 \\
\hline Norway & 1.30 & 0.70 & 0.59 & 0.11 & 0.64 & 0.80 \\
\hline Ireland & 0.74 & 0.31 & 0.58 & n.a. & 0.13 & 0.16 \\
\hline Greece & 0.89 & 0.79 & 0.54 & n.a. & 0.05 & 0.02 \\
\hline Portugal & 0.50 & 0.53 & 0.52 & 0.02 & 0.03 & 0.18 \\
\hline Finland & 0.11 & 0.29 & 0.38 & 0.14 & 0.65 & 0.80 \\
\hline Latin America and the Caribbean & 9.41 & 6.45 & 10.17 & 0.54 & 0.74 & 1.37 \\
\hline South, East, and South-East Asia & 14.44 & 10.44 & 16.07 & 1.77 & 2.48 & 7.43 \\
\hline
\end{tabular}

Source: World Investment Report (1999), n.a. is not available for that particular year

Note: The countries are ordered by their share in total inward FDI stock in 1998.

However, the eminent growth of the number of small countries during the last century ${ }^{7}$ and the considerable influence MNEs can have on a small economy - in terms of

\footnotetext{
${ }^{7}$ At the outbreak of World War I, only 62 independent countries existed. Since World War II this number has increased from 74 in 1946 to 193 in 1998 (The Economist 1998). This growth can be attributed to several forces. The end of the colonial rule has resulted in the independence of many, particularly African, states. Furthermore, the recent political disintegration of larger countries into smaller separate sovereign states - such as the collapse of the Soviet Union (1991) resulting in 15 separate nations, the
} 
employment, trade, and knowledge creation/transfer - justify a separate analysis of the determinants of the FDI flows to small economies. In general, it is expected that the limited market size and lack of resources in small economies makes them relatively unattractive as a location for foreign affiliates and gives them little bargaining power with respect to MNEs. Still, despite these disadvantages some economies (the Netherlands, Belgium/Luxembourg, Sweden, Switzerland) did attract considerable FDI flows, as was illustrated in Table 1.1.

There is little consensus in the literature on the subject of small economies on the appropriate use of size measures and size thresholds (Armstrong and Read 1998, Gutierrez 1996). The economic literature generally attempts to conceptualise the issue of size in terms of measurable variables, such as population, aggregate economic activity (GDP/GNP), geographic area, availability of various natural resources, technological level, rate of growth, and degree of dependence on other countries (Walsh 1988). Population is most commonly used, primarily because it is easily available. It also provides a very crude proxy for two economic variables: size of the domestic market and the local labour force (Armstrong and Read 1998) ${ }^{8}$. Given the relatively small FDI flows to developing countries, we focus this study on small, industrialised economies. Following Walsh (1988), we classify them as those OECD-countries that have a population below 25 million?.

In general, most economies that are small in terms of total population also have a limited geographic area. The (geographically) smallest of the large (in terms of population) OECD countries, Korea, has $99,000 \mathrm{~km}^{2}$ land area. The other 11 are much larger. Of the 17 small OECD-countries listed in Table 1.2, ten have even smaller land areas than Korea and only Sweden and Australia have more than $350,000 \mathrm{~km}^{2}$. Armstrong and Read (1998) argue that this limited size usually results in less diversity in raw materials and natural resources. Even if resources are abundant, the capital requirements for the exploitation can be beyond the financial means of the small economy and require capital inflows (reducing the domestic retained value ${ }^{10}$ ). This lack of raw materials and natural resources can make small economies relatively unattractive for large MNEs that want to exploit those resources.

For most small economies, the domestic market (proxied by GDP) is relatively small. If low GDP results in restricted purchasing power of local consumers, firms from small

separation of Czechoslovakia (1993), and the disintegration of the Yugoslav Federation (1992) increased the number of independent countries (Armstrong and Read 1998).

${ }^{8}$ Eighty-seven of the 193 current nations have populations of less then five million. Of those, thirty-five even have less than 500,000 inhabitants (The Economist 1998). Among the small are both developed (Luxembourg, Iceland) and developing countries (Cape Verde, Equatorial Guinea) (Gutierrez 1996).

${ }^{9}$ Armstrong and Read (1998) consider countries with total population under three million to be small while Gutierrez (1996) uses 12 million as the cut-off.

${ }^{10}$ In addition, the mineral extraction may involve serious pollution in the form of toxic waste, oil and chemical spills, deforestation, air pollution and contamination of soil and water supplies (Oxfam 2001). Local governments must make sure that this damage is prevented or compensated for. 
economies will crucially depend on international sales to achieve economies of scale in production and recoup the money spend on R\&D (Walsh 1988).

Table 1.2 Characteristics of OECD countries

\begin{tabular}{|c|c|c|c|c|c|c|c|c|}
\hline Country & & $\begin{array}{l}\text { GDP } \\
1998 \\
\text { (mln } \\
\text { US\$) }\end{array}$ & $\begin{array}{l}\text { POP } \\
(\mathrm{mln})\end{array}$ & $\begin{array}{c}\text { GNP } \\
\text { per } \\
\text { capita } \\
1999 \\
\text { (US\$) }\end{array}$ & $\begin{array}{c}\text { Area } \\
1996 \\
(1000 \\
\left.\mathrm{km}^{2}\right)\end{array}$ & $\begin{array}{c}\text { Inward } \\
\text { FDI } \\
\text { Stock } \\
1999 \\
\text { (bln } \\
\text { US\$) }\end{array}$ & $\begin{array}{c}\text { Export } \\
\text { (\% } \\
\text { GDP) } \\
1999\end{array}$ & $\begin{array}{c}\text { Import } \\
\text { (\% } \\
\text { GDP) } \\
1999\end{array}$ \\
\hline \multicolumn{9}{|l|}{ Small economies } \\
\hline Iceland & IS & 8415 & 0.3 & 29280 & 103 & 0.529 & 29.6 & 37.4 \\
\hline Luxembourg & LU & 14700 & 0.4 & 44640 & 3 & $*$ & 51.0 & 65.3 \\
\hline Ireland & IE & 81949 & 3.7 & 19160 & 70 & 43.969 & 59.6 & 59.7 \\
\hline New Zealand & $\mathrm{NZ}$ & 52845 & 3.8 & 13780 & 271 & 33.217 & 19.1 & 17.6 \\
\hline Norway & NO & 145892 & 4.4 & 32880 & 324 & 30.885 & 42.5 & 34.7 \\
\hline Finland & FI & 123502 & 5.2 & 23780 & 338 & 16.540 & 39.6 & 28.3 \\
\hline Denmark & DK & 17487 & 5.3 & 32030 & 43 & 37.830 & 38.8 & 34.4 \\
\hline Switzerland & $\mathrm{CH}$ & 263630 & 7.1 & 38350 & 41 & 73.099 & 50.0 & 50.3 \\
\hline Austria & AT & 211858 & 8.1 & 25970 & 84 & 23.363 & 33.0 & 36.7 \\
\hline Sweden & SE & 226492 & 8.9 & 25040 & 450 & 68.035 & 46.6 & 36.9 \\
\hline Portugal & PT & 106697 & 10.0 & 10600 & 92 & 20.513 & 16.5 & 23.1 \\
\hline Hungary & $\mathrm{HU}$ & 47807 & 10.1 & 4650 & 93 & 19.095 & 28.5 & 31.6 \\
\hline Belgium & $\mathrm{BE}$ & 248184 & 10.2 & 24510 & 33 & 181.184 & 77.0 & 71.0 \\
\hline Czech Republic & $\mathrm{CZ}$ & 56379 & 10.3 & 5060 & 79 & 16.246 & 22.3 & 24.0 \\
\hline Greece & GR & 120724 & 10.5 & 11770 & 132 & 22.948 & 8.3 & 18.6 \\
\hline Netherlands & NL & 381819 & 15.7 & 24320 & 41 & 215.234 & 46.3 & 41.6 \\
\hline Australia & $\mathrm{AU}$ & 361722 & 18.8 & 20050 & 7741 & 118.600 & 13.9 & 16.1 \\
\hline \multicolumn{9}{|l|}{ Large economies } \\
\hline Canada & $\mathrm{CA}$ & 580623 & 30.3 & 19320 & 9971 & 166.266 & 38.3 & 35.9 \\
\hline Poland & PL & 158574 & 38.7 & 3960 & 323 & 29.979 & 10.1 & 14.8 \\
\hline Spain & ES & 553230 & 39.4 & 14000 & 506 & 112.582 & 16.6 & 20.3 \\
\hline Korea & $\mathrm{KR}$ & 320748 & 46.4 & 8490 & 99 & 27.984 & 23.0 & 18.5 \\
\hline Italy & IT & 1171865 & 57.6 & 19710 & 301 & 107.995 & 20.0 & 17.1 \\
\hline France & FR & 1426967 & 58.8 & 23480 & 552 & 181.974 & 22.2 & 20.5 \\
\hline United Kingdom & UK & 1357197 & 59.1 & 22640 & 245 & 394.560 & 21.0 & 23.7 \\
\hline Turkey & TR & 198844 & 63.5 & 2900 & 775 & 8.353 & 6.4 & 9.8 \\
\hline Germany & $\mathrm{DE}$ & 2134205 & 82.0 & 25350 & 357 & 225.595 & 32.7 & 31.5 \\
\hline Mexico & MX & 393508 & 95.8 & 4400 & 1958 & 72.016 & 15.8 & 16.4 \\
\hline Japan & JP & 3782964 & 126.4 & 32230 & 378 & 33.806 & 14.0 & 10.4 \\
\hline United States & US & 8230397 & 270.3 & 30600 & 9364 & 1087.289 & 7.2 & 9.9 \\
\hline
\end{tabular}

Sources: World Bank World Development Indicators 2000, CIA factbook online, UN World Investment Report 2000

* Inward FDI Stock figures are for Belgium and Luxembourg together. 
Furthermore, small economies also tend to be more heavily dependent on foreign sources of supply. International trade is therefore much more important for a small economy than for a large one (Streeten 1993, Armstrong and Read 1998, Dunning 1998, The Economist 1998). This openness is reflected in a high share of trade to GDP. Table 1.2 and Figure 1.1 illustrates this fact for the 29 OECD-countries. The smaller OECD countries (such as Luxembourg, Ireland, Belgium, and the Netherlands) generally have larger export- and import-ratios than the larger ones (such as the US and Japan). This openness results in a high degree of exposure to exogenous shocks f.e. in terms of export prices in the international economy (Gutierrez 1996), fluctuating exchange rates (Walsh 1988), and the World Trade Centre attack on September $11^{\text {th }}, 2001$.

Figure 1.1

Relationship between country size and exports

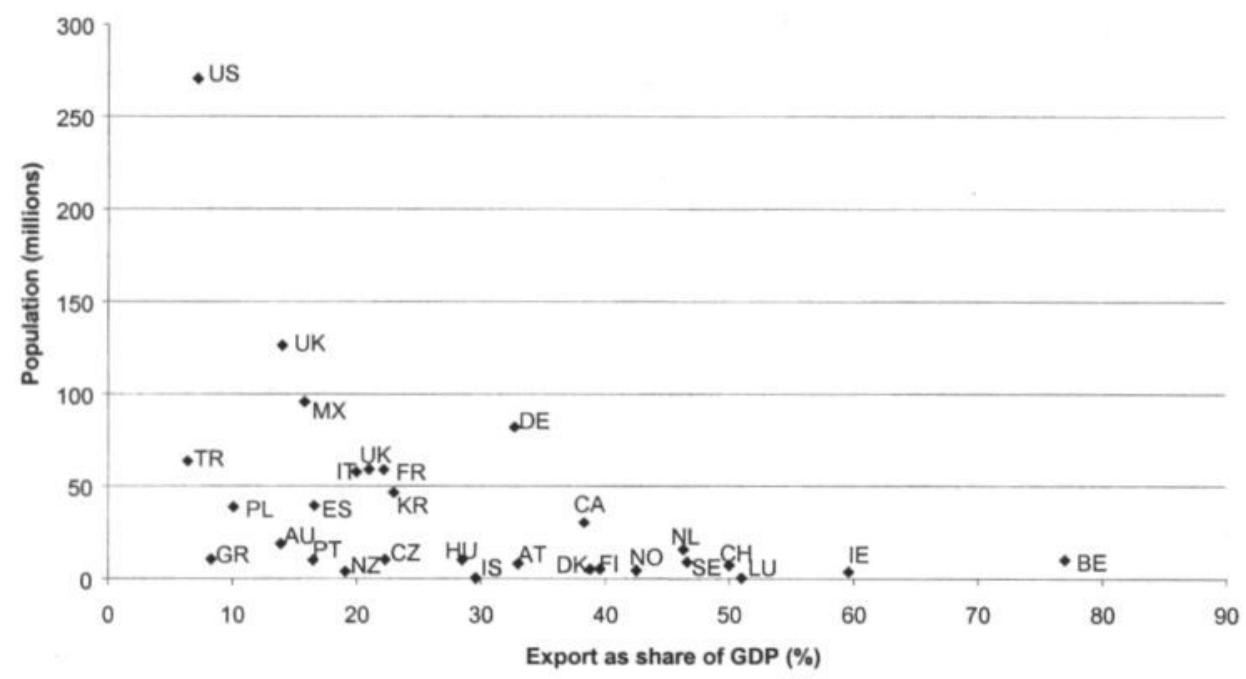

Considering that domestic demand for goods and services produced by MNEs is generally below the minimum efficient scale in small economies, the costs of local output of a wide range of goods and services will be relatively high (Armstrong and Read 1998). Small economies are therefore likely to specialise in niche sectors in which they have a comparative advantage (in many cases high-value added sectors that need specialised human capital) (Benito et al. 2000). Large firms or even large economy small firms do not bother with these niches, or are too inflexible to do so.

Related to this focus on niches is the disadvantage many small economies have in the development of new innovations. On average, small economies have less money to spend and fewer people to commit to research and development (R\&D) than their larger counterparts (Walsh 1988, Cadot and Desruelle 1998). Generally, the bulk of R\&D in 
small economies is carried out by the public sector (Hadjimanolis and Dickson 2001) and is more focused on basic research than on product development (Cadot and Desruelle 1998). Furthermore, the proximity of users to the suppliers of an innovation plays an important role in the design and de-bugging of new (especially high-technology) products. With a relatively limited number of local users, this process is more difficult (Walsh 1988). Given that the indigenous development of new technologies is difficult, many small economies therefore tend to focus more on technology diffusion in the form of absorption and adaptation of foreign technologies (Edquist and Lundvall 1993). Considering that technological progress has become a key factor in competitiveness and survival, this situation makes many small economies - particularly those lacking large globally operating firms with international R\&D activities - quite vulnerable.

Many small economies explore possibilities for regional economic and political integration. Within a trade-block the importance of the (small) domestic market diminishes (Andersson et al. 1996, Casella 1995). Local firms will be able to reach customers in the entire integrated region more easily than they could before the trade block was established. The integration process may therefore attract foreign firms to the region (and to the small economies that make up the region) that want to benefit from the positive effects of integration.

\subsection{Research questions}

We focus our attention in this study on the Netherlands, as an example of a small industrialised economy that actively participated in a regional integration process. Although small and therefore potentially unattractive as a location for MNE-affiliates, the Netherlands has managed to attract considerable FDI flows, amounting to an inward FDI stock of 192 billion Euro by 2000 (DNB 2001). This makes the Netherlands the fifth largest recipient of FDI in the world (United Nations 2000) behind the US, the UK, China, and Germany, but ahead of any other small developed economy as can be seen in Table 1.2. Its relative success in attracting FDI therefore makes it an interesting example. The impact of FDI on the Dutch economy has been studied by Stubenitsky (1970) and more recently by Beers et al. (1999) and Wintjens (2001). They looked at the influence of FDI on trade flows, employment, technological development and innovation, economic growth, the environment, and linkages with local firms. Presently, however, academic studies on the determinants of Dutch inward FDI and the behaviour of foreign affiliates in the Netherlands are unavailable. We fill this gap with the present study.

To study the foreign business activities of MNEs in a small industrialised economy, three very important factors need to be analysed. First of all, the actual presence of foreign firms in a host economy. Questions related to this topic are, for example: Which firms have established an affiliate in this particular host economy? In which sectors do these affiliates participate? In which geographic locations are the affiliates present in a given 
economy? And, when did the foreign firms that are currently present in the host market start their activities?

Secondly, having established who is present in a particular host economy logically leads to an investigation into the reasons why foreign firms decided to establish an affiliate there. This results in a search for the different motivations companies have to conduct international activities. Why did they decide to start up an affiliate outside their home country? What macro- and micro-economic factors determine the choice for a particular host economy?

Answering these questions of who is present in a particular host economy and why, leads to a third factor that needs to be investigated: the behaviour of foreign activities in host economies. Have firms changed their activities after the first establishment and if so how? Do they limit their activities within the country's borders? Which factors might act as deterrents to future investments or expansions at the current site? Negative experiences in a host economy might reduce additional investments and could ultimately scare the affiliate out of the host location. Given the favourable impact of MNEs on the host economy, that would be an undesirable result. It is therefore important to know what the affiliates' future plans consist of.

The general research question guiding this thesis summarises all these questions and therefore states:

\section{What explains the entry and activities of foreign firms in a small economy?}

To seek answers to this question, this thesis is mainly empirical in nature. For the overall analyses we chose to investigate all currently established foreign firms in one particular small economy: the Netherlands. This choice is motivated by the country's relative success in attracting FDI. To analyse the presence of foreign firms in the Netherlands, we created a database - DutchInvest - with information on all foreign affiliates present in the Netherlands in 1996 (a description of the database is given in Appendix A at the end of this study). For the investigation into the reasons, activities, and behaviour of foreign affiliates we have specifically targeted the foreign-owned establishments in the Dutch electronics industry, using a questionnaire survey.

\subsection{The reasons for selecting the electronics industry}

Along with the increased volume of FDI flows over the last two decades, there have been substantial changes in the direction and composition of these flows (Andersson et al. 1996). In the 1970 s, FDI shifted away from natural resource extraction (minerals and ores) and basic manufacturing - both particularly important in developing countries (Dicken 1992) - towards high value-added production, which is critically dependent on access to modern technology and a skilled labour force. Three broad types of 
manufacturing industry appear to have an especially large MNE involvement (Dicken 1992):

1. Technologically more advanced sectors - for example pharmaceuticals, computers, scientific instruments, electronics, synthetic fibres

2. Large volume, medium technology consumer goods industries - for example motor vehicles, tyres, televisions, refrigerators

3. Mass-production consumer goods industries supplying branded products - for example cigarettes, soft drinks, personal care products, breakfast cereals

At the end of the $1990 \mathrm{~s}$, this is still true. The top 20 of MNEs presented in Table 1.3 shows that the world's largest firms are active in motor vehicles (General Motors, Ford Motor Company, Daimler Chrysler), (consumer) electronics (General Electric, Siemens AG, Sony Corporation), and food and beverages (Nestlé SA, Unilever).

In Chapters five and six of this thesis a thorough investigation is conducted of foreign business activity in one of these high MNE-involvement sectors: electronics. By paying particular emphasis to a high-tech sector, we are able to capture the reasons and behaviour of FDI in a dynamic, fast-changing environment with short product life cycles and heavy investments in research and development.

The electronics ${ }^{11}$ industry was chosen for several reasons. First of all, historically, continental Europe had strong competitive advantages in both chemical and electrical engineering (Dunning 1993). A series of innovations by Siemens and AEG (Germany) and Philips (the Netherlands) led to a competitive strength in this industry by the end of the 19th century. These firms' own foreign operations were market-seeking and primarily motivated by existing import barriers in target markets. Supplying foreign markets with exports was impossible, encouraging the establishment of local production units abroad. Additional motivations for investments included the need to reduce freight and production costs, the need to cater a specific market or special needs of customers, and the possibility and preference to internalise the market for a firm's competitive advantage. The presence of these large traditional electronics firms may have acted as an important determinant for both supplier and customer firms to locate near them by starting a foreign affiliate.

Secondly, electronics firms produce knowledge- and technology-intensive products. Studying foreign establishments in this sector enables us to capture the effects of foreign firms in a dynamic, turbulent environment with rapid communication grapevines, fast imitation, and heavy investments in R\&D. The innovation cycle in this industry is shortening rapidly ${ }^{12}$. Products are quickly outdated.

\footnotetext{
${ }^{11}$ The electronics sector consists of those products and systems that use electronic circuits handling small currents which incorporate 'active' components capable of modifying the flow of electricity (Dicken 1992).

${ }^{12}$ Hundreds of new electronic components are introduced into the market every month with almost as many being discontinued. Companies have neither the time nor the resource to research and evaluate every device that will be used in a final product, as they strive to beat the competition to market (Druce 2002).
} 
Table 1.3 The largest 20 MNEs in the world, 1998, ranked by foreign assets

(Sales in billions of US\$)

\begin{tabular}{|c|c|c|c|c|c|c|c|c|c|}
\hline \multirow[t]{2}{*}{ MNE } & \multirow[t]{2}{*}{ Industry } & \multirow[t]{2}{*}{ Country of origin ${ }^{1}$} & \multicolumn{2}{|c|}{ Assets } & \multicolumn{2}{|c|}{ Sales } & \multicolumn{2}{|c|}{ Employment } & \multirow{2}{*}{$\begin{array}{l}\text { TNI } \\
(\%)\end{array}$} \\
\hline & & & Total & Foreign & Total & Foreign & Total & Foreign & \\
\hline General Electric & Electronics & United States & 355.9 & 128.6 & 100.5 & 27.7 & 293000 & 130000 & 36.3 \\
\hline General Motors & Motor vehicles & United States & 246.7 & 73.1 & 155.5 & 49.9 & 396000 & n.a. & 30.9 \\
\hline Royal Dutch/Shell & Petroleum & Netherlands/UK & 110.0 & 67.0 & 94.0 & 50.0 & 102000 & 61000 & 58.0 \\
\hline Ford Motor Comp. & Motor vehicles & United States & 237.5 & n.a. & 144.4 & 43.8 & 345175 & 171276 & 35.4 \\
\hline Exxon Corp. & Petroleum & United States & 70.0 & 50.1 & 115.4 & 92.7 & 79000 & n.a. & 75.9 \\
\hline Toyota & Motor vehicles & Japan & 131.5 & 44.9 & 101.0 & 55.2 & 183879 & 113216 & 50.1 \\
\hline IBM & Computers & United States & 86.1 & 43.6 & 81.7 & 46.4 & 291067 & 149934 & 53.0 \\
\hline BP AMOCO & Petroleum & UK/United States & 54.9 & 40.5 & 68.3 & 48.6 & 98900 & 78950 & 74.9 \\
\hline Daimler Chrysler & Motor vehicles & Germany/United States & 159.7 & 36.7 & 154.6 & 125.4 & 441502 & 208502 & 50.4 \\
\hline Nestlé SA & Food/beverages & Switzerland & 41.1 & 35.6 & 52.0 & 51.2 & 231881 & 225665 & 94.2 \\
\hline Volkswagen & Motor vehicles & Germany & 70.1 & n.a. & 80.2 & 52.3 & 297916 & 142481 & 53.8 \\
\hline Unilever & Food/beverages & UK/Netherlands & 35.8 & 32.9 & 44.9 & 39.4 & 265103 & 240845 & 90.1 \\
\hline Suez-Lyonnais des Eaux & Diversified/Utility & France & 84.6 & n.a. & 34.8 & 12.9 & 201000 & 126500 & 45.6 \\
\hline Wal-Mart stores & Retailing & United States & 50.0 & 30.2 & 137.6 & 19.4 & 910000 & n.a. & 37.2 \\
\hline $\mathrm{ABB}$ & Electrical Equip. & Switzerland/Sweden & 32.9 & n.a. & 27.7 & 23.1 & 162793 & 154263 & 89.1 \\
\hline Mobil Corporation & Petroleum & United States & 42.8 & n.a. & 53.5 & 29.7 & 41500 & 22100 & 58.6 \\
\hline Diageo Plc & Beverages & United Kingdom & 46.3 & 27.9 & 12.4 & 10.5 & 77029 & 65393 & 76.7 \\
\hline Honda Motor corp. & Motor vehicles & Japan & 41.8 & 26.3 & 51.7 & 29.7 & 112200 & n.a. & 60.2 \\
\hline Siemens AG & Electronics & Germany & 66.8 & n.a. & 66.0 & 45.7 & 416000 & 222000 & 53.6 \\
\hline Sony corporation & Electronics & Japan & 52.5 & n.a. & 56.6 & 40.7 & 173000 & 102468 & 59.3 \\
\hline
\end{tabular}

Source: United Nations (2000). The transnationality index (TNI) is the average of the foreign share in assets, employment, and sales in a particular firm. It indicates the degree of internationalisation of the firm

${ }^{1} \mathrm{UK}=$ United Kingdom

$\mathrm{n} . \mathrm{a}=$ not available 
The mechanical typewriter, for example, had a life cycle of 35 years. Its electric successor lasted 20 years, and the current PC word-processing software is upgraded almost every six months (Kluge et al. 1996). These short product life cycles - for electronic products on average 4 to 7 years - forces firms in high-tech sectors to expand internationally very rapidly, even if they are young and comparatively small. If they do not expand, they risk losing the market opportunities even at home (Ayal and Izraeli 1997).

Thirdly, although the electronics industry is a highly capital-intensive, manufacturingbased industry, the production of goods in the electronics industry involves a lot of manual assembly and is therefore also relatively labour-intensive ${ }^{13}$. The overall influence of this industry on world employment is therefore considerable (Dicken 1992). In addition, electronics firms produce a wide variety of products ranging from radios and televisions to personal computers and from workstations to manufacturing-oriented semiconductors (memory chips and microprocessors). The influence of electronics products on both business and personal life therefore is large.

Fourthly, the electronics industry allows us to study many different modes of international investment. Ayal and Izraeli (1997) emphasise that multiple loci of production for high-tech products (apart from extensive licensing arrangements) are extremely rare. Usually international activities involve exports, sales offices, local assembly, or at most partial production of components. If foreign production occurs, it is often motivated by trade restrictions. The existence of trade barriers in the US and Europe, for example, has encouraged the international (tariff-jumping) expansion of particularly Japanese electronics firms. Huge MNEs dominate the industry. The top- 100 of the world's largest MNEs includes 16 electronics, electrical equipment, or computer companies. These firms are listed in Table 1.4.

Among them are many firms whose headquarters are located in the US or Japan. The European electronics industry has been under pressure due to an excessive concentration on the high-end segment of the market (concentrating on customer's special needs) and a lack of market-driven technological innovation (Joly et al. 1994). Although particularly the older European electronics firms (such as Philips and Siemens) are still important, they are loosing market share to mostly Japanese firms even in their home countries (Joly et al. 1994). The international activities of those non-European firms therefore clearly matter in European host economies. Most studies of the electronics industry have, however, been limited to Anglo-Saxon countries and Japan and the newly developing

\footnotetext{
${ }^{13}$ At the time of this study (1996-2000), the electronics industry was performing well, achieving satisfactory sales growth and profits, particularly in Europe and the US. However, during 2001 a serious downturn started (due to excess inventories and weakening demand (MacLallen 2001)), that was aggravated by the terrorist attacks in the US, on September 11, 2001. Many employees were fired (Reynolds 2001). Electronics Weekly estimated that over 200,000 jobs were lost in the global electronics industry in 2001 (Mayhew-Smith 2001). A recovery is not expected until the latter part of 2002 with the market gaining momentum again in 2003 (European Electronic Market Forecast 2001).
} 
Asian economies. Our focus therefore is on a small European economy to extend the existing knowledge of foreign activities in electronics.

Table 1.4 The world's largest electronics MNEs, ranked by employment, 1998

\begin{tabular}{|l|l|r|r|}
\hline Name & Country & Employment & Sales (billions of US\$) \\
\hline Siemens AG & Germany & 416000 & 66.0 \\
Hitachi Ltd & Japan & 331494 & 63.8 \\
General Electric & United States & 293000 \\
IBM & United States & 291067 \\
Matsushita Electric & Japan & 282153 & 100.5 \\
Philips & Netherlands & 233686 & 81.7 \\
Toshiba Corporation & Japan & 198000 & 63.7 \\
Fujitsu Ltd & Japan & 188000 & 33.9 \\
Sony Corporation & Japan & 173000 & 44.6 \\
ABB & Switzerland & 162793 & 43.3 \\
Motorola Inc. & United States & 141000 & 56.6 \\
Hewlett-Packard & United States & 124600 & 27.7 \\
Alcatel & France & 118272 & 31.3 \\
Ericsson LM & Sweden & 103667 & 46.5 \\
Electrolux AB & Sweden & 99322 & 23.6 \\
Canon Electronics & Japan & 79799 & 22.8 \\
\hline Source: United & & 14.5 \\
\hline
\end{tabular}

Source: United Nations (2000)

For the Netherlands in particular, it is obvious that the presence of one of the world's largest MNEs - Philips Electronics- has attracted foreign suppliers and competitors in the electronics industry to the Netherlands. Furthermore, the electronics industry is by far the industry with the highest re-exports in the Netherlands and the highest growth rate. In 1992, re-exports of electronic products took $55 \%$ of total Dutch exports in this sector. The Netherlands therefore is an important European distribution centre for electronics products (Minne 1997) ${ }^{14}$. In addition, from the DutchInvest database (Appendix A) it is clear that considerable foreign manufacturing investments have occurred in industrial and commercial machinery and computer equipment (SIC35) and electronic and other

\footnotetext{
${ }^{14}$ The most recent Macro Economic Outlook (CPB 2001a) has drawn attention to the fact that particularly over the last 10 years re-exports have grown considerably from $20 \%$ (1990) to almost $40 \%$ (2000) of total exports from the Netherlands. In 2000, the difference between imports and exports of goods destined for re-exports to the European continent equalled 9.7 billion Euro. This amount consists partly of transportation and trade costs, but also of value added for the Dutch economy. Given that less labour is involved, re-exports make a much smaller contribution to GDP than with locally produced export goods. Still, the influence of re-exports on the Dutch economy exists.
} 
electrical equipment and components (SIC36). Almost 29 percent of all foreign manufacturing establishments occurred in these sectors. In addition to the manufacturing establishments, several electronics sales offices, European headquarters, and electronicsrelated holdings have Dutch activities. Given their dominance in total investment, we therefore focus our analyses on this industry.

\subsection{Outline of the study}

In Figure 1.2 an overview of the study is provided. We consider both a macro-economic perspective - examining the determinants of the flows of FDI to the Netherlands as a whole - as well as a meso- and micro-economic perspective - looking at the individual establishments by foreign MNEs in the Dutch electronics industry. Chapter two introduces the Netherlands as a small country, discusses the economic structure, and the overall foreign investment position. We investigate how the locational attractiveness of the Netherlands for foreign firms has developed over time.

The main body of this thesis consists of four empirical chapters that all include a theoretical introduction. Chapter three provides a contextual analysis that gives insight into the particular economic development of the Netherlands and FDI. It discusses general statistics related to the inward FDI situation in more depth, focussing on the most important investing countries. Using OLS-regression, we investigate the macrodeterminants of FDI between 1987-1999, the period following the commitment to the Single European Market.

Chapter four investigates the patterns of agglomeration in Dutch inward FDI. The DutchInvest database allows us to analyse the presence and locational choice of foreign firms in the Netherlands. Insights from economic geography are combined with FDI theory to investigate the choice of a particular location within the Netherlands. A discrete choice logit model determines the factors that influence the choice between the Randstadarea and the rest of the Netherlands. A conditional logit model is estimated to determine the factors that influence the establishment of a foreign firm in one of the 12 provinces of the Netherlands.

Chapters five and six discuss the results of a questionnaire survey among foreign electronics firms conducted in autumn/winter 1999-2000. Chapter five analyses the determinants of inward FDI in the Dutch electronics industry in more detail. The results of the questionnaire are discussed within Dunning's OLI-framework, considering both locational determinants, internalisation issues, and ownership advantages. We relate the results to characteristics of the individual establishments, such as size, activity, age, parent location, and function, to find out the reasons for being in the Netherlands.

Chapter six is then mainly concerned with the empirical analysis of the sales focus of foreign activities in the electronics industry in the Netherlands. Multinomial and binomial logit models are used to investigate the differences in characteristics between firms that supply the Dutch market from their local establishments and firms that take a broader 
view and focus their sales on Europe. The results help us to determine the salesbehaviour of the foreign affiliates.

Finally, an appraisal of the results is given in Chapter seven. It combines all the results presented in the Chapters three till six and considers the implications of these findings. Conclusions are drawn with regard to the questions and hypotheses posed in the individual chapters. Chapter seven also states the most important strengths and weaknesses of the study and gives recommendations for further research.

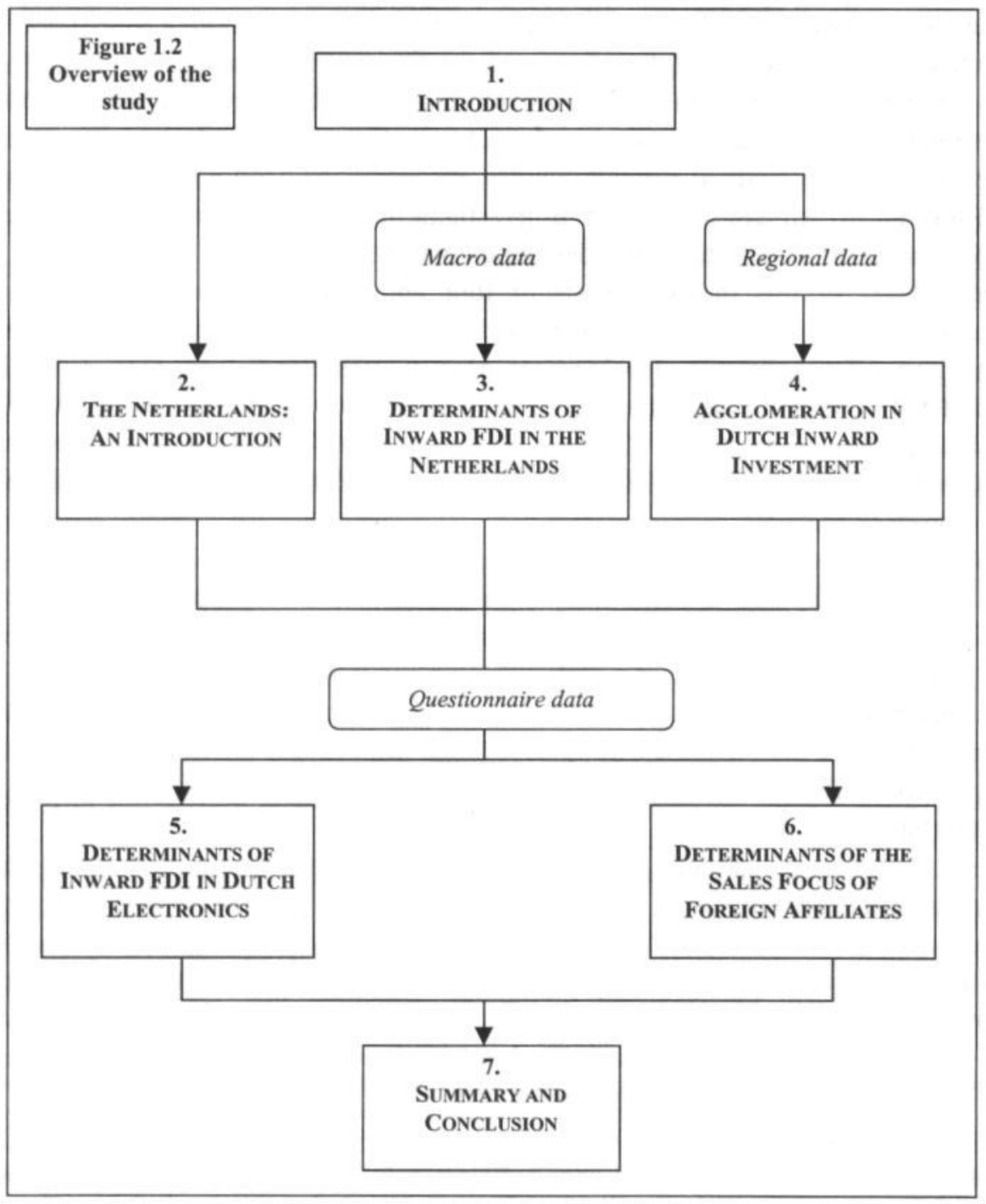




\section{LOCATIONAL ADVANTAGES OF THE NETHERLANDS: AN INTRODUCTION}

\subsection{Introduction}

Though small in size (in terms of population and geographical area) the Netherlands has a rather unique investment position, both as a home country of outward investors and as a host for inward FDI activity. This FDI activity can be studied within the eclectic paradigm of international production (Dunning 1980, 1988a, 1993, 1995, 2000, 2001) ${ }^{1}$. In this framework, firms possess three key sets of advantages relating to their ability to become MNEs: ownership, internalisation, and location advantages. Ownership (O) advantages are factors unique to the nature or nationality of the ownership of a firm and are referred to as the "why" of multinational activity (Dunning 1988a). Ownership advantages relate to the multinational's ability to compete in foreign markets and are based on unique country-, industry-, and firm-specific variables, such as a certain technology. Internalisation (I) advantages of firms determine whether the firm will organise international transactions efficiently through markets or through internal (hierarchical) means and address the "how" of involvement (Dunning 1988a).

MNEs try to use their O-advantages in conjunction with the immobile natural or created assets that are location- and country-specific (Narula and Dunning 1999). These location (L) advantages affect the choice of a foreign country for multinational operations and are referred to as the "where" of production (Dunning 1988a). In the absence of favourable locational conditions in a host market, a firm would prefer to serve the foreign market by exports from a domestic base rather than by establishing an affiliate in the host economy. Important location advantages include the distribution of natural and created resources, international communication and transportation costs, investment incentives and disincentives, trade barriers, infrastructure, and differences or similarities in culture, language, and business attitudes.

To understand why so many foreign investors chose the Netherlands, in this chapter we introduce and analyse the locational factors that are potential determinants of the attractiveness of the Netherlands as a host for foreign investments. These factors will be empirically tested in subsequent chapters. We will begin by introducing some characteristics of the Dutch economy. We will consider the crucial importance of the openness for trade and the contribution of the former colonies. After that, we will discuss

\footnotetext{
${ }^{1}$ Dunning's Eclectic Paradigm of international production is used to explain the international activities of producers of both goods and services (Dunning 1993, 2001). One recent example of an application of the Eclectic Paradigm to services is O'Gorman and McTiernan (2000) who study the Irish hotel industry.
} 
the extraordinary economic recovery of the Dutch economy since the mid-1980s (known as the "Dutch miracle"). One of the important events in the economic history of the Netherlands was the establishment of the European Economic Community (EEC). The Netherlands was among the first to acknowledge the importance and potential benefits of European unification. We separately discuss the history and importance of European integration for the locational determinants in the Netherlands. Subsequently, the outward FDI position of the Netherlands is considered. The presence and activities of large MNEs influences the attractiveness of the Netherlands. Finally, the overall position of the Netherlands as a host of foreign direct investment is discussed. We will introduce some of the large investors in the Netherlands. While we cover data from the early 1960s onwards, most attention is focussed on the late 1980s and 1990s, a period not much investigated and comprehensively summarised in previous published work (see Nieuwkerk and Sparling 1985, Loeve 1986, Zanden 1997, Beers et al. 1999, Wintjens 2001).

\subsection{The importance of trade in the Dutch economy}

The Netherlands is located in Europe, at the estuaries of two great rivers, the Rhine and the Meuse, with borders to Germany in the east, Belgium in the south, and the North Sea in the west and north (see Figures 2.1 and 2.2). In Chapter one, the Netherlands was introduced as a relatively small, industrialised country. Its economy is generally considered to be open, strong, and dynamic. Due to its favourable location at the North Sea, the Netherlands has always been an important trading nation and major distribution centre for continental Europe (Dillen 1970, Hoesel and Narula 1999, Vries and Woude 1995, Zanden 1993, 1997). As early as the seventeenth century (a period known as the "Golden Age", broadly stretching from 1550-1700), the Dutch developed strong trading and merchandising skills resulting in great economic prosperity. The Dutch East India Company (Verenigde Oostindische Compagnie or $\mathrm{VOC}^{2}$ ), established in $1602^{3}$, benefited from a monopoly on the trade in the East Indies. The VOC traded spices like nutmeg, cloves, cinnamon, and pepper, and other luxury consumer products such as tea, silk, and Chinese porcelain. Its purpose was not only trading, the VOC also had to fight the enemies of the Republic and prevent other European nations (particularly Portugal, England, and France) from entering the East India trade. Due to their dominance at sea, the Dutch managed to conquer countries in the "west" (particularly what is now

\footnotetext{
${ }^{2}$ The VOC is often considered the first multinational enterprise given that it had establishments in several Asian countries. However, considering that the shareholders had no influence, supervision of the board (De Heren Zeventien) was non-existent, and the fact that the VOC was partly founded for military purposes, it had an extraordinary position that differs significantly from present MNEs.

${ }^{3}$ Four hundred years after the establishment of the VOC on March $20^{\text {th }} 1602$, its history is the subject of many exhibitions and activities in the Netherlands in 2002.
} 
Indonesia) and use the trade in the colonies' resources (sugar, tobacco) for its own economic development.

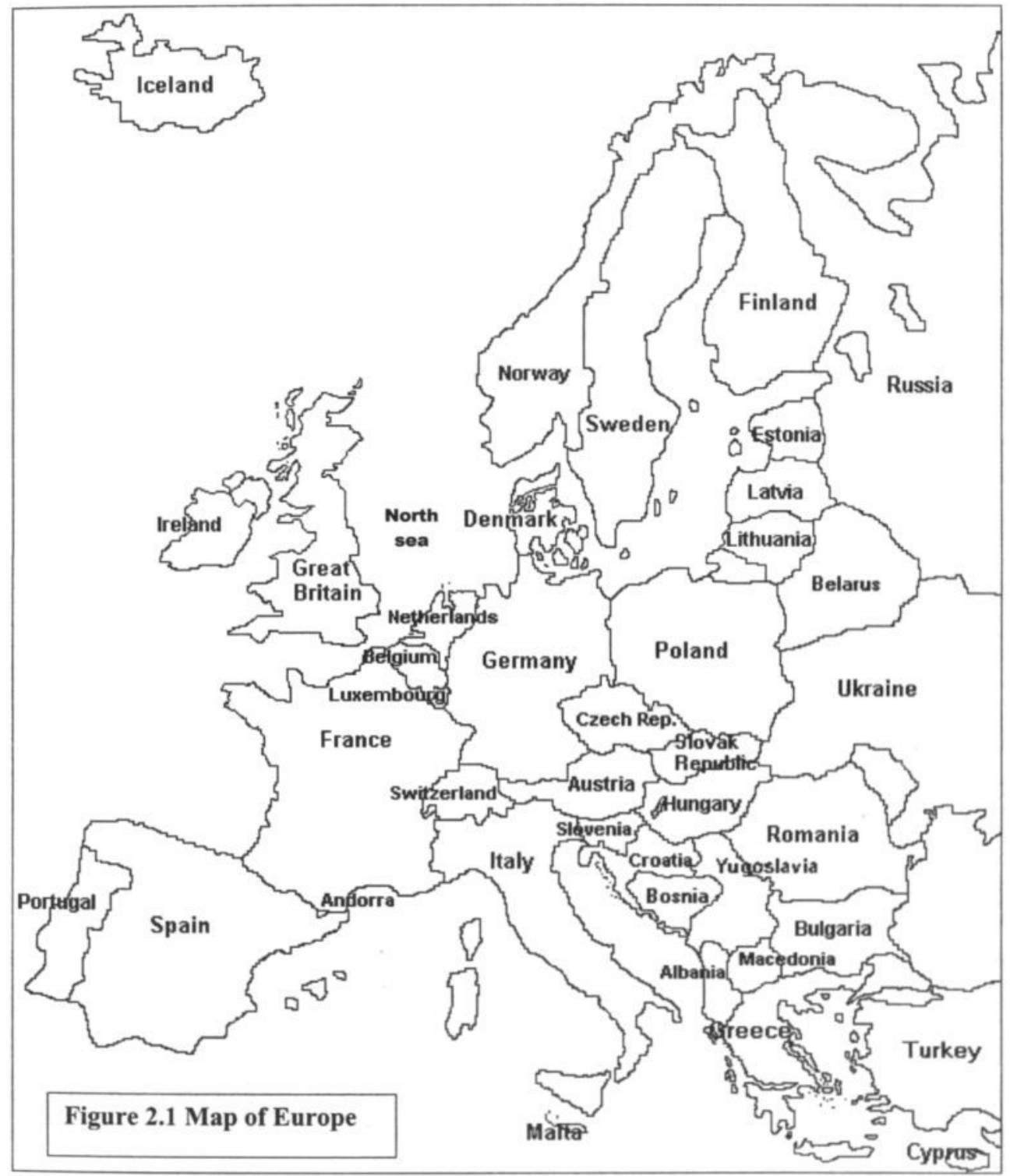




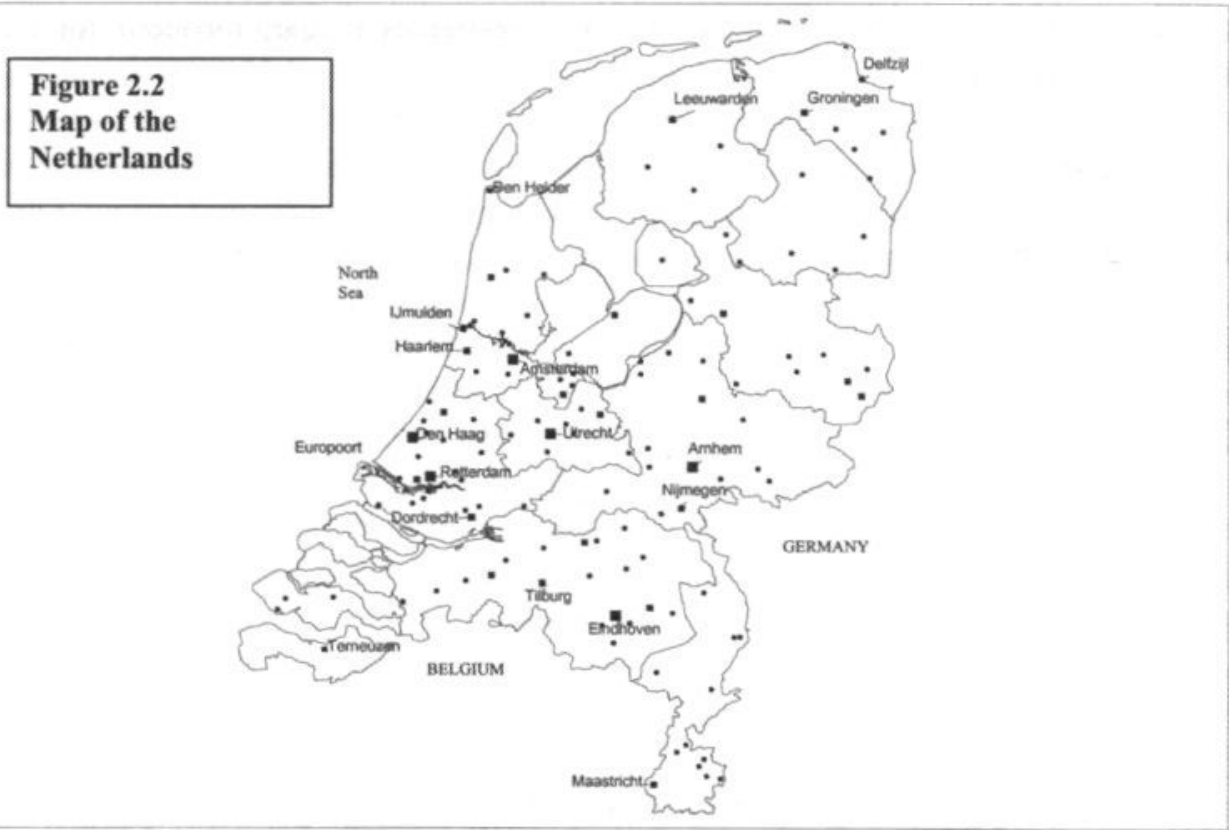

Even today, the importance of trade for Dutch economic prosperity remains. The modern Dutch economy is recognised for its international competitiveness and is driven by the winds of trade (Hoesel and Narula 1999). Although it is quite common for a smaller country to be more dependent on international trade than its larger counterparts, the ratios of exports and imports to GDP are extremely high for the Netherlands (as indicated in Table 1.2 in Chapter one). Half of what the country produces is destined for foreign markets, therefore making the economy highly dependent on cross-border exchange and also highly vulnerable in case of international economic slowdown ${ }^{4}$. It should be noted that some of the exports include re-exports and transit of goods that are not produced in the Netherlands (Hoesel and Narula 1999) and that their share in total exports is increasing rapidly (CPB 2001a). But even without those transhipments and entrepotactivities, exports are still considerable. The economic success of the Netherlands thus greatly depends on how well Dutch products and services can be sold in an increasingly competitive international market.

Dutch exports are mainly composed of oil and chemicals, machinery, and transport equipment (OECD 2000). These products originate in the sectors and MNEs that

\footnotetext{
${ }^{4}$ This vulnerability was particularly clear at the end of $2000 / 2001$. After several years with rapid expansion and little inflationary pressure, the performance of the Dutch economy has deteriorated markedly since early 2000 . The downturn appears to have been primarily due to external factors. The abrupt slowdown of the US economy and the fall in global stock markets negatively affected the Dutch economy through declining household and business confidence. These negative effects more than offset the impact of the introduction of a major tax reform at the beginning of 2001 (OECD 2002).
} 
dominate present-day Dutch industry. At the same time, the nation is Europe's largest exporter of agricultural products (fruits, vegetables, and flowers). International services such as transportation, construction, and finance are the fastest growing industries in the trade sector (Beije and Nuys 1997). By far the most important destinations for Dutch exports are the Euro-zone countries. The large majority of Dutch exports stay on the European continent. Its neighbours Belgium and Germany together with France account for almost 50 percent of its export market as can be seen from Table 2.1.

Table 2.1 Most important Dutch trading partners

(Several years, percentage share in total flow)

\begin{tabular}{|l|l|r|r|r|l|l|r|r|r|}
\hline \multicolumn{2}{|l|}{ Export destinations } & 1980 & 1990 & 1999 & \multicolumn{2}{|l|}{ Import sources } & 1980 & 1990 & 1999 \\
\hline 1 & Germany & 21.5 & 32.3 & 26.6 & 1 & Germany & 20.2 & 35.0 & 18.4 \\
2 & Belgium \& & & & & 2 & Belgium \& & & & \\
& Luxembourg & 10.8 & 17.1 & 12.2 & & Luxembourg & 10.5 & 19.1 & 9.6 \\
3 & France & 7.6 & 13.1 & 10.8 & 3 & US & 8.0 & 10.7 & 9.5 \\
4 & UK & 5.7 & 11.9 & 10.5 & 4 & UK & 7.4 & 11.2 & 9.4 \\
5 & Italy & 4.2 & 7.8 & 5.9 & 5 & France & 6.1 & 10.5 & 6.2 \\
\hline
\end{tabular}

Source: CBS $(1981,1992,2001 b)$

For imports the patterns are similar, although the US is a much more important trading partner now with almost one tenth of all imports originating there. Belgium, Luxembourg, and Germany account for nearly 30 percent of all imports. The most important imports include machinery, food, oil, and chemicals (OECD 2000). It is interesting to note that although some fluctuations in the composition of exports and imports did take place, grosso modo the relative importance of the goods composition has not changed much over the last decades. This also implies that relatively knowledgeextensive industries such as food (cheese), beverages, and tobacco as well as primary commodities (such as flowers, eggs, milk cream, and tomatoes) continue to play an important role in the Dutch economy (Beije and Nuys 1997, Brouthers and Brouthers 1997, Hoesel and Narula 1999).

This pattern is confirmed when looking at the sectoral composition of the Dutch economy. Table 2.2 indicates that for the Netherlands, the primary sector (especially agriculture and natural gas $\left.{ }^{5}\right)$ contributes somewhat more to the country's GDP (3.2 percent of total) than in the other countries listed. Furthermore, although the services sector is not exceptionally large for an industrialised economy, it does generate a

\footnotetext{
${ }^{5}$ The presence of bituminous minerals (oil and natural gas) on Dutch soil (particularly in the Northeast: Groningen, Drenthe) was established long before the Second World War. However, successful exploration only commenced in the $1950 \mathrm{~s}$ and $1960 \mathrm{~s}$. The Netherlands exports part of the gas it produces or purchases (from the Russian company Gazprom). Germany, Belgium, France, Italy and Switzerland are long-standing customers, and billions of cubic metres of gas are dispatched to these customers every year.
} 
relatively large number of jobs compared to most of the other industrialised countries. Seventy-five percent of total Dutch employment takes place in services.

Table 2.2 Sectoral composition in several large FDI hosts

\begin{tabular}{|l|r|r|r|r|r|r|}
\hline & NL & Belgium & Germany & France & UK & US \\
\hline Sectoral GDP (\%) & & & & & & \\
Primary & 3.2 & 1.5 & 1.3 & 3.2 & 1.3 & 1.7 \\
Secondary & 27.5 & 28.7 & 32.1 & 26.1 & 28.8 & 26.1 \\
Tertiary & 69.3 & 69.8 & 66.6 & 70.8 & 69.9 & 72.2 \\
Sectoral labour division (\%) & & & & & & \\
Primary & 3.3 & 2.4 & 2.8 & 4.4 & 1.7 & 2.7 \\
Secondary & 21.7 & 26.0 & 34.5 & 25.2 & 26.5 & 23.6 \\
Tertiary & 75.0 & 71.5 & 62.6 & 70.4 & 71.8 & 73.7 \\
\hline
\end{tabular}

Source: OECD Economic Surveys, various issues

\subsection{The "Polder"-model}

In 2000 , for the fourth year in a row, the Dutch economy grew by almost four percent (CBS 2001). Table 2.3 shows that the average growth rate from 1994-1998 has been 3.2 percent per year, far higher than the European Union average $(2.5 \text { percent })^{6}$. This economic growth has been accompanied by a significant rise in the creation of new jobs. The favourable economic climate paved the way for employment expansion by no fewer than 150,000 jobs. Unemployment has fallen to 3.2 percent in 1999 , a low rate by international standards (Ministry of Economic Affairs 2001, OECD 2000) ${ }^{7}$.

\footnotetext{
${ }^{6}$ The statistics discussed in this section cover the period preceding the questionnaire study conducted for Chapter five of this thesis. However, the economic position of the Netherlands has deteriorated markedly since early 2000. In 2001, for the first time since 1988, GDP growth in the Netherlands (1.1 percent) lacked behind the euro-zone average (1.7 percent (CPB 2002a, 2002b)). Inflation has risen sharply to 5.1 percent in 2001, compared to 2.5 percent for the Euro-zone (DNB 2002). This increase is partly due to tax reforms but also to increasing labour costs and high import prices. The government balance improved to a surplus of 0.6 percent of GDP in 2001 (OECD 2002). For 2002 and 2003, GDP is expected to grow by 1.5 percent and 2.5 percent respectively, still lacking behind the euro-zone average, mainly due to a sharp loss of competitiveness as a result of the strong increase in unit labour costs due to the tight labour market (CPB 2002a).

${ }^{7}$ In 2000, the unemployment rate fell further to 2 percent, about 140.000 people (DNB 2002). Even though the overall economic position has deteriorated, unemployment has not increased. Employers tend to hold on to their employees in the tight labour market, anticipating an economic recovery (a phenomenon known as labour hoarding). As a result, labour productivity is declining (DNB 2002). This is a worrisome development. For 2002 and 2003, employment is expected to grow with 0.5 percent annually (particularly in public and non-commercial services). Since labour supply will grow at an expected rate of 1 percent annually, for the first time since 1993 unemployment will grow (particularly in industry, trade, transportation and communication). The unemployment rate is forecast at 3.75 percent in 2002 and 4.5 percent in 2003 (CPB 2002a).
} 
Table 2.3 Economic indicators

\begin{tabular}{|l|r|r|}
\hline & Netherlands & European Union \\
\hline Economic growth (1994-98 average) & $3.2 \%$ & $2.5 \%$ \\
Growth in employment (1994-98 average) & $2.1 \%$ & $0.4 \%$ \\
Inflation (1998) & $2.1 \%$ & $1.75 \%$ \\
Budget deficit (1998) & $0.7 \%$ & $1.75 \%$ \\
\hline
\end{tabular}

Source: http://www.minez.nl/aep/publications/rapports/factshen.htm, retrieved 5/4/2001

The Netherlands is characterised by political stability. The current Dutch government is a "Purple"-coalition between social democrats (PVDA), liberals (VVD), and a small left libertarian party (D'66) ${ }^{8}$. During its first term of office (1995-1998) it continued the policies of previous governments (Lubbers I, II, and III) and strongly emphasised the need for employment expansion. The efforts to create more jobs were successful. Employment rose by an average of 2.1 percent per year (particularly in services and the temporary employment branche). Employment growth was far higher than the average increase in employment in the European Union ( 0.4 percent) and the United States (1.7 percent). From 1989 to 1998 , the working population increased 22 percent, with 1.2 million people (Ministry of Economic Affairs 2001).

This extraordinary performance - also known as the "Dutch miracle" - sharply contrasts the "Dutch disease"10 or "Hollanditis" from which the Dutch economy suffered in the early 1980s (Ministry of Economic Affairs 2001). The internationally renowned "Polder"-model (consensus-model) is often seen as the secret behind the recovery and success of Dutch socio-economic policy. The key to this model is the widely supported agreement between employers, unions ${ }^{11}$, and the government to strive for wage moderation in exchange for shorter working hours. The unique feature of this model lies in the constructive dialogue between the three parties.

\footnotetext{
${ }^{8}$ In 1994, these three parties joined forces resulting in the first government without the Christian democrats (CDA) since 1918 (with the exception of the WWII period 1940-1945). The combination of liberal blue with social-democratic red provided the name by which the coalition has been known since 1994: purple (Paars). The former opposites got along so well that they prolonged the coalition after the 1998 elections. Prime minister during both governments was Wim Kok.

${ }^{9}$ Some of this increase can be attributed to a rise in female labour participation that has always been much lower in the Netherlands than in most European countries.

${ }^{10}$ After the second world war, the Netherlands quickly joined Europe's economic revival, and in 1959 received a boost from the discovery of large gas reserves off its northern coast. Gas fuelled a massive expansion of public spending, especially the construction of a generous welfare state. By pushing up the exchange rate, gas also helped to eat away Dutch competitiveness. The two oil shocks of the 1970s made matters worse, especially when the government responded with reflation rather than retrenchment. The Dutch Disease, "welfare without work", resulted. The budget deficit touched over 7 percent of GDP in 1982 (The Economist 2002).

"In the Netherlands, the employers and the unions are generally referred to as the 'social partners' which emphasises their collaborative efforts.
} 
The basis for the recent good economic performance was laid in the early 1980s, when policy focused on restoring the stagflating Dutch economy. Following the two oil crises (1973-4 and 1978-9), the recession (1981-3) was more severe in the Netherlands than in other OECD countries. During this period, 100,000 jobs were lost every year, partly due to the sharp rise in labour costs ${ }^{12}$. Furthermore, public finances had got completely out of hand and inflation reached unacceptable levels (Ministry of Economic Affairs 2001). Government, employees, and employers realised that drastic changes were needed to cure the "Hollanditis" and restore economic health.

Since then, three important changes of policy have radically altered the Dutch economy. The first new policy was the emphasis on controlling public spending in order to reduce the budget deficit and taxes on businesses. Sound public finances helped to bring down inflation and interest rates, facilitated by linking the Dutch guilder to the German mark in the early 1980s (Ministry of Economic Affairs 2001), which enhanced confidence in the guilder. The tax cuts contributed to the second important new policy, wage moderation. In 1982 employers and trade unions signed the Wassenaar-agreement aimed at reducing unemployment by moderating wage demands in exchange for shorter working hours and job security (Steffen 1998).

The third new policy introduced in the early 1980s involved a thorough overhaul of the social security system. This system caters for people who cannot support themselves as a result of long-term illness, unemployment, or old age ${ }^{13}$. Most benefit levels were reduced from 80 percent to 70 percent of the last-earned salary. The statutory minimum wage was frozen for a decade, with the result that benefits, too, lagged behind the average wage increases (Ministry of Economic Affairs 2001).

\subsection{Additional economic reforms in the Netherlands}

In the 1990 s, it was recognised that although the Dutch economy was recovering due to the effective social and economic policies, more changes were needed to create a sustainable increase in output and employment and to remain internationally competitive in world markets. Alebeek et al. (1997) identified six important barriers that still remained to be tackled. Two of them - lack of incentives to create and seek jobs and restrictive land designation procedures - directly reduce output. The other four - lack of competition, inflexible work and compensation rules, obstacles to new business development, and weak corporate governance - hinder innovation and therefore indirectly reduce output. The existing reforms were therefore supplemented by measures

\footnotetext{
${ }^{12}$ Several other countries, such as Sweden, suffered from similar problems (Andersson et al. 1996).

${ }^{13}$ Particularly the disability fund (the Wet ArbeidsOngeschiktheid: WAO, established July $1^{\text {st }}$, 1967) was used by employers and unions as a relatively cheap way to discard of excess labourers without firing them (which would result in a much sharper income drop for the employee). This "abuse" was possible because no clear description of the disabilities allowing for the benefits were given. As a result, over half a million people were receiving benefits from the fund by 1975 (instead of the anticipated maximum of 200,000).
} 
aimed at strengthening the overall economic structure to improve the operation of markets for goods, services, capital, and labour. These measures could result in strengthened (international) competitiveness.

A major step towards improving the operation of goods markets was the introduction of the Competitive Trading Act on 1 January 1998, which brought Dutch competition rules in line with those of the European Commission. The Netherlands Competition Authority (NMa) was created to implement and enforce the act.

Furthermore, the government is encouraging innovation, especially in the field of information and communications technology. On top of providing subsidies, it increasingly brings researchers, companies, and venture capital together. The Twinning Concept, for example, brings potential ICT-entrepreneurs and young companies into contact with experienced managers, coaches and venture capital (Ministry of Economic Affairs 2000). In addition, new businesses now have to meet fewer requirements upon establishment encouraging new start-ups with innovative ideas.

Although unemployment has fallen to around 3.25 percent in 1999 (OECD 2000), more flexibility in the labour market is still needed (Bolkestein 1999, OECD 2000). While Dutch labour market regulations offer solid protection for individual workers, they dampen economic growth (Alebeek et al. 1997). Moreover, the tight labour market results in inflationary pressures (see Table 2.3) that may result in a loss of international competitiveness (OECD 2000). Efforts are therefore made to increasing educational opportunities for long-time unemployed (to enhance their employment prospects) and to stimulate flexible jobs. The authorities try to reintegrate the unemployed in the active labour market within 12 months after loosing their job using "personal plans" (OECD 2000). Attempts are also made to make the wage formation process more flexible and responsive to local conditions and individual skills level (OECD 2000) ${ }^{14}$.

Improving the functioning of the labour market is also one of the major reasons for the comprehensive income tax reforms in $2001^{15}$. Tax rates on labour income are reduced. Incentives to enter the active labour market are strengthened by reducing replacement rates, in particular at the minimum wage level, through the substitution of the employed person's allowance with a higher earned income tax credit (or income rebate) without phase out range. In addition, the conversion of the standard tax allowances into individual tax credits is expected to remove the current disincentives for non-working partners from entering the labour market (OECD 2000).

Securing economic prosperity and international competitiveness also requires investment in space and infrastructure. Within the limits of a small and densely populated country

\footnotetext{
${ }^{14}$ OECD (2002) stresses again that improving the functioning of the labour market should be a top priority. Particularly the large pool of "inactives" - working-age benefit recipients not seeking a job remains a weak point of the economy.

${ }^{15}$ The major tax reforms (which include a shift from direct to indirect taxes) resulted in a sizeable one-off boost to disposable income. Due to the increase in the VAT rate and environmental taxes, HCIP inflation has risen rapidly, peaking at 5.0 percent (year-on-year) in October 2001 (OECD 2002). High inflation rates also reflect the pass-through of rapidly rising labour costs and increasing import prices.
} 
such as the Netherlands (where population density amounts to on average 468 people per $\mathrm{km}^{2}$ in 2000), sufficient space needs to be found for industrial estates. Furthermore, infrastructure must satisfy the increasing need for mobility (and traffic jams, currently one of the largest problems, should be prevented), particularly in the Randstad ${ }^{16}$ where a lot of economic activity is concentrated. Money and jobs flow to the Randstad for two important reasons. Rotterdam and the Europoort are strategically located at the North Sea, at the estuaries of the Rhine and the Meuse. It is the import-export point for Germany's industrial heartland. Furthermore, together Schiphol Airport and the Rotterdam harbours make the Randstad an excellent starting point for international transportation, both within Europe and worldwide. Therefore, to preserve the Netherlands' role as a gateway to Europe, the government is investing in the modernisation and expansion of Schiphol Airport. In addition, the port of Rotterdam is building an extra deep-water jetty and eight new container terminals. To facilitate additional transportation to Germany a new railway link with the rest of Europe (the Betuwe-lijn between Rotterdam and the German border) is created.

\subsection{European integration}

Given the importance of trade for the Dutch economy, the Netherlands was among the first countries to acknowledge the need for economic co-operation after World War II. The war (1939-45) had left chaos and destruction in Europe. To create an economic revival and rebuild Europe, in 1947 the US Congress passed The Marshall Plan, a US\$ 13 billion aid package. To coordinate and carry out this plan, the sixteen-country Organisation for European Economic Cooperation (OEEC) ${ }^{17}$ was established (Pelkmans 1997). The OEEC also sought to improve currency stability, combine Europe's economic strengths, and improve its trade relations by forcing the removal or widening of small countries' quota restrictions (Milward 1992). In the case of the Netherlands this meant opening up protected manufacturing industries - such as iron and steel products, agricultural machinery, aluminium, synthetic fibres, fertilisers, plastics, telephones, cars, and lorries - for foreign imports while its own exports - which were mostly agricultural products - scarcely benefited (Milward 1992). On top of severe balance of payments problems and the need to develop a more sophisticated industrial and export structure that was not dominated by agricultural products, the Netherlands had no choice but to strive for low(er) European tariffs and increasing economic cooperation.

\footnotetext{
${ }^{16}$ The Randstad - literally rim-town - is a circle of cities in the western Netherlands surrounding a "green heart" of meadows and lakes. Nearly seven million people live in this conurbation that starts from Amsterdam in the north, runs down the western shore to The Hague, the Europoort and Rotterdam and then loops back to Utrecht (see Figure 2.2).
}

${ }^{17}$ By 1960, the OEEC becomes the Organisation for Economic Cooperation and Development (OECD). 
On January $1^{\text {st }}, 1948$ a first significant step was made. The custom convention ${ }^{18}$ between Belgium, Luxembourg, and the Netherlands (the Benelux) entered into force. Shortly after, in 1951, the Six - Belgium, France, Germany, Italy, Luxembourg, and the Netherlands - established the European Coal and Steel Community (Welford and Prescott 1996). Their continued efforts towards further unification and greater efficiency resulted in the "Treaties of Rome" in 1957 when the Six established the European Atomic Energy Community (Euratom) (Pelkmans 1997) and the European Economic Community (EEC) (Griffin and Pustay 1999).

The initial objectives of the EEC were (Bennett 1997, Pelkmans 1997):

- Elimination of customs duties between member states,

- Establishment of an external common customs tariff,

- Introduction of a common policy for agriculture and transport,

- Creation of a European Social Fund,

- Establishment of a European Investment Bank,

- Development of closer relations between member states.

The first steps towards the total abolition of custom duties and quota within the EEC were conducted in 1959, resulting in the total elimination of all internal tariffs by 1967 (Mark I integration). At that time, a common external tariff was imposed, which moved the EEC from a free trade agreement to a customs union. By then, the name had changed to the European Communities (EC) ${ }^{19}$.

Other European countries acknowledged the benefits of economic cooperation as well. In 1959, seven countries (Austria, Denmark, Norway, Portugal, Sweden, Switzerland, and the United Kingdom) decided to establish the European Free Trade Association (EFTA), going into force in 1960. Many of those countries joined the EEC in the following two decades. In 1973, Denmark, Ireland, and the United Kingdom joined the EC. In 1980, Greece became the $10^{\text {th }}$ member of the EC, followed by Spain and Portugal in 1986. In 1995, Austria, Finland, and Sweden joined ${ }^{20}$ (Welford and Prescott 1996). Together those 15 countries make up the world's biggest market, with a GDP of US\$ 8.4 trillion in 1996, a fifth more than America's (Carr 1996), and a combined population of 372 million people (Griffin and Pustay 1999).

Two important events for the EC occurred at the end of the 1970s. The formation of the European Parliament was an attempt to bring democracy into the governance of the EU. The establishment of the European Monetary System (EMS) resulted in linking the

\footnotetext{
${ }^{18}$ Within a customs union, the participating countries remove all trade barriers (as in a free trade area) and also have a common external policy on international trade with non-members (Welford and Prescott 1996).

${ }^{19}$ The name signals the combination of the EEC, ECSC, and EURATOM, three European communities. However, unofficially, the EC is often addresses as the European Community.

${ }^{20}$ The EFTA is then reduced to Norway, Switzerland, and Iceland (that joined EFTA in 1970). Several other countries have applied for European Union membership. Fast track applicants include Hungary, the Czech Republic, Poland and Estonia. Other applicants include Slovak Republic, Latvia, Lithuania, Romania, and Bulgaria. Turkey is another candidate.
} 
individual national currencies. The EMS goal was to stabilise the exchange rates between members so that currency fluctuations could not replace tariffs as a way to discriminate against trade. However, it was evident that the EC needed more than the elimination of tariffs to achieve economic growth. Europe needed to be one market but a variety of nontariff barriers was keeping it from being so and from fully enjoying the expanded market size. Therefore the single market concept was developed and given force in 1986, when the Single European Act was signed. The aim was to remove all remaining fiscal ${ }^{21}$, physical $^{22}$, and technical barriers ${ }^{23}$ to create a virtuous circle of growth for the EC, its member states, and individual firms (Dicken 1992). The target date for implementation of those changes was December $31^{\text {st }}, 1992$.

Still not content with the economic integration envisaged in the Europe 1992 program, the EC leaders met in Maastricht, the Netherlands in December 1991 and approved the Treaty of Maastricht (Griffin and Pustay 1999). This Treaty had two goals: political union and monetary union. It also resulted in a name change to the European Union (EU) by November 1993. The EMS system thus gave way to a new monetary order (EMU) resulting in the Euro, the single European currency that came into effect on January $1^{\text {st }}$, 1999. Eleven of the 15 EU-member countries were prepared to join the monetary union on January $1^{\text {st }}$, 1999. Those not participating in the new Euro are the United Kingdom, Sweden, and Denmark (by their choice) and Greece (not ready) ${ }^{24}$. The Euro became a physical reality on January $1^{\text {st }}, 2002$ with twelve countries (Greece managed to join the EMU on January $\left.1^{\text {st }}, 2001\right)$ introducing the Euro coins and notes. The Euro is being administered by the European Central Bank (ECB) which was established by July $1^{\text {st }}$, 1998. The ECB is responsible for setting monetary policy and managing the exchange rate system for all of Europe since January $1^{\text {st }}, 1999$. Since the launch of the EMU, exchange rate risks within the Euro-zone have disappeared and differences in costs and prices in different countries have become more transparent. This will strengthen the integration of the European market, and improve the efficiency of internationally operating companies.

\footnotetext{
${ }^{21}$ European countries rely on value-added taxes (VAT) as a primary source of revenue. VAT needed to be harmonised to reduce the incentive for EU residents to travel to countries with lower VAT to purchase goods (Griffin and Pustay 1999).

${ }_{22}$ In 1990, France, Germany and the Benelux countries signed the Schengen-Agreement, abolishing passport controls at their common borders, encouraging the free flow of people. Most other EU countries followed, with the exception of Ireland and the United Kingdom (Griffin and Pustay 1999).

${ }^{23}$ Differing national product standards restricted trade because manufacturers had to either abandon certain markets or modify their products to meet members' conflicting regulations (Griffin and Pustay 1999).

${ }^{24}$ To be allowed to join, strict guidelines for convergence of the EU-economies were designed (Griffin and Pustay 1999). Inflation should not be more than 1.5 percentage points above the average of the three lowest inflation rates in Europe. The long-term interest rate should be no more than 2 percentage points above the average of the three lowest. The government budget deficit should be no more than 3 percent of GDP and the stock of public debt should not exceed 60 percent of GDP. The exchange rate should stay within the normal fluctuation margins. Greece failed to meet those criteria in 1999.
} 
After the decision to complete the Single European Market, the EU attracted greatly expanded FDI from various directions (Andersson et al. 1996, Barrell and Pain 1999). The removal of barriers to trade and capital within the EU has changed the permeability of national borders and hence the locational advantages of member states and the Union as a whole. Furthermore, Non-European firms concerned about the possibility of a closed regionalism (Fortress Europe) could be expected to increase their European presence to secure market position by tariff jumping FDI (Dunning 1992). The unified market would furthermore give foreign firms the possibility to benefit from scale and scope opportunities inside Europe and thus facilitate competitiveness and growth in other global markets (Tulder et al. 2001). The completion of the Single Market also resulted in a major restructuring, rationalisation, and streamlining of MNE activities in Europe due to possible intra-regional product and process specialisation (Dunning 1992, Tulder et al. 2001). With the free flow of goods and services it is no longer necessary to have activities in each individual EU-state. Firms can choose to serve all EU-markets from one location (Tulder 1999).

In general, economic integration offers a means by which small states may increase their internal stability by reducing external uncertainty through closer trade links and greater economic interdependence with neighbouring states. Membership of free trade areas and trade blocks therefore counteracts the adverse scale effects of small size by extending their domestic market as well as improving their terms of trade (Armstrong and Read 1998). Overall, it is expected that large European firms (particularly those that have established a pan-European presence) would by virtue of their size be in the best position to capitalise on the benefits of scale and efficiency (Tulder et al. 2001). However, the launch of the EMU and new technological developments also make it easier for small and medium-sized businesses to operate beyond their national borders. Growth inside Europe can be realised by scale opportunities and efficiency benefits which, when passed on to consumers, lead to virtuous cycles of increased demand and renewed potential for scale.

The disappearance of national borders due to the internal market means considerably greater opportunities for Dutch businesses, which have always been very internationally oriented. Dutch firms can benefit from their competitive prices and high productivity ${ }^{25}$. Given the central location of the Netherlands within the EU, a large customer base can be served with goods and services produced in or re-exported from the Netherlands. The Netherlands can act as a "Gateway to Europe" since within a $500 \mathrm{~km}$ radius from Amsterdam, a firm can reach a potential market of 170 million people, almost 50 percent of the entire European population. Due to the developed infrastructure and the ease of trading resulting from the liberalisation-measures, foreign firms can quickly reach this huge market with their products and services. EU integration has therefore resulted in an

\footnotetext{
${ }^{25}$ The deteriorating Dutch economic position in 2001 has resulted in a loss in price competitiveness of Dutch exports due to rapid wage increases (CPB 2001a). Furthermore, labour productivity is declining (DNB 2002). The competitive strength of the Netherlands is therefore declining.
} 
upgrading of the locational advantages of the Netherlands, making it a more attractive location for foreign affiliates.

\subsection{Outward FDI from the Netherlands}

As for most small countries, the effects of EU integration were large in case of the Netherlands. This partly reflects the fact that the relative significance of the national market changes more for countries such as the Netherlands, Belgium, and Sweden than for larger nations such as Germany and the United Kingdom. Relative to the size of the economy, the small countries had outward FDI stocks exceeding 20 percent of GDP in 1990 (Andersson et al. 1996). They are home to successful multinationals with large activities outside their national borders. Table 2.4 gives an indication of the largest MNEs originating in small countries. These firms all belong to the Fortune world top-500 and therefore are among the largest companies in the world. Of the 65 MNEs located in small countries, eight are Dutch (ING group, ABNAmro holding, Ahold, Philips, Aegon, Rabobank, AkzoNobel, and SHV Holdings) and another three have joint Dutch/UK (Shell, Unilever) or joint Dutch/Belgian (Fortis) ownership. Van den Bulcke (1983) has drawn attention to the fact that, in the 1980s, Dutch MNEs were among the world's most internationalised firms. Table 1.3 in Chapter one clearly shows that this trend continues into the 1990s, in terms of employment, sales, and assets abroad (United Nations 1997).

Although it can be argued that large countries offer a better base for the emergence of multinationals, it is clear that the Netherlands has been unusual successful soil for breeding large multinationals. This exceptional Dutch outward FDI position is relatively well documented (see Hoesel and Narula 1999, Nieuwkerk and Sparling 1985, Hogenbirk 1999). There are a number of reasons for the extraordinary position of Dutch multinationals. Industrial innovations in the nineteenth and early twentieth century (in margarine, oil refinery, and lightning) provided the necessary intangible firm-specific assets (a superior technology) needed for firms to invest abroad ${ }^{26}$. Furthermore, large MNEs were stimulated by favourable government policies ${ }^{27}$ and the lack of intellectual property protection up to 1912 (Zanden 1997). It should also be noted that the Netherlands has been well-endowed with both financial and human capital ${ }^{28}$. MNE investments were also facilitated by the knowledge of foreign markets due to intensive trading (particularly with Germany) resulting from a favourable location in Europe, at the North Sea ${ }^{29}$.

\footnotetext{
${ }^{26}$ Zanden (1997) gives a full description of the way the large Dutch multinationals (Unilever, Shell, Philips, Akzo, Hoogovens, and DSM) were established and started their international activities.

${ }^{27}$ Such as plans for industrialisation and the "guided" wage policies (1945-1963).

${ }^{28}$ The high quality human resources resulted from the early investments in the educational system (Zanden 1997).

${ }^{29}$ As early as the seventeenth century, pioneers of the VOC and the Dutch West India Company (WestIndische Compagnie or WIC) created trading settlements in a large number of countries, giving the Dutch extensive knowledge of foreign markets and trading skills.
} 
Table 2.4 Profile of large Fortune 500 MNEs from small industrialised countries (2000)

\begin{tabular}{|c|c|c|c|c|c|c|c|}
\hline Country & $\begin{array}{l}\text { Number } \\
\text { of firms } \\
\text { in list }\end{array}$ & $\begin{array}{l}\text { Number } \\
\text { of } \\
\text { industries }\end{array}$ & $\begin{array}{l}\text { Average } \\
\text { Revenue } \\
\text { (Mill. US\$) }\end{array}$ & $\begin{array}{l}\text { Largest firm of } \\
\text { given nationality } \\
\text { in Fortune list }\end{array}$ & $\begin{array}{l}\text { Revenues } \\
\text { (Mill. US\$) }\end{array}$ & $\begin{array}{l}\text { Fortune } \\
\text { Rank }\end{array}$ & Other firms listed \\
\hline Netherlands & 8 & 6 & 30260 & ING group & 62492.4 & 27 & $\begin{array}{l}\text { ABN Amro Holding, Ahold, Philips, Aegon, Rabobank, } \\
\text { Akzo Nobel, SHV Holdings }\end{array}$ \\
\hline Australia & 7 & 6 & 13668 & AMP & 17760.3 & 252 & $\begin{array}{l}\text { Coles Myer, Broken Hill Proprietary, News Corp. National } \\
\text { Australia Bank, Woolworths, Telstra }\end{array}$ \\
\hline Belgium & 3 & 2 & 11581 & Almanij & 16248.5 & 283 & Delhaize "le Lion", Dexia group \\
\hline $\begin{array}{l}\text { Belgium/ } \\
\text { Netherlands }\end{array}$ & 1 & 1 & 43660 & Fortis & 43660.2 & 55 & \\
\hline $\begin{array}{l}\text { Britain/ } \\
\text { Netherlands }\end{array}$ & 2 & 2 & 74523 & $\begin{array}{l}\text { Royal Dutch } \\
\text { Shell group }\end{array}$ & 105366 & 11 & Unilever \\
\hline Canada & 12 & 8 & 12439 & Nortel Networks & 21287 & 194 & $\begin{array}{l}\text { George Weston, Canadian Imperial Bank of Commerce, } \\
\text { Royal Bank of Canada, Transcanada Pipelines, Seagram, } \\
\text { Bank of Montreal, Bank of Nova Scotia, Sun Life Insuran- } \\
\text { ces, Toronto Dominion Bank, Onex, Power Corp. }\end{array}$ \\
\hline Finland & 2 & 2 & 16218 & Nokia & 21090.4 & 196 & Stora Enso \\
\hline Luxembourg & 1 & 1 & 11363 & Arbed & 11362.7 & 437 & \\
\hline Norway & 2 & 2 & 15538 & Statoil & 17945 & 247 & Norsk Hydro \\
\hline South Korea & 12 & 8 & 20151 & SK & 31997.3 & 105 & $\begin{array}{l}\text { Hyundai, Samsung, Samsung Electronics, Hyundai Motors, } \\
\text { Daewoo, Samsung Life Insurances, LG International, LG } \\
\text { Electronics, Korea Electric Power, Kyobo Life Insurance, } \\
\text { Pohang Iron \& Steel }\end{array}$ \\
\hline Sweden & 4 & 3 & 18844 & L.M. Ericsson & 26052.3 & 140 & Skandia Group, Volvo, Electrolux \\
\hline Switzerland & 11 & 8 & 26593 & Nestlé & 49494.1 & 41 & $\begin{array}{l}\text { Credit Suisse, Zurich Financial Services, UBS, ABB, } \\
\text { Novartis, Swiss Insurance, Roche Group, Swiss Life } \\
\text { Insurance and Pension, Migros, Adecco }\end{array}$ \\
\hline
\end{tabular}

Source: Fortune (2000) 
However, FDI only gained substantial proportions in the twentieth century. Starting from the 1960s onwards, FDI grew rapidly due to improved transportation facilities, communication innovations, and increasing protectionism. The peak of the Dutch presence in the world was recorded in 1980, when 8.1 percent of outward FDI stock originated in the Netherlands, making the country the fourth largest investor in the world. In 1999, Dutch investors still occupy this fourth position, although their share in total stock has declined to 6.4 percent of total due to the emergence of investors from Asia (Japan, Hong Kong, and Singapore) and other European Union countries (United Nations 2000).

The stock of outward FDI from the Netherlands has grown with 173 billion Euro to 252 billion Euro between 1990 and 1999, an average annual growth of 14 percent (see Table 2.5). The EU-member countries received the largest share of total outward investment from the Netherlands, both in industry and services. The largest growth rates, however, occurred in Eastern Europe (particularly in telecommunications in Poland and the Czech Republic, facilitated by the political and economic reforms after the fall of the Berlin Wall in 1989), and South East Asia (particularly in Singapore (oil) and the electronics and metals sectors in South Korea).

Table 2.5 Stock and growth of Dutch FDI abroad, 1999

(Millions EUR, unless otherwise indicated)

\begin{tabular}{|c|c|c|c|c|c|c|c|c|c|c|}
\hline Country/Area & 局 & 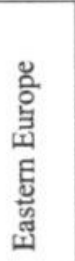 & $\frac{\text { 总 }}{\frac{\mathrm{E}}{5}}$ & 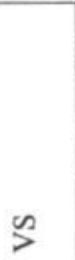 & 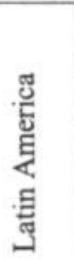 & 茎 & 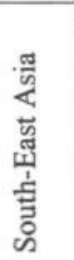 & 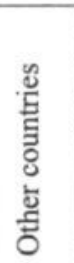 & ख્ & $\frac{\frac{9}{2}}{\frac{1}{2}} \frac{1}{5}$ \\
\hline Mining, oil, and chemicals & 25.9 & 1.9 & 3.0 & 9.7 & 2.9 & 0.3 & 2.8 & 7.0 & 53.4 & 9 \\
\hline Metal \& electronics & 13.8 & 0.5 & 1.2 & 6.2 & 2.5 & 0.4 & 3.6 & 0.9 & 29.0 & 14 \\
\hline Food, drink and tobacco & 4.2 & 1.3 & 3.0 & 6.8 & 1.7 & 0.2 & 1.2 & 1.3 & 19.6 & 15 \\
\hline Other industry & 7.7 & 0.2 & 0.3 & 4.1 & 0.0 & 0.0 & 0.2 & 0.9 & 13.4 & 20 \\
\hline Total industry & 51.5 & 4.0 & 7.4 & 26.7 & 7.1 & 1.0 & 7.7 & 10.1 & 116 & 12 \\
\hline Trade & 15.5 & 0.6 & 1.4 & 1.8 & 2.2 & 0.0 & 1.3 & 0.4 & 23.1 & 14 \\
\hline Transportation and storage & 4.7 & 1.6 & 0.5 & 0.9 & 0.1 & 0.0 & 0.2 & 0.3 & 8.4 & 24 \\
\hline Banking and insurance & 25.5 & 0.9 & 1.4 & 16.6 & 2.7 & 0.3 & 1.0 & 2.8 & 51.1 & 17 \\
\hline Other services & 34.1 & 1.0 & 4.7 & 9.8 & 1.1 & 0.1 & 0.4 & 2.3 & 53.5 & 15 \\
\hline Total services & 79.7 & 4.1 & 8.0 & 29.1 & 6.1 & 0.4 & 2.9 & 5.9 & 136 & 16 \\
\hline Total & 131 & 8.0 & 15.4 & 55.8 & 13.2 & 1.4 & 10.6 & 15.9 & 252 & 14 \\
\hline Growth 1991-1999 & 15 & 108 & 14 & 10 & 10 & 6 & 18 & 13 & 14 & \\
\hline
\end{tabular}

Source: DNB (2001) 
Outside Europe, the US has always been the most important target region. Narula and Hogenbirk (1999) analyse the trends in Dutch investment in the US. They show that at one point in the 1980s, Dutch MNEs accounted for no less than one-quarter of all FDI stock in the US. Since then, this exceptional position has weakened. Although stocks in the US are still over 20 percent of total Dutch investments and the US are by far the largest recipient country (with stocks amounting to EUR 55.8 billion in 1999), average annual growth for 1991-1999 (10 percent) lagged behind overall growth. This slower growth can be attributed to a re-focus of investments towards Europe (due to the process of European unification), but also to problems in the chemical sector and low oil prices. Due to declining profits, reinvested earnings slowed, resulting in fewer additional investments. Sectors in the US that received relatively many new investments include food (partly due to the acquisition of General Nutrition by Numico (see also Table 2.13) and printing and publishing (VNU, Reed Elsevier, and Wolters Kluwer) ${ }^{30}$. Table 2.5 also shows the importance of Dutch financial services in the US. Large acquisitions by ABN AMRO, Aegon, ING group, and Fortis are responsible for this phenomenon (DNB 2001). Investments to Japan slowed, increasing only by six percent annually between 19911999. Dutch investment in Japan is thoroughly analysed by Belderbos (1999). Locational disadvantages and entry barriers kept Dutch and other countries' investments in Japan to a minimum and largely restricted to joint ventures. The share of developing countries in Dutch outward FDI is gradually declining to less then ten percent of total in 1999.

The progressing integration within the European Union has resulted in increased Dutch investments in the region. In 1999, 52 percent of all investments were located in the European Union (46 percent in 1990, and only 30 percent in 1984). As can be seen from Table 2.6, the largest growth rates in Dutch investments occurred in Sweden $(+27$ percent) and Ireland (+38 percent). Growth in Sweden was realised due to the Akzo/Nobel merger (1994), and activities in telecommunications (1999).

Table 2.6 Dutch direct investments in the most important EU countries

(Stocks in billions of Euro, unless otherwise indicated)

\begin{tabular}{|c|c|c|c|}
\hline Country/Area & 1991 & 1999 & $\begin{array}{r}\text { Average annual } \\
\text { growth 1991-1999 }\end{array}$ \\
\hline Belgium and Luxembourg & 8.2 & 33.8 & 17 \\
\hline Germany & 7.5 & 20.9 & 12 \\
\hline France & 6.3 & 15.8 & 11 \\
\hline Ireland & 0.5 & 9.9 & 38 \\
\hline Italy & 1.2 & 4.3 & 15 \\
\hline Spain & 2.6 & 7.4 & 12 \\
\hline United Kingdom & 7.6 & 31.0 & 17 \\
\hline Sweden & 0.2 & 1.9 & 27 \\
\hline Other EU & 2.0 & 6.3 & 14 \\
\hline Total EU & 36.1 & 131.2 & 15 \\
\hline
\end{tabular}

Source: DNB (2001)

${ }^{30}$ See Kranenburg et al. (2001). 
Investments in Ireland occurred due to the favourable location factors, such as cheap and well-educated labour, and favourable fiscal policies. Most Dutch activities in Ireland are subsidiaries of lease firms. The share of Belgium and Luxembourg went up from 7.5 percent in 1974 to 13.4 percent in 1999 , whereas the share of Germany declined from 17.1 percent to 8.3 percent over the same period (Table 2.6). The UK is also an important host for Dutch investment. An important determinant of investment flows between the UK and the Netherlands are the UK-Dutch multinationals such as Shell, Unilever, and Reed-Elsevier. A non-EU target country is Switzerland whose share in total stock amounts to 6.1 percent in 1999 . The Swiss food industry was the largest recipient of FDI flows.

\subsection{Inward FDI in the Netherlands}

In general, much less is known about the inflow of foreign investments in the Netherlands. Although smaller than the FDI outflows, they are still considerable, as can be seen in Figure 2.3 for the period 1968-1999. Until World War II, the Netherlands attracted few foreign investments (Nieuwkerk and Sparling 1985). Important source countries for those early establishments were the US (almost 40 percent of total), the UK, Germany, and Switzerland (Nieuwkerk and Sparling 1985). The investments mostly occurred in the oil and chemical sector, in food, and in metals (Nieuwkerk and Sparling 1985). However, their influence on the Dutch economy was negligible, given their relatively small size.

This situation changed in the 1950 s and 1960 s, largely due to US investments (and the Marshall Plan aid) facilitating the post-war reconstruction of the Netherlands (Loeve 1986). Inflows further accelerated in the 1980 s due to the technological changes and the increasing globalisation of the world economy, amounting to an inward FDI stock of 192 billion Euro by 1999 (see Table 2.7). The Netherlands currently ranks fifth as a recipient of FDI, behind the US (US\$ 1087 billion), the UK (US\$ 394 billion), China (US\$ 306 billion), and Germany (US\$225 billion) (United Nations 2000).

In 1999, FDI inflow is dominated by foreign investments from the US (47.9 million Euro) and the EU (103 million Euro) as can be seen in Tables 2.7 and 2.8. European investments did grow by 18 percent annually between 1991-1999, a slightly larger increase than for overall investments. With the exception of mining, oil, and chemicals, all sectors shared in this growth. As a result, the share of EU investments in total inward FDI in the Netherlands increased from 46 percent in 1991 to 54 percent in 1999. Within Europe, the most important investors in the Netherlands are its neighbours Germany $(+19$ percent annually) and Belgium $(+19$ percent annually) and also the UK $(+15$ percent annually). The extraordinary growth of Irish investments in the Netherlands must be attributed to the acquisition of Van Nelle by Imperial Tobacco in 1998. Non-EU European investments are mostly made up by Swiss investments in the food sector. The 
strong growth in the category "other countries" (Table 2.6) can be explained by the takeover of Polygram by Seagram (Canada).

Figure 2.3

Dutch FDI Flows, 1968-1998

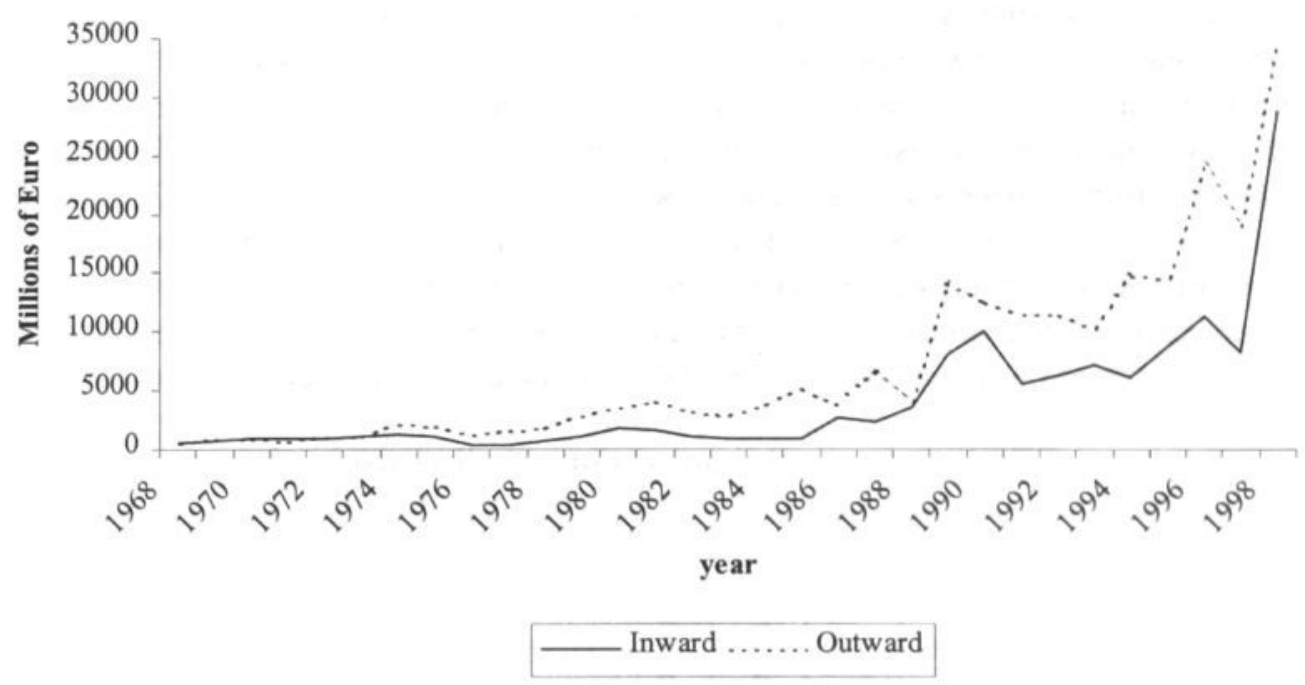

Source: DNB Annual reports, several issues

The US investments mostly take place in the mining, oil, and chemical sector. Many US firms have chosen the Botlek and Maasvlakte areas for new establishments targeting the EU market. One example is Lyondell Chemical that announced the signing of a contract for the engineering, procurement, and construction of its world-scale propylene oxide (PO) plant in Rotterdam in May 2000. Lyondell already has an existing PO plant near Rotterdam and is building a new butanediol (BDO) plant, scheduled for start-up in 2002. The new PO plant is expected to be a joint undertaking with the German firm Bayer and will begin operating in 2003.

Several factors make the Netherlands an interesting location for foreign investors and account for the extraordinary inflow of FDI. Among those are the virtual absence of exchange controls ${ }^{31}$, the availability of capital on the domestic capital markets, the stable economic and political climate, and the absence of restrictions on the repatriation of

\footnotetext{
${ }^{31}$ Exchange controls consist of government laws, degrees or regulations that restrict the export or import of capital by non-residents. Exchange controls restrict the ability to acquire foreign currency. Governments use exchange controls to protect the exchange rate, to ration imports (to protect local producers), and to isolate the economy from (undesirable) external market factors.
} 
earnings, profits, capital, royalties or loan interest (Hogenbirk 1999). Furthermore, a wide array of investment incentives such as grants are offered to all investors, including foreign. The unique location on the European Continent ${ }^{32}$ makes the Netherlands a perfect gateway for doing business in the European Union, facilitated by a welldeveloped transportation infrastructure (Minne 1997). The education level is high and the workforce is generally bi-lingual (NFIA 1997a, 1997b). Skilled foreign managers and specialised staff may normally be employed (Ernst and Young 1996). The exceptions in the tax system offer an additional attraction (Boeckhout et al. 1987). The deciding determinants differ by type of foreign activity conducted by the investor ${ }^{33}$.

Table 2.7 indicates that the largest growth of new foreign investments occurred in the metal and electronics industry and in transportation and storage. Minne (1997) shows that many electronics firms - such as Canon, Digital, Apple, Texas Instruments, Compaq, Sun Microsystems, Toshiba, Sony, IBM - have a European distribution centre in the Netherlands. He therefore emphasises the importance of logistics. The standardised components in this industry can be transported easily at low costs. Firms can therefore position parts of the value-added chain wherever in the world production costs are lowest.

Table 2.7 Stock and growth of FDI in the Netherlands, 1999

(Millions of Euro, unless otherwise indicated)

\begin{tabular}{|c|c|c|c|c|c|c|c|c|c|c|}
\hline Country/Area & 로 & 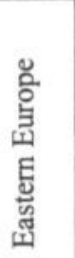 & $\frac{\text { 恖 }}{\text { 岁 }}$ & $\stackrel{\infty}{>}$ & 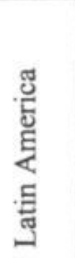 & 茎 & 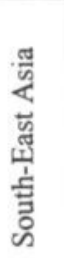 & 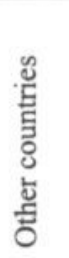 & 푱 & $\frac{\frac{2}{2}}{\frac{2}{2}}$ \\
\hline Mining, oil, and chemicals & 11.7 & 0.0 & 1.5 & 17.1 & 2.8 & 0.1 & 0.0 & 1.3 & 34.4 & 9 \\
\hline Metal \& electronics & 10.1 & 0.0 & 0.3 & 2.6 & -0.1 & 0.4 & -0.1 & 9.2 & 22.5 & 24 \\
\hline Food, drink and tobacco & 3.8 & 0.0 & 3.0 & 3.1 & 1.0 & 0.0 & 0.0 & 0.4 & 11.2 & 16 \\
\hline Other industry & 8.2 & 0.0 & 0.3 & 1.7 & 0.4 & 0.0 & 0.0 & 0.1 & 10.7 & 14 \\
\hline Total industry & 33.8 & 0.0 & 5.0 & 24.4 & 4.2 & 0.5 & 0.0 & 10.9 & 78.8 & 14 \\
\hline Trade & 17.5 & 0.0 & 2.0 & 6.9 & 3.8 & 1.6 & 0.6 & 0.3 & 32.8 & 16 \\
\hline Transportation and storage & 6.5 & 0.0 & 0.6 & 1.4 & 0.2 & 0.0 & 0.0 & 0.1 & 9.0 & 35 \\
\hline Banking and insurance & 10.6 & 0.0 & 0.6 & 2.7 & 0.1 & 0.4 & 0.2 & 0.1 & 14.8 & 14 \\
\hline Other services & 34.8 & 0.0 & 2.3 & 12.5 & 4.0 & 0.4 & 0.2 & 2.1 & 56.4 & 18 \\
\hline Total services & 69.5 & 0.1 & 5.5 & 23.5 & 8.2 & 2.5 & 1.1 & 2.6 & 113 & 17 \\
\hline Total & 103 & 0.1 & 10.5 & 47.9 & 12.3 & 3.0 & 1.0 & 13.6 & 192 & 16 \\
\hline Growth 1991-1999 & 18 & 33 & 9 & 16 & 7 & 4 & 14 & 34 & 16 & \\
\hline
\end{tabular}

Source: DNB (2001)

\footnotetext{
${ }^{32}$ The Netherlands is within easy reach of 300 million people in the European market.

${ }^{33}$ The emphasis in this section is on the factors that make the Netherlands an attractive location for foreign investors. However, it is impossible to ignore the negative influences. The most important deterrents to foreign investors include the tight labour market, high labour costs, and congestion (Beers et al. 1999).
} 
When assembling all components, the ease of transportation of the final products to the customer becomes important. Europe is an important market of computers and electronic systems. Within Europe, the Netherlands can be such a central distribution knot. High quality logistic services make the Netherlands attractive for activities in this industry.

Other firms try to exploit the Dutch specific natural endowment of its location at the sea and river deltas. This is particularly true for chemical firms such as Du Pont, Hoechst, Dow Chemical, ICI, Exxon, Texaco/BP, and Kuwait Petroleum. They transport the oil to the Netherlands, adapt the product, and then distribute it to Northern-European countries. These firms benefit from agglomerated know how on logistics, international marketing, and finance and the mastering of foreign languages (Minne 1997). Foreign food processing firms try to benefit from the agglomerated know how in the field of agricultural industry. Companies like Philip Morris, Nestlé and Henkel therefore have establishments in the Dutch market.

It is remarkable to note that although Dutch inward FDI stock in industry is considerable, almost 59 percent of FDI concerns investments made in the services sector (see Table 2.7). A major distinction between services and primary and secondary goods is that the latter can in principle always be sold through exports. In case of tertiary activities, there is no such choice. Their output has to be sold through a physical presence in the local market (Stibora and Vaal 1999). We therefore see Dutch sales and service establishments for many foreign pharmaceutical companies and automobile producers (Minne 1997). The increasing importance of services FDI matches the increasing importance of the tertiary sector in general, and in the Netherlands in particular (as could be seen in Table 2.2).

Table 2.8 Inward FDI in the Netherlands by the most important EU countries (Stocks in billion EUR, unless otherwise indicated)

\begin{tabular}{|l|r|r|r|}
\hline Country/Area & 1991 & 1999 & $\begin{array}{r}\text { Average annual } \\
\text { growth 1991-1999 }\end{array}$ \\
\hline Belgium and Luxembourg & 4.9 & 24.1 & 19 \\
Germany & 4.4 & 21.5 & 19 \\
France & 2.5 & 8.9 & 15 \\
Ireland & 0.3 & 8.5 & 44 \\
Italy & 0.1 & 0.6 & 25 \\
Spain & 0.1 & 0.5 & 22 \\
United Kingdom & 7.9 & 27.2 & 15 \\
Sweden & 2.4 & 8.7 & 16 \\
Other EU & 0.8 & 3.3 & 17 \\
Total EU & $\mathbf{2 3 . 4}$ & $\mathbf{1 0 3 . 3}$ & $\mathbf{1 8}$ \\
\hline
\end{tabular}

Source: DNB (2001)

Table 2.9 shows the largest foreign investors in the Netherlands. We have included only those firms that had at least 500 million Euro sales in the Netherlands in 1997. We can see that firms from most large industrialised countries have establishments in the Netherlands. Some of the largest investors (particularly those in traditional industries such as oil and food-processing) came as early as the beginning of the $20^{\text {th }}$ century. The 
activities of the foreign investors are diverse and range from pharmaceuticals to cars. The list also includes three foreign establishments active in electronics - IBM Nederland, Siemens, and Sony Benelux. Part of this study (Chapters five and six) will analyse affiliates in the electronics sector in more detail by means of a questionnaire survey.

Foreign investments can take many ownership forms, such as greenfield establishments, joint ventures, and acquisitions. Although historically greenfield investments were the most common way of FDI, increasingly international business activities involve joint ventures (Bell 1996, Kemp 1999) or mergers and acquisitions (M\&A). This is also true in case of Dutch firms. Table 2.10 gives an overview of cross-border M\&A deals with values of over US\$ 2 billion that were completed in 1999 and involved Dutch firms. The table shows that for both inward and outward Dutch FDI acquisitions have become an important mode. The largest acquisition was made by insurance company Aegon who bought the US firm TransAmerican for US\$ 10.8 billion. The merger of British Steel and Hoogovens resulted in the "Corus group".

\subsection{Foreign establishments in the Netherlands}

Behind the large Dutch inward investment stocks are over 7,000 individual firms employing more than 350,000 people. The DutchInvest database created for this study (see Appendix A) allows us to analyse the characteristics of those firms. Table 2.11 gives an overview of the home country distribution of these affiliates in the Netherlands.

Seventy-one countries had establishments in the Netherlands in 1999. However, the importance of countries differs significantly. Some countries, like Zambia and Ivory Coast have only one establishment, while the largest investor in terms of establishments, the United Kingdom, has as many as 1,386 . We see that this pattern matches the investment stocks and flows analysed in Section 2.7.

In 1999, firms from the United Kingdom, Germany, and the United States all had more than 1,300 Dutch establishments. Establishments by firms from Belgium, France, and Japan follow, making up 8.6, 6.3 and 5.6 percent of all establishments, respectively. Sixty-five percent of all currently present establishments resulted from intra-European investment flows. Furthermore, the importance of Japanese investments, in particular in the early 1990s, is quite considerable. Although their contribution to total FDI stock is still limited to 0.5 percent of all inward FDI stock (DNB 2000b), the number of establishments is relatively large.

The data gathered in the DutchInvest database also allow an industry analysis of the business activities of the foreign affiliates in the Netherlands. Appendix A at the end of this book gives a detailed overview of all establishments ordered by SICcode1987. To be able to compare these data with statistics from the Dutch Central Bureau of Statistics (CBS), we present a shorter table in this section, ordered by SBI-'93, the standard classification used in the Netherlands. We consider only those establishments present in the Netherlands on January $1^{\text {st }}, 1997$. 
Table 2.9 Examples of large foreign investors in the Netherlands, ordered by 1997 sales volume

\begin{tabular}{|c|c|c|c|c|c|}
\hline Firm & Sector & $\begin{array}{l}\text { Employment } \\
\text { in NL (1997) }\end{array}$ & $\begin{array}{c}\text { Sales in NL } 1997 \\
\text { (Mill. EUR) }^{*}\end{array}$ & $\begin{array}{c}\text { Year of establish- } \\
\text { ment in NL }\end{array}$ & Parent country \\
\hline Exxon Nederland & Chemicals & 1505 & 4481 & 1965 & United States \\
\hline Otra & Electro-technical equipment & 5756 & 1810 & 1909* & France \\
\hline Fina Nederland & Oil & 4637 & 1338 & 1927 & Belgium \\
\hline Merck Sharp \& Dohme (MSD) & Pharmaceuticals & 1038 & 1214 & 1954 & United States \\
\hline IBM Nederland & Electronics & 3985 & 1125 & 1940 & United States \\
\hline Siemens groep & Electronics & 2768 & 1075 & 1879 & Germany \\
\hline Kuwait Petroleum (Nederland) & Oil & 540 & 967 & 1926 & Kuwait \\
\hline McCain Europa BV & Food processing & 4874 & 934 & 1972 & Canada \\
\hline Du Pont de Nemours (Nederland) & Chemicals & 2225 & 885 & 1959 & United States \\
\hline Daimler-Benz Holding Nederland & Cars & 607 & 785 & 1986 & Germany \\
\hline BASF Nederland & Chemicals & 1059 & 756 & 1947 & Germany \\
\hline Ericsson Nederland & Telecommunications & 2247 & 666 & 1973 & Sweden \\
\hline Nestlé Nederland & Food processing & 1518 & 651 & 1912 & Switzerland \\
\hline Fuji Photo Film BV & Photo-chemicals & 1367 & 613 & 1982 & Japan \\
\hline Ford Nederland & Cars & 100 & 600 & 1929 & United States \\
\hline Mars & Food-processing & 1161 & 562 & 1961 & United States \\
\hline Sony Benelux & Electronics & 670 & 562 & 1924 & Japan \\
\hline Solvay Nederland & Chemicals & 2373 & 507 & 1930 & Belgium \\
\hline
\end{tabular}

Source: Financieele dagblad, omzetcijfers 1997; Reach database.

* Part of Otra's shares were owned by Sonepar S.A. (France) since 1982. A full take-over occurred in 1999.

"As of January $1^{\text {st }}, 2002$, the official Dutch currency is the Euro (1 Euro = f 2.20371). 
Table 2.10 Cross-border M\&A deals with values of over US\$ 2 billion, completed in 1999

\begin{tabular}{|c|c|c|c|c|c|c|}
\hline Name of acquiring company & Country & Industry & Name of acquired company & Country & Industry & Value $^{1}$ \\
\hline Aegon NV & NL & Insurance & TransAmerica Corp & US & Insurance & 10.8 \\
\hline Japan Tobacco Inc & Japan & Tobacco products & RJ Reynolds International & NL & Tobacco products & 7.8 \\
\hline New Holland & NL & Machinery & Case corp. & US & Machinery & 6.2 \\
\hline British Steel PLC & UK & $\begin{array}{l}\text { Metal and Metal } \\
\text { products }\end{array}$ & Koninklijke Hoogovens NV & NL & $\begin{array}{l}\text { Metal and metal } \\
\text { products }\end{array}$ & 3.2 \\
\hline Reckitt \& Colman PLC & UK & Pharmaceuticals & Benckiser NV & NL & $\begin{array}{l}\text { Soaps, cosmetics } \\
\text { and personal-care } \\
\text { products }\end{array}$ & 3.1 \\
\hline Pinault-Printemps Redoute & France & Retail-trade & Gucci Group NV & NL & $\begin{array}{l}\text { Leather and Leather } \\
\text { products }\end{array}$ & 2.9 \\
\hline Verenigd Bezit VNU & NL & $\begin{array}{l}\text { Printing, } \\
\text { publishing and } \\
\text { allied services }\end{array}$ & Nielsen Media Research Inc. & US & Business Services & 2.8 \\
\hline Koninklijke Numico NV & NL & $\begin{array}{l}\text { Food and Kindred } \\
\text { products }\end{array}$ & General Nutrition Companies & US & $\begin{array}{l}\text { Retail trade, food } \\
\text { stores }\end{array}$ & 2.5 \\
\hline ING Group NV & NL & Insurance & BHF Bank & Germany & Commercial banks & 2.3 \\
\hline Buhrmann NV & NL & $\begin{array}{l}\text { Paper and Allied } \\
\text { products }\end{array}$ & Corporate Express Inc & US & $\begin{array}{l}\text { Miscellaneous } \\
\text { Retail Trade }\end{array}$ & 2.3 \\
\hline
\end{tabular}

Source: United Nations (2000)

${ }^{1}$ Value represents the price paid by the buying firm for the stake in the acquired firm, measured in USS 
Table 2.11 Home countries of foreign establishments in the Netherlands (1999)

\begin{tabular}{|c|c|c|c|}
\hline Home country/Region & Number & Share in total & Total Employment in the NL \\
\hline Austria & 48 & 0.6 & 1331 \\
\hline Belgium & 643 & 8.6 & 17741 \\
\hline Denmark & 135 & 1.8 & 13517 \\
\hline Fed. Republic of Germany & 1368 & 18.3 & 58990 \\
\hline Finland & 65 & 0.9 & 4240 \\
\hline France & 471 & 6.3 & 23098 \\
\hline Greece & 3 & 0.0 & 40 \\
\hline Ireland & 83 & 1.1 & 3121 \\
\hline Italy & 216 & 2.9 & 3678 \\
\hline Luxembourg & 105 & 1.4 & 3898 \\
\hline Portugal & 9 & 0.1 & 37 \\
\hline Spain & 52 & 0.7 & 410 \\
\hline Sweden & 248 & 3.3 & 16483 \\
\hline United Kingdom & 1386 & 18.5 & 61443 \\
\hline EU(14) & 4832 & 64.6 & 208027 \\
\hline Switzerland & 414 & 5.5 & 22409 \\
\hline Canada & 82 & 1.1 & 6461 \\
\hline United States & 1350 & 18.0 & 105584 \\
\hline Japan & 417 & 5.6 & 21272 \\
\hline Remaining Countries & 389 & 5.2 & 8675 \\
\hline Total & 7484 & 100.0 & 372428 \\
\hline
\end{tabular}

Source: DutchInvest Database (1999)

We can see from Table 2.12 that on January $1^{\text {st }} 1997$, foreign establishments (7416) account for 1.2 percent of all establishments (641705) in the Netherlands. On average, foreign establishments are larger than Dutch firms. Over 90 percent of all Dutch establishments employ up to nine people. However, only 53 percent of all foreign establishments are that small. Just one percent of all Dutch establishments is large (employing over 100 people) compared to almost 9 percent of foreign firms ${ }^{34}$. This can easily be explained by the fact that foreign establishments capitalise on e.g. parent technology, an established brand name, experience, or skills. It may therefore be easier to survive and grow than for Dutch firms that also include many new, risky start-ups that generally exit the market quite quickly again.

\footnotetext{
${ }^{34}$ Diederen (2000) indicates that 25 percent of all large Dutch firms in his sample have a foreign parent, mostly in the US.
} 
Table 2.12 illustrates that investments of foreign firms are particularly important in a number of sectors. First of all, in mining 20 percent of all Dutch establishments have a foreign parent. However, one has to take into consideration that this also includes all oil companies that own gas stations in the Netherlands. Furthermore, 19 percent of all financial institutions (including holdings) are foreign. This considerable share could be explained by a particularly favorable tax system (Boeckhout et al. 1987, DNB 2000a). Though financial institutions make up only two percent of all Dutch establishments, their share in foreign investments is close to 30 percent. Looking more specifically at the foreign investments only, we see that most investments are made in repair and trade (37 percent of total). Financial institutions follow, with 29 percent of total establishments still in business in 1997. One out of eight establishments is a manufacturing firm and one in ten is in rental and business services.

Table 2.12 Companies in the Netherlands, 1/1/1997, grouped by activity

\begin{tabular}{|c|c|c|c|c|c|c|}
\hline Group & $\begin{array}{l}\text { Industry (based on the SBI-'93 } \\
\text { classification) }\end{array}$ & $\begin{array}{c}\text { Totaal } \\
\text { (T) }\end{array}$ & $\begin{array}{l}\text { Share } \\
(\mathrm{Tx} / \mathrm{T})\end{array}$ & $\begin{array}{l}\text { Foreign } \\
\text { (F) }\end{array}$ & $\begin{array}{l}\text { Share } \\
(\mathrm{F} / \mathrm{T})\end{array}$ & $\begin{array}{l}\text { Share } \\
(\mathrm{Fx} / \mathrm{F})\end{array}$ \\
\hline $\mathrm{A}$ & Agriculture, Hunting and Forestry & 107375 & 16.7 & 16 & 0.0 & 0.2 \\
\hline B & Fishing & 760 & 0.1 & 1 & 0.1 & 0.0 \\
\hline $\mathrm{C}$ & Mining & 210 & 0.0 & 41 & 19.5 & 0.6 \\
\hline D & Manufacturing & 45065 & 7.0 & 942 & 2.1 & 12.7 \\
\hline E & Utilities & 190 & 0.0 & 4 & 2.1 & 0.1 \\
\hline F & Construction & 50650 & 7.9 & 99 & 0.2 & 1.3 \\
\hline G & Repair and Trade & 161940 & 25.2 & 2753 & 1.7 & 37.1 \\
\hline $\mathrm{H}$ & Hotels, Restaurants, Bars & 38135 & 5.9 & 29 & 0.1 & 0.4 \\
\hline I & $\begin{array}{l}\text { Transportation, Communication and } \\
\text { Storage }\end{array}$ & 24565 & 3.8 & 399 & 1.6 & 5.4 \\
\hline $\mathbf{J}$ & Financial Institutions (incl. holdings) & 11485 & 1.8 & 2143 & 18.7 & 28.9 \\
\hline $\mathrm{K}$ & Rental and Business Services & 103350 & 16.1 & 698 & 0.7 & 9.4 \\
\hline L & Public Administration & 1280 & 0.2 & 0 & 0.0 & 0.0 \\
\hline M & Educational Services & 16595 & 2.6 & 11 & 0.1 & 0.1 \\
\hline $\mathrm{N}$ & Health Services & 41875 & 6.5 & 6 & 0.0 & 0.1 \\
\hline \multirow[t]{2}{*}{$\mathrm{O}$} & Culture, Recreation, and Other Services & 38230 & 6.0 & 274 & 0.7 & 3.7 \\
\hline & Total & 641705 & & 7416 & 1.2 & \\
\hline \multirow[t]{3}{*}{ Size } & $(582735=90.8 \%)$ & 582735 & 90.8 & 3969 & 53.5 & \\
\hline & Medium $(10-99) \quad(52560=8.2 \%)$ & 52560 & 8.2 & 2085 & 28.1 & \\
\hline & Large $(>100) \quad(6410=1.0 \%)$ & 6410 & 1.0 & 647 & $8.7^{1}$ & \\
\hline
\end{tabular}

Source: CBS (1997) Bedrijven in Nederland, $1997+$ Dutchlnvest Database 1999

'Numbers do not add up to 100 because for 715 foreign firms (9.6 percent of total) employment figures are not available 


\subsection{Types of foreign investments}

There are many different kinds of activities that firms undertake in foreign markets and firms are therefore attracted to a particular foreign market for different reasons. The most commonly used classification distinguishes resource-seekers, market seekers, efficiency seekers, and strategic asset or capability seekers ${ }^{35}$. This section discusses the potentially attractive factors that could make the Netherlands an interesting location for all these types of multinationals.

Resource seekers are firms that invest abroad to acquire resources at a lower cost than can be obtained in the home market or to gain privileged access to resources vis-à-vis competitors. These resources can be physical, such as minerals, raw materials, and agricultural products but also production factors such as unskilled labour or technological expertise, and management, marketing, and organisational skills. For the Netherlands we see that fertile soil has favoured an extensive agricultural sector and investments in foodprocessing industries. Natural resources are limited, mostly consisting of petroleum and gas that is exploited by Dutch firms. Created assets are potentially more attractive for foreign investors. The Dutch labour force is highly skilled ${ }^{36}$ and linguistically proficient and overall labour productivity is high. The Dutch labour force therefore consists of employees that are attractive for foreign firms.

Market seekers are firms that invest in a country or region to supply goods and services to that country's markets. These firms may invest to sustain or protect existing markets (usually previously supplied through exports), or to exploit or promote new markets. In some cases the firms follow existing clients, customers, or competitors that have started operations abroad. In other cases they feel the need to adapt their products to local taste and needs and prefer to make those adaptations in the host market. Furthermore, the costs of supplying a foreign market with locally produced goods may be smaller than when exporting from a distant location. Undoubtedly the most important reason remains the actions of host governments using investment incentives or trade restrictions. In case of the Netherlands, we see that although the local market size is relatively small (with only 15.7 million, relatively high income, inhabitants), the de facto market size is huge resulting from a favourable location within the European Union and good infrastructural provisions. Non-discriminatory government policies have made foreign establishments

\footnotetext{
${ }^{35}$ Dunning (1993) introduced this classification, borrowing from and extending on Behrmann (1972).

${ }^{36}$ The OECD (2001) has signalled that educational spending in the Netherlands is relatively low (4.6 percent of GDP) and is not keeping up with overall economic growth. Furthermore, 65 percent of total population manage to get a high school diploma. Although slightly above the OECD average (64 percent) this is considerably lower than in the United Kingdom, Denmark, or Germany ( $>80$ percent). Only 0.6 percent of tertiary schooling graduates chose for technical training. Dutch teachers spend a lot of hours teaching relatively big classes, for relatively little pay. Furthermore, the teaching population in the Netherlands is ageing more rapidly than in the neighbouring countries. Replacement is lacking, endangering the continuation of the educational system. If this situation does not change, the Netherlands might loose the competitive strength of highly skilled labour in the near future.
} 
relatively easy. Furthermore, the Dutch economy has made a remarkable recovery after the two oil crises in the 1970s. The renowned "Polder"-model has resulted in economic growth rates that were larger than in most European countries ${ }^{37}$. In addition, the Netherlands is characterised by a stable political environment. It is therefore an attractive location for market-seeking foreign investments.

Efficiency seekers are firms that rationalise their activities in such a way that they gain from the common governance of geographically dispersed activities. The benefits usually exist of economies of scale and scope and of risk diversification. These firms locate their activities in a limited number of countries and supply multiple markets from there. They take advantage of different factor endowments, cultures, institutional arrangements, and market systems. Open and well-developed cross-border markets (such as those in regionally integrated markets) facilitate efficiency-seeking investments. The economic integration in Europe allows these efficiency-seeking firms to restructure their European activities in one location and exploit economies of scale and scope. In case of the Netherlands we see that good transportation facilities such as Schiphol Airport, the Rotterdam harbours, and the direct waterway-connection to Germany allow efficiencyseeking investments within the Dutch borders.

These first three types of investments are usually grouped as "asset-exploiting", signalling that they try to take advantage of locally existing resources and capabilities. The fourth type of investments is "asset-augmenting". The interplay between local and foreign resources results in a potentially mutually beneficial upgrading of competitiveness. These strategic asset-seeking investments are conducted by firms that engage in FDI mainly to acquire assets that will strengthen their long-term global innovatory or production competitiveness. This happens for example in case the acquisition opens up new markets, creates R\&D synergies, production economies, or results in increasing market power, lowers transaction costs, or enables risk spreading. In case of the Netherlands, this could mean locating near or cooperating with large Dutch MNEs hoping for technological spillovers.

\subsection{Conclusion}

Although small in size, in terms of population and geographic area, the Netherlands has been a very attractive location for foreign establishments of many kinds and many countries. Particularly firms from the US (such as Exxon, Merck Sharpe \& Dohme, and Du Pont de Nemours) and those from European, frequently neighbouring, countries (such as Siemens and BASF Chemicals from Germany and Solvay from Belgium) have opened affiliates within the Dutch borders. In total, over 7000 foreign firms have chosen the Netherlands as a location. The share of services in total foreign investment has increased to almost 59 percent.

${ }^{37}$ See also footnotes 6,7 , and 25 . 
Foreign firms located in the Netherlands can take advantage of the favourable economic climate that has characterised the Dutch economy during the last decade. The economic growth in the Netherlands has outpaced that of the average European country for several years. The joint efforts of employers, trade unions, and successive governments (known as the "Polder"-model) have led to economic stability and prosperity.

Foreign firms can also benefit from the unique geographical location of the Netherlands in Europe. Ever since the Golden Age, the Dutch have capitalised on their strategic location at the North Sea at the estuaries of two large rivers, Rhine and Meuse. This position offers unique possibilities for (transit) trade to many European locations. Given the small size of the local economy, the Netherlands is largely dependent on trade for economic prosperity and has therefore created and facilitated an open economy. Considerable infrastructural investments are made to enhance the trade relations. Important provisions include Schiphol airport and the Rotterdam harbours and the Betuwe-lijn. They serve the distributional aims of both home-based (Philips, Shell, DSM, Unilever, Ahold) and foreign MNEs. They are constantly modernised and expanded to preserve the Dutch gateway to Europe.

The Netherlands' strategic location within Europe is further enhanced by the process of European integration in which the Netherlands was an initiating and driving force. The European unification has resulted in the removal of barriers to trade and an enhancement of capital and labour movements, resulting in an enlarged permeability of national borders. The relative ease with which foreign firms can now reach many customers from a single European location has enlarged the de facto Dutch market size from 16 million to almost 300 million people. The Netherlands therefore offers an excellent entrance to Europe for market- and efficiency-seeking investors.

Many foreign establishments choose a location within the Randstad, a conurbation broadly covering the area in the circle Amsterdam, the Hague, Rotterdam, and Utrecht. Although densely-populated (resulting in for example traffic jams and high living expenses) it is an attractive location for many foreign firms. They can benefit from the experience of their predecessors and hope for (technological) spillovers and agglomeration economies. The presence and behaviour of large, internationally oriented Dutch MNEs offers an additional attraction. Resource-seeking investors can benefit from the presence of the skilled, multi-lingual Dutch population.

Despite the, for a small economy, extraordinary inward investment position and the many locational attractions the Netherlands has to offer for foreign firms, up till now relatively little academic research has analysed the actual determinants of inward foreign direct investment in the Netherlands. We bridge this gap in this thesis by analysing Dutch inward FDI from several angles. We start our analyses with a macro-economic study of the determinants of FDI inflows in the Netherlands in Chapter three. 


\section{Chapter three}

\section{THE Determinants OF FDI in THE NeTHERLANDS: A MaCro ANALYSIS}

\subsection{Introduction}

One of the most distinctive features of the post-war era has been the increasing significance of multinational firms in the world economy (Billington 1999, Narula and Wakelin 2001). Chapter one has shown that, in general, the inflow of FDI can have considerable positive consequences for the allocation on capital and labour markets in a host economy. Furthermore, FDI inflows may result in building and upgrading of the local innovative capabilities and competitiveness. In addition, increasing trade flows resulting from FDI may capture new markets and MNE-activity may improve the efficiency of the production system and the existing assets. Given these positive influences, many governments nowadays take a much more welcoming stance towards inbound FDI than in the $1960 \mathrm{~s}$ and 1970 s, when most host governments feared that the monopoly power of multinationals would enable them to extract unacceptably large shares of the value added of the affiliates (Dunning 1994). Host governments are now concerned that without inward investment, they may be deprived of the advantages of being part of an integrated international production and marketing system and therefore sometimes even compete for new establishments with other (neighbouring) countries (Dunning 1994). It is therefore of considerable importance for host country governments to understand the favourable influences on the decision of MNEs to start activities in a particular location. If they know the factors that determine the actual location choice, host governments may be able to manipulate and upgrade these factors so as to attract extra FDI to their own country (Billington 1999).

Several empirical studies have attempted to explain inward FDI from a macro-economic perspective, considering economic, political, cultural, technological, and geographic variables that have influenced the flow of capital between home and host countries. Important examples include Grosse and Trevino (1996) for the US, Yang et al. (2000) for Australia, Zhao and Zhu (2000) for China, Bajo-Rubio and Sosvilla-Rivero (1994) for Spain, Love and Lage-Hildalgo (2000) for Mexico, and Narula and Wakelin (2001) for France, Germany, Italy, the Netherlands, Sweden, the UK, and Japan. This present study is motivated by the absence of a comparable systematic and in-depth empirical study on the macro-economic determinants of foreign direct investment inflows in the Netherlands. To bridge this gap, our objective in this study is to test for the significance of various theoretical factors that might explain the Dutch inward FDI flows. We want to determine the influence of important locational variables such as existing trade relations 
(given the favourable location of the Netherlands in Europe), political and economic stability, and price variables such as wage levels.

An important feature of this study is that multinational activity is taken to be a function of both the characteristics of the host and the home country. Theory suggests that when foreign investment is undertaken, firms engage in the selection of a location based on the advantages of that location relative to those in the home country (Lall 1980). Comparative advantages therefore clearly matter in the MNE's selection of foreign production or sales locations. In this present study, particular attention is therefore paid to the differentials in cost factors between the home country and the Netherlands. The analysis of FDI in a single country (the Netherlands) controls for host country effects that could obscure the home country factors of interest to this study. This study covers the period 1987-1999. We analyse FDI flows to the Netherlands from $28^{1}$ home countries. Depending on the year analysed, these countries' investments make up 80 to 99 percent of total inward FDI flow in that particular year.

This chapter is structured as follows. A brief overview of the inward FDI position of the Netherlands is given in Section two. In Section three, the theoretical and empirical studies on the macro-determinants of inward FDI are discussed, followed by hypotheses about the contribution of different variables in Section four. Section five gives a description of the model used to test these hypotheses. Section six gives an overview of the data used for this study. Section seven shows the results of the model estimations that are discussed in further detail in Section eight. Conclusions are given in Section nine.

\subsection{Inward FDI in the Netherlands}

The Netherlands, though only a small industrialised country, is a large recipient of FDI flows by world standards. Chapter two provided a thorough introduction to the Dutch inward investment position. Traditionally the US, the UK, Germany, Switzerland, and Belgium have been the largest investors in the Netherlands (Nieuwkerk and Sparling 1985). With the progressing integration of the European Union, other EU-members such as France, Ireland, and Sweden have become more important inward investors as well (DNB 2000b). Table 3.1 gives on overview of the geographical distribution of inward FDI stocks in the Netherlands between 1987-1999. From this table it is clear that the major industrialised countries have been the source of most FDI inflow in the Netherlands during the last decade. In fact, the 10 industrialised countries listed in Table 3.1 accounted for 84-89 percent of the value of FDINL for the period under study.

The relative importance of home countries has shifted. Investments by firms that have a home in the United States dominated all investments in 1987, making up 31 percent of total investment stock. By 1999, this share had declined to only 25 percent. During this same period, the European Union members have increased their importance in total

\footnotetext{
'DNB (the Dutch Central Bank) reports annual FDI inflows from 29 countries to the Netherlands but Luxembourg is excluded from the analyses due to missing data.
} 
Dutch FDI inflows considerably, from 38 percent to almost 54 percent in total. Investments from Germany and Belgium now each make up 11 percent of total investments, coming from nine percent and five percent respectively in 1987. This development signals a restructuring of overall investments within the European Union (EU) following the successive stages of increasing regional integration ${ }^{2}$, as discussed in Chapter two.

Table 3.1 Stock of Inward FDI in the Netherlands, several years

(Million EUR)

\begin{tabular}{|l|r|r|r|r|r|r|r|}
\hline Top-10 countries 1999 & 1987 & 1989 & 1991 & 1993 & 1995 & 1997 & 1999 \\
\hline All & $\mathbf{3 4 0 7 1}$ & $\mathbf{4 4 0 0 6}$ & $\mathbf{5 4 4 8 3}$ & $\mathbf{6 3 5 7 0}$ & $\mathbf{8 1 8 5 6}$ & $\mathbf{1 0 8 9 5 0}$ & $\mathbf{1 9 1 6 9 6}$ \\
All EU & $\mathbf{1 2 9 3 6}$ & $\mathbf{1 9 2 1 8}$ & $\mathbf{2 4 7 5 6}$ & $\mathbf{3 1 0 3 9}$ & $\mathbf{4 2 6 6 3}$ & $\mathbf{5 7 2 7 6}$ & $\mathbf{1 0 3 2 7 2}$ \\
USA & 10598 & 11888 & 13731 & 14294 & 17971 & 28169 & $\mathbf{4 7 9 1 1}$ \\
United Kingdom & 5059 & 6971 & 7692 & 8612 & 12144 & 18038 & 27242 \\
Germany & 3116 & 3829 & 4860 & 5831 & 8496 & 12027 & 21455 \\
Belgium & 1652 & 3558 & 5093 & 7399 & 7741 & 8541 & 20745 \\
Switzerland & 3401 & 3941 & 5210 & 6278 & 7653 & 6829 & 10524 \\
Canada & 71 & 79 & 77 & 328 & 457 & 446 & 9312 \\
France & 1410 & 2034 & 2620 & 2990 & 3348 & 4503 & 8899 \\
Sweden & 859 & 1353 & 2557 & 2794 & 4405 & 4522 & 8713 \\
Ireland & 34 & 310 & 401 & 538 & 2634 & 3443 & 8457 \\
Netherlands Antilles & 3335 & 4263 & 4865 & 5304 & 5365 & 5511 & 7194 \\
& & & & & & & 85.8 \\
Share of top 10 in total & 86.7 & 86.9 & 86.5 & 85.5 & 85.5 & 58.9 \\
Share of EU in total & 38.0 & 43.7 & 45.4 & 48.8 & 52.1 & 52.6 & 53.9 \\
\hline
\end{tabular}

Source: DNB (2000b)

Table 3.2 gives an overview of the 1999 FDI stocks for all countries reported by the Dutch Central Bank, ordered alphabetically. We see large differences between stocks from individual countries. Again, it is obvious that the United States, the United Kingdom, Belgium, Germany, France, and Switzerland are the largest inward investors in the Netherlands. Japan is still a relatively small investor, with total stock amounting to 2989 million Euro in 1999. However, compared to other Asian countries, it has considerable investments in the Netherlands. In this study we attempt to explain the different investment positions by testing hypotheses related to the market, trade, distance, cost, and environmental determinants of Dutch inward FDI.

\footnotetext{
${ }^{2}$ Intra-EU investments have increased significantly. With the initiation of the Internal Market Programme (aimed at the removal of all remaining non-tariff barriers in goods, services, and assets between member countries), firms based in EU saw opportunities for asset-augmenting and strategic asset seeking FDI, particularly in finance, banking and insurance, telecommunications, and business services. Furthermore, MNEs saw opportunities to exploit economies of scale and scope within the borders of the European Union (Dunning 1997a, 1997b).
} 
Table 3.2 FDI Stock in the Netherlands by country, 1999

(Million EUR at year-end)

\begin{tabular}{|l|r|l|r|l|r|}
\hline Country & Stock & Country & Stock & Country & Stock \\
\hline Aruba & 833 & Hong Kong & 113 & Russia & 24 \\
Australia & 635 & Indonesia & 165 & Saudi Arabia & 37 \\
Austria & 768 & Ireland & 8457 & Singapore & 536 \\
Belgium & 20745 & Israel & 409 & Spain & 484 \\
Brazil & 129 & Italy & 570 & Sweden \\
Canada & 9312 & Japan & 2989 & Switzerland & 8713 \\
Denmark & 837 & Luxembourg & 3384 & Taiwan & 10524 \\
Finland & 1466 & Malaysia & 15 & Turkey & 100 \\
France & 8899 & Norway & 1155 & United Kingdom & 234 \\
Germany & 21455 & Portugal & 235 & United States & 27242 \\
Greece & 16 & & & 47911 \\
\hline
\end{tabular}

Source: DNB (2000b)

\subsection{Brief literature review}

Several theories have been developed to explain FDI. However, one overall theory that takes all different aspects of MNE activities into account to this date, unfortunately, does not exist. The complexity of the issues involved makes researchers focus on parts of MNE behaviour. Several authors have provided good overviews of the most prevalent viewpoints (Agarwal 1980, Dunning 1993, Caves 1996). Frequently, the existing theories on FDI are grouped in five categories based on their underlying methodological foundations: (a) industrial organisation, (b) corporate investment theory, (c) strategic theory, (d) eclectic paradigm, and (e) portfolio theory (Aristotelous and Fountas 1996).

The theory of industrial organisation (IO) suggests that firm-specific characteristics such as management skills, economies of scale, and product technology - provide firms with oligopolistic power that causes market imperfections (Buckley and Casson 1976, Kindleberger 1969). Internalisation theory later extended this theory by explaining that firms internalise their advantages within the boundaries of the firm to reduce uncertainty and to appropriate the resulting profits.

IO and internalisation theories lack a description of the factors that influence the choice for a particular host economy. This shortage is covered by corporate investment theory that emphasises the importance of locational determinants, such as the size and growth of the host market, factor prices for the most important resources, and the need to circumvent existing trade protection.

What is lacking in this perspective is the long-term intention of FDI. What does the MNE want to achieve with its foreign operations? Strategic theory emphasises these intentions, stressing the need to defend existing foreign markets against competitors or the desire to gain and maintain a strategic source of supply. 
Dunning $(1981,1993)$ recognised that it is impossible to find an all-embracing theory of FDI. He therefore presents a framework that is a blend of the above approaches, labelled the eclectic paradigm of international production. A firm needs ownership-specific advantages that are internalised within the firm but exploited at foreign locations (as opposed to licensing to another firm abroad), taking advantage of location-specific factors in the host economy. Over the years, many researchers have contributed to and extended this framework (see for example a special issue of the International Journal of the Economics of Business on the eclectic paradigm in a globalising world, Vol. 8, 2001). The fifth group of FDI theories studies FDI as part of a portfolio of domestic and international investments. A diversified portfolio can reduce the risk of fluctuations in rates of return on capital. FDI depends largely on international differences in interest rates, profit rates, and other measures of return on capital. An important weakness of this approach is that it explains international portfolio diversification, but not FDI per se.

Our focus in this present study is on the attractiveness of a particular host country to foreign investors. Therefore, we restrict ourselves to one aspect of MNE activity and emphasise the locational determinants of FDI at the level of the country. Several empirical studies have dealt with the determinants of FDI in a range of countries or regions from a macroeconomic perspective. The most commonly tested determinants include market size, per capita income, costs of borrowing, wage rates, stock market return rates, bilateral trade, tariffs, exchange rates, strikes, country risk, geographic distance, and cultural distance. Table 3.3 gives an overview of the most important results of a selection of these studies. We have included only those variables that were significant in one or more studies in the table.

Grosse and Trevino (1996) have studied the factors that contribute to the explanation of inward FDI in the United States for the period 1980-1991. Using pooled cross-sectional time series regressions for twenty-three home countries, they find that both home country's exports to the US and home country market size have a significant positive influence on inward FDI (measured by total inflow or total sales of foreign affiliates) in the US. Significant negative influences include home country's imports from the US, the cultural and geographic distances between the US and the MNE home country, and the exchange rate. Furthermore, Grosse and Trevino find weak evidence confirming that political risk was an important contributor to US FDI (significant in only 2 out of 6 regressions). They find no significant influence of the difference in cost of borrowing or rate of return between the home country and the US.

Many recent empirical studies on the determinants of FDI inflows have focused their attention on China, newly-industrialising Asian economies, and the Pacific region. Liu et al. (1997) estimate an error-components model $^{3}$ of the determinants of pledged (realised) annual FDI flows in China using pooled cross-section and time series data for 22 (17) home countries during the period 1983-1994 (1984-1994). The results indicate that for

\footnotetext{
${ }^{3}$ Liu et al. (1997) use this model because their initial F-tests showed that the slopes and intercepts were not homogeneous across all countries in the study and OLS was therefore inappropriate for their sample.
} 
both pledged and realised FDI, annual inflow is positively influenced by real exports and imports (representing economic integration between the home and the host country) and relative real exchange rates ${ }^{4}$. Relative wage rate is a significant negative influence on inward FDI in China. In the case of pledged FDI relative market size (measured by relative real GDP) has a significant positive influence on FDI and total cultural difference has a significant negative influence on annual FDI inflows. They find no significant evidence that relative borrowing costs, country risk, and geographic distance influence inward FDI flows.

Wang and Swain (1995) compare the determinants of inward FDI in China with those in Hungary, considering that both economies can be seen as transition economies. They analyse the period 1978-1992. Their results support the hypotheses that FDI is determined positively by the host country market size and the growth of the home country market. FDI is negatively influenced by the cost of capital and political instability. In the case of China, exports from the host economy and tariffs also exert a negative influence on FDI while the low wage rate has a positive influence on FDI flows. The negative sign for tariffs is surprising considering that it indicates that high tariffs are discouraging local investments instead of motivating firms to avoid the tariffs by locally produced goods. The effect of the exchange rate is significant but differently signed in China and Hungary. For Hungary the rapid exchange rate fluctuations and overdevaluation of the local currency together with rapid import liberalisation may explain the unexpected result for the exchange rate variable.

Ferris et al. (1994) study the determinants of FDI flows to Latin America. Many of the Latin American countries in their sample ${ }^{5}$ have experienced periods of state intervention and economic regulation interrupted by periods of economic liberalisation. This high degree of political uncertainty is considered a deterrent to most Western investors. Several East European countries are going through a similar transition process as the Latin American economies. By analysing the determinants of inward FDI in Latin America, Ferris et al. (1994) hope to contribute to the design of policies that will stimulate FDI in Romania, to help the transition process from a Soviet nation to a marketdriven economy. Their results indicate that the FDI flows are positively influenced by the host country market size, infrastructure, and trade relations. They therefore emphasise the strong and decisive role of the government as a facilitator of FDI inflows.

Love and Lage-Hidalgo (2000) analyse the determinants of investment flows from the United States to Mexico between 1967-1994. They find that cheap labour and a large host market size and market growth positively influenced the investment inflows in Mexico.

\footnotetext{
${ }^{4}$ This effect opposes the effect in the Grosse and Trevino (1996) study due to the measurement of the exchange rate. Grosse and Trevino measure the exchange rate as foreign currency to the Dollar, whereas Liu et al. measure the exchange rate as chinese real Ren-Min-Bi to the real home country currency.

${ }_{5}^{5}$ Ferris et al. (1994) include Argentina, Bolivia, Brazil, Chile, Colombia, Ecuador, Mexico, Paraguay, Peru, Uruguay, and Venezuela in their analysis.
} 
Table 3.3 Overview of the findings of empirical studies on the macro-economic determinants of FDI flows

\begin{tabular}{|c|c|c|c|c|c|c|c|c|c|c|c|c|}
\hline & 1 & 2 & & 3 & & 5 & 6 & 7 & 8 & 9 & 10 & 11 \\
\hline Variable ${ }^{*} \quad$ Country & US & China & China & Hungary & $\begin{array}{c}\text { Latin } \\
\text { America }\end{array}$ & Mexico & Australia & EEC & EEC & & $\mathrm{EU}$ & Spain \\
\hline $\begin{array}{l}\text { Trade variables } \\
\text { Imports from host } \\
\text { Exports to host } \\
\text { Tariffs } \\
\text { Openness of the economy }\end{array}$ & $\begin{array}{l}- \\
+\end{array}$ & $\begin{array}{l}+ \\
+\end{array}$ & $\begin{array}{l}- \\
-\end{array}$ & $\begin{array}{l}\text { NS } \\
\text { NS }\end{array}$ & $\begin{array}{l}- \\
+\end{array}$ & & - & - & + & $\begin{array}{l}+ \\
+\end{array}$ & NS & - \\
\hline $\begin{array}{l}\text { Market variables } \\
\text { Home country GDP } \\
\text { Host country GDP } \\
\text { Relative GDP } \\
\text { Home GDP growth } \\
\text { Host country GDP growth } \\
\text { Growth rate differential } \\
\text { Absolute change host GDP }\end{array}$ & + & + & $\begin{array}{l}+ \\
+ \\
\text { NS }\end{array}$ & $\begin{array}{l}+ \\
+ \\
\text { NS } \\
+ \\
\end{array}$ & + & + & & + & + & $\begin{array}{l}+ \\
+ \\
+ \\
+\end{array}$ & $\begin{array}{l}+ \\
+\end{array}$ & + \\
\hline $\begin{array}{l}\text { Distance variables } \\
\text { Geographic distance } \\
\text { Cultural distance }\end{array}$ & - & $\begin{array}{l}\text { NS } \\
- \\
\end{array}$ & & & & & & & & & & \\
\hline $\begin{array}{l}\text { Cost variables } \\
\text { Cost of funds }{ }^{\cdots . .} \\
\text { Relative rate of return } \\
\text { Exchange rate } \\
\text { Wage rate } \\
{ }^{*}\end{array}$ & $\begin{array}{l}\text { NS } \\
\text { NS } \\
-\end{array}$ & $\begin{array}{l}\text { NS } \\
+ \\
- \\
\end{array}$ & $\begin{array}{l}- \\
+ \\
+ \\
\end{array}$ & $\begin{array}{c}- \\
- \\
\text { NS }\end{array}$ & & $\begin{array}{l}- \\
+ \\
+ \\
\end{array}$ & $\begin{array}{l}+ \\
+ \\
+\end{array}$ & & & $\begin{array}{l}+ \\
- \\
\end{array}$ & + & NS \\
\hline $\begin{array}{l}\text { Environmental variables } \\
\text { Political risk }{ }^{* .} \\
\text { Inflation } \\
\text { Infrastructure } \\
\text { Industrial disputes }\end{array}$ & + & NS & - & - & $\begin{array}{l}\text { NS } \\
+\end{array}$ & & $\begin{array}{l}- \\
+\end{array}$ & & & & & - \\
\hline $\mathrm{R}^{2}$ of study ${ }^{\#}$ & $\begin{array}{l}.55- \\
.60 \\
\end{array}$ & $\begin{array}{l}.66- \\
.75 \\
\end{array}$ & $\begin{array}{l}.91- \\
.95\end{array}$ & $.77-.93$ & .38 & $.34-.68$ & $.37-.49$ & $\begin{array}{l}.88- \\
.93\end{array}$ & $\begin{array}{l}.75- \\
.97 \\
\end{array}$ & $\begin{array}{l}.37- \\
.60\end{array}$ & $\begin{array}{l}.15- \\
.49 \\
\end{array}$ & $.80-.91$ \\
\hline
\end{tabular}




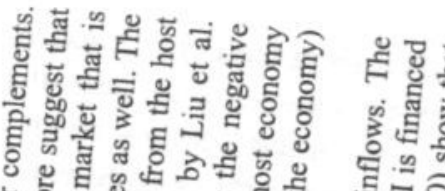

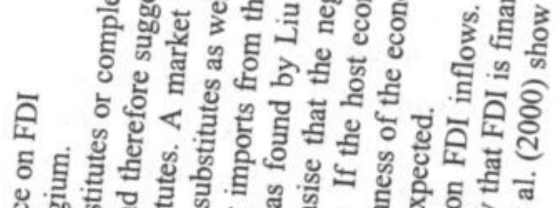

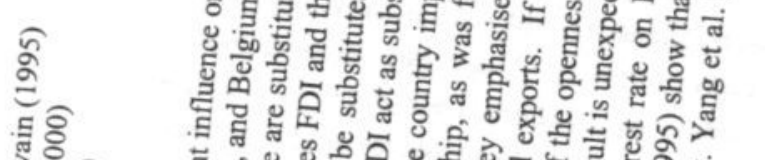

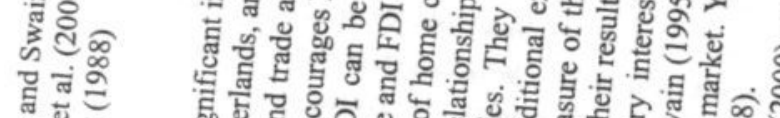

ता

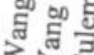

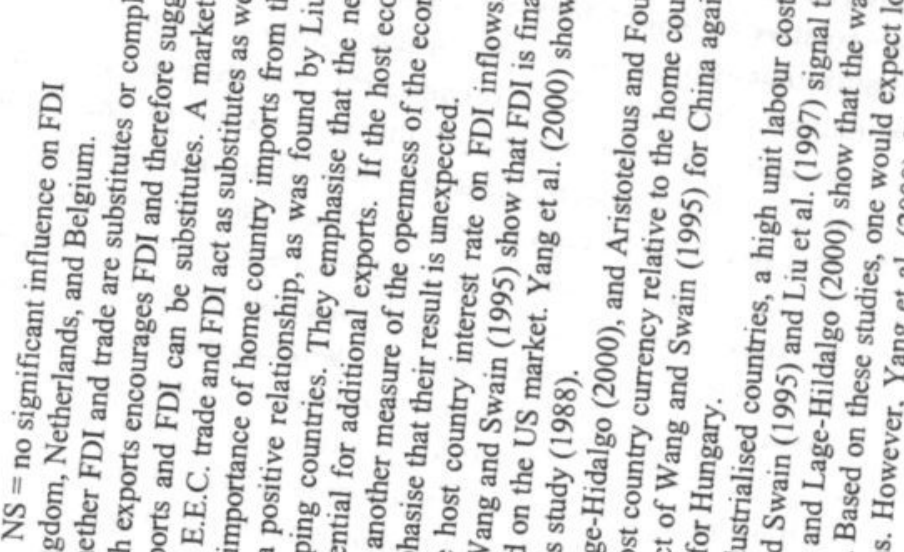

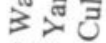

II II II

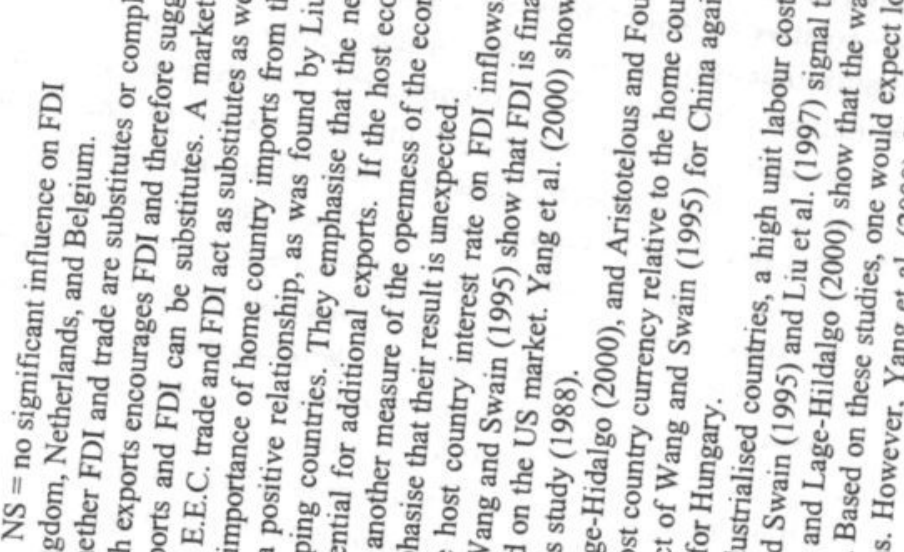

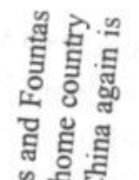

ำ

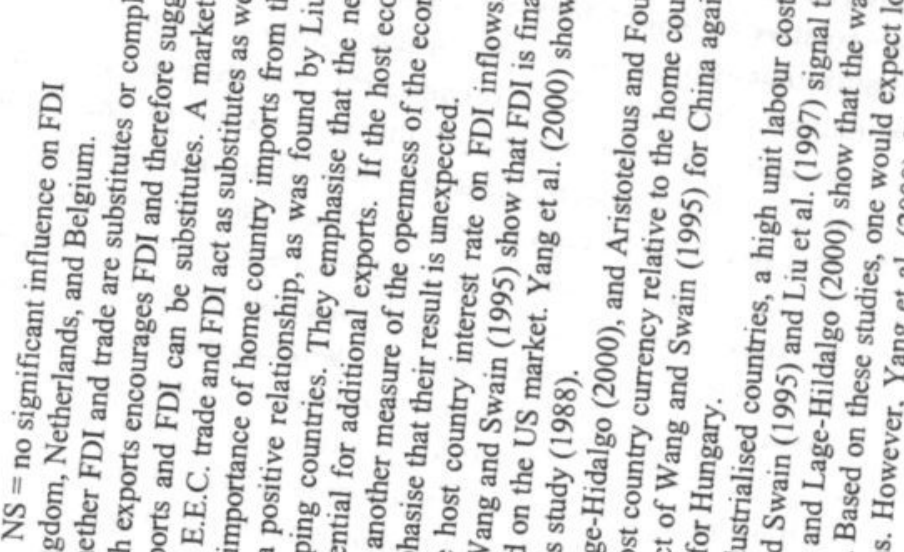

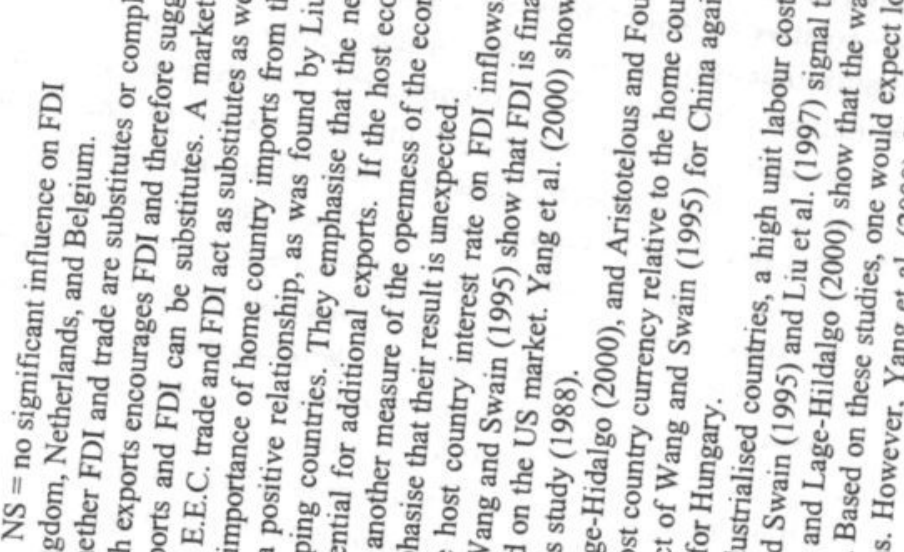

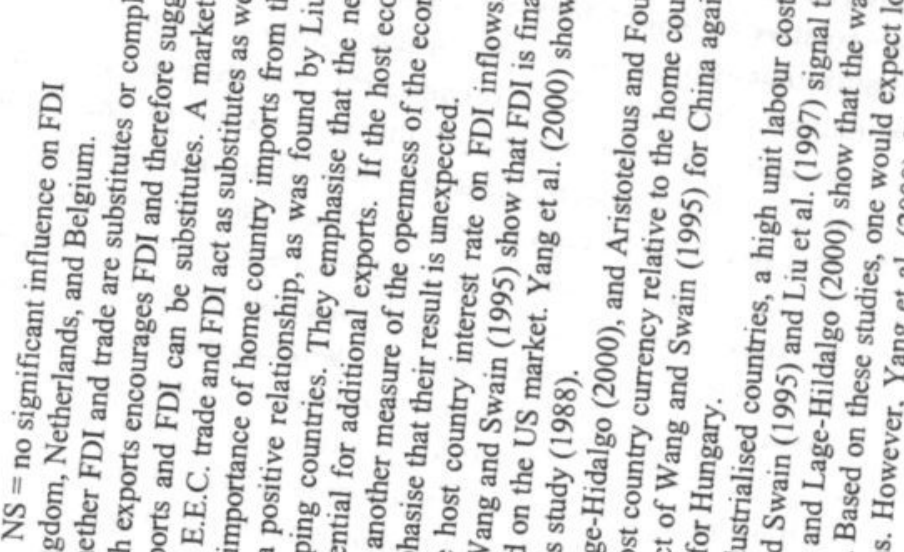

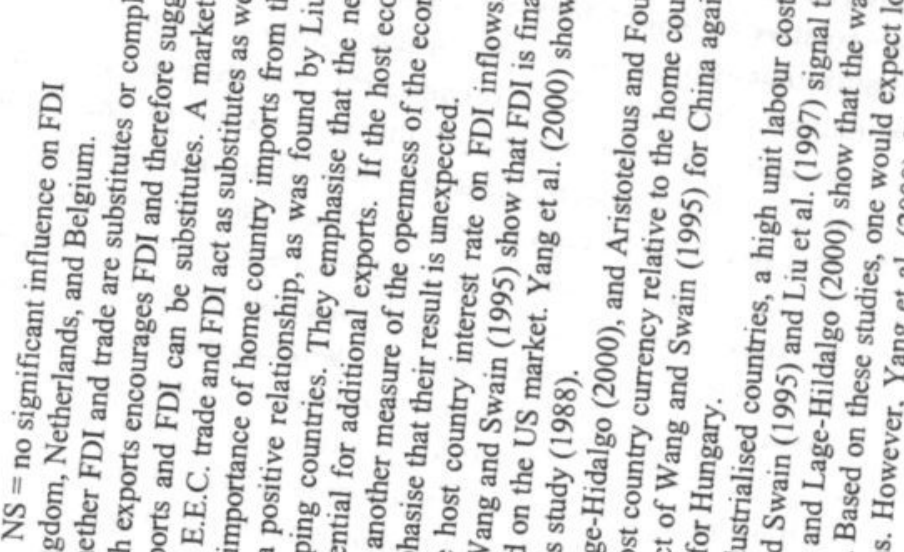

m 0 a

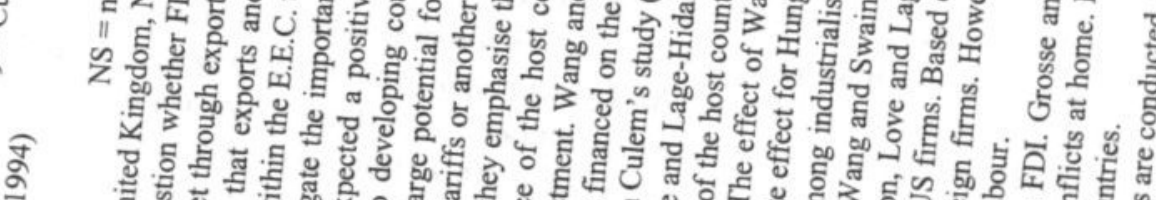

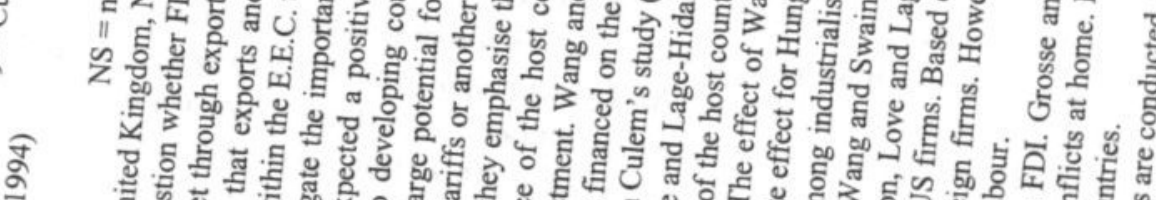

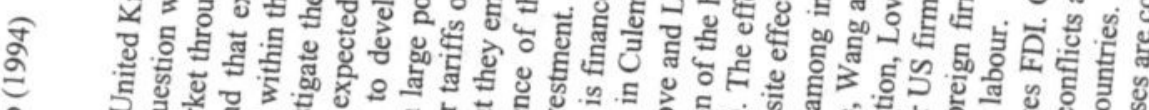

○ิ

담

앙 항

좀을

ล

ลิญ 듀

임ㅉㅁ윰

तं प्ल

त्

ปั ญั

-1ట్

II II ||

$\sim \sin =$

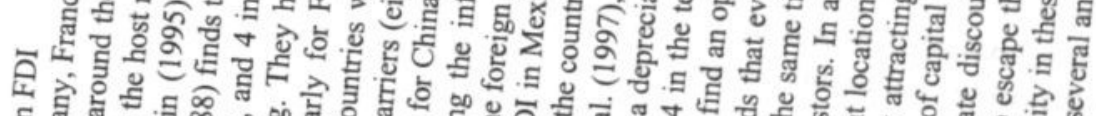

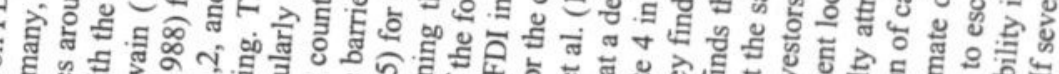

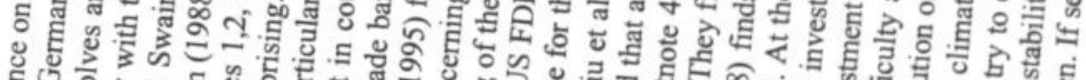
过

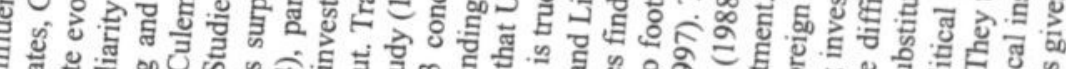

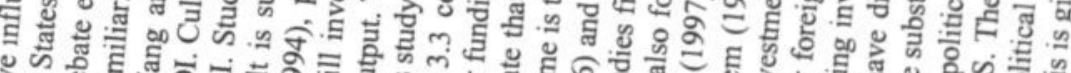

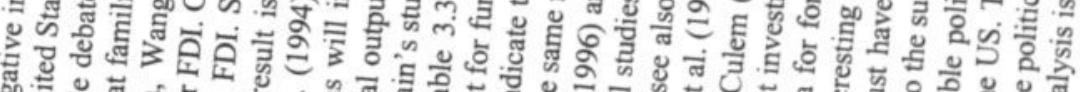

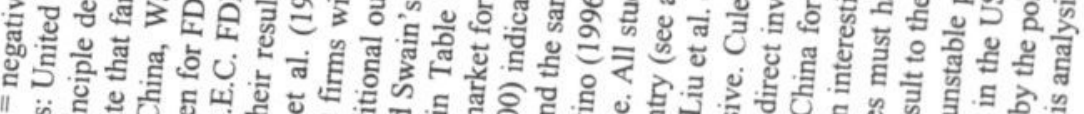

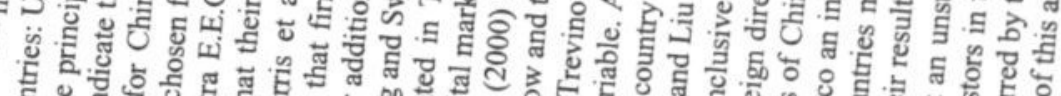

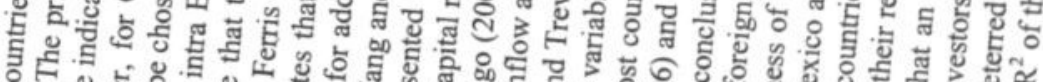
Oี

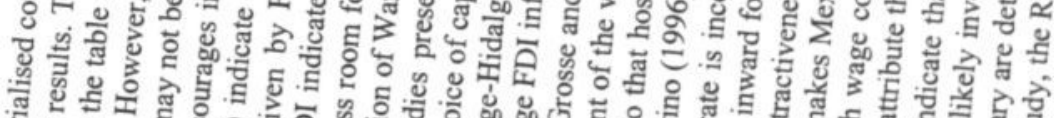
ล 2.

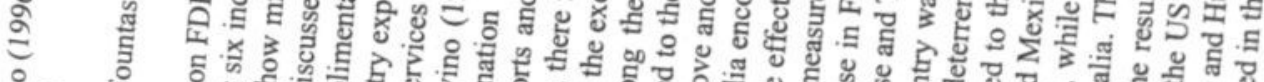

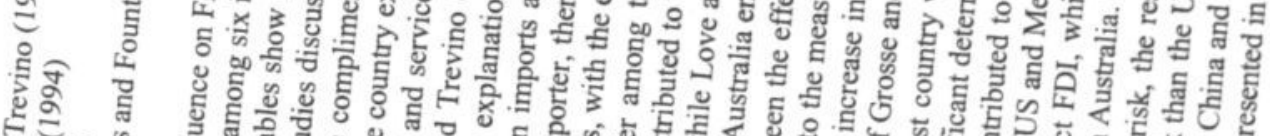

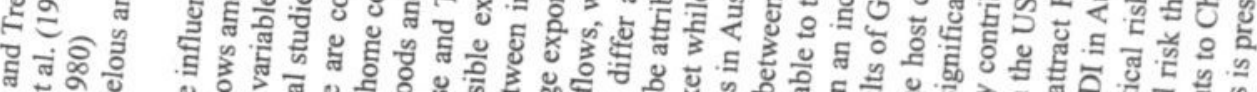

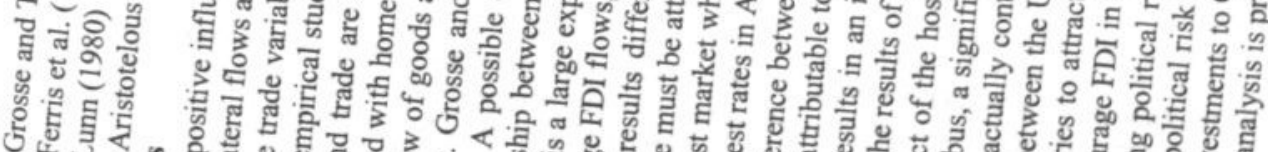

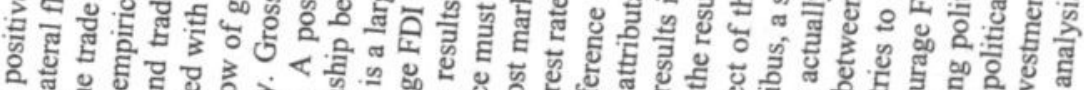

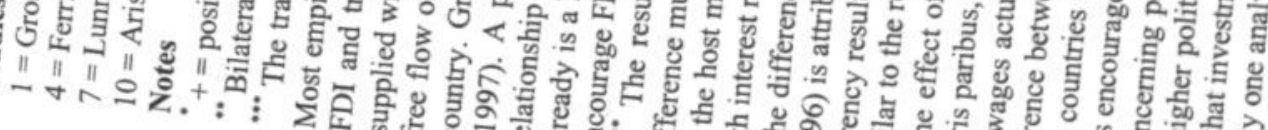
$\forall \wedge={ }^{+}: \vdots$ ¿ 
The result for capital costs suggests that FDI from the US to Mexico decreases as the US cost of capital rises relative to that of Mexico. This result suggests that FDI is financed on the home market and increasing capital costs in the US then result in lower FDI levels. Love and Lage-Hidalgo (2000) find that exchange rate movements influence the timing of the investment decision. A depreciation of the peso tends to encourage US direct investment in Mexico (by making assets cheaper), but with a short time lag.

Yang et al. (2000) investigate the determinants of Australian inward FDI for the period September 1984 till March 1994, using aggregated quarterly time-series data. They estimate a model that tries to explains FDI inflow in terms of a short-term interest rate, real GDP, the exchange rate, trade, labour disputes, wages costs, and inflation. They find that FDI inflow is positively related to the interest rate in Australia, reflecting the fact that higher interest rates in the host economy make foreign investment more attractive. They also find evidence that FDI is used to circumvent trade barriers. Openness of the economy (measured as total trade as a percentage of GDP) is negatively related to FDI inflow. High inflation turns out to discourage FDI inflow. Surprisingly, they find that high wage costs increase FDI. They contribute this effect to the substitution of capital for (expensive) labour, resulting in an increase of FDI inflow. Furthermore, they also find the counter-intuitive result that industrial disputes encourage FDI inflow in Australia. They suspect that industrial disputes result in higher labour costs and again to the substitution of capital for labour.

Several studies have focused on the determinants of FDI inflows in the European Union. Lunn (1980), using annual data for the 1957-1970 period, finds that host country market size and growth rate positively influence US FDI into the European Union (at that time the European Economic Community, E.E.C.). Growth of the host economy is particularly influential when it is larger than anticipated and accelerating. Existing trade barriers (proxied by exports from the home country) also were an important determinant of FDI inflow from the US. An increase in trade barriers in the host economy (equalling a reduction of export opportunities for firms in the home country) induces factor movements of firms trying to circumvent these trade barriers.

Scaperlanda and Balough $(1983)^{6}$ have also analysed the inflow of US FDI in the E.E.C., using data for 1953-1977. They find that FDI inflow in the six original members of the E.E.C. was positively determined by the host market size and host market growth. Furthermore, they find that tariff discrimination by the E.E.C. against the US also resulted in FDI inflows. US firms try to get around the trade barriers by investing in the E.E.C.

\footnotetext{
${ }^{6}$ For US foreign investments not only total FDI inflows but also aggregate sales data and aggregate plant and equipment expenditures are available. Scaparlanda and Balough (1983) therefore also tested the determinants of the US plant and equipment expenditures in the E.E.C. The same relationships between the dependent and independent variables were found, only stronger. When using host country sales instead of GDP as a proxy for the host country market size, they again find a strong positive relationship between market size and FDI inflow.
} 
Culem (1988) investigates the locational determinants of FDI by examining the bilateral FDI flows among six industrialized countries (United States, Germany, France, Belgium, the United Kingdom, and the Netherlands) ${ }^{7}$. Over the period 1969-1982, he finds that on average, the size and growth rate of the host country (positive) as well as its unit labour costs (negative) all have a significant influence on the amount of inward FDI. Furthermore, he finds that firms will try to circumvent trade barriers by FDI. Culem (1988) also investigates the FDI flows among groups of countries (US FDI in the E.E.C., E.E.C. FDI in the US, and intra E.E.C. FDI). Most effects remain the same. Within the E.E.C. he finds that exports between the countries have a tendency to dampen FDI initiatives in the same direction. Since all trade restrictions have been abolished between those countries, foreign market demand can also be supplied through exports, making FDI unnecessary.

Aristotelous and Fountas (1996) have tested specifically whether the acceptance of the Single European Act has influenced new EU inflows of FDI from the US and Japan. Using annual data for the period 1983-1992, they find strong evidence in favour of a single market effect. The anticipation of a larger market size due to a barrier free European market has lead to an increase in FDI. Furthermore, their results show that FDI flows in the EU also depend on market size and the real exchange rate. A large host market allows a foreign firm to achieve economies of scale in production and therefore increases FDI flows to that country. A depreciation of the host country's currency makes domestic assets cheaper, leading to an increase in capital inflows to that host country.

One study has investigated the determinants of FDI in an individual European host country. Bajo-Rubio and Sosvilla-Rivero (1994) have tested the determinants of FDI in Spain over the 1964-1989 period $^{8}$. They find that Spain's EU-membership (from 1986 onwards) resulted in a significant new inflow of FDI due to the expectations of a larger market size. They also find that a stable and growing economy is a necessary condition for a country to attract foreign investors. Inflation deters foreign investors while existing trade barriers encourage foreign investment flows. Labour costs and costs of capital have no significant influence of FDI flows to Spain.

Our understanding of this body of the literature suggests that the macro-economic variables influencing inward FDI in a host economy (presented in Table 3.3) can broadly be classified in five groups: 1) trade relations, 2) market and demand-related variables, 3) environment, 4) distance, and 5) cost and equilibrium variables ${ }^{9}$. This classification

\footnotetext{
${ }^{7}$ Culem's sample pools cross-section and chronological annual data. It covers 30 ordered pairs of countries over 14 years, which raises the sample to 420 observations when all bilateral FDI flows are simultaneously considered. Each observation thus pertains a bilateral relationship (from country $a$ to country $b$ or vice versa). The choice of countries and years is determined by the availability of data.

${ }^{8}$ Bajo-Rubio and Sosvilla-Rivero (1994) use cointegration analysis since their data consist of a nonstationary time series.

${ }^{9}$ Given the high explanatory power of these variables in previous studies, we have decided not to include additional variables in this present study on the Netherlands.
} 
results in the conceptual model of the determinants of inward FDI presented in Figure 3.1.

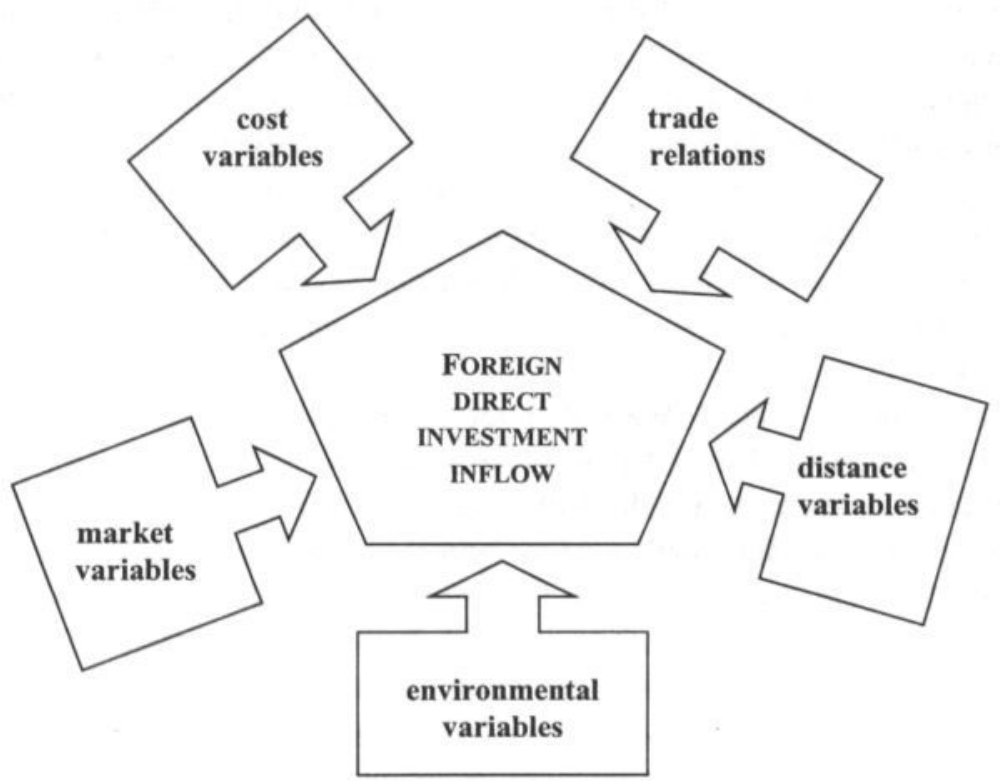

Figure 3.1

Inward FDI Determinants

\subsection{Hypotheses}

Most studies have tested a sub-set of the determinants of inward FDI identified in Figure 3.1 and not all five groups of variables together. Furthermore, so far no empirical study has considered the determinants of inward FDI flows in the Netherlands. This study attempts to fill this gap. We consider the five groups of variables as specified in our conceptual model. In this section, for each group of potentially contributing factors, we hypothesise their relationship with inward FDI and discuss the reasons for including them in our model. The main potential determinants of Dutch inward FDI are:

1. Trade relations: exports from home to host countries normally precede FDI, with the firm 'learning' about overseas market opportunities initially through exports before engaging in FDI (Narula and Wakelin 2001). Exports from the home country can serve as a platform for future expansion in a host market (Kogut and Chang 1996). They are therefore often included as an indicator of experience with the host country market. A high level of imports in the host economy signals a high penetration by foreign firms that 
may start off by exporting to the host economy and later switch to FDI once they have established a foothold in that area (Billington 1999). Given the considerable importance of trade for the Dutch economy (see Chapter two), we expect this variable to be of significant importance for the explanation of the attractiveness of the Netherlands. As found in previous studies (Ajami and BarNiv 1984, Grosse and Trevino 1996, Liu et al. 1997), we expect that the amount of existing trade between the Netherlands and a particular home country will have a strong relation to the amount of FDI inflow from that country. Because firms can use both trade and FDI to serve foreign markets, we expect trade and FDI to be complementary. We expect greater exports from the home to the host country to be linked with greater FDI. Exports to the Netherlands may be used to supply a Dutch affiliate with a full or partial product line from the home country. Similarly, exports from the Dutch affiliate to the parent's home country may be used to supply the parent in the home country with inputs and/or the home country market with products. Moreover, more bilateral trade implies a higher level of integration between the home and host country, enabling the foreign firms to obtain more information on the market and investment opportunities in the host location. We therefore suggest the following hypothesis $^{10}$ :

H1: The greater the amount of existing trade between the Netherlands and a particular home country, the greater the FDI flow from that country into the Netherlands

2. Market- and demand related variables: these variables focus on the role of demand conditions in the home and host market and their implications for economies of scale and scope (Narula and Wakelin 2001). We expect the market size of the Netherlands to be relatively unimportant. Within Europe, it is one of the smaller countries, making it relatively unattractive as a consumer market for foreign products. We therefore focus our attention on the size of the home country market. Following Grosse and Trevino (1996) we expect the size of the home country market to be positively related to the amount of FDI in the Netherlands. Larger home countries may have more local firms that may consider international expansion through FDI. GDP is therefore used as a proxy for the number of firms that could pursue international expansion (Grosse and Trevino 1996) and may choose to supply Dutch demand with locally produced goods. Furthermore, large home country demand results in large sales and perhaps profits that facilitate the financial burden of more/new (foreign) investments. These expectations can be summarised as:

H2: $\quad$ The larger the home country GDP, the greater the FDI flow from that country into the Netherlands

\footnotetext{
${ }^{10}$ Successive rounds of GATT-negotiations and the progressive reduction of tariffs and quota in the European unification process have made the Netherlands a very open economy. We therefore do not include a measure for trade barriers in this present study.
} 
If the home country is large in terms of population, we expect a negative influence on FDI flows to the Netherlands. A large customer base in the home country makes it less urgent to expand to another market to achieve the necessary economies of scale in production. We therefore propose the following hypothesis:

\section{H3: The larger the home country population, the smaller the FDI flow from that country into the Netherlands}

Furthermore, we also consider the differences in GDP growth rate between home countries and the Netherlands. If the host country market grows more quickly than the home country market, we expect the host country market to be more attractive for foreign investors (Culem 1988). MNEs considering the Netherlands for the establishment of an affiliate will have positive expectations of the potential sales when the Dutch economy is growing rapidly. We therefore suggest the following hypothesis:

H4: The larger the positive difference in GDP growth between the Netherlands and the home country, the greater the FDI flow from that country into the Netherlands

3. Environmental variables: these variables capture the effect of the overall political and economic environment in the home and host country in which the MNE would have to operate ${ }^{11}$. Close political and economic relationships between two nations should encourage FDI flows, while conflictive events should have a negative effect on FDI (Tallman 1988). Furthermore, seeking to escape home country risks may encourage firms to start activities in more stable economies (Grosse and Trevino 1996, Liu et al. 1997). Conflicts at home may result in a national environment that threatens private investment and produces an increase in outward direct investment (Tallman 1988). Particularly MNEs coming from countries that have a higher degree of internal political, economic, or social instability may be expected to choose the Netherlands for FDI. We expect that the higher the degree of home country risk in relation to the degree of risk in the Netherlands, the higher will be inward FDI in the Netherlands. If the opposite situation occurs and risk in the Netherlands is higher than at home, FDI will be discouraged (Ferris et al. 1994)

$"$ We include both political risk and inflation as environmental variables in this study. Other environmental variables tested in previous studies include infrastructure (Ferris et al. 1994) and industrial disputes (Yang et al. 2000). These variables were not included in our present study for the following reasons. Infrastructure is measured by the number of commercial vehicles used in a country (Ferris et al. 1994). In the case of the Netherlands, the ease of reaching the European market from any location in the Netherlands is mentioned as an important infrastructural asset (NFIA 1997c). The difficulty in measuring this aspect of transportation makes us exclude this variable. Industrial disputes are not very common in the Netherlands. In 1999, only 24 short labour disputes occurred involving 59000 labourers with the biggest one in education and not in the manufacturing industries (Kuijpers 2001). We therefore chose not to study this environmental variable. 
because most MNEs tend to avoid uncertainty and will therefore be more inclined to go to areas that are characterised by relative stability than by chaos.

H5: The greater the political risk of the home country compared to the Netherlands, the greater the FDI flow from that country into the Netherlands

In addition to political risk, inflation is often used to capture the stability of macroeconomic policy. Following Bajo-Rubio and Sosvilla-Rivero (1994), we consider high inflation to be a result of an unstable economic system, the presence of internal political pressures, and the unability to balance the budget. A market characterised by these problems is an unattractive location for foreign investors. We therefore expect FDI flows to be deterred when inflation in the host economy is larger than in the home country.

H6: The larger the inflation rate in the home country compared to the inflation rate in the Netherlands, the greater the FDI flow from that country into the Netherlands

4. Distance variables: the distance between the host and the home country may contribute to the explanation of the flow of FDI to a host economy. If the distance is larger, it is more difficult for firms to acquire the necessary information about the host market. Furthermore, managing an affiliate at a greater distance may involve larger costs. We distinguish between geographic distance and cultural distance. We expect that the larger the geographic distance between the home country and the Netherlands, the smaller will be inward FDI from that home country to the Netherlands. Similarly, the larger the cultural distance between the home country and the Netherlands, the larger the costs of managing the affiliate and therefore the smaller the foreign investments made by firms from this home country in the Netherlands. We suggest the following hypotheses:

H7: The greater the cultural distance between the home country and the Netherlands, the smaller the FDI flow from that country into the Netherlands

H8: The greater the geographical distance between the home country and the Netherlands, the smaller the FDI flow from that country into the Netherlands

5. Cost and equilibrium-related factors: these relate to the cost of production in the host market compared to those in the home country. Several theories support the notion that FDI is a way of dealing with market disequilibrium. Foreign markets will then attract 
FDI until the equilibrium is established again. Kindleberger (1969) already asserts that for direct investments to thrive, there must be some imperfection in the markets for goods or factors, or some interference in competition by governments or by firms. This interference does result in separate markets where competition is less intense which can give firms the opportunity to achieve higher profits.

Hypothesis nine is related to disequilibrium in the international cost of borrowing. FDI is generally financed in the home country. The higher the cost of borrowing in the Netherlands compared to the home country's cost of borrowing, the more cost competitive foreign firms are compared to local firms in the Netherlands (Liu et al. 1997). This enables foreign firms to enter the Dutch market, and thus increases their expected investment. Therefore, the higher the ratio of host country borrowing costs to the home country costs, the larger the inward FDI in the host country (Aliber 1970, Grosse and Trevino 1996, Liu et al. 1997, Yang et al. 2000).

H9: $\quad$ The lower the cost of borrowing in the home country versus that in the Netherlands, the greater the FDI flow from that country into the Netherlands

Firms may also consider FDI to lower their manufacturing costs (Liu et al. 1997). As labour costs are an important part of total costs, especially in labour intensive industries, firms may consider locating new affiliates in host countries that have relatively lower labour costs ${ }^{12}$. We therefore suggest the following hypothesis:

H10: The higher the wage rate in the Netherlands compared to the wage rate in the home country, the lower the FDI flow from that country into the Netherlands

Disequilibrium can also occur in the capital market. Foreign firms will move to areas where the expected rate of return is higher. This flow of investments will then balance out the differences between the rates of return in home and host countries. We therefore expect that:

H11: The lower the expected rate of return in the home country compared to the expected rate of return in the Netherlands, the greater the FDI flows from that country into the Netherlands

Finally, disequilibrium can also occur in the currency valuation. A real depreciation of the host country currency favours foreign purchasers of host country assets and therefore may lead to an increase in inward FDI in the host country due to cheaper acquisition

${ }^{12}$ See also the discussion under $\bullet$ in Table 3.3. 
opportunities and relatively cheaper labour (Aristotelous and Fountas 1996). Kogut and Chang (1996) illustrate this fact for Japanese investments in the US. A real appreciation of the yen against the dollar resulted in an increase in foreign investment flows from Japan to the US. Japanese firms with strong exports to the US invest in distribution channels and established brand labels seek to preserve the value of those assets by shifting manufacturing investments into the US when changes in the exchange rate deteriorate their terms of trade. Our expectations can therefore be summarised by:

H12: The greater the revaluation of the home-country currency against the Dutch guilder, the greater the FDI flow from that country into the Netherlands

Figure 3.2. summarises the hypotheses presented in this section. So far no study has analysed the combined effect of these variables on the foreign investment inflows in the Netherlands.

Trade relations
H1: Trade
Market variables
H2: GDP
H3: Home country population
H4: GDP growth
Environmental variables
H5: Political risk
H6: Inflation
Distance variables
H7: Cultural distance
H8: Geographical distance
Cost variables
H9: Cost of borrowing
H10: Wage rate
H11: Rate of return
H12: Exchange rate

$(+)$

$(+)$

$(-)$

$(-)$

$(-)$

(+)

INWARD FDI

IN THE

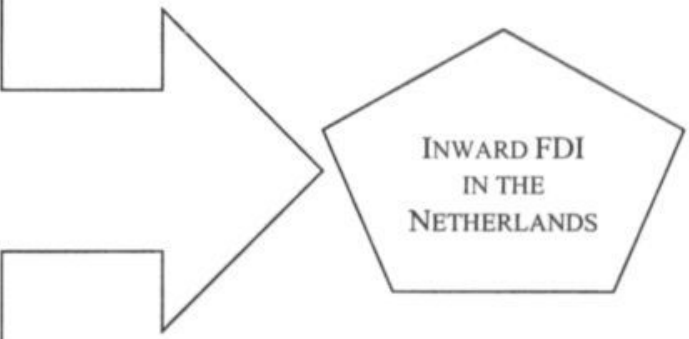

Figure 3.2

Hypothesised relationships

\subsection{The model}

The models generally used to evaluate these hypotheses are multivariate regression models. The data used in this study are pooled time-series, cross-section observations of foreign direct investment flows in the Netherlands from the various home countries during 1987-1999. We specifically study the period when the completion of the single market in Europe resulted in a significant upsurge in foreign investments in the European Union. 
For each year each country was one observation. Using data from 28 countries $^{13}$ (presented in Table 3.4) for 13 years ${ }^{14}$, we had a maximum number of observations of 364. However, missing values ${ }^{15}$ for the dependent variable (inflow of FDI in euro) reduces the maximum number of observations to 326 . Missing values for some of the independent variables further reduce the number of observations ${ }^{16}$.

Table 3.4 Overview of the countries in the study

\begin{tabular}{|l|l|l|}
\hline Australia & Hong Kong & Saudi Arabia \\
Austria & Indonesia & Singapore \\
Belgium & Ireland & Spain \\
Brazil & Israel & Sweden \\
Canada & Italy & Switzerland \\
Denmark & Japan & Taiwan \\
Finland & Malaysia & Turkey \\
France & Norway & United Kingdom \\
Germany & Portugal & United States \\
Greece & & \\
\hline
\end{tabular}

Ordinary Least Squares regressions (OLS) are usually used in studies on macro-economic determinants of FDI. OLS assumes constant slope and intercept parameters across time and country variations. For $\mathrm{N}$ countries and $\mathrm{T}$ time intervals, then, OLS assumes a homogeneous data set of $\mathrm{N}^{*} \mathrm{~T}$ observations. The basic model, based on the relationships expressed in the hypotheses, is:

FDI in the $\mathrm{NL}=\mathrm{f}$ (existing bilateral trade $[+]$; size of home country market $[+]$; GDP growth difference $[+]$; home country population $[-]$; relative political risk $[+]$; relative inflation rate $[-]$; cultural/geographic distance from the Netherlands $[-]$; relative cost of borrowing $[+]$; relative rate of return $[+]$; relative wage rate $[-]$; exchange rate $[+])$

\footnotetext{
${ }^{13}$ We do not consider the Netherlands Antilles investment flows. Some originally Dutch firms have moved their headquarters there for tax reasons only. Their investments in the Netherlands are registered as FDI. We however expect these investments to be motivated by other reasons than inflows from other foreign countries and therefore choose not to analyse these flows in this study. Luxembourg is excluded from the study because trade data are not reported for this country.

${ }^{14}$ The sample period is dictated by the data-availability of a sufficiently large group of home countries. Before 1987, DNB did not report detailed overviews of Dutch FDI inflows by home country.

${ }^{15}$ FDI inflow data are missing for several years for Turkey, Saudi Arabia, Taiwan, Malaysia, and Indonesia.

${ }^{16}$ For Saudi Arabia we have used the Hofstede data for Arab countries to measure the cultural distance between the Netherlands and Saudi Arabia.
} 


\subsection{Data and variables}

Table A1 in Appendix 3.1 gives an overview of the variables used in this model, their expected influence on FDI inflows in the Netherlands, and the sources that were used to collect the data. The dependent variable is measured by the real annual inflow of foreign direct investment in the Netherlands by home country, as given by De Nederlandsche Bank (DNB), the Dutch Central Bank ${ }^{17}$.

Most of the independent variables are measured simultaneously with FDI because the impacts of these factors are expected to occur either simultaneously with FDI (e.g. cultural and geographic distance) or with a lag of a few months or longer (exchange rate, bilateral trade, GDP). Because our analysis is explanatory rather than predictive, we mostly chose not to test various lag structures. We only tested one-year lags for GDP, Imports, Exports, and Population. We expect their influence to occur with at least a one year lag.

We limit our analysis to the period 1987 - 1999, considering only investments that occurred after the acceptance of the Single European Act (SEA). Aristotelous and Fountas (1996) found that the Single European Act (1987) had considerable influence on the inflow of FDI from the US and Japan to Europe. The commitment to complete a single market by eliminating all remaining barriers to intra-union trade and by providing for free movement of capital, goods, persons, and services by the end of 1992 resulted in a considerable increase in market opportunities and therefore to an inflow of FDI.

\subsection{Results}

The sample period and the data frequency are largely dictated by the data available for FDI. The regression analyses in this chapter are based on data generated from 28 countries over 13 years. Table 3.5 shows the results of testing the models under varying specifications in SPSS 9.0 for Windows.

Estimation A includes all variables for which we have hypotheses. However, the correlation matrix indicates high correlation among some of the included variables. Therefore the results of specification A may be biased and incorrect and have to be interpreted with caution. Collinearity among the variables results in variance inflation and model misspecification. We therefore calculated the variance inflation factors (vif) for all variables included in the regression. Generally a vif $<10$ is acceptable (Hair Jr. et al. 1998). We find strong collinearity among the trade variables imports (vif $=19.8$ ) and exports (vif $=17.5$ ). One way of solving this problem is to remove one of the variables from the model. Specification B and C therefore separately tests for the influence of either imports (specification B) or exports (specification C).

\footnotetext{
${ }^{17}$ DNB reports aggregated annual inflows for the Netherlands. Contrary to stock data, inflows are not reported by individual sector.
} 
Table 3.5 Regression results of FDI flows into the Netherlands

\begin{tabular}{|c|c|c|c|c|c|c|}
\hline Specification & A & B & C & D & E & $\mathrm{F}$ \\
\hline Constant & $\begin{array}{r}651.79 \cdots \\
(3.39)\end{array}$ & $\begin{array}{r}652.56{ }^{*} \\
(3.41)\end{array}$ & $\begin{array}{r}679.74 \times \\
(3.56)\end{array}$ & $\begin{array}{r}639.05^{*} \\
(3.36)\end{array}$ & $\begin{array}{r}375.81^{*} \\
(2.27)\end{array}$ & $\begin{array}{r}-442.45 \\
(-1.25)\end{array}$ \\
\hline a. Trade & & & & & & \\
\hline Exports & $\begin{array}{r}-5.37 \\
(-0.16)\end{array}$ & & $\begin{array}{r}35.21^{\cdots} \\
(3.69)\end{array}$ & & & \\
\hline Imports & $\begin{array}{l}58.72 \\
(1.25)\end{array}$ & $\begin{array}{r}51.57^{\cdots \cdots} \\
(3.91)\end{array}$ & & $\begin{array}{r}50.42 \cdots \\
(3.85)\end{array}$ & $\begin{array}{r}61.10^{\cdots} \\
(4.86)\end{array}$ & $\begin{array}{r}80.09^{\cdots} \\
(6.09)\end{array}$ \\
\hline b. Market & & & & & & \\
\hline Home GDP & $\begin{array}{c}1.10^{* . *} \\
(5.61)\end{array}$ & $\begin{array}{c}1.11 \cdots \\
(6.08)\end{array}$ & $\begin{array}{c}1.18 \times \\
(6.41)\end{array}$ & $\begin{array}{c}1.08^{\cdots *} \\
(6.05)\end{array}$ & $\begin{array}{c}0.67^{\cdots} \\
(5.33)\end{array}$ & \\
\hline Home population & $\begin{array}{r}-18.98^{\cdots} \\
(-4.05)\end{array}$ & $\begin{array}{r}-19.09^{\cdots} \\
(-4.13)\end{array}$ & $\begin{array}{r}-19.59^{\cdots} \\
(-4.20)\end{array}$ & $\begin{array}{r}-18.24 \\
(-4.07)\end{array}$ & $\begin{array}{c}-8.01 \cdots \\
(-2.76)\end{array}$ & \\
\hline GDP growth & $\begin{array}{l}-41.28 \\
(-1.31)\end{array}$ & $\begin{array}{l}-41.97 \\
(-1.35)\end{array}$ & $\begin{array}{l}-46.71 \\
(-1.49)\end{array}$ & $\begin{array}{l}-39.62 \\
(-1.29)\end{array}$ & $\begin{array}{l}-17.00 \\
(-0.66)\end{array}$ & $\begin{array}{l}-42.18 \\
(-1.24)\end{array}$ \\
\hline $\begin{array}{l}\text { GDP per capita } \\
\text { c. Environment }\end{array}$ & & & & & & $\begin{array}{r}43.81^{\cdots} \\
(3.17)\end{array}$ \\
\hline Political risk & $\begin{array}{l}-15.30 \\
(-1.63)\end{array}$ & $\begin{array}{c}-15.31^{\circ} \\
(-1.64)\end{array}$ & $\begin{array}{l}-15.49^{\circ} \\
(-1.65)\end{array}$ & $\begin{array}{l}-15.84^{\circ} \\
(-1.70)\end{array}$ & $\begin{array}{r}-5.09 \\
(-0.71)\end{array}$ & $\begin{array}{r}-21.81{ }^{*} \\
(-2.32)\end{array}$ \\
\hline $\begin{array}{l}\text { Inflation } \\
\text { d. Distance }\end{array}$ & $\begin{array}{r}5.23 \\
(0.43)\end{array}$ & $\begin{array}{r}5.28 \\
(0.44)\end{array}$ & $\begin{array}{r}5.35 \\
(0.66)\end{array}$ & & & \\
\hline Geographic & -2.67 & -2.65 & -2.69 & -2.57 & -2.51 & 1.00 \\
\hline distance & $(-1.31)$ & $(-1.31)$ & $(-1.32)$ & $(-1.28)$ & $(-1.35)$ & (0.48) \\
\hline Cultural distance & $\begin{array}{r}-272.75^{*} \\
(-4.20)\end{array}$ & $\begin{array}{r}-273.67^{*} \\
(-4.24)\end{array}$ & $\begin{array}{r}-277.77^{*} \\
(-4.28)\end{array}$ & $\begin{array}{r}-268.46 \\
(-4.30)\end{array}$ & $\begin{array}{r}-195.29 \\
(-3.47)\end{array}$ & $\begin{array}{r}-187.43 \cdots \\
(-2.82)\end{array}$ \\
\hline e. Equilibrium & & & & & & \\
\hline Cost of lending & $\begin{array}{r}-1.09 \\
(-0.25)\end{array}$ & $\begin{array}{r}-1.09 \\
(-0.25)\end{array}$ & $\begin{array}{r}-1.03 \\
(-0.24)\end{array}$ & & $\begin{array}{r}-0.17 \\
(-0.68)\end{array}$ & \\
\hline Rate of return & $\begin{array}{r}-2.82 \\
(-0.75)\end{array}$ & $\begin{array}{r}-2.86 \\
(-0.76)\end{array}$ & $\begin{array}{r}-3.03 \\
(-0.80)\end{array}$ & $\begin{array}{l}-0.83^{\circ} \\
(-1.96)\end{array}$ & & $\begin{array}{r}-0.19 \\
(-0.47)\end{array}$ \\
\hline Exchange rate & $\begin{array}{l}11.63 \\
(0.10)\end{array}$ & $\begin{array}{l}11.46 \\
(0.10)\end{array}$ & $\begin{array}{r}9.13 \\
(0.08)\end{array}$ & $\begin{array}{r}-3.63 \\
(-0.12)\end{array}$ & $\begin{array}{r}2.25 \\
(0.09)\end{array}$ & $\begin{array}{r}0.32 \\
(0.01)\end{array}$ \\
\hline Wage & $\begin{array}{r}55.48 \cdots \\
(2.77)\end{array}$ & $\begin{array}{r}55.62 \cdots \\
(2.78)\end{array}$ & $\begin{array}{r}55.04 \cdots \\
(2.74)\end{array}$ & $\begin{array}{r}54.70 \cdots \\
(2.76)\end{array}$ & $\begin{array}{r}41.80 \\
(2.38)\end{array}$ & $\begin{array}{r}72.95 \cdots \\
(3.25)\end{array}$ \\
\hline Durbin-Watson & 1.69 & 1.69 & 1.70 & 1.68 & 1.72 & 1.69 \\
\hline Adjusted $\mathrm{R}^{2}$ & 0.317 & 0.320 & 0.315 & 0.323 & 0.291 & 0.191 \\
\hline Anova (F-test) & $9.602 \cdots$ & $10.445^{\cdots}$ & $10.248^{\cdots *}$ & $12.554^{\cdots *}$ & $12.981^{\cdots}$ & $7.333^{\cdots}$ \\
\hline Years & 13 & 13 & 13 & 13 & 13 & 13 \\
\hline $\mathrm{N}$ & 241 & 241 & 241 & 242 & 292 & 242 \\
\hline
\end{tabular}

" $=$ significant at the 0.10 level ${ }^{*}=$ significant at the 0.05 level ${ }^{\cdots}=$ significant at the 0.01 level Note: T-statistics in parentheses 
Furthermore, the data in Table 3A.2 also show that the financial variables are highly correlated (correlation $>0.89$ ) resulting in high vif-values (the difference in cost of borrowing (vif $=494.7)$, the rate of return (vif $=224.2)$, and inflation (vif $=1027.9)$ in specification A, Table 3.5). We therefore tested individual models including only one or a combination of these variables. The only variable that is significant when tested independently of the others is the difference in rate of return between the Netherlands and the home country. The results of this specification are given in the table under D.

The tests for relative cost of borrowing and for the difference in inflation give comparable results. Only the first is therefore presented in specification E. We only report for imports in the Netherlands from the home country because their influence on FDI inflow was largest.

Furthermore, the data also show a strong correlation between GDP and population (0.741) resulting in unacceptable vif-values for both variables in specifications A-D, but not for $\mathrm{E}^{18}$. Combining the variables can give a solution to this collinearity problem. We therefore tested GDP per capita (a combination of the two) as a market-related determinant of FDI flows in specification F.

The overall model specification is robust. The F-statistics are significant at the 1 percent level (p-value $<0.01$ ) indicating at least a 99 percent probability that the coefficients of the explanatory variables are not zero. The Durbin-Watson (DW) statistics are of a magnitude that manifests an absence of positive first-order serial autocorrelation at the 1 percent level. The adjusted R-square indicates the explanatory power of the model. For E and $\mathrm{F}$, the model specifications that have the most reliable fit because we have excluded all collinear variables there, the explanatory power is 32 and 19 percent. Specification E clearly has considerably higher explanatory power.

The results from specifications $\mathrm{E}$ and $\mathrm{F}$ indicate that the most important factors determining the inflow of FDI into the Netherlands include trade relations, the cultural distance between the Netherlands and the home country, home country population size, differences in the wage level, political risk, and home country GDP. We therefore find support for all five groups of variables identified by the conceptual model presented in Figure 3.1.

Table 3.6 gives an overview of the hypotheses and the test results. Trade relations (both imports and exports) between the Netherlands and the home country of the investors turn out to be a significant factor $(\mathrm{p}<0.01)$, positively influencing inward FDI flows to the Netherlands for specifications B-F. This result strongly confirms hypothesis one. The greater the trade flows between the home economy and the Netherlands, the larger the investment flows to the Netherlands. FDI can complement already existing trade and familiarity with the host market, through trading experience, facilitates investments as well.

${ }^{18}$ Vif-factors range between $14.48-17.30$ for GDP and between 14.72 and 15.78 for population. 
Table 3.6 Hypotheses tests

\begin{tabular}{|c|c|c|}
\hline \multicolumn{2}{|r|}{ Hypothesis } & \multirow{2}{*}{$\begin{array}{l}\text { Confirmed? } \\
\text { Yes }\end{array}$} \\
\hline & $\begin{array}{l}\text { The larger the amount of existing trade between the Netherlands and a particular } \\
\text { home economy, the greater the FDI flow from that country into the Netherlands }\end{array}$ & \\
\hline 2 & $\begin{array}{l}\text { The larger the home country GDP, the greater the FDI flow from that country into } \\
\text { the Netherlands }\end{array}$ & Yes \\
\hline 3 & $\begin{array}{l}\text { The larger the home country population, the smaller the FDI flow from that } \\
\text { country into the Netherlands }\end{array}$ & Yes \\
\hline 4 & $\begin{array}{l}\text { The larger the positive difference in GDP growth between the Netherlands and } \\
\text { the home country, the greater the FDI flow from that country into the Netherlands }\end{array}$ & No \\
\hline 5 & $\begin{array}{l}\text { The greater the political risk of the home country compared to the Netherlands, } \\
\text { the greater the FDI flow from that country into the Netherlands }\end{array}$ & $\mathrm{No}^{\circ}$ \\
\hline 6 & $\begin{array}{l}\text { The larger the inflation rate in the home country compared to the Netherlands, the } \\
\text { greater the FDI flow from that country into the Netherlands }\end{array}$ & No \\
\hline 7 & $\begin{array}{l}\text { The greater the cultural distance between the home country and the Netherlands, } \\
\text { the smaller the FDI flow from that country into the Netherlands }\end{array}$ & Yes \\
\hline 8 & $\begin{array}{l}\text { The greater the geographical distance between the home country and the } \\
\text { Netherlands, the smaller the FDI flow from that country into the Netherlands }\end{array}$ & No \\
\hline 9 & $\begin{array}{l}\text { The lower the cost of borrowing in the home country versus that in the } \\
\text { Netherlands, the greater the FDI flow from that country into the Netherlands }\end{array}$ & No \\
\hline & $\begin{array}{l}\text { The higher the wage rate in the Netherlands compared to the wage rate in the } \\
\text { home country, the lower the FDI flow from that country into the Netherlands }\end{array}$ & No ${ }^{\circ}$ \\
\hline & $\begin{array}{l}\text { The lower the expected rate of return in the home country compared to the } \\
\text { expected rate of return in the Netherlands, the greater the FDI flow from that } \\
\text { country into the Netherlands }\end{array}$ & No \\
\hline & $\begin{array}{l}\text { The greater the revaluation of the home country currency against the Dutch } \\
\text { guilder, the greater the FDI flow from that country into the Netherlands }\end{array}$ & No \\
\hline
\end{tabular}

For these hypotheses we find significant results opposing the suggested relationship

We also find strong support for the market-related variables. The estimated influence of home country's previous period GDP is positive, highly significant as hypothesised $(\mathrm{p}<0.01)$ for all specifications. In line with hypothesis two, large GDP in the home economy in the previous period does encourage firms to explore other markets. However, a large home country population exerts a significant $(\mathrm{p}<0.01)$ negative influence on FDI flows between the home country and the Netherlands, confirming hypothesis 3 . We can therefore conclude that although the presence of many firms in the home market encourages FDI flows, the actual large home country consumer base acts as a deterrent for FDI flows. Combining these variables to reduce collinearity among them (specification $\mathrm{F}$ ) result in a highly significant $(\mathrm{p}<0.01)$ and positive influence of home country GDP per capita on FDI inflows. This result further supports hypothesis two. The difference between the growth of GDP in the Netherlands and the home country contradicts our expectations, but the results are insignificant in all specifications and therefore have to be interpreted carefully. We find no evidence to confirm hypothesis 4 . We cannot support hypotheses 5 and 6 regarding the environmental variables based on our analyses in this study. Inflation-differences have no significant effect on FDI in any of these six model specifications. This result is not surprising considering the relative 
stability that has characterised the economic and political climate in the Netherlands over the last decade. Regarding the difference in political risk between the Netherlands and the home country, we find significant evidence (at the 10 percent level in specifications $\mathrm{B}, \mathrm{C}$, D, and F) that suggests the opposite from hypothesis five. Whenever the Netherlands is more stable than the home country of the investor, investments will be deterred. However, a look at the raw data reveals that some of the largest foreign investing countries, such as Germany, the United States, Switzerland, and Japan were characterised by even higher scores on the country credit rating than the Netherlands for the period considered. This explains our surprising result.

We find strong support for the cultural distance variable. Cultural distance between the Netherlands and the home country has a large and significant $(\mathrm{p}<0.01)$ negative effect in all specifications. This result is in line with our seventh hypothesis. If the cultural distance is large, it is more difficult to manage affiliates in the Netherlands and therefore relatively few investments will take place. The influence of geographic distance is also negative (except for specification F), but not significant in any specification. We therefore find no support for hypothesis eight. This result may be strongly influenced by the relatively large and dominant share of US investments in overall investments in the Netherlands. These investments occur even though the geographical distance between the two countries is large ${ }^{19}$.

The market-disequilibrium factors show mixed results. Contrary to our expectation as formulated in hypothesis 9 that the high cost of borrowing in the Netherlands would give foreign firms a superior position over Dutch investors and would therefore positively influence FDINL, we find that the effect is insignificant and negative. The difference in wage levels exerts an unexpected positive, significant influence on FDI flows $(\mathrm{p}<0.01$ for all specifications), contradicting hypothesis 10 . Contrary to our expectations we find that a relatively high wage level in the Netherlands attracts foreign investment. The effect of the rate of return is only significant in specification $\mathrm{D}(\mathrm{p}<0.10)$, but does not have the expected sign, giving no support for hypothesis 11 . The insignificant coefficient of exchange rate revaluations offers no support for hypothesis 12 .

\subsection{Discussion}

Our main objective in this chapter was to test the influence of macro-economic variables on the decision to invest in one particular host economy, the Netherlands. To this end, we explored the relationship of five groups of variables (trade, market, costs, distance, and environment) on investment flows from the home country to the Netherlands. The results of this study are important for several reasons. First of all, they strongly support the

\footnotetext{
${ }^{19}$ We have reestimated the model excluding the US. The results are comparable to the results presented in specifications $\mathrm{E}$ and $\mathrm{F}$ of Table 3.5. The geographical distance variable has the same sign and remains insignificant. For total FDI inflow into the Netherlands, geographical distance therefore does not turn out to be an explanatory variable.
} 
importance of trade relationships between the home and the host country. The results confirm earlier empirical studies by Ferris et al. (1994), Grosse and Trevino (1996), and Liu et al. (1997). The analyses support the notion that FDI is used to preserve markets that were previously established by exports. This is in line with the Uppsala internationalisation theories of Johanson and Vahlne (1977), Luostarinen (1979), and Welch and Luostarinen (1988) that suggest an evolutionary path that firms follow when they expand to foreign markets. After initial exports via an agent, firms will open a sales subsidiary that eventually can develop into a production unit. The results offer strong support for the importance of business experience in the host market. When firms, through exports, learn about and get acquainted with a host market, they will be more inclined to extend their activities with FDI that involves a greater commitment to the host market (Johanson and Vahlne 1977, Narula and Wakelin 2001). These results therefore suggest that any country that wants to attract FDI should invest in building strong trade relations. Over time these trade relationships can be transformed to actual investments if the business results indicate the feasibility of an independent local establishment.

Secondly, we find strong and significant support for the negative influence of cultural distance on FDI activity in a host economy. These results are in line with previous empirical studies by, for instance, Grosse and Trevino (1996) and Liu et al. (1997). Particularly the cultural distances of the home country to the Netherlands exert a negative influence on the investment flows to this host economy. Countries culturally dissimilar to the Netherlands tended to have smaller FDI flows into the Netherlands. Several studies have suggested that the cultural distance between the home and host country strongly influences the choice for the mode of entry (Kogut and Singh 1988, Erramilli and Roa 1993, Barkema et al. 1996, Bell 1996, Brouthers and Brouthers 2001). When the cultural difference between the home and the host is large, MNEs are unfamiliar with the local norms, values, language, customs, laws and regulations, behaviour, and traditions (Hofstede 1980). They will therefore have difficulties in operating in the host market. They may, for example, unintentionally offend local governments or clients by acting in a way that is different from what is expected (Bell 1996). Considerable cultural differences therefore result in entry modes with an intermediate commitment such as joint ventures (Gatignon and Anderson 1988, Kogut and Singh 1988, Erramilli and Roa 1993, Bell 1996, Brouthers and Brouthers 2001). If the differences are very large, firms may even consider low commitment strategies such as licensing (Arora and Fosfuri 2000). Of course, a lower commitment results in fewer positive influences and spillovers of MNE activity on the host economy. The results of this study therefore suggest that host country governments that try to attract FDI to their country should focus their attention on firms in countries that are culturally similar. These firms are most likely to consider the host country as a location for foreign investment activities ${ }^{20}$. Firms located in countries very

${ }^{20}$ Kasper et al. (1999) draw attention to the fact that cultural closeness is frequently related to a similarity in language. 
dissimilar from the host will have much more difficulties in doing business there and therefore need greater (financial) incentives to come.

Thirdly, contrary to our expectation, our study shows that the higher labour costs in the Netherlands do not act as a deterrent to international investors. Surprisingly, even though wages are relatively high, the Netherlands still attracts considerable new investments. Mainstream FDI theory expects that low wage are generally attracting foreign investors that want to take advantage of cheap resources (see for instance Liu et al. 1997), but in case of the Netherlands this effect is exactly the opposite. This result is more in line with the empirical findings of Zhao and Zhu (2000) for regions in China. This result is much less surprising if one considers the high wages in the Netherlands to be an indicator of high productivity and high quality labour. They could actually be an incentive rather than a deterrent of FDI in those cases where foreign firms search for highly-skilled personnel (Papanastassiou and Pearce 1994). Foreign firms may then choose the Netherlands for their new affiliates to improve efficiency in the production process and to take advantage of the well-educated workforce. Furthermore, Lucas (1993) emphasises that high labour costs in a particular host country may also encourage the substitution of capital for labour, thus increasing FDI flow. We expect that both explanations are valid for the Dutch situation and help in explaining the obtained results.

Fourthly, the results of this study confirm the importance of market related variables as determinants of foreign investment flows. We find strong support for the importance of a large home country size confirming earlier studies by Grosse and Trevino (1996) and Liu et al. (1997). A large economy usually has more large firms that could pursue international expansion. However, we also find that a large home country population exerts a significant negative influence on Dutch inward FDI flows. If a home market has many local customers, local firms can achieve economies of scale and scope in their home country and therefore are less inclined to explore more risky foreign markets. At first glance these results may seem conflicting, particularly given the high correlation between GDP and population (see Table 3A.2). However, our test of GDP per capita in specification $\mathrm{F}$ (Table 3.5) clearly indicates the strong positive influence of home market size on FDI inflows in the Netherlands. A local customer base of wealthy consumers can result in large sales and perhaps profits that alleviate the financial burden of more/new (foreign) investments. We therefore conclude that wealthy, large countries are a better target for host country FDI policies than poorer, smaller countries.

Finally, our results give no support for the notion that foreign investors take advantage of their home country's relatively strong currency when looking for acquisition opportunities in host economies. This result therefore contradicts earlier studies by Kogut and Chang (1996) for Japanese investments in the US and by Zander and Zander (1996) for all inflows in Sweden. This result is not surprising, however, considering that the years analysed in this study were characterised by a relatively strong guilder. Furthermore, with most of the important investor home countries, the Netherlands had exchange rate pegs within the EU agreements. Only minor movements of the exchange 
rates where allowed within the "snake" that the EU members had agreed upon. The relative stability in exchange rates as a result of this peg explains the lack in explanatory value of this variable for the Netherlands. For investments between the European Union countries, this factor will no longer play any role when the introduction of the Euro is completed on January $1^{\text {st }}, 2002$. The small margin of flexibility in the exchange rates between EU currencies will then disappear completely. Furthermore, movements in the Euro value against any other foreign currency will equally affect the attractiveness of all participating Euro-countries. A devaluation of the Euro against, for example, the dollar will then make investments in all participating EU countries more attractive for American investors.

\subsection{Conclusion}

Even though the Netherlands is generally considered a small economy, it has attracted a remarkable amount of inward foreign direct investment. This study develops a comprehensive exploratory model of the macro-economic factors that contribute to the explanation of FDI in the Netherlands by home country. The analysis presents evidence of the factors contributing to the inflow of FDI in the Netherlands between 1987 and 1999 based on pooled cross-section and time series data for 28 home countries. The investments considered accounted for about 90 percent of total investments in the Netherlands in this period and the results are therefore broadly generalisable.

Evidence from this period shows that when considering specific home countries, one of the main significant positive influences is home country's trade with the host country (including both exports to and imports from the Netherlands). Other positive determinants include the labour costs differential (signalling high labour quality), and home country market size. The cultural distance between the Netherlands and the home economy acts as the most important deterrent to FDI inflows.

The analyses conducted in this chapter consider the macro-economic determinants of the total inward FDI flows in the Netherlands. We do not distinguish the determinants by sector nor by region in the Netherlands due to the unavailability of data from DNB. However, once the choice for a particular host country has been made, firms will start investigating the locations within the host country (such as provinces and cities) as potential sites for their establishment abroad. It would therefore be useful to take a closer look at the determinants of FDI at a regional level. Which factors help explain the choice for a particular region in the Netherlands? This analysis is conducted in Chapter four.

The macro-economic model developed in the present chapter explains up to 32 percent of the variation in inward FDI in the Netherlands. A large share of the variation therefore remains unexplained and must be attributed to other key factors ${ }^{21}$. The remaining variation is most likely due to influences that are company- or industry-specific. To

${ }^{21}$ Inclusion of these other variables might also change the surprising results obtained in the present analyses. 
capture their effects, we expand our analysis with a questionnaire study of foreign firms in the Dutch electronics industry. The results of the questionnaire study on the locational determinants of FDI in the Netherlands are presented later in this study in Chapter five. 


\section{Appendix 3.1 The data}

Table 3A.1 Overview of the variables used in the empirical study

\begin{tabular}{|c|c|c|c|c|}
\hline Variable & Code & $\begin{array}{l}\text { Expected } \\
\text { Influence }\end{array}$ & Measurement & Source \\
\hline $\begin{array}{l}\text { Existing bilateral } \\
\text { trade }\end{array}$ & $\begin{array}{l}\text { Import/ } \\
\text { Export }\end{array}$ & + & $\begin{array}{l}\text { Exports from the home country } \\
\text { into the Netherlands (IMP) and } \\
\text { imports into the home country } \\
\text { from the Netherlands (EXP), } \\
\text { annually (billions of US\$) }\end{array}$ & $\begin{array}{l}\text { IMF ( } 2000 \mathrm{a}) \text { Direction } \\
\text { of Trade Statistics }\end{array}$ \\
\hline $\begin{array}{l}\text { Size of home } \\
\text { country market }\end{array}$ & $\begin{array}{l}\text { Gross } \\
\text { Domestic } \\
\text { Product } \\
\text { (GDP) }\end{array}$ & + & $\begin{array}{l}\text { Home country GDP, annually } \\
\text { (billions of US\$) }\end{array}$ & $\begin{array}{l}\text { World Bank (various } \\
\text { dates) World } \\
\text { Development Report; } \\
\text { World Bank (various } \\
\text { dates) World Tables } \\
\end{array}$ \\
\hline $\begin{array}{l}\text { GDP growth } \\
\text { difference } \\
\text { between host and } \\
\text { home }\end{array}$ & Growth & + & $\begin{array}{l}\text { Annual difference between } \\
\text { Dutch GDP annual growth in } \\
\text { percentages and home economy } \\
\text { GDP growth }\end{array}$ & $\begin{array}{l}\text { United Nations (vd) } \\
\text { Statistical Yearbook }\end{array}$ \\
\hline $\begin{array}{l}\text { Home country } \\
\text { population }\end{array}$ & POP & - & $\begin{array}{l}\text { Population in the home country, } \\
\text { annually }\end{array}$ & $\begin{array}{l}\text { World Bank (various } \\
\text { issues) }\end{array}$ \\
\hline Political risk & Risk & + & $\begin{array}{l}\text { Country risk, defined as the } \\
\text { difference between the country } \\
\text { credit ratings for the home } \\
\text { country and the credit rating for } \\
\text { the Netherlands, annually }\end{array}$ & $\begin{array}{l}\text { Country credit ratings in } \\
\text { Institutional Investor } \\
\text { (various issues) }\end{array}$ \\
\hline $\begin{array}{l}\text { Geographic } \\
\text { distance from the } \\
\text { Netherlands }\end{array}$ & Distance & - & $\begin{array}{l}\text { Number of km from the home } \\
\text { country capital to Amsterdam } \\
\text { (in } 100 \mathrm{~km} \text { ) }\end{array}$ & $\begin{array}{l}\text { The distance calculation } \\
\text { is done using } \\
\text { http://www.indo.com/cgi } \\
\text {-bin/dist }\end{array}$ \\
\hline $\begin{array}{l}\text { Cultural distance } \\
\text { from the } \\
\text { Netherlands }\end{array}$ & Culture & - & $\begin{array}{l}\text { Total cultural difference } \\
\text { between the Netherlands and } \\
\text { the home country, defined by a } \\
\text { composite index based on the } \\
\text { deviation of each four Hofstede } \\
\text { cultural dimensions of each } \\
\text { country from the Dutch } \\
\text { ranking, as done by Kogut and } \\
\text { Singh (1988) }\end{array}$ & $\begin{array}{l}\text { Hofstede (1980), } \\
\text { Hofstede (1997), Kogut } \\
\text { and Singh (1988) }\end{array}$ \\
\hline
\end{tabular}




\begin{tabular}{|c|c|c|c|c|}
\hline $\begin{array}{l}\text { Relative cost of } \\
\text { borrowing }\end{array}$ & Lending & + & $\begin{array}{l}\text { Borrowing costs, defined as the } \\
\text { difference between the Dutch } \\
\text { real lending interest rate and the } \\
\text { home country's real lending } \\
\text { interest rate, annually }\end{array}$ & $\begin{array}{l}\text { IMF (2000b) } \\
\text { International Financial } \\
\text { Statistics Yearbook }\end{array}$ \\
\hline $\begin{array}{l}\text { Relative rate of } \\
\text { return }\end{array}$ & Return & + & $\begin{array}{l}\text { Difference between the Dutch } \\
\text { average stock market share } \\
\text { price change at year end and the } \\
\text { home country stock market } \\
\text { average share price change at } \\
\text { year end" }\end{array}$ & $\begin{array}{l}\text { IMF }(2000 \mathrm{~b}) \\
\text { International Financial } \\
\text { Statistics Yearbook }\end{array}$ \\
\hline Exchange rate & Exchange & + & $\begin{array}{l}\text { Change in relative real } \\
\text { exchange rate, defined as the } \\
\text { ratio of the real guilder/US\$ } \\
\text { exchange rate to the real home } \\
\text { country/ US \$ exchange rate, } \\
\text { annually }\end{array}$ & $\begin{array}{l}\text { IMF (2000b) } \\
\text { International Financial } \\
\text { Statistics Yearbook }\end{array}$ \\
\hline Wage rate & Wage & - & $\begin{array}{l}\text { The difference in real hourly } \\
\text { compensation costs in US } \\
\text { dollars for production workers } \\
\text { in manufacturing between the } \\
\text { Netherlands and the source } \\
\text { country, annually }\end{array}$ & $\begin{array}{l}\text { US Department of } \\
\text { Labor, Bureau of Labor } \\
\text { Statistics }\end{array}$ \\
\hline Relative Inflation & Inflation & - & $\begin{array}{l}\text { Relative inflation rate, defined } \\
\text { as the ratio of Dutch inflation to } \\
\text { the home country's inflation } \\
\text { rate, annually }\end{array}$ & $\begin{array}{l}\text { IMF (various issues) } \\
\text { World Economic } \\
\text { Outlook }\end{array}$ \\
\hline
\end{tabular}

For Austria, Turkey and Brazil we used the relative money market rate, for Saudi Arabia the relative deposit rate because lending rates were not available for these countries

" Not available for Greece, Turkey, Malaysia, Indonesia, Singapore 
Table 3A.2 Correlation matrix

\begin{tabular}{|c|c|c|c|c|c|c|c|c|c|c|c|c|c|c|c|}
\hline & 胥 & क & 点 & $\bar{E}$ & $\bar{E}$ & $\frac{\sqrt{2}}{\alpha}$ & $\frac{\sqrt[6]{2}}{2}$ & $\frac{5}{0}$ & $\overline{\frac{1}{5}}$ & $\overline{0}$ & $\frac{6}{3}$ & 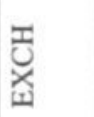 & 至 & $\sqrt[1]{x}$ & 点 \\
\hline FDINL & 416.22 & 1249.20 & & & & & & & & & & & & & \\
\hline $\begin{array}{l}\text { NL Import } \\
\text { (IMPT1) }\end{array}$ & 3.92 & 6.25 & .417 & & & & & & & & & & & & \\
\hline $\begin{array}{l}\text { NL Export } \\
\text { (EXPT1) }\end{array}$ & 4.36 & 8.09 & .333 & .956 & & & & & & & & & & & \\
\hline $\begin{array}{l}\text { Country risk } \\
\text { (RISK) }\end{array}$ & 16.36 & 16.78 & -.239 & -.428 & -.385 & & & & & & & & & & \\
\hline $\begin{array}{l}\text { Distance } \\
\text { (DIST) }\end{array}$ & 42.49 & 44.51 & -.108 & -.314 & -.382 & .288 & & & & & & & & & \\
\hline $\begin{array}{l}\text { Home market size } \\
\text { (GDPT1) }\end{array}$ & 647.02 & 1302.47 & .449 & $\begin{array}{r}.438 \\
. .\end{array}$ & .255 & -.367 & .109 & & & & & & & & \\
\hline $\begin{array}{l}\text { GDP growth } \\
\text { (GRT1) }\end{array}$ & -0.50 & 3.35 & .067 & .152 & .157 & -.078 & -.219 & .128 & & & & & & & \\
\hline $\begin{array}{l}\text { Home population } \\
\text { (POPT1) }\end{array}$ & 43.64 & 61.77 & $\begin{array}{r}.306 \\
. .\end{array}$ & .263 & .123 & .082 & .317 & .741 & .049 & & & & & & \\
\hline $\begin{array}{l}\text { Cultural distance } \\
\text { (DIST) }\end{array}$ & 2.36 & 1.29 & -.083 & -.066 & -.101 & .095 & $\begin{array}{r}.394 \\
.\end{array}$ & .150 & -.166 & .170 & & & & & \\
\hline $\begin{array}{l}\text { Exchange rate } \\
(\mathrm{EXCH})\end{array}$ & 0.39 & 5.77 & -.022 & -.027 & -.003 & -.164 & -.076 & -.001 & -.069 & .127 & -.004 & & & & \\
\hline $\begin{array}{l}\text { Lending rate } \\
\text { (LEND) }\end{array}$ & -99.06 & 945.94 & .035 & .049 & .053 & -.264 & -.114 & .025 & -.080 & -.170 & .003 & -.379 & & & \\
\hline $\begin{array}{l}\text { Rate of return } \\
\text { (RET) }\end{array}$ & -23.60 & 273.25 & .038 & .061 & .061 & -.321 & -.127 & .035 & -.003 & -.171 & -.008 & -.710 & .961 & & \\
\hline $\begin{array}{l}\text { Inflation } \\
\text { (INF) }\end{array}$ & -33.38 & 229.55 & .047 & .068 & .072 & -.365 & -.136 & .035 & -.060 & -.226 & .002 & -.463 & $\begin{array}{r}.885 \\
*\end{array}$ & $\begin{array}{r}981 \\
. .\end{array}$ & \\
\hline $\begin{array}{l}\text { Wage level } \\
\text { (WAGE) }\end{array}$ & 5.26 & 6.90 & -.170 & $\begin{array}{r}-.433 \\
.\end{array}$ & $\begin{array}{r}-.430 \\
.\end{array}$ & $\begin{array}{r}.639 \\
. .\end{array}$ & .509 & -.183 & -.405 & .027 & .361 & .082 & -.175 & $\begin{array}{r}-.230 \\
. .\end{array}$ & -.173 \\
\hline
\end{tabular}

${ }^{*}$ correlation is significant at the 0.01 level (2-tailed), ${ }^{*}$ correlation is significant at the 0.05 level (2-tailed), SD = Standard Deviation 


\section{AGGLOMERATION IN DUTCH INWARD FOREIGN INVESTMENTS}

\subsection{Introduction}

Business location is a topic that has attracted a lot of scientific attention over the years. With the rapid increase in foreign direct investment (FDI) activity since the 1980s, researchers started focussing on the locational determinants of foreign establishments. Most studies investigate country-specific macro-economic factors such as market size, the presence of natural resources, infrastructure, and the skills-level and cost of labour (see Dunning (1993) for a full list of factors). Many of these studies analyse aggregated data and sometimes compare the choices between two or more countries or the changes in attractiveness of a particular country over time (Agarwal 1980, Martin 1991, Mody and Srinivasan 1998, Schneider and Frey 1985, and Zhang 1994). We have conducted a similar analysis for the Netherlands in Chapter three of this study. It appeared that inward FDI flows to the Netherlands are positively influenced by the home country's trade with the Netherlands, the labour costs differential, and the home country market size. Investment inflows are deterred when the cultural difference between the Netherlands and the home country is large.

Lacking in most macro-economic studies is an analysis of the determinants of the choice for a particular region in the selected host economy. Only a few studies have explored the relationship between the establishment pattern of firms and the locational characteristics of the region. Some of these studies concentrate on local establishments only (Carlton 1983, Bartik 1985) while others take both local and foreign or only foreign establishments into account (such as Head et al. 1995, Shaver 1998, Woodward 1992, Wu and Strange 2000). Understanding the determinants of location decisions is important for local and regional governments and policy makers that want to encourage economic development in particular areas and seek to attract FDI to the region ${ }^{1}$.

So far the studies analysing the regional determinants of location choice focus on relatively large countries such as the US and China where distinct regions exist that differ

\footnotetext{
${ }^{1}$ Knowledge of the factors influencing a firm's location choice helps policy makers to design policies that enhance the attractiveness of a region for new investment (Carlton 1983). In the Netherlands, regional development companies such as LIOF, OOM, and BOM focus on strengthening the province's economic base by targeting projects and opportunities that will result in long term economic prosperity in the region. As discussed in Chapter one, foreign firms can contribute to the economic well-being of a region. It is therefore important to understand the factors that explain the attractiveness of a region to foreign firms.
} 
significantly in economic development and policies. However, the main objective for this chapter is to determine which factors influenced the foreign firm's choice for a particular region in a smaller host economy: the Netherlands.

Chapter two has shown that more than 7000 foreign firms have establishments in the Netherlands. They have made the choice for the Netherlands based on the overall characteristics of the country. In this chapter, we determine which factors explain their choice for a particular region within the Netherlands ${ }^{2}$. We want to examine if agglomeration patterns can be detected in inward FDI in the Netherlands, i.e. whether firms tend to locate their affiliates in geographically well-defined areas that for instance are specialised in similar activities. Furthermore, we would like to establish whether differences in regional location characteristics offer an explanation for the establishment pattern of foreign affiliates. The DutchInvest database (covering all foreign establishments in the Netherlands) offers a unique opportunity to study the location decision of these foreign firms.

In Section two, we first analyse the overall establishment pattern of inward FDI in the Netherlands, considering the (dis-)-similarity in location choice of Dutch and foreign establishments. Section three then discusses the different theoretical and empirical contributions to locational determinants of FDI and offers a conceptual model. Hypotheses based on this model are formulated in Section four. A description of the model used in the empirical analyses is given in Section five. We model the location choice within an adaptation of McFadden's (1974) discrete choice model. The data are discussed in Section six followed by a presentation of the results of the empirical model estimations in Section seven. A discussion of the results is given in Section eight. Section nine presents the conclusions.

\subsection{Foreign establishments in the Netherlands}

The DutchInvest-database, discussed in Chapter two and in Appendix Al at the end of this study, provides detailed information on the exact choice of location of each of the over 7000 affiliates' in the Netherlands. This locational pattern can be similar or dissimilar to that of local Dutch firms. Dissimilar location patterns might stem from differences between foreign and local firms with respect to their technologies or customer bases, the existence of agglomeration economies among foreign-owned establishments that motivate them to cluster together, or changes in location attractiveness over time that motivate foreign firms, who are often recent entrants, to value locations differently from incumbent local firms.

\footnotetext{
${ }^{2}$ We acknowledge the fact that regions in the Netherlands cannot be compared with states in the United States or provinces in the People's Republic of China given their considerably smaller size. The analyses conducted in this chapter aim at finding out whether it is possible to distinguish (groups of) variables that explain why foreign firms choose particular regions within the Netherlands for their Dutch establishment.
} 
On the other hand, similar location patterns may stem from the geographic concentration of production factors or demand that both foreign and local firms value similarly. Furthermore, industry agglomeration economies may exist, which are positive externalities arising from the geographic clustering of industry (Head et al. 1995, Schmutzler 1999). They may encourage both local and foreign firms in the same sector to cluster together resulting in similar locational choices.

In order to assess if the distributions of foreign-owned and Dutch-owned establishments are similar across regions, we employed a $\chi^{2}$ test on a $2 \times 12$ table, where the columns represent foreign-owned and Dutch establishment counts, and the rows each present a region in the Netherlands. The data on foreign establishments are taken from the DutchInvest database (limiting the analysis to the 7059 establishments present at Jan. $1^{\text {st }}$ 1995). The total establishments are taken from the "Bedrijven in Nederland 1997" statistics, collected by the Dutch Central Bureau of Statistics (CBS) ${ }^{3}$. Dutch establishments are calculated by deducting the foreign establishments from the total establishments.

Table 4.1 presents the establishment counts ${ }^{4}$ of foreign firms operating in the Netherlands. The foreign establishments are also presented in Figure 4.1. At first glance, the establishment patterns of local and foreign firms differ for each region. Particularly the regions Groningen, Friesland, Drenthe (up in the north of the Netherlands), Overijssel and Gelderland (in the east), and Limburg (down in the south) attract a smaller share of total foreign firms than of local ones. However, there are also important similarities. Particularly the regions Noord Holland, Zuid Holland, and Utrecht (comprising the Randstad-area) attract more foreign firms than other regions. These regions and Noord Brabant are very popular among local firms as well.

The test statistic $\left(\chi_{11}^{2}=2158\right)$ rejects the null-hypothesis that the location distributions for Dutch-owned and foreign-owned establishments are identical at the 0,0001 level. Foreign and Dutch firms clearly differ in their location choice. It is therefore very interesting to determine which factors influence the foreign firm's choice for a particular location in the Netherlands.

We distinguish two levels of analysis. First of all, the Randstad-area (broadly encompassing the provinces Noord Holland, Zuid Holland and Utrecht, see Figure 4.1) versus the rest of the Netherlands. As discussed in Chapter two, the Randstad benefits

\footnotetext{
${ }^{3}$ Unfortunately, a complete overview of new establishments is not available for a more recent date. We therefore have to limit the analyses to establishment patterns up to 1995 and new entrants up to 1996 . The statistics in "Bedrijven in Nederland 1997" report the number and size of all establishments in the Netherlands in 1995, 1996, and 1997. However, statistics for each province and Corop region are only available for January $1^{\text {st }}, 1995$.

${ }^{4}$ We have counted each Dutch affiliate of a foreign firm as one establishment if it is registered as a private limited company (B.V.) or is reported as an independent company in the Dun and Bradstreet database (see Appendix A for a description of the DutchInvest database). We have only considered those Dutch establishments whose ultimate owner is a foreign firm and have not taken firms into account whose ultimate owner is a Dutch affiliate of a foreign firm.
} 
from its favourable location near the North Sea and good infrastructural provisions such as Schiphol airport and the Rotterdam harbours. Furthermore, large cities such as Amsterdam, Rotterdam, The Hague, and Utrecht are important business centres in this region. We therefore expect foreign firms to choose between the Randstad and the rest of the Netherlands. The second level of analysis is provincial. We want to look more closely at the attractiveness of each of the twelve individual provinces of the Netherlands. Although they are basically administrative entities, some distinctly stand out due to their own language (such as Friesland) or history (the newly developed land in Flevoland). We would like to determine whether characteristics of the provinces can explain their attractiveness to foreign affiliates.

Table 4.1 Dutch establishment patterns of local and foreign firms per region, 1995

\begin{tabular}{|l|r|r|r|r|}
\hline Region & Foreign & Share of all foreign (\%) & Local & Share of all local (\%) \\
\hline Groningen & 61 & 0,9 & 21754 & 3,3 \\
Friesland & 35 & 0,5 & 27065 & 4,1 \\
Drenthe & 47 & 0,7 & 19258 & 2,9 \\
Overijssel & 171 & 2,4 & 45639 & 7,0 \\
Gelderland & 535 & 7,6 & 81435 & 12,5 \\
Utrecht & 667 & 9,4 & 45228 & 6,9 \\
Noord Holland & 2286 & 32,4 & 110589 & 16,9 \\
Zuid Holland & 1775 & 25,1 & 129060 & 19,8 \\
Zeeland & 67 & 0,9 & 18163 & 2,8 \\
Noord Brabant & 1033 & 14,6 & 99387 & 15,2 \\
Limburg & 303 & 4,3 & 45502 & 7,0 \\
Flevoland & 79 & 1,1 & 10151 & 1,6 \\
\hline
\end{tabular}

$\left(\chi_{11}^{2}=2158, \mathrm{p}<0.0001\right)$

\subsection{A brief overview of studies on locational choice}

With the increasing importance of multinational enterprises (MNEs), many theoretical perspectives have been developed to explain modes, motives, and locational choice for international business activities. In this chapter, we again focus on the locational determinants of foreign investment decisions. However, instead of looking at macroeconomic factors that explain the attractiveness of a host country, like we did in Chapter three, we now concentrate on regional economic differences that might help explain the attractiveness of specific regional areas in the host economy. Several empirical studies examined the locational determinants of investments in particular regions (such as Bartik 1985, Carlton 1983, Cheng and Kwan 2000, Friedman et al. 1992, Head et al. 1995, Kittiprapas and McCann 1999, Shaver 1998, Woodward 1992, Wu and Strange 2000). These studies tested hypotheses on a large number of variables that influenced the choice for a particular (host) location. Table 4.2 gives an overview of the most important results of these studies. 


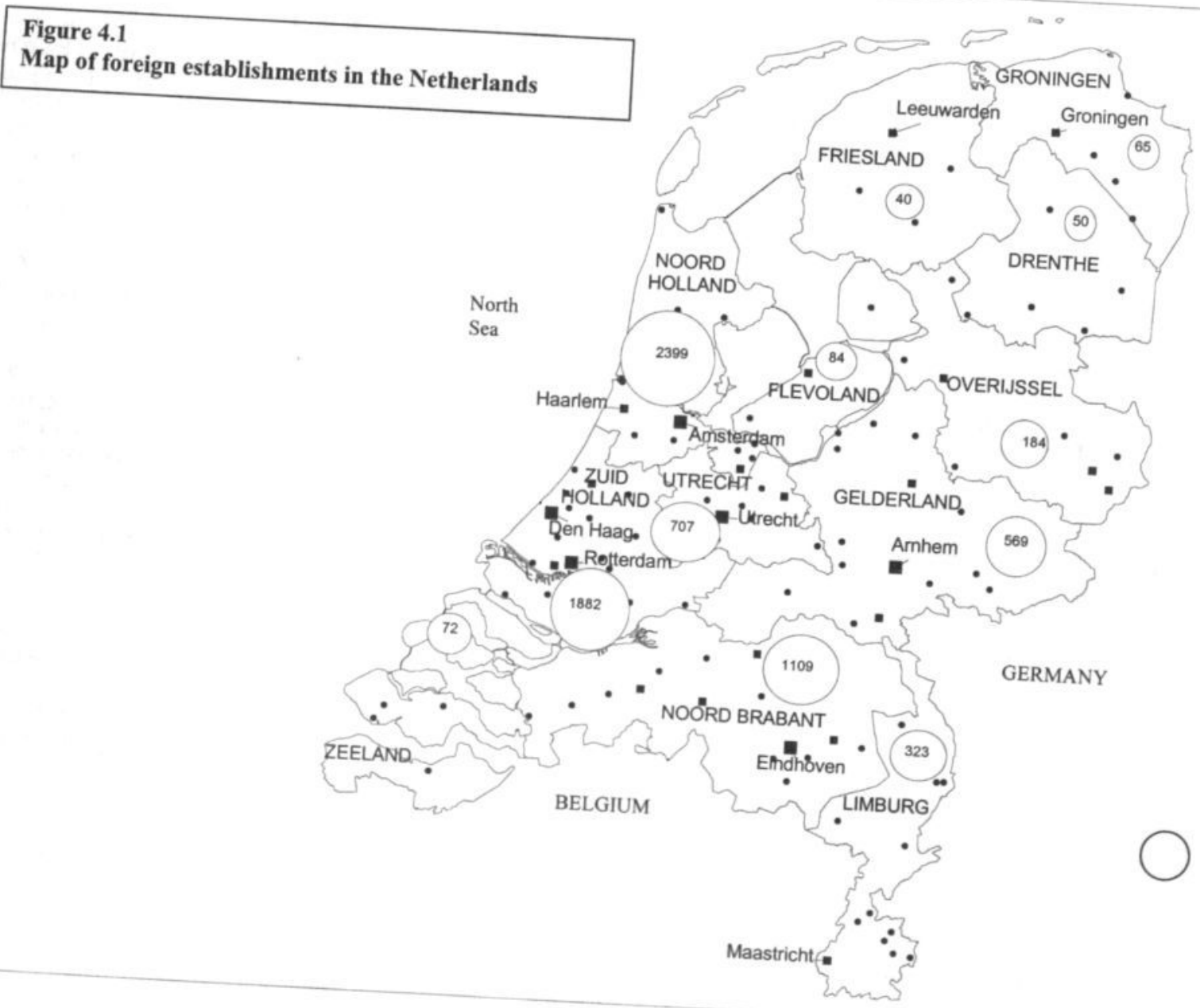

Number of foreign establishments in a particular region in the Netherlands 
Table 4.2 Overview of the finding of empirical studies on the determinants of location choice

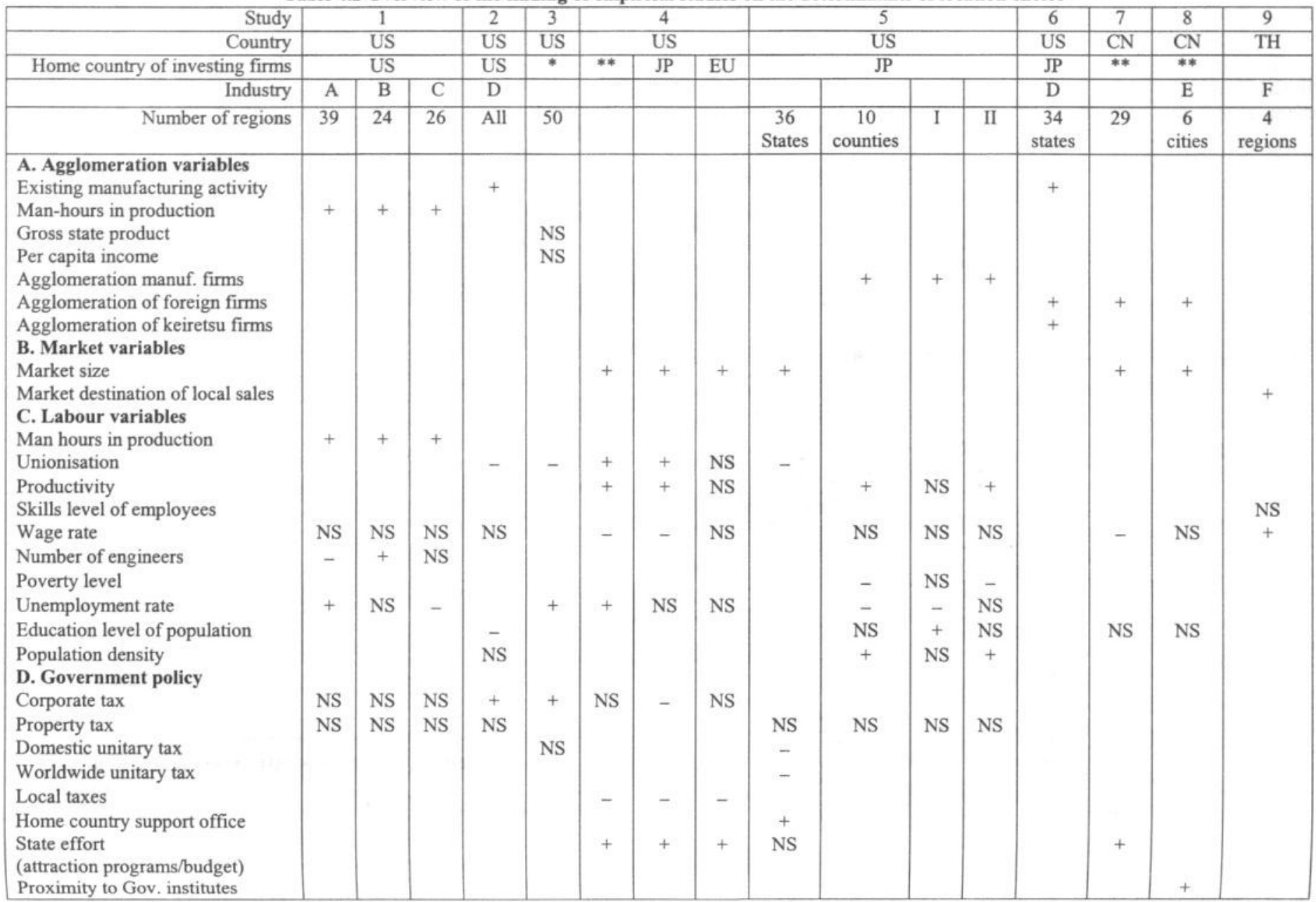


rgy costs)

Road miles

Interstate connection

F. Geographic variables

Land area

Geographic location

(coastal areas)

Number of observations

- Loglikelihood value (E3)

\section{Study}

$1=$ Carlton (1983)

$4=$ Friedman et al. (1992)

$7=$ Cheng and $\mathrm{Kwan}(2000)$

\begin{tabular}{|c|c|c|c|c|c|c|c|c|c|c|c|c|c|c|c|}
\hline 290 & 84 & 153 & $\begin{array}{l}\text { NS } \\
\text { NS }\end{array}$ & + & $\begin{array}{c}\text { NS } \\
+\end{array}$ & $\begin{array}{l}- \\
+\end{array}$ & $\begin{array}{l}- \\
+\end{array}$ & + & $\begin{array}{l}+ \\
+\end{array}$ & $\begin{array}{l}+ \\
+\end{array}$ & $\begin{array}{l}\text { NS } \\
+\end{array}$ & & $\begin{array}{l}+ \\
+\end{array}$ & & \\
\hline 290 & 84 & 153 & 1067 & 50 & 884 & 338 & 440 & 540 & 540 & 250 & 290 & 751 & & 138 & 115 \\
\hline 1.5 & 3.8 & 7.5 & & & 1.7 & 0.6 & 0.9 & 1.8 & 0.9 & 0.4 & 0.4 & 2.2 & & 0.2 & \\
\hline
\end{tabular}

\section{Country}

US $=$ United States

$\mathrm{TH}=$ Thailand

$2=$ Bartik (1985)

$5=$ Woodward (1992)

$8=$ Wu and Strange (2000)

$\mathrm{JP}=\mathrm{Japan}$

$\mathrm{EU}=$ European Union

$\mathrm{B}=$ Communication transmission equipment $\mathrm{E}=$ Insurance
$3=$ Shaver $(1998)$

$6=$ Head et al. (1995)

$9=$ Kittiprapas and McCann (1999)

$\mathrm{CN}=$ China

\section{Industry}
$\mathrm{A}=$ Plastic products
$\mathrm{D}=$ All manufacturing (SIC 20-39)

\section{Region}

$\mathrm{I}=$ Auto Alley

II = Non auto alley

\section{Home country of investment}

* All foreign

** Japan, West Germany, United Kingdom, Canada, Switzerland, France, Netherlands, other

\section{Notes}

NS $=$ No significant influence on location choice

$+=$ Increased probability of choice for a particular location
$-=$ Decreased probability of choice for a particular location

\section{$\mathrm{C}=$ Electronic components \\ $\mathrm{F}=$ Electronics}


Early studies on the determinants of a firm's location choice focused specifically on the choices made by local firms. Important examples include Carlton (1983) and Bartik (1985). Carlton (1983) estimates both the decision where to locate and how many employees to hire in three narrowly defined industries: fabricated plastic products $(n=290)$, communication equipment $(n=84)$, and electronic components $(n=153)$ in the United States. Using simple logit models, he finds that in all these three industries energy costs have a positive and significant effect on the choice of location ${ }^{5}$. Both wage level and taxes (property and corporate) have no significant influence on location choice. Furthermore, Carlton (1983) finds strong evidence that existing concentrations of employment (measured by man-hours in production) attract new establishments. Highly sophisticated industries (such as communication equipment) favour regions with available technical expertise (measured by the number of engineers in a region).

Bartik (1985) uses a conditional logit model to analyse new branch plant location decisions for 1067 US manufacturing firms in the United States. The empirical results suggest that high unionisation has a very strong negative effect on new business activity in a state. Investments are deterred when firms expect difficulties in hiring and firing employees. Furthermore, locations with low corporate taxes appear attractive for new manufacturing plants ${ }^{6}$. Large states attract more investments than smaller ones (because more interesting sites are available) and existing manufacturing activity makes a region more attractive for new establishments. Wage rate, population density, energy prices, and road infrastructure have no significant effect on the choice for a particular location in the US.

Following these early location studies, several scholars have extended these analyses by taking the country of origin of the investments into consideration (Friedman et al. 1992, Head et al. 1995, Shaver 1998, Woodward 1992, Wu and Strange 2000). Shaver (1998) analyses whether foreign-owned and US-owned establishments exhibit the same location patterns in US manufacturing industries in 1987. The 50 US-states clearly vary in attractiveness for foreign and local firms and these differences can not be attributed to the fact that foreign firms are relative latecomers in the US. Shaver (1998) finds that compared to US firms, foreign affiliates favour coastal areas more strongly ${ }^{7}$. Foreign firms also favour states with low unionisation rates and higher unemployment more than US firms. Several variables - the level of economic activity (measured by gross state product), corporate taxes and per capita income - do not exhibit statistically significant

\footnotetext{
${ }^{5}$ Carlton (1983) indicates that it is possible that energy is acting as a proxy for prices of other inputs which are heavily energy dependent or that the technology of new firms is more energy intensive than that of existing firms in the industry.

${ }^{6}$ This result implies that regions with high taxes are unattractive for new manufacturing establishments and high taxes therefore discourage new plants (Bartik 1985).

${ }^{7}$ Shaver (1998) emphasises that coastal areas likely enjoy transportation cost advantages when receiving imports from abroad compared to inland regions, making the economic benefit of location near the coast greater for foreign firms using those imports than for U.S. firms.
} 
coefficient estimates. Shaver (1998) therefore concludes that both foreign and local firms are equally attracted by these factors.

Friedman et al. (1992) use conditional logit modelling to analyse the location decisions of 884 new foreign multinational manufacturing enterprises in the United States. They separately study the site selections (between 1977 and 1988) of all foreign MNEs, Japanese MNEs, and European MNEs. Their results indicate that at the level of the individual state the following factors offer significant explanations for the choice for a particular US state: access to markets, labour market conditions ${ }^{8}$, state promotional efforts, transportation infrastructure, and taxes. The decision determinants are found to differ between Japanese and European firms. The former put much more emphasis on labour conditions, corporate taxes, and the number of potential sites (measured by total land area) than the latter.

Woodward (1992) uses a conditional logit model to analyse 540 Japanese-affiliated manufacturing investments in the United States for the period 1980-1989 ${ }^{9}$. He finds evidence that Japanese investors favour states with strong markets and low unionisation rates and dislike states with high taxes. Regional support from Japanese investment agencies located in the US (measured by home country office support) also facilitates new establishments in US states. Furthermore, Japanese firms generally select counties characterised by manufacturing agglomeration, low unemployment and poverty rates, and concentrations of educated, productive workers. In rural areas (the Michigan Tennessee automotive corridor), interstate highway connections positively influence the location of new Japanese investments while population density (signalling urbanisation) has no significant effect.

Head et al. (1995) examine the location choices of 751 new Japanese manufacturing plants in 225 four-digit manufacturing industries. These plants were built in the United States since 1980. Instead of looking at the individual regional characteristics, they consider agglomeration variables and employ state-specific constants to capture unobserved variation between states. They find that Japanese establishments do not simply mimic the geographical pattern of US establishments. Head et al. (1995)'s conditional logit estimates support the hypothesis that industry level agglomeration benefits play an important role in location decisions. Japanese's firms favour regions where there are already relatively many US establishment in the same industry. Furthermore, they choose locations that were also chosen by previous Japanese investors, either in the same industry, or from the same keiretsu.

\footnotetext{
${ }^{8}$ Friedman et al. (1992) find that unionisation positively influences the choice for a US state. They suspect that the decline in power of the unions in the 1980 s may have diminished the foreign firms' avoidance of states with higher unionisation rates. This result opposes the results of Bartik (1985) and Shaver (1998) who find that unionisation significantly reduces the attractiveness of a state.

${ }^{9}$ Woodward (1992) analyses both the choice for a particular state in the US (36 states were included that actually had Japanese establishments) and the choice for a particular county within the state. In the later case, this choice is compared to the characteristics of 9 alternative, surrounding counties.
} 
Cheng and Kwan (2000) estimate the effects of the determinants of foreign direct investment (FDI) in 29 Chinese regions (including the export-processing zones specifically targeted to receive FDI) from 1985 to $1995^{10}$. They find that a large regional market, good infrastructure, and preferential policy had a positive, but regional wage costs had a negative effect on FDI. In addition, there was a self-reinforcing effect of FDI on itself, consistent with agglomeration effects. Education levels had no significant effect on the attractiveness of a region in China.

Wu and Strange (2000) analyse the location choice of 138 foreign insurance companies from 11 home countries that opened representative offices in six cities in China during the period 1992-1996. They use conditional logit modelling in their analyses and find that proximity to the headquarters of the government's Regulatory Authority - that grants operating licenses for both life and non-life insurance - (measured as proximity to government institutes) is an important determinant explaining the establishment pattern of those foreign insurance companies. Furthermore, market size and the presence of other foreign investors are found to have significant positive effects upon the choice of location. Wu and Strange (2000) therefore find strong support for the assumption that foreign service firms are inclined to locate near agglomerations of (foreign) producers because such agglomerations provide proximity to competitors, to suppliers, to clients, and to a pool of skilled labour. Foreign insurance firms favour regions in China that are open to the award of operating licenses. Most regions are currently still closed for foreign investment and therefore unattractive as locations. Labour related variables are found to be of little significance.

Most studies look at the (economic) characteristics of regions within the host country but ignore the specific characteristics or purposes of the investing firm. One important exception is the study conducted by Kittiprapas and McCann (1999). Instead of looking only at the characteristics of the regions, they incorporate characteristics of the individual firm (such as size) as well. They analyse the establishment pattern of 156 electronics firms in 4 regions in Thailand. Using binomial logit to clarify the choice for Bangkok compared to the rest of Thailand, they find that both regional wage levels and Thai ownership positively influence the choice for Bangkok. Their findings suggest that the existence of localised agglomeration economies positively influence the attractiveness of regions.

Our understanding of this body of the literature suggests that the variables influencing the choice for a particular location within a host country (presented in Table 4.2) can broadly be classified in six groups: 1) agglomeration variables, 2) market variables, 3) labour variables, 4) government policy, 5) infrastructure, and 6) geographic variables. This classification results in the conceptual model of the determinants of regional location choice presented in Figure 4.2.

${ }^{10}$ Cheng and Kwan (2000) estimate the locational determinants within a Generalized Method of Moments (GMM) framework. Contrary to the other studies mentioned in Table 4.2 their dependent variable is the stock of FDI in the host region and not the actual establishment counts. 


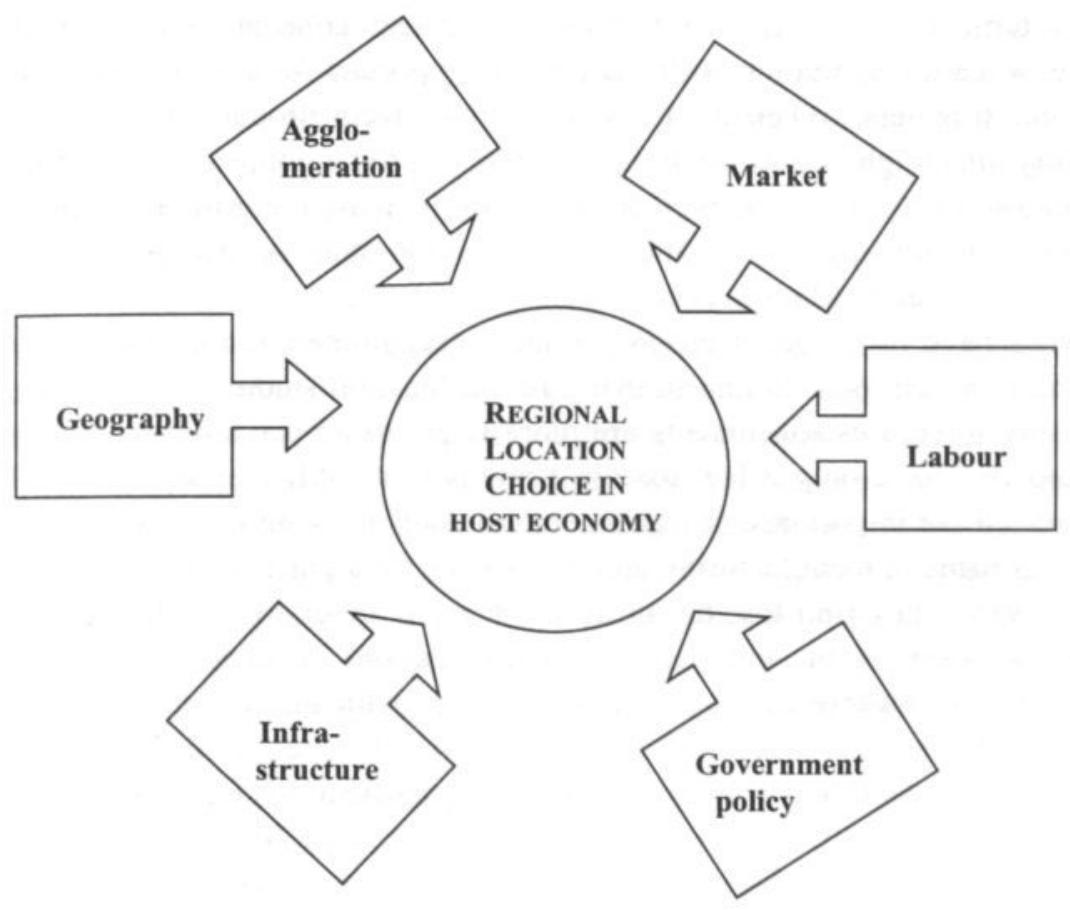

Figure 4.2

Determinants of regional location choice

\subsection{Hypotheses}

As shown in Table 4.2 and Figure 4.2, the variables influencing the regional location choice in a host economy can broadly be organised in six groups: agglomeration variables, market variables, labour variables, government policy, infrastructure, and geography. This section formulates hypotheses that apply to the Dutch situation for each of these groups of variables as specified in our conceptual model. The main potential determinants of foreign investors' regional location choice in the Netherlands are:

1. Agglomeration variables: Theoretical analysis has developed various explanations for manufacturing agglomeration. The early work of Marshall (1920) provides three reasons for spatial concentration in industries: (a) localisation provides a pooled market for workers with special skills, (b) facilitates the development of specialised inputs and (capital) services, and (c) enables firms to benefit from technological and knowledge spillovers. The revival of these ideas is due to Krugman (1991) who constructed a formal model to analyse agglomeration. Increasing returns to scale and the need and possibility to control transportation costs are vital aspects of the new theoretical contributions. 
Increasing returns to scale tend to foster geographical concentration of production. Furthermore, when transportation costs matter, it is important for a firm to be close to the customers and suppliers. When as a result of these facts production is concentrated geographically, this might attract the mobile factors of production, such as skilled labour. A concentration of those workers then leads to increased consumer demand in a particular location, making it even more attractive for other producers, resulting in a reinforcing pattern: success breeds success.

Several studies have investigated the importance of agglomeration as a determinant of location choice. A common finding in many recent location studies is that regions with relatively many foreign establishments are more likely to attract additional investments than locations that have only a few foreign firms present. Wheeler and Mody (1992) ${ }^{11}$ have investigated the importance of agglomeration economies on the foreign investment decision of US firms in manufacturing and electronics for a panel of 42 countries for the period 1982-1988. They find that the presence of many other foreign firms in a region (which can be seen as an indicator of agglomeration) matters significantly as a determinant of new FDI inflows. Furthermore, Braunerhjelm and Svensson (1996) ${ }^{11}$, who studied the establishment pattern of Swedish MNE affiliates abroad, find evidence supporting the importance of agglomeration effects, particularly for Swedish high-tech firms operating in the OECD countries. These firms tend to locate manufacturing affiliates in geographically well-defined areas specialised in similar production ${ }^{12}$. Barrell and Pain (1999) ${ }^{11}$ emphasise the importance of agglomeration effects in the location pattern of US affiliates in the European Union (EU). They pay particular attention to the effects of the process of EU-integration and the resulting increased attractiveness of the EU. They find that both centrifugal forces (pushing out foreign firms, such as high costs) and centripetal forces (attracting additional FDI, such as agglomerations of other foreign firms) matter for location decisions by US firms in the $\mathrm{EU}^{13}$. Head et al. (1995) find strong evidence supporting the positive effect of foreign agglomeration on location choice by 751 new Japanese plants built in the US since 1980. Given the overall positive influence of agglomeration, we expect that other foreign establishments will encourage new FDI into a region due to knowledge spillovers and supplier linkages. Thus our hypothesis regarding foreign agglomeration is as follows:

\section{H1: The presence of foreign establishments in a region positively influences new foreign investment in that region}

\footnotetext{
"Wheeler and Mody (1992), Braunerhjelm and Svensson (1996), and Barrell and Pain (1999) are not mentioned in table 4.2 because these studies analyse the characteristics of several host countries and not regions within one host country.

${ }_{12}$ Braunerhjelm and Svensson (1996) emphasise that both knowledge spillovers and "pecuniary" externalities - associated with demand and supply linkages, such as the possibility to use joint networks of suppliers and distributors - make up the most important agglomeration benefits.

${ }^{13}$ Barrell and Pain (1998) suggest that agglomeration economies arise from the presence of other firms in the region and the resulting business linkages, and the associated availability of skilled labour.
} 
Agglomeration may also occur around local firms. The expected effect of the presence of local firms can be either negative or positive. Like foreign establishments, a large number of local establishments could positively influence the attractiveness of the region due to knowledge spillovers and a large pool of skilled labour in the region. Bartik (1985), for instance, shows that the presence of existing manufacturing activities in a region attracts additional investments. Furthermore, Head et al. (1995) find that Japanese affiliates are attracted to regions in the US where many local US firms are located.

On the other hand, the presence of many local competitors may also be a deterrent to new investments due to the presence of local competitors and the expected rivalry. Furthermore, the pool of skilled labour might be too small for the number of firms present in the region, resulting in fierce competition for labourers and therefore in high costs. This point of view has not been tested before. Considering that foreign firms suffer from the liability of foreignness and are less familiar with Dutch business rules and customer taste, the presence of many local competitors with better market knowledge may deter the entrance of foreign affiliates in a region. We therefore propose the following two competing hypotheses regarding local agglomeration:

H2a: The presence of local establishments in a region positively influences new foreign investment in that region

$H 2 b$ : The presence of local establishments in a region negatively influences new foreign investment in that region

2. Market variables: As shown in Chapter two, many firms invest in a particular country or region to supply goods or services in these or adjacent countries. These market-seeking investments are undertaken to sustain or protect existing markets, or to exploit or promote new markets (Dunning 1993). Several studies therefore emphasise the importance of the market size in attracting additional investments to a region. Woodward (1992) models the locational determinants of 540 Japanese manufacturing start-ups in the United States (US). He finds that Japanese investors favour states with strong markets and low unionisation rates while they avoid less-developed areas with few educated workers, high unemployment and high state unitary taxes. Areas that are characterised by high GDP per capita are considered to have high (potential) demand for goods and services. High demand also results in possible economies of scale and therefore makes an area more attractive for investors. Following Woodward (1992) we therefore expect that a larger regional market will attract more new foreign establishments and hypothesise:

H3: A larger market size in a region positively influences new foreign investment in that region

3. Labour variables: Apart from market-seeking investments, foreign establishments can be motivated by resource-seeking arguments. Investments can be prompted by the 
need to acquire technological capability, management or marketing expertise, and organisational skills (Dunning 1993). Labour is an important income-generating asset for the firm and labour market conditions therefore are an important determinant of the attractiveness of a region. Several studies have proxied the available workforce by population density (see for instance Bartik 1985 and Woodward 1992, Table 4.2). We expect this variable to have a positive effect on the decision to locate in a particular region.

H4: A higher population density in a region positively influences new foreign investments in that region

Labour market conditions are also reflected in the level of unemployment in the region ${ }^{14}$. The effect of unemployment on the location decision of foreign firms is not easily decided beforehand. Following Carlton (1983) unemployment is considered for the following reasons. On the one hand, high unemployment can signal low local demand. Even though most establishments will target national markets, local spurts in demand (with which the unemployment variable is negatively correlated) could raise prices locally and thereby stimulate locational activity. Furthermore, high unemployment can signal a lack of suitable employees making a region unattractive for foreign firms. On the other hand, it is also possible that especially for larger firms, an area with a high unemployment rate might be attractive. A high unemployment rate can reduce the initial and subsequent costs of assembling and maintaining a workforce. High unemployment can then serve as a proxy for the available workforce (Woodward 1992). This argument is partially confirmed by Shaver (1998). Having no theoretical argument to prefer one argument over the other, we suggest two opposing hypotheses:

H5a: Higher unemployment in a region negatively influences new foreign investment in that region

H5b: Higher unemployment in a region positively influences new foreign investment in that region

4. Government policy: Most studies on FDI location take taxation differences into account (Bartik 1985, Woodward 1992, Shaver 1998). High taxes increase the costs of doing business in a particular location (partly also by the administrative burden) and therefore reduce profitability. This is particularly relevant for studies in the US, where

${ }^{14}$ Most location studies include unionisation of the region (Bartik 1985, Carlton 1983) as one of the labour-market variables but this is irrelevant in the Dutch situation. Unionisation is organised per industry rather than per region. Furthermore, regional data on differences in wages, skills and education level, productivity, and poverty are not available for the Netherlands and therefore have to be excluded. It is quite likely that within a small geographic area like the Netherlands these variations would be small and disregarding this variable should not cause a lot of problems. 
taxation levels differ significantly among states. However, this is not the case in the Netherlands. Tax levels are equal all over the country. The only tax-rate that differs is the real estate property tax, decided upon by individual cities. We expect that high property taxes will negatively influence the decision to locate in a particular region due to an increase in costs of doing business. We therefore hypothesise:

H6: Higher real estate property taxes in a region negatively influence new foreign investment in that region

5. Infrastructural variables: The choice for a particular region is influenced by the transport and communication costs incurred in that area. The infrastructural provisions therefore influence the attractiveness of a region for new investments (Dunning 1993). If an area is characterised by well-developed utilities and an extensive knowledge- and transportation infrastructure, this reduces the costs and increases the reliability of transportation and therefore makes the area more attractive for FDI (Cheng and Kwan 2000). This is particularly important if the goods produced at the location are targeting the export markets, which can be expected in a small economy. Particularly in case of the Netherlands, we expect many foreign firms to use the Netherlands as an export-hub for the rest of the European Union. Ease of transportation is then an important factor that determines the choice for a location in the Netherlands. Following Bartik (1985) we include roads per area as an indicator of the sophistication of the infrastructure in a region. We expect this variable to have a positive influence on the decision to locate an affiliate in a region. Better infrastructure ${ }^{15}$ results in better accessibility of a region and easier access to other region (or countries) which facilitates the distribution of both inputs and outputs. Thus our hypothesis regarding the quality of infrastructure is as follows:

H7: Large infrastructural provisions in a region positively influence new foreign investment in that region

It would have been interesting to consider other infrastructural measures such as knowledge infrastructure etc. particularly since those are important in the services sector that attracts a lot of FDI in the Netherlands. However, statistics on these variables are currently not available on a regional level.

6. Geographic variables: The geographical size of a region can affect the number of sites available to decision-makers. The larger the area, the more sites potentially available to an investor and therefore the more attractive the area is for foreign investment. We therefore expect land area to have a positive effect on the probability of a region being

${ }^{15}$ In this study better means more roads per $\mathrm{km}^{2}$ area. 
chosen (Bartik 1985, Friedman et al. 1992, Woodward 1992), resulting in the following hypothesis:

H8: A large available area in a region positively influences new foreign investment in that region

A number of studies have found a preference of foreign investors to locate in a region close to their home country (Head et al. 1995). This can result in a cost advantage in case intermediary inputs have to be transported to the affiliate (Shaver 1998). Furthermore, we can expect a cultural similarity in bordering regions that facilitates doing business there. We therefore expect firms from Japan and the US to favour other Dutch regions than European establishments. Particularly German and Belgian firms are expected to favour regions neighbouring their countries (such as Noord Brabant, Limburg, Gelderland, see Figure 4.1). We thus suggest the following hypothesis:

H9: Multinationals from countries that have a border with the Netherlands are more inclined to invest in regions that are attached to their home country than firms from countries that are no direct neighbours.

Figure 4.3 summarises the hypotheses presented in this section. So far no study has analysed the combined effect of these variables on the regional location choice in the Netherlands. The model extends the macro-economic analyses conducted in Chapter 3 by taking the characteristics of the chosen region into account. Furthermore, instead of looking at the determinants of the overall inward investment flow in the Netherlands, we know consider the individual establishments of MNEs and their choice for a particular region in the Netherlands.

\begin{tabular}{|c|c|c|}
\hline $\begin{array}{l}\text { Agglomeration } \\
\text { H1: Foreign establishments } \\
\text { H2: Local establishments } \\
\text { Market variables } \\
\text { H3: Market size } \\
\text { Labour variables } \\
\text { H4: Population density } \\
\text { H5: Unemployment } \\
\text { Government policy } \\
\text { H6: Property taxes } \\
\text { Infrastructural variables } \\
\text { H7: Infrastructure } \\
\text { Geographic variables } \\
\text { H8: Area }\end{array}$ & $\begin{array}{l}(+) \\
(+/-) \\
(+) \\
(+) \\
(+/-) \\
(-) \\
(+) \\
(+)\end{array}$ & $\begin{array}{c}\text { REGIONAL } \\
\text { LOCATION } \\
\text { CHOICE }\end{array}$ \\
\hline H9: Border countries & $(+)$ & $\begin{array}{l}\text { Figure } 4.3 \\
\text { Hypothesised relationships }\end{array}$ \\
\hline
\end{tabular}




\subsection{The Model}

We model the location decision of foreign firms in the Netherlands as a conditional logit problem where the dependent variable is the area in the Netherlands chosen by each investor $^{16}$. We follow the method successfully employed in earlier studies such as Carlton (1983), Bartik (1985), Woodward (1992), Head et al. (1995), and Shaver (1998). The models are based on McFadden's model $(1974,1978)$. All studies investigate the odds of locating in a particular region and assume that each investor will make the location choice for its affiliate on the basis of trying to maximise the expected future profits from its investment. These future profits depend upon a number of attributes of each potential region. These attributes all have an effect on future revenues and costs. Therefore, the decision for a specific location takes into account the attributes of the chosen location relative to the other alternative locations. A foreign firm will choose the Dutch region that yields the highest profit.

Following our conceptual model presented in figure 4.2, regional location choice can be considered a function of six sets of variables: (1) agglomeration effects (A); (2) market variables (M); (3) labour variables (L); (4) government policy as measured by taxes (T); (5) infrastructure (I); and (6) geographic variables $(\mathrm{G})$. We can therefore consider the location choice of foreign establishments $\left(\mathrm{L}_{\mathrm{f}}\right)$ as:

$$
\mathrm{L}_{\mathrm{f}}=\mathrm{g}(\mathrm{A}, \mathrm{M}, \mathrm{L}, \mathrm{T}, \mathrm{I}, \mathrm{G})
$$

The profits of a new establishment $\mathrm{t}$ at location $\mathrm{j}\left(\pi_{\mathrm{jt}}\right)$ are a function of a vector of observed characteristics $\mathrm{Xj}$ of the site $\mathrm{j}$ (where $\mathrm{X}=\{\mathrm{A}, \mathrm{M}, \mathrm{L}, \mathrm{T}, \mathrm{I}, \mathrm{G}\}$ ) plus a disturbance term $\varepsilon_{j t}{ }^{17}$ or

$$
\pi_{j t}=\beta^{\prime} X_{j}+\varepsilon_{j t}, \quad \mathrm{j}=1, \ldots, \mathrm{J}
$$

Location $\mathrm{j}$ is one of the 12 provinces in the Netherlands ${ }^{18}$. $\beta$ is a vector of parameters to be estimated. Following McFadden $(1974,1978)$, we assume that the disturbance terms

\footnotetext{
${ }^{16}$ This choice is dictated by the available data. For each MNE active in the Netherlands, the DutchInvestdatabase reports data on the city and province where the affiliate is located. Every affiliate is counted as one observation. Given that no data are available that indicate the size of the investment (either the initial investment or current size in terms of total assets or employment) we are forced to treat all affiliates in the same way. We know which Dutch province they have favoured for their activities, even though the other 11 provinces in the Netherlands would have been alternative locations. The choice for a region given the existence of alternative regions can be modelled using conditional logit. For each observation (in this case for each affiliate), the chosen region (province) is given the value 1 , while the 11 alternative regions are 0. ${ }^{17} \varepsilon_{j \mathrm{j}}$ reflects the unique advantages of province $\mathrm{j}$ to company $\mathrm{t}$. It differs across countries for any one firm and across firms for any one country (Carlton 1983).

${ }^{18}$ If only two choices are considered $(\mathrm{J}=2)$ the model reduces to a binary discrete choice model.
} 
are independent and identically distributed (iid) according to the Weibull distribution. Under this assumption the probability of locating an establishment $\mathrm{t}$ at location $\mathrm{j}$ is given by the logit expression:

$$
\operatorname{Pr}[\text { region } \mathrm{j}]=\frac{e^{\beta^{\prime} X_{j t}}}{\sum e^{\beta^{\prime} X_{j t}}}
$$

Estimations of $\beta$ may be obtained with maximum likelihood estimation ${ }^{19}$.

\subsection{The data}

Two types of data are used for this study. The first dataset contains information on new foreign establishments in the Netherlands. We consider both a five-year period running from 1992 to 1996 and a subset of this data set covering the years 1995-1996. Our study comprises 1435 (357) new foreign establishments from 40 (24) home countries. An overview of the countries and the numbers of new foreign affiliates from those countries is given in Table 4.3 for both time periods.

The establishment data are taken from the DutchInvest database (for a full description of the database see Section 2.8 and Appendix A at the end of this book). This database was created to analyse Dutch inward FDI at the micro-level. We have collected information on all known affiliates that started activities in the Netherlands in the period up to $1997^{20}$ and are still in business. For all firms the database reports their location in the Netherlands, their main SIC-activity, the year of establishment (and occasionally of takeover), number of employees, and identity and home country of the parent. Each affiliate is counted as one observation.

We acknowledge the fact that lists of firms are never exhaustive, up-to-date, and fully accurate. We have therefore combined several sources to make the database as extensive as possible. First of all, we have used the 1996 and 1997 Dun \& Bradstreet CDs to locate

\footnotetext{
${ }^{19}$ Alternatively, we can follow an adaptation of the McFadden-model as discussed by Head et al. (1995). Following this model avoids having to specify all individual regional characteristics, such as wages, unionisation rates, energy prices, and access to ports. A possible problem with that approach stems from the near impossibility of selecting and correctly measuring all relevant sectoral variables. Instead, Head et al. (1995) only consider agglomeration. In this study we use both specifications. We model location choice considering only agglomeration of local and foreign firms, but also specify individual characteristics of the region for each of the six groups of variables, in an attempt to capture the significance of individual regional attractions.

${ }^{20}$ Occasionally we could also add information on establishments or take-overs of a more recent date. However, for the years following 1997 data are incomplete. For 1999, the City of Amsterdam alone reported 94 new establishments (Amsterdam the Newsletter, no. 5.5; 25 May, 2000), a new record. These firms, however, do not appear in the official directories yet and are therefore more difficult to trace and not always included in our sample.
} 
a large number of foreign firms conducting activities in the Netherlands ${ }^{21}$. Furthermore, the database has been complemented with firms listed in the ABC-Directory of Firms (1999). Japanese firms with Dutch affiliates that were listed by JETRO were also included. To check the information achieved in this way, we traced all firms in our list on the 1999 REACH-A database (review and analysis of companies in Holland). That way missing data were added and locations and activities were verified. This search resulted in a database of 7484 foreign establishments. A geographical overview of the regional distribution of these foreign firms is given in Figure 4.1.

Table 4.3 Counts and home countries of new foreign establishments in the Netherlands

\begin{tabular}{|c|c|c|c|c|c|}
\hline Country & $1995-1996$ & $1992-1996$ & Country & $1995-1996$ & $1992-1996$ \\
\hline Aruba & & 1 & Liechtenstein & \multirow{9}{*}{4} & 1 \\
\hline Australia & 3 & 15 & Luxembourg & & 30 \\
\hline Austria & 4 & 11 & Malaysia & & 2 \\
\hline Belgium & 47 & 146 & Mexico & & 1 \\
\hline Brazil & & 1 & New Zealand & & 1 \\
\hline Canada & 3 & 16 & Norway & & 4 \\
\hline Denmark & 7 & 20 & Philippines & & 1 \\
\hline Fed. Rep. Germany & 54 & 239 & Portugal & & 3 \\
\hline Finland & 2 & 5 & Russian Fed. & & 1 \\
\hline France & 23 & 58 & Singapore & \multirow[t]{2}{*}{1} & 5 \\
\hline Georgië & & 1 & South Africa & & 1 \\
\hline Hong Kong & 1 & 8 & Spain & 5 & 14 \\
\hline Hungary & & 1 & Surinam & 1 & 1 \\
\hline India & & 2 & Sweden & 7 & 28 \\
\hline Indonesia & & 1 & Switzerland & 9 & 58 \\
\hline Ireland & 4 & 26 & Taiwan & \multirow[t]{2}{*}{2} & 16 \\
\hline Israel & 4 & 17 & Turkey & & 2 \\
\hline Italy & 5 & 35 & UAE & 1 & 1 \\
\hline Japan & 17 & 81 & United Kingdom & 71 & 263 \\
\hline Republic of Korea & 3 & 9 & United States & 79 & 309 \\
\hline \multicolumn{4}{|l|}{ Total new } & 357 & 1435 \\
\hline
\end{tabular}

Source: DutchInvest database

The second set of data contains information on the region-specific economic data. Due to limited data availability, the number of regions considered was restricted to the 12 provinces of the Netherlands, listed in Table $4.1^{22}$. Although they are mainly administrative entities, they do differ due to their language, culture, or history. Considerable effort was spent to make the dataset as accurate as possible. Table 4.4 lists all the independent variables used in this model, their definition and source, and the

\footnotetext{
${ }^{21}$ Carlton (1983) also bases his analyses on Dun and Bradstreet data. He acknowledges that they are not flawless, but reasonably accurate and since no comparable data source is available, it provides the most detailed list of establishments.

${ }^{22}$ Ideally, we would have liked to test the choice of a region within the Netherlands over any region in the European Union. However, the data and time demands for such an exercise are so huge, that it is beyond the scope of a Ph.D. thesis.
} 
expected signs of their influence on the choice of a region for the establishment of an affiliate (see also Figure 4.3). For all independent variables we considered the situation at the beginning of the period studied for the five year (two year) sample: January 1992 (1995). We use a small subset of the data to reduce the potential variation in relative infrastructure levels and factor prices that could also influence a location's attractiveness. Most variables are considered as logarithms, with the exception of unemployment, which is already a percentage, so taking the logarithm is not needed for readily interpretable coefficients.

Table 4.4 Explanatory variables

\begin{tabular}{|l|l|c|l|}
\hline Variable & Definition & $\begin{array}{c}\text { Hypothesised } \\
\text { effect }\end{array}$ & Source \\
\hline Foreign agglomeration & Ln (number of foreign establishments) & + & DutchInvest \\
$\begin{array}{l}\text { Local agglomeration } \\
\text { Market size }\end{array}$ & Ln (number of local establishments) & $?$ & CBS \\
$\begin{array}{l}\text { Population density } \\
\text { Unemployment rate }\end{array}$ & Ln (Gross National Product of region) & + & CBS \\
Real estate taxes & $\begin{array}{l}\text { Average unemployment rate per region } \\
\text { Ln (amount of real estate taxes per } \\
\text { individual firm) }\end{array}$ & $?$ & CBS \\
$\begin{array}{l}\text { Infrastructure } \\
\text { Land area } \\
\text { Country dummy }\end{array}$ & $\begin{array}{l}\text { Ln (roads per } \mathrm{km}^{2} \text { land area) } \\
\text { Lumand Area in } \mathrm{km}^{2} \text { ) } \\
\text { Dummy for establishments from particular } \\
\text { countries (EU, US, Japan) } \\
\text { Dummy for Manufacturing and Holding } \\
\text { firms }\end{array}$ & + & CBS \\
Sector dummy & + & CBS \\
\hline
\end{tabular}

We added two groups of control variables to the model: country and sector dummy variables. Regarding the home country of the investor, we introduced a dummy variable for the European Union (EU) countries. Given that the Netherlands is part of the EU we wanted to control for the effects of EU integration in the analyses. Furthermore, we also separated the US investors from the total sample, considering that the US is the largest single home country of investments in the Netherlands. Japanese investments are unique because they only started in the 1980s. We therefore also controlled for their presence by introducing a Japan dummy in the analyses.

We also control for the different sectors in the sample by introducing dummy variables for manufacturing firms and holding companies. We expect that manufacturing firms need more space and will therefore favour locations outside the overcrowded Randstadarea where transportation is hindered by traffic jams. Holding firms ${ }^{23}$ have an exceptional position in the Netherlands (DNB 2000a). Most of them concentrate on financing and facilitating the multinational's activities. Given the nature of their activities, we expect them to favour the Randstad-area.

${ }^{23}$ In this study, all those firms that report SIC code 671 to be their main activity in the Dun \& Bradstreet reports are classified as holdings. Usually they employ only one or a few people. 


\subsection{Results}

Section 4.2 (Table 4.1) has shown that foreign firms in the Netherlands show a significantly different establishment pattern from local firms. Foreign firms appear to cluster together in just a few Dutch regions, particularly in the Randstad while they have very little interest in opening plants or offices in the other provinces. Using the model specified in Section 4.5 (Equation 4.3), we now test which factors determine the actual choice of a particular region or province in the Netherlands for foreign firms. In this section, a description of the results is given. A discussion of the results follows in section 4.8 .

Given the strong interest in Randstad areas, we first test a binary discrete choice model using LIMDEP 7.0, with Randstad or not as dependent variable. The results are given in Table 4.5 under specification 1 and 2 for the shorter period 1995-1996 and in specifications 3 and 4 for the total period of five years. Specifications 1 and 3 do not include regional characteristics, testing the importance of agglomeration in isolation, while specifications 2 and 4 do. Furthermore, in specifications 2 and 4 we can also test the dummy variables related to sector and home country to determine whether certain kinds of firms have a special preference for the Randstad and also whether firms from particular home countries (Japan, US) or areas (EU) are more inclined to opt for the Randstad than for the rest of the Netherlands.

Having tested factors that explain the choice for the Randstad or the rest of the Netherlands, we further disaggregate the data to determine the choice for one of the 12 Dutch provinces. We have estimated the model with the statistical programme STATA. Again the results are presented in Table 4.5. Specifications 5 and 7 exclude individual specifications of regional aspects while specifications 6 and 8 include them.

Since we have taken the logarithms of the independent variables, the results of all variables have interpretations as being proportional to the change in the probability of foreign investment in a region that results from a 1 percent change in the independent variable. Therefore a direct comparison between coefficient magnitudes of different variables can reveal which factors exert the most influence on location selection by foreign firms in the Netherlands.

Unfortunately, we run into multicollinearity problems when including the regional characteristics in the models ${ }^{24}$. We are therefore unable to test all related variables at the same time. The results presented have the maximum number of variables included. We cannot estimate dummy variables related to sector and home country in the conditional logit models (6 and 8 ) due to lack of within-group variance of the dummies and multicollinearity in the data. We therefore estimated more limited models, considering as many variables as possible. The results of these models are presented in Table 4.5.

\footnotetext{
${ }^{24}$ Highly correlated variables include local and foreign agglomeration, both agglomeration variables and market size, local agglomeration and area, and foreign agglomeration and property taxes.
} 
Table 4.5 Regression results

\begin{tabular}{|c|c|c|c|c|c|c|c|c|}
\hline Specification & 1 & 2 & 3 & 4 & 5 & 6 & 7 & 8 \\
\hline Years & \multicolumn{2}{|c|}{$1995-1996$} & \multicolumn{2}{|c|}{$1992-1996$} & \multicolumn{2}{|c|}{$1995-1996$} & \multicolumn{2}{|c|}{$1992-1996$} \\
\hline Regions & \multicolumn{4}{|c|}{ Randstad or not } & \multicolumn{4}{|c|}{12 Provinces } \\
\hline Constant & $\begin{array}{l}17.8^{\circ .0} \\
(5.84)\end{array}$ & $\begin{array}{r}-159.1^{\ldots} \\
(37.81)\end{array}$ & $\begin{array}{r}14.58^{\circ *} \\
(2.81)\end{array}$ & $\begin{array}{r}23.70 \\
(22.78)\end{array}$ & & & & \\
\hline Local agglomeration & $\begin{array}{r}-7.12^{\cdots} \\
(1.10)\end{array}$ & $\begin{array}{r}-36.2 \cdots \\
(6.45)\end{array}$ & $\begin{array}{r}-5.94^{\cdots} \\
(0.49)\end{array}$ & $\begin{array}{r}19.49^{* *} \\
(5.88)\end{array}$ & $\begin{array}{r}0.24 \\
(0.23)\end{array}$ & $\begin{array}{r}-1.66 \\
(1.63)\end{array}$ & $\begin{array}{r}-0.04 \\
(0.11)\end{array}$ & $\begin{array}{r}-0.09 \\
(0.13)\end{array}$ \\
\hline Foreign agglomeration & $\begin{array}{c}9.01^{\cdots} \\
(1.14)\end{array}$ & $\begin{array}{l}8.01^{\cdots *} \\
(1.30)\end{array}$ & $\begin{array}{l}7.68^{* \cdots} \\
(0.50)\end{array}$ & $\begin{array}{l}5.44^{* *} \\
(1.25)\end{array}$ & $\begin{array}{l}0.76 \\
(0.12)\end{array}$ & $\begin{array}{l}0.82^{\cdots} \\
(0.32)\end{array}$ & $\begin{array}{l}0.92^{\cdots} \\
(0.06)\end{array}$ & $\begin{array}{l}0.96 \\
(0.07)\end{array}$ \\
\hline Market size & & $\begin{array}{r}27.88^{* * *} \\
(5.57)\end{array}$ & & $\begin{array}{l}-9.17^{*} \\
(4.05)\end{array}$ & & $\begin{array}{r}0.67 \\
(0.86)\end{array}$ & & $\begin{array}{r}0.38 \\
(0.77)\end{array}$ \\
\hline Population density & & & & & & $\begin{array}{r}1.46 \\
(1.88)\end{array}$ & & $\begin{array}{r}-0.63 \\
(0.98)\end{array}$ \\
\hline Infrastructure & & $\begin{array}{r}0.74 \\
(0.63)\end{array}$ & & & & $\begin{array}{r}0.03 \\
(1.11)\end{array}$ & & $\begin{array}{r}0.29 \\
(0.77)\end{array}$ \\
\hline Property tax & & & & & & $\begin{array}{r}-2.55 \\
(2.89)\end{array}$ & & $\begin{array}{r}0.59 \\
(1.64)\end{array}$ \\
\hline Unemployment & & $\begin{array}{l}0.58^{* *} \\
(0.29)\end{array}$ & $\begin{array}{r}0.18 \\
(0.25)\end{array}$ & & & 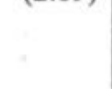 & & $\begin{array}{r}-0.04 \\
(0.04)\end{array}$ \\
\hline Land area & & & $\begin{array}{r}-14.71^{\cdots} \\
(2.36)\end{array}$ & & & $\begin{array}{r}1.12 \\
(1.31)\end{array}$ & & $\begin{array}{r}-0.14 \\
(0.73)\end{array}$ \\
\hline Manufacturing & & $\begin{array}{r}0.78 \\
(0.81)\end{array}$ & & & & & & \\
\hline Holding & & $\begin{array}{l}1.44^{\circ} \\
(0.87)\end{array}$ & $\begin{array}{c}1.06^{* *} \\
(0.39)\end{array}$ & & & & & \\
\hline $\mathrm{EU}$ & & $\begin{array}{r}0.35 \\
(0.61)\end{array}$ & & & & & & \\
\hline US & & & $\begin{array}{l}0.85^{*} \\
(0.31)\end{array}$ & & & & & \\
\hline Japan & & & $\begin{array}{r}(0.31) \\
1.22^{\circ} \\
(0.62)\end{array}$ & & & & & \\
\hline
\end{tabular}


Table 4.5 Regression results (continued)

\begin{tabular}{|c|c|c|c|c|c|c|c|c|}
\hline Specification & 1 & 2 & 3 & 4 & 5 & 6 & 7 & 8 \\
\hline Years & \multicolumn{2}{|c|}{$1995-1996$} & \multicolumn{2}{|c|}{ 1992-1996 } & \multicolumn{2}{|c|}{ 1995-1996 } & \multicolumn{2}{|c|}{$1992-1996$} \\
\hline Regions & \multicolumn{4}{|c|}{ Randstad or not } & \multicolumn{4}{|c|}{12 Provinces } \\
\hline Log likelihood & -103.2 & -62.6 & -437.2 & -250.7 & -688.8 & -687.5 & -2733.6 & -2731.3 \\
\hline Restricted log likelihood & -245.73 & -245.7 & -978.2 & -977.3 & & & & \\
\hline $\begin{array}{l}\chi^{2} \\
\text { Number of choosers }\end{array}$ & $285.1^{\cdots *}$ & $366.2^{\cdots *}$ & $1080.4 \cdots$ & $1453.2^{\cdots \cdots}$ & & & & \\
\hline $\begin{array}{l}\text { Number of choosers } \\
\text { Number of choices }\end{array}$ & 357 & 357 & 1434 & 1434 & 357 & 357 & 1434 & 1434 \\
\hline Number of choices & 2 & 2 & 2 & 2 & 12 & 12 & 12 & 12 \\
\hline
\end{tabular}

Notes: standard errors are shown in parentheses

${ }^{*}$ significant at the 1 percent level, ${ }^{*}$ at the 5 percent level, ${ }^{\circ}$ at the 10 percent level.

Variables that could not be tested due to multicollinearity problems are omitted from this table. 
The results from specifications 1-8 are generally consistent with the expectations in the hypotheses and show the expected signs of relationship between location choice and determining factors. However, particularly for the regional characteristics, only a few variables actually are significant. Table 4.6 gives an overview of the hypotheses and the test results. We separately look at the results of the analyses for the Randstad-area (specifications 1-4) and for the 12 provinces (5-8).

\section{Table 4.6 Hypotheses tests}

\begin{tabular}{|c|c|c|c|}
\hline Hypothesis & \multicolumn{2}{|c|}{ Confirmed? } \\
\cline { 3 - 4 } & Randstad & Provinces \\
\hline 1 & $\begin{array}{l}\text { The presence of foreign establishments in a region positively influences } \\
\text { new foreign investment in that region }\end{array}$ & Yes & Yes \\
\hline $2 \mathrm{a}$ & $\begin{array}{l}\text { The presence of local establishments in a region positively influences } \\
\text { new foreign investment in that region } \\
\text { The presence of local establishments in a region negatively influences } \\
\text { new foreign investment in that region }\end{array}$ & No & Yes \\
\hline 3 & $\begin{array}{l}\text { A larger market size in a region positively influences new foreign } \\
\text { investment in that region }\end{array}$ & Yes & No \\
\hline 4 & $\begin{array}{l}\text { A higher population density in a region positively influences new } \\
\text { foreign investments in that region }\end{array}$ & \# & No \\
\hline $5 \mathrm{a}$ & $\begin{array}{l}\text { Higher unemployment in a region negatively influences new foreign } \\
\text { investment in that region }\end{array}$ & No \\
\hline $5 b$ & $\begin{array}{l}\text { Higher unemployment in a region positively influences new foreign } \\
\text { investment in that region }\end{array}$ & No \\
\hline 6 & $\begin{array}{l}\text { Higher real estate property taxes in a region negatively influence new } \\
\text { foreign investment in that region }\end{array}$ & \# & No \\
\hline 7 & $\begin{array}{l}\text { Larger infrastructural provisions in a region positively influence new } \\
\text { foreign investment in that region }\end{array}$ & Yes & No \\
\hline 8 & $\begin{array}{l}\text { A larger available area in a region positively influences new foreign } \\
\text { investment in that region }\end{array}$ & No \\
\hline 9 & $\begin{array}{l}\text { Multinationals from countries that have a border with the Netherlands } \\
\text { are more inclined to invest in regions that are attached to their home } \\
\text { country than firms from countries that are no direct neighbours }\end{array}$ & Yes & Yes \\
\hline
\end{tabular}

For this hypothesis we find significant results opposing the suggested relationship \# not tested due to multicollinearity problems

Regarding the agglomeration variables, we find the following results. When testing for the differences between locating in the Randstad-area (including parts of Noord Holland, Zuid Holland, and Utrecht) and the rest of the Netherlands we find that foreign agglomeration positively influences the choice of new foreign establishments for the Randstad. For the test of the location choice for one of the twelve provinces, we also find a significant positive influence of the presence of other foreign firms. Therefore, the overall results offer strong support for hypothesis one. Foreign firms tend to follow their predecessors, trusting their choice and hoping for positive spillovers from clustering. The presence of many local firms turns out to be a significant deterrent for new foreign establishments in the Randstad in most specifications, in line with hypothesis $2 \mathrm{~b}$. For the 
larger sample, when including the location characteristics, the presence of Dutch firms appears to encourage additional investments in the Randstad, a result in line with hypothesis 2a. For the choice for any of the 12 Dutch provinces, we find that local firms have a negative but insignificant influence on the choice to locate in their neighbourhood. These results offer no support for either hypothesis $2 \mathrm{a}$ or $2 \mathrm{~b}$. Overall, we find that the presence of local competition in the market appears to discourage foreign firms from locating in regions in the Netherlands when the choice is between Randstad and the rest.

Regarding the market variable (market size) specifications 2, 6, and 8 appear to confirm the expectation that a larger market attracts more foreign investors (hypothesis 3), although only in the case of specification 2 is this result significant at the 1 percent level. However, in specification 4 we find significant proof of the opposite effect. The effect is therefore inconclusive.

The effect of the labour variables is small and insignificant in most specifications. Due to multicollinearity problems, population density could only be tested in the conditional logit model for the small sample (1995-1996). Although the parameter is correctly signed, confirming our expectation that a high population density increases the likelihood of foreign investment, the effect is not significant. We therefore cannot confirm hypothesis four based on our results. The influence of unemployment is positive for both specifications regarding the choice between the Randstad and the rest of the Netherlands. It is significant only in specification 2 . We therefore find some support for hypothesis $5 \mathrm{~b}$. For the choice among provinces we find the opposite effect, but this is not significant.

The influence of government policy is measured by the property taxes variable. Its effect is small, positive, but insignificant in case of the large sample specification 8. Although this result is contrary to our expectation, the lack of significance restrains us from basing solid conclusions on this result.

The infrastructure in the area, measured by the road density, exerts a positive but insignificant influence of foreign establishments in estimations 2, 6, and 8. However, when testing the same variables listed in specification 2 for the large sample (not shown in Table 4.5), infrastructure does exert a large, positive and significant influence on the choice for the Randstad area ${ }^{25}$. Hypothesis seven is therefore confirmed for the Randstad. Land area has a significant negative influence in specification 6. This finding contradicts our expectations in hypothesis 8 . We therefore reject hypothesis eight that a larger area available to foreign investors encourages establishments of foreign firms.

Hypothesis nine explored the relationship between home country and location choice. From the results for the larger sample it is clear that relative to European and other firms, Japanese and US firms favour the Randstad more. When testing the variables of specification 2 for the large sample (not shown in Table 4.5), we find a strong and significant negative influence of EU on the choice for the Randstad ${ }^{26}$. This relationship is

\footnotetext{
${ }^{25}$ Infrastructure $\beta=22.9 * \cdots(\mathrm{SE}=4.9)$.

${ }^{26} \mathrm{EU} \beta=-0.50^{* *}(\mathrm{SE}=0.23)$.
} 
further explored in Table 4.7 where we take a closer look at the establishment patterns of German, Belgian, UK, US, Japanese, and all European establishments. We expect Japanese and US firms to value the transportation facilities in the Randstad area more, given their distance from the Netherlands. On the other hand, affiliates whose parents are in neighbouring countries may be more inclined to choose the border-regions that are closest to their home. We test our expectations with $\chi^{2}$ tests.

Table 4.7 New establishments per region of firms from different home countries (1992-96)

\begin{tabular}{|l|r|r|r|r|r|r|r|}
\hline Region & All & US & UK & Germany & Belgium & Japan & All Europe \\
\hline Groningen & 11 & 2 & 2 & $\mathbf{3}$ & 1 & 2 & 7 \\
Friesland & 13 & 2 & 5 & 3 & - & 1 & 9 \\
Drenthe & 14 & 5 & 2 & $\mathbf{5}$ & 1 & - & 8 \\
Overijssel & 32 & 6 & 4 & $\mathbf{1 2}$ & 3 & 2 & 21 \\
Gelderland & 104 & 20 & 15 & $\mathbf{3 2}$ & 12 & 2 & 72 \\
Utrecht & 145 & 42 & 21 & 31 & 10 & 7 & 81 \\
Noord Holland & 416 & 104 & 86 & 41 & 16 & 41 & 225 \\
Zuid Holland & 357 & 70 & 69 & 47 & 36 & 12 & 218 \\
Zeeland & 16 & 1 & 3 & 3 & $\mathbf{5}$ & - & 12 \\
Noord Brabant & 230 & 39 & 41 & $\mathbf{3 9}$ & $\mathbf{4 7}$ & 7 & 159 \\
Limburg & 71 & 16 & 8 & $\mathbf{1 5}$ & $\mathbf{1 3}$ & 5 & 47 \\
Flevoland & 26 & 2 & 7 & 8 & 2 & 2 & 19 \\
$\chi^{2}{ }^{2}$ & & NS & NS & $44.35^{*}$ & & & NS \\
$\chi_{8}^{8}$ & & & & & $54.23^{\circ}$ & & \\
\hline
\end{tabular}

- Significant at the 0.005 percent level, Neighbouring regions are shown in bold

$\chi^{2}$ tests can be applied if every cell has at least 1 observation and no more than $20 \%$ of the cells have less than five observations. To meet these requirements, we have grouped the observations in the Northerm provinces Friesland, Groningen and Drenthe. The number of degrees of freedom is reduced to nine. For Belgium, we also combined Flevoland and Noord Holland. For Japan, too many aggregations are needed to allow for $\chi^{2}$ testing.

From Table 4.7 it is clear that establishment patterns differ significantly per home country. Hypothesis nine is confirmed by the data. Firms that have a parent in Belgium and Germany favour neighbouring regions over the rest of the Netherlands. We also can see from the establishment data that the Japanese establishments favour Randstad locations in Noord- and Zuid Holland (65\%). For all other countries tested (US, UK, and all EU), the establishment pattern resembles that of all foreign firms.

For the Randstad or rest of the Netherlands specifications (2 and 6) we also tested the importance of the kind of activity conducted by the foreign affiliate on its location choice. We find strong and significant evidence that, relative to all other establishments, the holding companies tend to favour the Randstad area.

\subsection{Discussion}

Our main objective in this chapter was to test the influence of regional economic variables on the foreign affiliate's choice for a particular location in the Netherlands. To 
this end, we explored the relationship of six groups of variables (agglomeration, market, labour, government, infrastructure, and geography) on the location choice of a large number of foreign establishments in the Netherlands. The results of this study are important for several reasons.

First of all, they strongly support the importance of agglomerations of foreign firms for the attractiveness of a region for new foreign start-ups. This result confirms earlier studies by Head et al. (1995) and Wu and Strange (2000). The analyses support the notion that foreign firms like to cluster around other (previous) foreign establishments to benefit from agglomeration economies (resulting for instance from a pool of specialised labour and inputs and technical and knowledge spillovers among firms). Future research could explore the relationship between agglomerations of firms from the same home country and new/additional investments by other firms from that home country. We could then establish whether it is overall agglomeration that is attractive, or whether the nationality of the firms matters, for example because it facilitates communication between firms.

The positive and significant explanatory power of the foreign agglomeration measure has important policy implications. As agglomeration economies tend to give rise to virtuous circles, inward FDI is likely to create a cumulative mechanism, in which past inflows engender current and future flows into the host economy. This implies that countries that already attract FDI are those most likely to continue to do so (Nachum 2000). Therefore, any benefits received from attracting a single investment will be magnified by an increased probability of attracting subsequent similar investments. Governments can therefore target foreign firms with incentive programs creating such a virtuous circle (Mudambi 1995) ${ }^{27}$. These firms will then act as "magnets" for additional foreign investments into a region. However, we would not recommend this policy for the northern regions in the Netherlands. It is likely that a certain threshold of foreign firms needs to be reached before the agglomeration effect will kick in. Subsidising enough foreign investments into these region (that from our overall analysis appear to be very unattractive for foreign firms) to encourage spontaneous additional investments may not be economically viable. It would be interesting to evaluate the role of (financial) incentives in the final site selection process. This would require intensive survey research, asking all individual start-ups on the importance of offered incentives (if any). Given that it is not official Dutch government policy to engage in subsidisation of foreign establishments, we did not conduct that analysis for our present study.

The results for the choice between the Randstad and the rest of the Netherlands show that the presence of many local firms can act as a deterrent to new foreign establishments. This result contradicts earlier studies by Bartik (1985), Head et al. (1995) and Woodward (1992). These studies all emphasise the importance of agglomeration of manufacturing

${ }^{27}$ Mudambi (1995) stresses that a local government's participation in a location tournament (whereby it offers financial incentives to foreign firms to encourage a local establishment in the host country) is only worthwhile if the investment is "sticky" and the effects of the policy are therefore irreversible. 
activity and overall production in a geographic area as attractions for new establishments. However, particularly in the Randstad, where almost half of all Dutch firms are located, foreign firms may be discouraged by the threat of intense rivalry by local firms in the region.

When choosing between the Randstad and the rest of the Netherlands, unemployment in the region encourages new foreign establishments. This result is in line with studies by Friedman et al. (1992) and Shaver (1998). A high unemployment rate signals available labour and therefore reduces the initial and subsequent costs involved in the assembly and maintenance of a useful labour force.

The results regarding land area are contrary to our expectation that investments would be drawn to large geographic areas. Foreign firms are not attracted to regions in the north of the Netherlands where fewer people live and land therefore is less scarce. Apparently, a large number of foreign establishments is drawn to the Randstad despite the lack of available land. The small size of the Randstad area is no discouragement for new establishments. Other factors - such as available labour and infrastructure - will compensate for this disadvantage and are more important determinants of the choice for the Randstad.

We find no proof for the potential deterring effect that large property taxes may have on location choice. This result is contrary to evidence regarding taxes in studies such as Friedman et al. (1992) and Woodward (1992). However, this is not very surprising given the relatively small regional variations in this variable in the Netherlands. In addition, property taxes are only a very small percentage of the total tax burden faced by foreign and local firms. Corporate taxes are much more important but their level is determined for the entire country. Future research should test other policy variables such as subsidies to determine the effect of government policy on location choice.

It is clear that relative to European and other firms, Japanese and US firms favour the Randstad more. This result seems to suggest that firms from more distant foreign countries have a more "simplistic" location choice pattern. They favour the most obvious location: the Randstad, where the capital of the Netherlands (The Hague), three more large cities (Amsterdam, Rotterdam, and Utrecht), and large infrastructural facilities (Schiphol, Rotterdam harbours) are located. Affiliates whose parents are located in Germany and Belgium favour border-regions (Limburg and Noord Brabant for Belgium; Groningen, Drenthe, Overijssel, Gelderland, Noord Brabant, and Limburg for Germany). Low transportation costs, familiarity, knowledge of the Randstad-problems, and cultural similarity will encourage these establishments.

We find strong and significant evidence supporting the notion that relative to all other establishments, the holding companies tend to favour the Randstad area more. This result confirms earlier observations by Boeckhout et al. (1987). This choice can be explained by the need for holding offices to be close to good infrastructural facilities (including banks, office space, and telecommunications) that is readily available in the Randstad. 
Overall, the results for the binary discrete choice model are quite promising though limited because multicollinearity among the variables describing the regional characteristics limits the number of variables that can be estimated together. Unfortunately, testing the model specifications for all 12 Dutch provinces resulted in more severe problems. When including the regional dummies and when testing many regional characteristics, multicollinearity problems complicated the analyses. To solve this problem, future research should include other variables measuring the regional characteristics. However, in general, our expectation is that the inter-regional differences in the Netherlands are too small to significantly influence a firm's location behaviour. In addition, it may be true that for foreign firms inter-regional differences within the Dutch borders do not matter anyway. Instead, they may consider the Netherlands to be just one of many interesting regions within the European Union (EU). The Single Market Program has clearly stimulated the mobility of capital due to the removal of barriers to FDI. Foreign firms may therefore look for the European location that best fits their purpose, comparing the Randstad with the Ruhr-area in Germany, Lille in France, or Manchester in the UK. One promising extension of this study could therefore be a similar analysis for all European countries or specific regions. However, the data requirements for such a comprehensive analysis are beyond the scope of this current study.

\subsection{Conclusion}

In this chapter we estimated a location choice model using establishment data on all new foreign establishments in the Netherlands between 1992-1996 and 1995-1996. We find that new foreign ventures do not simply mimic the geographical pattern of Dutch establishments in general. Instead, initial investments by foreign firms spur subsequent investments from foreign firms in the same region. As a result, foreign establishments tend to be concentrated in agglomerations in the Randstad-area.

So far, the analyses presented in Chapters 3 and 4 have considered both the macroeconomic and regional determinants of foreign investments. However, they do not take the motivation of individual firms into consideration. To find out which locational factors have determined the choice of an MNE for the Netherlands, a questionnaire survey was conducted. The results of this study are discussed in Chapter five. 


\section{Chapter five}

\section{DETERMINANTS OF FDI ACTIVITY IN THE DUTCH ELECTRONICS INDUSTRY}

\subsection{Introduction}

For more than two decades, the eclectic paradigm has remained the dominant analytical tool for accommodating a variety of operationally testable economic theories of the determinants of foreign direct investment (FDI) and the foreign activities of multinational enterprises (MNEs) (Dunning 2000). The paradigm states that the extent, geography, and industrial composition of foreign production undertaken by MNEs are determined by the interaction of three sets of interdependent variables: ownership, location, and internalisation advantages ${ }^{1}$.

Ownership (O) advantages are factors unique to the nature or nationality of the ownership of a firm and are referred to as the "why" of multinational activity (Dunning 1988). They relate to the multinational's ability to compete in foreign markets and are based on unique country-, industry-, and firm-specific variables. MNEs try to use their $\mathrm{O}$ advantages in conjunction with the immobile natural and created assets that are location- and countryspecific (Narula and Dunning 2000). These location (L) advantages affect the choice of a specific foreign country for multinational operations and are referred to as the "where" of international production (Dunning 1988). Internalisation (I) advantages determine whether the firm will organise its international transactions efficiently through markets or through internal (hierarchical) means and address the "how" of involvement (Dunning 1988).

Dunning's eclectic paradigm offers a broad framework to study MNEs' foreign production activities. It has most frequently been tested with respect to the MNE's choice of entry mode. Important examples include Agarwal and Ramaswami (1992), Brouthers et al. (1996, 1999), Dunning and Kundu (1995), Tatoglu and Glaister (1998a), and Tse et al. (1997). Furthermore, many studies have analysed one particular aspect of the eclectic paradigm, either the O, L, or I advantages (for a thorough overview see Dunning 1993). Only a few studies have empirically tested the combined influence of all three determinants of the OLI-paradigm on the decision to locate an affiliate in a specific host country. Important attempts include the study of Tatoglu and Glaister (1998a) who

\footnotetext{
1 The eclectic paradigm is therefore also known as the OLI paradigm. However, given the sequential nature of the three groups of advantages (Williams 1997), perhaps OIL would have been a better abbreviation. In this study, we stick to the known abbreviation but will discuss the advantages in the OIL sequence.
} 
analyse FDI in Turkey ${ }^{2}$, Chandprapalert (2000) who explores the OLI determinants of US firms located in Thailand ${ }^{3}$ and O'Gorman and McTiernan (2000) who analyse the applicability of the Eclectic Paradigm for the internationalisation of small and mediumsized Irish Hotels ${ }^{4}$.

A comparable study for the Netherlands is missing. It is generally believed that the favourable location at the North Sea and the quick and easy access to the most important European markets are important locational determinants of FDI inflows in the Netherlands. These factors are further enhanced by good infrastructural facilities such as Schiphol Airport and the Rotterdam harbours, and the highly skilled, multi-lingual labour force (Ernst and Young 1996, CBIN 1996, 1997, Buck 1989, KPMG 1996a, 1996b, 1998). However, the influence of these location characteristics has not been tested scientifically.

This chapter attempts to fill this gap by analysing the OLI determinants of Dutch inward FDI for a group of 86 foreign affiliates in the electronics industry. Their CEOs were contacted using a mail questionnaire in fall and winter 1999. With the quesionnaire, we aim to answer three broad research questions that relate to the three groups of factors of the OLI paradigm:

\section{Which ownership advantages do foreign firms that invest in the Dutch electronics sector possess?}

\footnotetext{
${ }^{2}$ Tatoglu and Glaister (1998) consider the motives and characteristics of 98 western MNEs' foreign direct investment in Turkey. They find that the relative importance of the OLI factors varies most with the sector of the investment (industry or services), to a moderate extent with the size of the investment (small to medium or large) and to a moderate extent with the ownership pattern of the investment (wholly owned subsidiary or joint venture). Tatoglu and Glaister use factor analysis to reduce 38 items to 10 factors that are labelled O ( 2 factors: production \& resource efficiency and firm-specific advantages), L (six factors: market potential, host government policies, investment risk, strategic locational advantages, labour supply \& infrastructure, and industry competition), or I ( 2 factors: transaction-specific costs and quality control). The Cronbach alphas for each factor range from 0.61 to 0.89 .

${ }^{3}$ Chandprapalert (2000) survey of 100 US firms located in Thailand considers FDI to be the result of ownership advantages (measured as firm size and firm's multinational experience), location advantages (measured as market potential and host government policy), internationalisation (measured as investment risk) and strategic motivation (resource-seeking or marketing-seeking investments). It should be noted that Chandprapalert mistakenly considers internationalisation as part of the OLI paradigm. This should be internalisation. The results (that are not presented in the text) show that firm size $(+)$, market potential $(+)$, and investment risk (-) as factors affecting U.S. investment in Thailand. US investors turn out to be both market-seeking and resource-seeking.

${ }^{4}$ O'Gorman and McTiernan (2000) use a structured questionnaire to study 16 Irish hotel groups that were internationalising or planning to do so in the near future. The most important ownership advantages influencing the internationalisation of Irish hotels were their knowledge of prospective customers' tastes and the quality of their services in the domestic market. The most important locational factors are psychic and physical proximity to the host country and the market potential of the host country. The hotels chose to internalise the activity within the group to assure quality control and improve co-ordination. Overall, they find that SMEs (particularly hotels) seeking international success must develop both an ownership advantage that will transfer to foreign markets, and the organisational capacity necessary to support an internationalisation strategy.
} 
2. Why did these foreign electronics firms choose to internalise their Dutch activities within the firm?

3. What are the most important locational determinants of inward FDI in the Dutch electronics sector?

We first present a theoretical framework for the analysis of the determinants of inward FDI within the eclectic paradigm in Section 5.2. Section 5.3 then discusses the hypotheses derived from this framework for the foreign electronics firms that have establishments in the Netherlands. Section 5.4 gives a description of the questionnaire, followed by a discussion of the data in Section 5.5. Section 5.6 presents the results of the questionnaire study. A discussion of these results is given in Section 5.7. Section 5.8 presents the conclusions.

\subsection{Theoretical foundations of the OLI paradigm}

The eclectic paradigm of international production (Dunning 1980, 1988a, 1995, 2000, 2001) currently is the most widely accepted theoretical framework to analyse foreign production by multinational enterprises. The eclectic paradigm seeks to offer a general conceptual framework for determining both the extent and pattern of foreign-owned production resulting from outward FDI undertaken by a country's own enterprises and that of domestic production owned by foreign enterprises as a result of inward FDI (Dunning 1993). The popularity of the eclectic paradigm of international production can easily be explained by the straightforward manner in which it classifies the many important factors that influence international production (Hoesel 1997) ${ }^{5}$. The content and predictions of the eclectic paradigm are firmly embedded in a number of different economic and business theories. Although taken separately, none of these theories offer a comprehensive explanation of the growth and decline of MNE business activity, taken together - i.e. as a group - they do so (Dunning 2000). Dunning (1993) presents a large list of variables that is culled from a variety of sources. We have chosen to group related variables to enhance the understanding and interpretability of the framework ${ }^{6}$. A graphical model of the OLI determinants and the variables these determinants are composed of is presented in Figure 5.1. The three groups of advantages are sequential. First an ownership advantage must be present before market failure leads to

\footnotetext{
${ }^{5}$ However, some limitations to the OLI paradigm exist as well. It is strongly biased towards international production and does not explain other modes of international business (such as strategic alliances) as thoroughly. Furthermore, the paradigm is rather static and does not take into account that the OLI configuration can change over time.

${ }^{6}$ Dunning (1993) has grouped the ownership-specific advantages to intangible asset advantages (Oa) and transaction variables (Ot). For the internalisation advantages, we have decided to separate the cost from the control issues. Different modes of FDI involve different costs and result in different levels of control over the foreign activities. Any MNE has to weigh these two aspects when deciding on a foreign entry. For location we distinguish seven broad groups that together can explain the attractiveness of a host location to foreign investors.
} 
internalisation. Following internalisation, location factors will dictate the site of the investment (Williams 1997). In the following section, we will discuss all three groups of determinants and their theoretical foundations.

\subsubsection{Ownership advantages}

Several strands of economic and business theory assert that the ability and willingness of firms to become MNEs depends on the possession of some kind of unique and sustainable competitive advantage (or set of advantages) that is specific to the ownership of the investing enterprise. These firm-specific ownership (O) advantages make it possible to overcome the disadvantages associated with carrying out business activities in foreign markets, the "liability of foreignness" (Buckley and Casson 1976, Dunning 1988b, Hymer 1960). Foreign producers are less informed about local business practices, regulations, and consumer preferences than indigenous firms. MNEs therefore need a competitive edge over their indigenous competitors if they want to operate successfully in a foreign market.

The significance and nature of $\mathrm{O}$ advantages is country-, industry-, and firm-specific ${ }^{7}$. In general, Dunning (2000) identifies three main kinds of ownership advantages:

1. Those relating to the possession and exploitation of monopoly power as initially identified by Hymer (1960, published 1976) and industrial organisation scholars (Caves 1971, 1996, Porter 1980, 1985). These advantages are presumed to stem from, or create, some kind of barrier to entry and/or mobility in final product markets.

2. Those relating to the possession of a bundle of scarce, unique, and sustainable assets, resources, and capabilities, which reflect the technical efficiency of a particular firm relative to its competitors. These advantages stem from or create barriers to entry and/or mobility in factor and intermediate product markets.

3. Those relating to the competencies of managers to identify, evaluate, and harness resources and capabilities throughout the world, and to coordinate these with the existing resources and capabilities under their jurisdiction in a way that is in the best long term interest of the firm. These advantages are stressed by organisation scholars such as Bartlett and Ghoshal (1989), Prahalad and Doz (1987), Guisinger (2001) and Madhok and Phene (2001).

\footnotetext{
In producer goods industries, the $\mathrm{O}$ advantages can result from the nature and quality of the products supplied, from the firm's ability to produce at lower cost, or from the ability to take advantage of the economies of (large) scale in production. In consumer goods industries, the possession of brands and trademarks together with the ability to offer and market a reliable product customised to the needs of the local market can give a firm a competitive edge over its competitors (Dunning 1993). In services, national "champions" with a well-established name and reputation may find it lucrative to convert their existing good will and image into money in other countries. Furthermore, managerial and/or organisational superiority (such as knowledge of back office procedures, service quality, shelf space allocation, and customer friendliness procedures) may be applied in foreign markets as well (Kasper et al. 1999)
} 


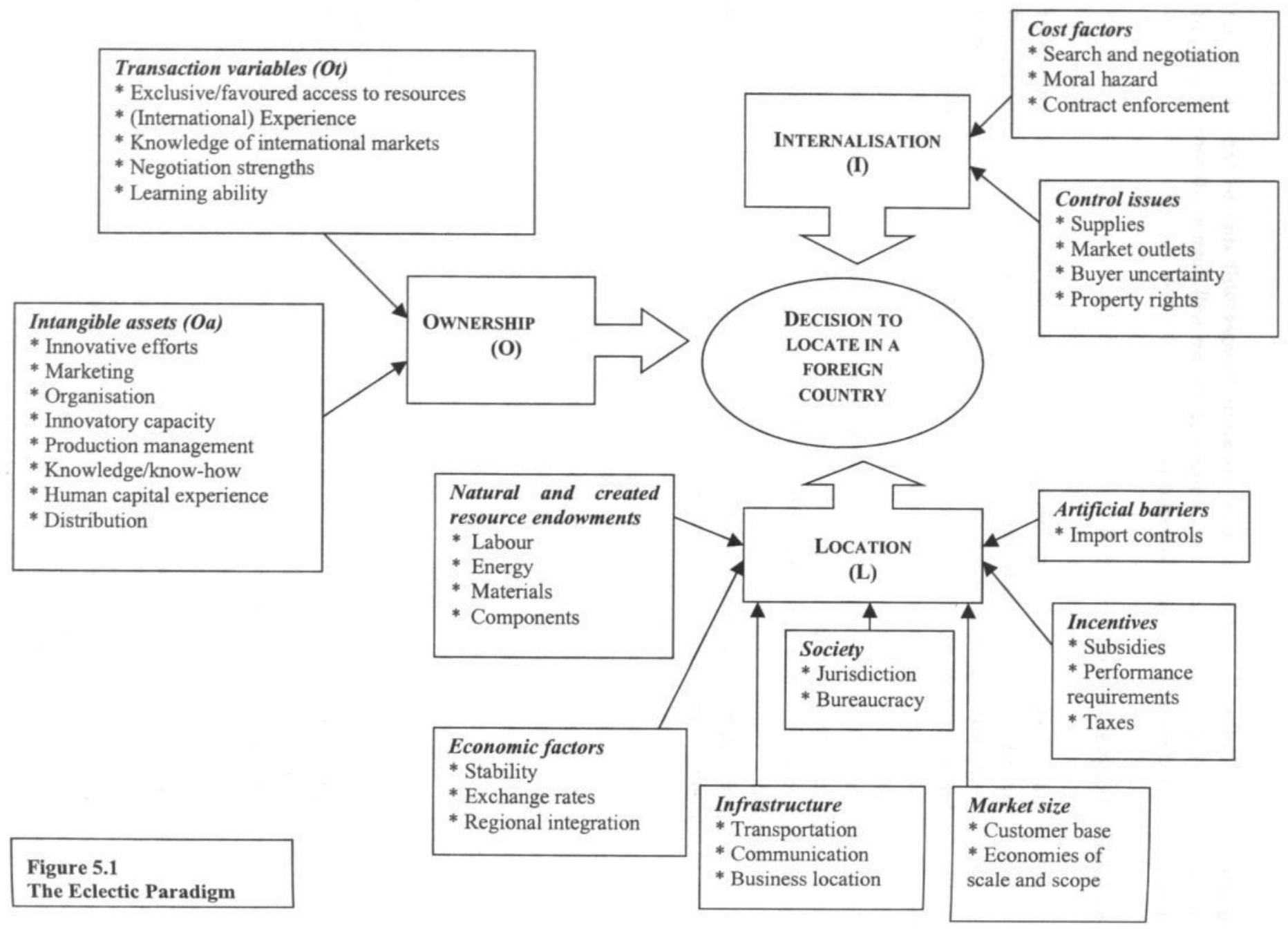


The first two groups relate to property rights and the possession of particular intangible assets and are frequently classified as asset (Oa) advantages. They include innovative efforts, production management, organisational and marketing systems, and noncodifiable knowledge.

These advantages have to be distinguished from the ability of the firm to coordinate multiple and geographically dispersed value-added activities. The latter are frequently referred to as transaction cost minimising (Ot) advantages. The third group of variables relates to this ability. It arises from experience and because of multinationality ${ }^{8}$ per se. These Ot advantages may result from economies of scope in production, exclusive or favoured access to inputs, better access to or knowledge of foreign markets, or the learning ability and experiences of the firm. Both groups and their components are shown in Figure 5.1.

\subsubsection{Internalisation advantages}

Assuming that an $\mathrm{MNE}$ has a unique $\mathrm{O}$ advantage, the firm has to decide whether to sell this advantage (or the right to its use) to foreign firms or to internalise the exploitation of the advantage within the hierarchy of the firm. Orthodox internalisation theory states that as long as the transaction and coordination costs of using external arm's length markets in the exchange of intermediate goods, information, technology, marketing techniques, etc. exceed those incurred by internal hierarchies, it will pay a firm to engage in FDI rather than conclude a licensing or another market-related agreement with a foreign producer (Hennart 1982, Dunning 2000). Internalisation (I) advantages therefore are the perceived advantages of hierarchical control. They are related to the costs of choosing a hierarchical mode of operation over an external one. Figure 5.1 indicates the cost and control issues related to internalisation.

The internalisation of international operations comes at a cost because in general it is more difficult for and demanding on management to control many and highly dispersed activities than a few localised activities. These costs must be compared to the costs of finding, maintaining, and enforcing an external relationship to perform the same function in the international market. External markets can be characterised by bounded rationality, opportunism, adverse selection, moral hazard, and information impactness (Teece 1981, Williamson 1985). A licensee may therefore become a competitor and a sales agent or component supplier may not provide high quality products or services. The MNE thus risks loosing its unique strength when engaging in cross-border transactions through markets.

The costs and risks involved in external markets may therefore encourage the MNE to coordinate different stages of the value-added chain under the same governance (Dunning

\footnotetext{
${ }^{8}$ Recently, several authors have drawn attention to the fact that the international expansion of a firm's operations itself can contribute to the generation of new $\mathrm{O}$ advantages, for instance in dispersed subsidiaries or R\&D laboratories (Pearce 2001).
} 
1993). It can forward integrate into cross-border sales and distribution ventures if the MNE perceives the need to gain control of selling outlets to ensure that the product exported is efficiently marketed and a proper standard of after-sales services is maintained. An MNE can also choose to backward integrate the supply of intermediate goods and raw materials. By internalising intermediate production processes the MNE reduces uncertainty about quality and timely delivery of supplies and circumvents market imperfections (Buckley and Casson 1976). Internalising these markets may actually result in additional Oa and Ot advantages for the firm (Buckley and Casson 1976, Hennart 1982, Hennart 1989, Rugman 1982). If, for example, an MNE internalises a raw material market in order to prevent competitors from getting access to a critical primary product, its exclusive access to this raw material gives it a unique position in the market. The same is true for the internalisation of a unique product or process technology.

\subsubsection{Locational advantages}

Obviously, MNEs will try to match, augment, or exploit their $\mathrm{O}$ advantages in combination with the immobile natural or created endowments in a host location. Only recently have scholars shown renewed interest in the investigation of the importance of locational choices of MNEs (Froot and Stein 1991, Krugman 1991, Porter 1996, Venables 1998). Older contributions include the locational component of Vernon's product cycle theory (Vernon 1966), Knickerbocker's "follow my leader" theory (Knickerbocker 1973), and Rugman's risk diversification theory (Rugman 1979).

The locational attractions (L-advantages) of alternative countries are area-specific and depend on the type of investment undertaken. They include both market potential and market risk factors (Root 1987). Measures of location advantages that pull investment towards a foreign location are numerous. As illustrated in Figure 5.1, we broadly distinguish seven groups of variables. First of all, foreign investors are attracted to locations with large (potential) demand, particularly if their investment is market-seeking in nature. Furthermore, inward investment can be facilitated and encouraged by the overall economic, legal, political, and trade policies. Obviously, investors favour countries with economic and political stability. Furthermore, they sometimes try to circumvent trade barriers by local production in a host market. FDI is also attracted to regions with good infrastructure provisions, particularly if the investment is efficiencyseeking. The MNE then tries to benefit from the concentration of production in a limited number of locations that supply multiple markets. The ease in reaching those markets is then extremely important. The overall attractiveness of a host location is further enhanced by government incentives and subsidies. If the investment is motivated by resourceseeking arguments, the local availability of natural and created resources (such as unskilled or skilled labour, energy, and raw materials) is of determining importance. Investors will favour areas where resources are cheap, affluently available, and of high quality (Dunning 1993). Strategic asset-seeking firms favour host markets that allow 
them to acquire assets that will strengthen their long-term competitiveness. Strategic assets seekers therefore choose locations where the acquisition of a competitor or supplier opens up new markets, lowers transaction costs, creates synergies, or results in greater market power.

\subsection{Hypotheses}

One of the important criticisms of the OLI paradigm is that the explanatory variables identified are so numerous that its predictive value is almost zero. However, the paradigm intends to point out a generic set of variables that contains all ingredients necessary for any satisfactory explanation of particular types of international value-added activity. This framework can be adapted for specific activities and specific countries ${ }^{9}$, significantly reducing the number of variables under consideration. As indicated in Chapter one, we focus our attention on the foreign business activities in the Dutch electronics industry. Dunning (1993) suggests that foreign investments in that industry are mainly marketseeking and efficiency-seeking in nature. We can therefore analyse specific variables related to these kinds of investments ${ }^{10}$. Based on the model presented in Figure 5.1, where we distinguished 11 groups of variables influencing the investment decision of a multinational enterprise to locate an affiliate in a specific host market, this section introduces a hypothesis for each of those groups of variables.

\subsubsection{Ownership advantages}

For any firm to engage in FDI, it is necessary to have a unique characteristic (either a resource or a capability) that allows the firm to successfully compete in a market that is foreign. This unique characteristic results in a competitive advantage for the MNE and gives the firm a particular strength in the market. Very few studies have analysed the competitive strengths of MNEs. One important exception is Forsgren et al. (1999). They find that the strength of a subsidiary is mainly based on the unique internal capabilities of the firm such as the level of product development, available technological expertise, and the knowledge off the professional staff.

As discussed in Section 5.2, we can broadly distinguish two groups of $\mathrm{O}$ advantages, $\mathrm{Oa}$ and Ot. Oa advantages are related to the actual product an MNE produces. This product can be based on a unique technology or cover a niche in the market where no real competitors exist. It can be tailored to a specific product market or be competitively

\footnotetext{
${ }^{9}$ Not all the identified locational advantages are applicable in all host countries. In Austria, for instance, a sea harbour is never a determining factor due to the geographic location of the country.

${ }^{10}$ Considering that only so few studies exist that have tried to empirically test the OLI paradigm, we decided to use general formulations of the hypotheses. That way, the hypotheses can be used in other studies (looking at different industries or host markets) again and will it be possible to compare the results of these studies with the present study on foreign electronics affiliates in the Netherlands.
} 
priced. It can also be produced at a profitable cost due to economies of scale in production. Furthermore, the $\mathrm{Oa}$ advantages can be related to unique organisational capabilities such as marketing skills and the efficient use of good distribution channels that help to position the product visibly in the market. All these characteristics may give the MNE a competitive strength that allows it to compete in a foreign market. We therefore hypothesise:

H1: Asset-related ownership advantages (Oa) will positively influence a foreign firm's decision to start activities in a host economy

A firm can also derive a unique position in a market from its ability to organise international activities within the firm. Again these Ot advantages can be directly related to production or more to the organisation of activities and the skills of people. If a firm manages to establish good contacts and a long-term mutually beneficial relationship with its suppliers, it can develop a competitive edge over its competitors. When the MNE can obtain higher quality supplies more quickly and at lower prices, this is a competitive advantage in itself (Dunning 1993). Furthermore, economies of scope and specialisation can result in a stronger position in the international market. These production-related strengths are further enhanced by the MNE's knowledge of and experience in operating in foreign countries. We therefore suggest the following hypothesis:

H2: Transaction-specific ownership advantages (Ot) will positively influence a foreign firm's decision to start activities in a host economy.

\subsubsection{Internalisation advantages}

MNEs can choose to leave their international transactions to the market or to internalise them within the firm. If the MNE does not internalise the exploitation of its competitive strength within the firm (i.e. entering the host market with a greenfield wholly-owned subsidiary, WOS) several other modes exist. The alternatives to WOS include exports to the Netherlands, either directly or by use of an agent, and licensing of the technology to a Dutch or European firm. In general, these forms involve less money and a smaller (resource) commitment to the host market and allow the MNE a gradual introduction to the host economy. However, they also offer less control over the conducted activity.

Foreign production by a WOS may be preferred over licensing if no suitable licensee exists, or because the MNE fears that a licensee may become a competitor (Dunning, 1993). Furthermore, it is difficult to guard the quality of a product once its production has been licensed to a (foreign) firm, which involves risks for the reputation of the licensor. 
In addition, it may be difficult to convince a potential buyer of the characteristics and quality of an input without revealing too much of its unique technology ${ }^{11}$.

Using an agent permits a gradual market entry at low financial exposure. It allows the MNE to acquire knowledge about the foreign market and to fine-tune the products offered to the consumers' taste in the host market. However, the MNE is then vulnerable to trade restrictions and potential conflicts with distributors.

An MNE may also choose to internalise the activities of a competitor, supplier, or buyer within the firm if a good acquisition opportunity arises. Since the acquired firm already has a customer base, it is less demanding on management to operate an acquisition than a greenfield establishment. As we expect that MNEs will try to minimise their exposure when entering an unknown host market, we hypothesise that MNEs only establish greenfield establishments if other alternatives are unavailable:

H3: The unavailability of alternative modes - such as acquisition, licensing, or sales via an agent - positively influences the foreign firm's choice to start an affiliate in a host market.

Choosing another mode than a wholly-owned subsidiary to serve foreign markets involves risks and costs. Particularly important are the costs related to negotiating, monitoring, and enforcing contracts with partners. This is a both costly and timeconsuming activity. Furthermore, there are high costs related to litigation. These costs can motivate the MNE to internalise the transactions within the hierarchy of the firm. We therefore suggest the following hypothesis:

H4: High costs of making and enforcing contracts negatively influence a foreign firm's decision to start activities in a host economy.

\subsubsection{Locational advantages}

As shown in Section 5.2, we broadly distinguish seven groups of locational determinants attracting FDI: market size, infrastructure, natural and created resources, economic factors, societal provisions, artificial barriers, and incentives. Although these are general factors that could be applied to any country, hypotheses five to eleven discuss the attractiveness of these groups of variables specifically for inward FDI in the Netherlands. Many researchers have posited that the size and rate of growth of the host country market can be a critical determinant of inward FDI flows. If a host market is sufficiently large to provide a customer base that allows profitable foreign operations, MNEs may consider starting a local affiliate in that host market. In addition, a move abroad may allow a

"Several empirical studies have evaluated the determinants of the licensing versus FDI decision. Particularly noteworthy are studies by Contractor (1984), Davidson and McFetridge (1985), Kogut and Singh (1988) and Kumar (1990). 
diversification of the MNEs activities. Furthermore, being close to the customer facilitates after-sales services and monitoring of changing customer preferences. Perhaps a client even insists on a local support affiliate. These consumers and clients should be understood to include both individuals and firms that buy components. The size and characteristics of a host country market therefore act as a pull factor on inward FDI. Likewise, a foreign firm can get pushed out of his own home market if that market is saturated. In addition, the foreign firm can follow important competitors fearing that if it does not, (potential) customers will choose the competitor as their supplier. In case of the Netherlands, the host market is relatively small. Only 15.7 million potential customers inhabit a relatively small geographic area. However, the country is strategically located within the Benelux and the European Union. An extensive infrastructure network allows foreign firms to quickly reach over 300 million European citizens. It is very likely that the attractiveness of the Dutch market therefore stretches beyond the Dutch borders and includes the entire European continent. We therefore hypothesise:

H5: The location of a host market within a larger regional market positively influences a foreign firm's decision to start activities in a host economy.

It is generally believed that the locational attractiveness of a country is partly dependent on the infrastructural provisions in that country. We can broadly distinguish three elements to infrastructure: transportation, communication, and business location. For the Netherlands we see that the transportation system is quick, safe, and cost effective. The Netherlands is home to Schiphol Airport, one of the top four airports in Europe ${ }^{12}$, with 460,000 takeoffs and landings and over 45 million terminal passengers each year. Schiphol is within three hours' flight time from all European capitals and over 240 destinations all over the world can be reached from the airport. Just $70 \mathrm{~km}$ south of the airport, the Port of Rotterdam is located, the largest world port in terms of tonnage handled (323.4 million tons in 2000). The Port facilitates the transportation of many goods via an extensive infrastructure that includes water, road, rail, and pipeline connections. Strategically located at the delta of the Rhine and the Meuse in the North Sea, the Port offers outstanding water links to Europe, North America, and Asia. These connections are further enhanced by the Port of Amsterdam (annually handling over 63 million tons of goods) and the Zeeland Seaports at the Western Schelde river (handling over 50 million tons of cargo each year) (NFIA 2001). The cargo handled at the harbours is transported all over Europe by road and rail. The density of the road network in the Netherlands amounts to $4,0 \mathrm{~km}$ per $\mathrm{km}^{2}$, closely following Belgium and Singapore that

${ }^{12}$ Closely following London Heathrow, Frankfurt, and Charles de Gaulle, Paris for both passenger and freight transportation (Schiphol Annual Report 2001). Aside from Schiphol, the Netherlands has several other airports located near Rotterdam, Eindhoven, Maastricht, and Eelde near Groningen. 
have the world's highest road densities (IMD 1999) ${ }^{13}$. Regarding railroad density, the Netherlands ranks seventh worldwide, with $0.076 \mathrm{~km}$ of rail per $\mathrm{km}^{2}$ (IMD 1999). Huge investments are made in the Betuwe-route project that should provide a future backbone of European freight transportation. The Betuwe-route is a double track freight railway linking the Port of Rotterdam directly to the European hinterland. This railway should strengthen the position of the Netherlands as a distribution and transport country, without excessive environmental impact.

Regarding the communication infrastructure, we expect firms to favour locations where the spread and availability of information technology and communication resources is high. This is particularly important for services firms that strongly depend on communication to reach their clients. With 340 computers for every 1000 inhabitants, the Netherlands ranks twelfth (following the US, the Scandinavian countries, Australia, Canada, New Zealand, and Singapore) when considering the technological infrastructure (IMD 1999). The number of Internet hosts amounts to 34.58 per 1000 people and the number of main telephone lines amounts to 584.5 per 1000 inhabitants, putting the Netherlands in the ninth position worldwide for both factors (IMD 1999).

A final infrastructural aspect concerns the availability and price of business locations such as office space, warehousing facilities, and industrial parks. In the international arena, the Netherlands does not perform so well in this aspect (Ministry of Economic Affairs 1999). The Dutch government makes a strong effort to provide high quality business locations. It monitors the future supply and demand of business locations but leaves the actual planning to local and provincial authorities. However, strict land regulations result in lengthy decision-making procedures regarding industrial estates resulting in slow development of additional space (Schuur 1999). Overall, office space is reasonably priced (US\$ 389 per $\mathrm{m}^{2}$ per year), considerably cheaper than in Switzerland, Ireland, Germany, Sweden, France, and the UK, but more expensive than in its direct neighbour Belgium (IMD 1999). From this discussion it is clear that the infrastructural provisions in the Netherlands are highly developed and offer excellent connections to the European continent. We therefore suggest the following hypothesis:

H6: Large infrastructural provisions positively influence a foreign firm's decision to start activities in a host economy.

The choice for a foreign location is also positively influenced by the availability, quality, and price of both natural and created resources. These resources broadly include raw materials, components, energy, and unskilled or skilled labour. Foreign firms try to acquire those resources at a lower price than can be obtained at home. In addition, MNEs also try to gain privileged access to resources vis-à-vis their competitors.

\footnotetext{
${ }^{13}$ However, despite the density of roads, traffic congestion is a considerable problem that the governments is trying hard to solve.
} 
For the Netherlands, Chapter two has illustrated that the most important natural resource is fertile soil. Furthermore, both gas and petroleum are found there, but local Dutch firms dominate their exploitation ${ }^{14}$. In general, created assets are therefore much more important as locational attractions in the Netherlands than natural resources are. One of the frequently mentioned strengths of the Dutch economy is the quality of the labour force (Ministry of Economic Affairs 1999). Higher education enrolment amounts to 10.7 percent of all persons aged 17-34 (IMD 1999). Annually more than 375,000 students attend university and higher vocational training (NFIA 2001a). Extensive language training results in multi-lingual labourers that are attractive employees in internationally oriented firms (KPMG 1996a, 1998, NFIA 2001a). The Dutch educational system provides industry and research with a constant inflow of well-trained, highly motivated talent. The total labour force amounts to 6.87 million people, equalling 43.8 percent of total population (IMD 1999). Dutch management usually has significant experience in operating in international markets (only managers from Luxembourg have more experience) and senior managers are sufficiently available (IMD 1999). Overall labour productivity is high, amounting to US\$ 49,217 per person employed in 1998 (IMD 1999). The Netherlands closely follows Belgium, the US, Italy, Ireland, Israel, Germany, and Austria. Dutch productivity growth is only outpaced by Ireland and Israel and a number of newly industrialising or developing countries (Philippines, Mexico, Venezuela) (IMD 1999). In addition, skilled foreign managers and specialised staff can be employed in the Netherlands. Work and residence permits are normally issued to these employees, provided that they have complied with entry requirements (Ernst and Young 1996). EU members can work without permits. Only few industrial disputes occur, with an average of 15 working days lost per 1000 people for the last 3 years (IMD 1999). However, Dutch labour regulations (regarding hiring and firing personnel and minimum wages) generally are seen as too restrictive and the unemployment legislation provides little incentive to look for work (IMD 1999).

Besides raw materials and labour, the access to knowledge is a third aspect of resource availability. Many well-known research institutes are located in the Netherlands. Among them are TNO (the Netherlands' Organisation for Applied Scientific Research, active in fields ranging from nutrition to industrial technology), the Delft International Institute of Hydraulic Engineering, the RIVM (National Institute of Public Health and Environmental Protection), and ECN (Netherlands' Energy Research Centre). Furthermore, 13 universities exist, among which three technical universities in Delft, Eindhoven, and Twente. The desire to cooperate with these institutes to tap into the knowledge created there may motivate foreign firms to establish affiliates in their proximity.

Finally, foreign firms may also be motivated by the need to be close to their suppliers, to secure the timely availability of their components. In addition, they may also want to be near key industry markets, to benefit from agglomeration economies. As was discussed in

${ }^{14}$ Both natural resources are not important for electronics firms which are studied here. 
Chapter four, agglomeration can result in a pool of specialised labour, facilitates the development of specialised inputs and services, and enables firms to benefit from knowledge spillovers. If their foreign suppliers and competitors are located in the Netherlands, other firms may consider locating an affiliate there as well.

We suggest the following hypothesis.

H7: Resource availability positively influences a foreign firm's decision to start activities in a host economy.

FDI inflows may also be encouraged by a favourable overall economic climate and deterred by symptoms of economic vulnerability. Schneider and Frey (1985), for instance, find that both balance of payment deficits and the rate of domestic inflation were negatively and significantly related to inbound FDI. Several studies pinpoint to the Netherlands as one of the most attractive locations for doing business. The Netherlands ranks first on the list of the Economist Intelligence Unit (august 2001), fifth on IMD's 2000 ranking, and fourth when classified by the World Economic Forum (2000). The overall credit rating (as indicated by institutional investor magazine) is high, with the Netherlands in third position in 1998, following Switzerland and Germany.

Chapter two has already illustrated the remarkable economic recovery the Dutch economy has experienced during the last two decades. The Dutch "Polder"-model allowed a move away from the "Dutch Disease" (a stagflating economy in the early 1980s) towards the "Dutch Miracle" characterised by strong economic growth, employment expansion, and a relatively small budget deficit. This strong economic development makes the Netherlands an attractive investment location in the 1990s.

Furthermore, the status of foreign firms is generally the same as that of purely Dutch enterprises. The Central Bank (DNB) allows foreign firms to borrow in the Dutch market and the stock market is among the best in the world (IMD 1999). Therefore capital is easily available for foreign firms (IMD 1999). The cost of capital does not hinder a competitive business environment in the Netherlands. The country ranks second in the opinion of managers, following Switzerland (IMD 1999). Furthermore, foreign firms can benefit from the virtual absence of exchange controls in the Netherlands and no restrictions are imposed on the repatriation of earnings, capital, royalties, or loan interest (Ernst and Young 1996).

The Dutch guilder is a relatively stable currency, partly due to its peg with the German Mark. The Netherlands qualified for all the European Monetary Union (EMU) conditions and was therefore among the countries introducing the euro as a common European currency in 1999. Chapter two already illustrated that the Netherlands was among the initiators of European integration. Inflation is slightly higher than in most European countries (increasing to 5.4 percent annually in 2001 (Walschots 2001)). However, the overall economic climate is stable and the business environment is conductive for foreign investment. We therefore hypothesise: 
H8: A stable economic climate positively influences a foreign firm's decision to start activities in a host economy.

Foreign firms may be encouraged to choose a specific location if the host country government is prepared to provide some financial incentive, such as a subsidy or tax deduction. Host country policies are therefore frequently mentioned as important determinants of inward FDI. The Dutch government opposes "buying" foreign firms, although it admits to sometimes "matching" the offers of other countries' regional investment agencies (Ministry of Economic Affairs 1999). In principle, the same possibilities exist for both local and foreign firms. All firms can apply for generic subsidies that stimulate $\mathrm{R} \& \mathrm{D}^{15}$, energy-saving, and environmental protection. Furthermore, a system of discretionary depreciation is available for investments in certain assets that cause less environment pollution and for investments in energy-saving assets. Wage tax reductions for R\&D salaries exist. Dutch tax law does not contain specific rules on (inter-company) transfer pricing. The Netherlands has bilateral tax treaties with over fifty countries on the relief from double taxation and reducing withholding taxes on dividends, interests, and royalties (NFIA 1997). Furthermore, written tax agreements can be got from tax inspectors to allow international tax planning up to ten years in advance. We therefore expect that:

H9: Government incentives positively influence a foreign firm's decision to start activities in a host economy.

Inward FDI is also encouraged by a sufficient legal system. The legal system in the Netherlands is based on civil law. As a member of the EU, the Netherlands is subject to many EU regulations and directives that frequently overrule national law. This is particularly visible in the anti-trust regulations.

FDI is facilitated by efficient bureaucracy. The Netherlands Foreign Investment Agency (NFIA) provides a one stop shop for international investors. MNEs can get all necessary information on doing business in the Netherlands in one go. Furthermore, Dutchregistered companies may be formed by foreigners without difficulty (Ernst and Young 1996). In addition, any company formed under the laws of another country may freely operate in the Netherlands (Ernst and Young 1996). We therefore expect that:

H10: Adequate societal provisions positively influence a foreign firm's decision to start activities in a host economy.

Sometimes FDI is motivated by the need to avoid trade barriers. If it is impossible for a firm to supply a foreign market by exports from the home country due to quota, tariff

15 Such as the PBTS (programmatische bedrijfsgerichte technologie-stimulering) for projects in biotechnology, environmental technology, and equipment technology. 
barriers, or excessive import controls, a firm may decide to set up a local establishment to serve a host market. The European integration process has fuelled the fear of trade restrictions particularly among firms outside the EU. These firms were encouraged to start local affiliates to protect their existing markets.

Overall the trade regime in the Netherlands is very liberal. Generally, neither import nor export licences are required in the Netherlands (KPMG 1996b). A few exceptions regarding the imports of textiles, steel products, firearms and ammunition, exotic animals and plants, and certain chemicals (that all require licenses) exist. Dutch exports enjoy the most-favoured nation rate in every country (KPMG 1996b). Currency transactions related to imports and exports do not require a special license (Ernst and Young 1996). The efficiency of Dutch customs encourages inward FDI. Once customs authorities have approved and licensed the internal procedures of companies, the country's E-type bonded warehouse system allows companies to move goods without additional paperwork. Only subject to spot-checks, they achieve full freedom in their logistic operation (NFIA, 1997). We therefore hypothesise:

\section{H11: Existing trade regulations and efficient customs positively influence a foreign firm's decision to start activities in a host economy.}

Figure 5.2 summarises the hypotheses presented in this section.

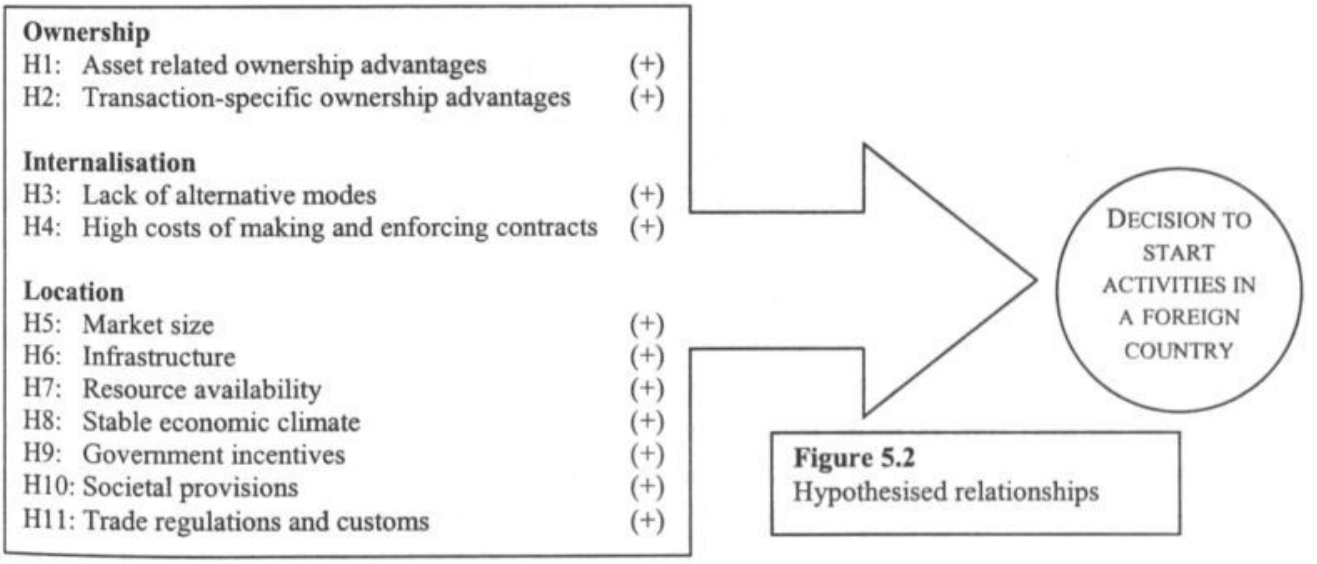

\subsection{Methodology}

The data used to test these hypotheses are the result of a mail survey of all foreign establishments in the Dutch electronics industry ${ }^{16}$. We chose a survey because the firms

\footnotetext{
${ }^{16}$ For a description of the electronics industry included in the sample see Appendix C, section 3 .
} 
investigated for this study were too many and too widely dispersed to contact all of them for interviews. A survey is an impartial and systematic means of getting information from a relatively large group of firms, without being too demanding on time and money. It was therefore an appropriate tool for our purpose. A full description of the survey methodology is given in Appendix C. The actual survey is presented in Appendix B. The questionnaire consisted of three groups of questions ${ }^{17}$. First of all, facts were asked. How long had the affiliate been in the Netherlands, where is its parent located, does the parent have other affiliates in the Netherlands or Europe, what is the affiliates most important activity? Secondly, we asked the CEO's opinion on the attractiveness of the Netherlands as a location, to test hypotheses 5 to 11 . Which factors are important to the manager to make the Netherlands an interesting choice for the establishment of an affiliate? And what factors make doing business there difficult? We asked questions regarding all seven groups of locational attractions as presented in Figure 5.1. Thirdly, we investigated the affiliate's behaviour. Did its activities change over time? Where do they sell? Do they intend to change their activities in the near future? Furthermore, we asked questions related to hypotheses 3 and 4 to find out if they considered alternative modes. We also asked questions to determine their most important strength while doing business in the Netherlands to test hypotheses 1 and 2. We used items that were selected based on our analysis of the Netherlands and its attractions in Chapter two and on Dunning's overviews of potential determinants of FDI within the OLI framework (Dunning 1980, 1988a, 1993, 1995, 2000, 2001).

The questionnaire was pre-tested - with respect to layout, content, item sequence, item wording, and item difficulty - at two electronics establishments. Respondents were asked to complete the questionnaire and comment on the questions. This resulted in minor changes. The questionnaire itself was conducted in fall 1999 and two reminders were sent with three weeks intervals. A follow-up for non-response was conducted and we found out that most non-participating firms were too busy, were approached with questionnaires too often, or were going through a major reorganisation.

The respondents were asked to indicate the importance of several characteristics and motives for investments in the Netherlands on a 5-point Likert-scale, where one is not important at all and five is most important. For each item, we have calculated the mean response regarding the importance of a variable on the decision to locate in the Netherlands or describing the strength of a foreign firm in the Dutch market ${ }^{18}$. We report the results of these analyses using the exact wording of the questionnaire, see Appendix $\mathrm{B}^{19}$ at the end of this study.

\footnotetext{
${ }_{18}^{17}$ We asked questions covering all elements of Figure 5.1.

${ }^{18}$ Overall, a mean larger than 3.70 indicates that the variable was an important factor motivating the decision to locate in the Netherlands. When the mean is smaller than 2.30 , the variable wasn't important. ${ }^{19}$ Given the exploratory nature of this questionnaire, we decided to use the individual items to test the hypotheses. Future research can use these results to formulate constructs. The results of the exploratory factor analyses can guide future studies.
} 
We control for firm characteristics that might influence the decision to locate in the Netherlands. We have determined whether these O, I, and L factors differ when considering the following characteristics of the affiliates, size, age, sales focus, activity (manufacturing, sales, R\&D, regional headquarters), and home country of their parent. We considered the differences in means of the importance of each item to the MNE affiliate. Given the sample size and the reasonable assumption that the sample is from a normal distribution, it was appropriate to use parametric tests (see Tatoglu and Glaister 1998a). We therefore used two-tailed t-tests and ANOVA $^{20}$ to determine the differences among determinants and strengths for groups of firms.

Given the large number of items, we conducted exploratory factor analyses to group the individual items into constructs and identify a structure within the set of observed variables. Although we had broadly classified the items in the questionnaire before sending it out, we use exploratory factor analysis to find out if our classification fits the actual data ${ }^{21}$. We used principal components analysis with varimax rotation. This is a data reduction technique aimed at constructing linear combinations of the original items that account for as much of the (original) variation as possible. The successive linear combinations are extracted in such a way that they account for successively smaller amounts of the total variation. The reported Cronbach alphas (Appendix 5.1) indicate the internal reliability of the constructs resulting from the factor analyses.

\subsection{The data}

In total 86 firms completed the questionnaire that was sent to them in fall and winter 1999 , resulting in a useful response rate of 18.3 percent $^{22}$. Using the DutchInvest database (discussed in Chapter two and Appendix A) we had selected all foreign firms that conducted activities in electronics, either in manufacturing or sales. The responding firms' home countries match the total sample firms' home countries quite well as can be seen from Table 5.1. The responding firms are therefore considered representative for the foreign investors in the Dutch electronics industry.

\footnotetext{
${ }^{20}$ If the value of the calculated F-statistic is significantly large, we can reject the hypothesis that the means across all groups are equal. The examination of the group means then allows the researcher to assess the relative standing of each group on the dependent measure (Hair Jr. et al., 1998).

${ }^{21} \mathrm{Had}$ we known exactly what relationships existed, confirmatory factor analysis would have been a more appropriate tool.

${ }^{22}$ This result is comparable to other mail questionnaire studies in the field. Ramaswami (1992)'s useful response rate was 18 percent (97 firms). Strizzi and Kindra (1997)'s response rate is 22 percent $(\mathrm{N}=61)$. Tucker et al. (1992)'s response rate is 20 percent $(\mathrm{N}=241$ ). Zhang and Yuk (1998)'s response rate to a fax questionnaire was 25.7 percent $(\mathrm{N}=69)$. Tatoglu and Glaister (1998) examine 93 firms, a response rate of 34.6 percent, slightly higher than average but they only approached firms that in principle were willing to participate. The same is true for Bell (1996), whose useable response consisted of 113 firms (38 percent of the sample). All firms were first contacted to find out their willingness to participate which let to a considerable reduction of the potential sample (from 458 to 303 firms).
} 
Table 5.1 Representativeness of the responding firms

\begin{tabular}{|c|c|c|c|c|}
\hline Country & Response & $\begin{array}{c}\text { Share of country in } \\
\text { total response }\end{array}$ & Total sample & $\begin{array}{c}\text { Share of country in } \\
\text { total sample }\end{array}$ \\
\hline Australia & & & 1 & 0.2 \\
\hline Austria & & & 3 & 0.6 \\
\hline Belgium & 5 & 5.8 & 22 & 4.7 \\
\hline Canada & & & 2 & 0.4 \\
\hline Denmark & 3 & 3.5 & 12 & 2.6 \\
\hline Finland & 1 & 1.2 & 2 & 0.4 \\
\hline France & 5 & 5.8 & 24 & 5.1 \\
\hline Germany & 21 & 24.4 & 120 & 25.6 \\
\hline Hong Kong & & & 2 & 0.4 \\
\hline Ireland & & & 1 & 0.2 \\
\hline Israel & 1 & 1.2 & 2 & 0.4 \\
\hline Italy & 1 & 1.2 & 6 & 1.3 \\
\hline Japan & 9 & 10.5 & 43 & 9.2 \\
\hline Liechtenstein & & & 0 & 0.0 \\
\hline Luxembourg & & & 2 & 0.4 \\
\hline Norway & & & 1 & 0.2 \\
\hline South Korea & & & 2 & 0.4 \\
\hline Sweden & 1 & 1.2 & 10 & 2.1 \\
\hline Switzerland & 7 & 8.1 & 33 & 7.0 \\
\hline Taiwan & 2 & 2.3 & 12 & 2.6 \\
\hline United Kingdom & 5 & 5.8 & 53 & 11.3 \\
\hline United States & 25 & 29.1 & 116 & 24.7 \\
\hline Total & 86 & & 469 & \\
\hline
\end{tabular}

An overview of the characteristics of the responding firms is given in Table 5.2. The sample consists of firms from within $(n=42)$ and outside $(n=44)$ the European Union (EU). The large majority of the establishments are accompanied by affiliates from the same parent in other European countries. Only 22.1 percent of the establishments are the only establishment of that parent within the European Union.

Forsgren et al. (1995) emphasise that with increasing internationalisation, a growing share of the resources are generated in dispersed foreign operations and the task to coordinate these operations grows, resulting in a high propensity to locate regional headquarters close to foreign operations. The spatial operating structure results in the need for a spatial organisational structure. The Netherlands is an attractive location for those regional headquarters. Twenty-six of the responding affiliates ( 30 percent) act as a regional headquarters for Europe, co-ordinating and supporting production and sales activities for the entire European continent. A little more than half of the responding firms were established after 1986, when the Single European Act was accepted that would result in an elimination of all remaining barriers to intra-EU trade and free flow of goods, services, and people. Most establishments (54) are wholly-owned subsidiaries (WOS). Few of the sample firms were started as joint-ventures or by taking over existing Dutch firms. The large majority has expansion plans for the near future. Most affiliates 
(94 percent) indicate that sales are a very important activity to the firm. Only 16 firms indicated that manufacturing was a (very) important activity.

Table 5.2 Characteristics of the firms responding to the questionnaire

\begin{tabular}{|c|c|c|c|}
\hline Characteristic & $\begin{array}{l}\text { Number of } \\
\text { firms }\end{array}$ & Characteristic & Number of firms \\
\hline $\begin{array}{l}\text { Country of origin } \\
\text { FU }\end{array}$ & 42 & $\begin{array}{l}\text { Year of establishment } \\
<1970\end{array}$ & 15 \\
\hline Belgium & 5 & $1971-1986$ & 27 \\
\hline Denmark & 3 & $1987-1998$ & 44 \\
\hline Finland & 1 & Affiliates in European countries & \\
\hline France & 5 & 0 & 19 \\
\hline Germany & 21 & $1-5$ & 20 \\
\hline Italy & 1 & $6-10$ & 25 \\
\hline Sweden & 1 & $11-15$ & 22 \\
\hline $\begin{array}{c}\text { UK } \\
\text { Switzerland }\end{array}$ & 7 & $\begin{array}{l}\text { Present activity indicated as important } \\
\text { (several answers possible, Question A20) }\end{array}$ & \\
\hline Israel & 1 & Manufacturing & 16 \\
\hline United States & 25 & Sales & 81 \\
\hline Japan & 9 & R\&D & 17 \\
\hline Taiwan & 2 & Logistics & 47 \\
\hline Mode & & Expansion plans & \\
\hline WOS & 54 & Yes & 59 \\
\hline Other & 31 & No & 27 \\
\hline Missing & 1 & & \\
\hline Size & & Regional Headquarters & \\
\hline $1-10$ & 25 & Yes & 26 \\
\hline $11-50$ & 40 & No & 59 \\
\hline 51 up & 21 & Missing & 1 \\
\hline
\end{tabular}

Source: Questionnaire results

\subsection{Testing the OLI for foreign electronics affiliates in the Netherlands}

In this section we present the results of the questionnaire study for all three groups of determinants: ownership, internalisation, and location.

\subsubsection{Ownership advantages}

The ownership advantages of the eclectic paradigm are unique internal factors that generate the firm's competitive advantage in the market place. We have asked the managers of the foreign electronics affiliates in the Netherlands to indicate the importance of 17 potential competitive strengths while doing business in the Dutch electronics industry. We classify those strengths in two broad groups: intangible assets and transaction based strengths. Intangible assets result from the resource structure of the firm. They include unique innovations, organisational and marketing systems, and human capital experience. Transaction-based strengths arise from the ability of the MNE to 
coordinate multiple and geographically dispersed value-added activities. They include experience in markets, management skills, and can result also result from favourable access to suppliers. The results of the questionnaire are presented in Table 5.3.

We find that overall the managers are quite optimistic about their strengths and that their competitive advantage is derived from both intangible assets and transaction related factors. From Table 5.3 it is clear that most firms strongly emphasise the importance of their marketing skills (4.00), closely followed by knowledge of the Dutch market (3.80). Managers also emphasise the quality of their distribution channels (3.76) and the international experience of the parent (3.89). A little less important for the competitive strength of foreign establishments in the Dutch electronics industry are headquarter support (3.52) and a certain level of independence from the headquarters (3.44).

With respect to their products, managers emphasise their superior technology (3.59) combined with price competitiveness (3.53). The managers also indicate that their products are tailored to the European market (3.39) and not so much specifically to the Dutch market only (2.88). In some cases they also indicate that their product occupies a niche in the market (3.24).

Table 5.3 Competitive strengths of foreign firms in the Dutch electronics industry

\begin{tabular}{|l|r|r|r|r|}
\hline Competitive strength & Type of strength & rank & mean & s.d. \\
\hline Marketing skills & Oa & 1 & 4.00 & 0.79 \\
International experience of parent & Ot & 2 & 3.89 & 1.01 \\
Knowledge of the Dutch market & Ot & 3 & 3.80 & 1.24 \\
Good distribution channels & Oa & 4 & 3.76 & 1.26 \\
Superior production technology & Oa & 5 & 3.59 & 1.26 \\
Price competitiveness & Oa & 6 & 3.53 & 1.09 \\
Headquarter support & Ot & 7 & 3.52 & 1.10 \\
Independence of headquarters & Ot & 8 & 3.44 & 0.94 \\
Products tailored to the European market & Oa & 9 & 3.39 & 1.26 \\
Product niche market & Oa & 10 & 3.24 & 1.32 \\
Economies of scale in production & Oa & 11 & 2.98 & 1.26 \\
Economies of scope in production & Ot & 12 & 2.95 & 1.24 \\
Products tailored to the Dutch market & Oa & 13 & 2.88 & 1.32 \\
Local government contacts & Ot & 14 & 2.71 & 1.17 \\
Dedicated suppliers & Ot & 15 & 2.47 & 1.21 \\
Lack of competition for product or service & Oa & 16 & 2.44 & 1.10 \\
Ability to raise capital at preferential rates & Ot & 17 & 2.27 & 1.11 \\
\hline
\end{tabular}

Source: Survey results, ordered by rank

$\mathrm{Oa}=$ intangible asset ownership advantage

$\mathrm{Ot}=$ transaction-specific ownership advantage

For the total sample the economies of scale (2.98) and scope (2.95) do not appear as strengths of the electronics affiliates in the Netherlands. The responding firms' managers indicate that it is not important to their competitive strength to be a monopolist in the market (2.44) or to have dedicated suppliers (2.47). Their contacts with local 
governments are not very important either (2.71). Least important turns out to be the ability to raise capital at preferential rates (2.27).

The overall results may conceal differences in strengths among firms classified by specific characteristics such as size, focus of sales activities, age, and function. These differences are indicated in Table 5.4. We find a number of significant differences among the competitive strengths of firms that focus their sales on the Netherlands and those that also supply other markets. First of all, the knowledge of the Dutch market obviously is more important to firms that target the Netherlands (4.16) or follow a mixed strategy (4.22) than for firms that mainly focus on exports (2.44). With respect to age, we find that 'younger' firms (established after the acceptance of the Single European Act in 1987) put significantly more emphasis on their independence from the headquarters (3.68) than older firms do (3.17). With respect to size, we find no differences at all.

The results indicate an interesting difference between firms that have a European parent and those affiliates whose parents are not in the EU. The latter group puts a much stronger emphasis on the economies of scale and scope in production. We see a similar result when considering the function of the affiliate. When the Dutch establishment acts as a regional headquarters for the parent firm, we again see a strong emphasis on the economies of scale and scope in production. We also find that regional headquarters put strong emphasis on products tailored to the European market, and do not value the knowledge of the Dutch market as much as the other firms do.

The correlation matrix of the 17 competitive strengths revealed a number of low to moderate intercorrelations between these different items. Due to potential statistical overlap, an attempt was made to determine the underlying primary dimensions governing the full set of strengths, using factor analysis. The null hypothesis that the population correlation matrix is an identity matrix is rejected by Bartlett's test of sphericity (approximate Chi-square $=515.5, \mathrm{df}=136$, significant at the 0.0001 level). Furthermore, the Kaiser-Mayer-Olkin measure of sampling adequacy is 0.761 . We can therefore conclude that factor analysis is appropriate for this sample to extract the underlying factors. Strengths with factor loading greater than or equal to 0.5 were grouped together for each factor derived. Table 5.5 shows the results of the factor analysis.

The factor analysis produced five underlying factors with eigenvalues over one that made good intuitive and conceptual sense and explained 63.2 percent of the observed variance. The five factors may be summarised as production-technology factors, headquarter characteristics, marketing factors, strategic product positioning, and institutional factors. Although they do not exactly match the expected classification of strengths in intangible assets and transaction-related strengths, we see considerable overlap. Factors one, three, and four together account for most intangible asset strengths. Factors two and five account for most transaction related factors. Two items (dedicated suppliers and products tailored to the Dutch market) do not load on any of the factors. 
Table 5.4 Differences in strength according to firm characteristics

\begin{tabular}{|c|c|c|c|c|c|c|c|c|c|c|c|c|c|}
\hline & & \multicolumn{3}{|c|}{ Sales focus ${ }^{1}$} & \multicolumn{2}{|c|}{ Age } & \multicolumn{3}{|c|}{ Size } & \multicolumn{2}{|c|}{$\begin{array}{l}\text { Parent } \\
\text { location }\end{array}$} & \multicolumn{2}{|c|}{ HQ } \\
\hline & $\begin{array}{c}\text { Type } \\
\text { of strength }\end{array}$ & NL & Mixed & Exports & $<1987$ & $>1987$ & small & medium & large & $\mathrm{EU}$ & Other & Yes & No \\
\hline $\begin{array}{l}\text { Products tailored to the } \\
\text { Dutch market }\end{array}$ & $\mathrm{Oa}$ & $3.12^{\mathrm{b}}$ & 2.91 & $2.28^{\mathrm{b}}$ & & & & & & & & & \\
\hline $\begin{array}{l}\text { Products tailored to the EU } \\
\text { market }\end{array}$ & $\mathrm{Oa}$ & $3.00^{\mathrm{db}}$ & $3.78^{d}$ & $3.72^{b}$ & & & & & & & & $4.08^{d}$ & $3.12^{\mathrm{d}}$ \\
\hline $\begin{array}{l}\text { Economies of scale in } \\
\text { production }\end{array}$ & $\mathrm{Oa}$ & $2.65^{\mathrm{ab}}$ & $3.26^{\mathrm{a}}$ & $3.29^{\mathrm{b}}$ & & & & & & $2.68^{d}$ & $3.26^{\mathrm{d}}$ & $3.40^{\mathrm{d}}$ & $2.79^{d}$ \\
\hline $\begin{array}{l}\text { Economies of scope in } \\
\text { production }\end{array}$ & Ot & $2.62^{\mathrm{a}}$ & $3.35^{\mathrm{a}}$ & 3.18 & & & & & & $2.60^{d}$ & $3.28^{\mathrm{d}}$ & $3.36^{\mathrm{d}}$ & $2.74^{\mathrm{d}}$ \\
\hline $\begin{array}{l}\text { Knowledge of the Dutch } \\
\text { market }\end{array}$ & Ot & $4.16^{\mathrm{e}}$ & $4.22^{f}$ & $2.44^{\text {ef }}$ & & & & & & $4.12^{d}$ & $3.50^{\mathrm{d}}$ & $3.04^{\mathrm{d}}$ & $4.16^{\mathrm{d}}$ \\
\hline Good distribution channels & $\mathrm{Oa}$ & 3.70 & $4.17^{c}$ & $3.33^{\mathrm{c}}$ & & & & & & & & & \\
\hline Local government contacts & Ot & 2.60 & $3.17^{c}$ & $2.33^{\mathrm{c}}$ & & & & & & $2.41^{d}$ & $2.98^{d}$ & & \\
\hline $\begin{array}{l}\text { Independence from the } \\
\text { headquaters }\end{array}$ & Ot & & & & $3.17^{d}$ & $3.68^{d}$ & & & & & & & \\
\hline $\begin{array}{l}\text { Significant difference betw } \\
\text { b Significant difference betw } \\
\text { ' Significant difference betw } \\
\text { The sales focus takes into acc } \\
\text { between } 10 \text { and } 90 \text { percent is g } \\
\text { exports from the Dutch establis }\end{array}$ & $\begin{array}{l}\text { een mean } 1 \text { an } \\
\text { een mean } 1 \text { ar } \\
\text { een mean } 2 \text { an }\end{array}$ & $\begin{array}{l}\text { nd } 2 \text { at th } \\
\text { nd } 3 \text { at th } \\
\text { nd } 3 \text { at th }\end{array}$ & $\begin{array}{l}\text { he } 0.101 \\
\text { he } 0.101 \\
\text { he } 0.101 \\
\text { f the affi }\end{array}$ & $\begin{array}{l}\text { level } \\
\text { level } \\
\text { level } \\
\text { liate's sales }\end{array}$ & When & $\begin{array}{r}{ }^{\mathrm{d}} \text { Sign } \\
{ }^{\mathrm{e}} \text { Sign } \\
{ }^{\mathrm{f}} \mathrm{Sign} \\
\text { ore than } 9\end{array}$ & $\begin{array}{l}\text { nificant } \\
\text { nificant } \\
\text { nificant } \\
0 \text { percen }\end{array}$ & 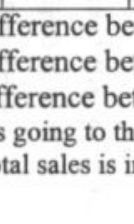 & $\begin{array}{l}\text { etween } \\
\text { etween } \\
\text { tween } \\
\text { ne Nethe }\end{array}$ & $\begin{array}{l}\text { ean } 1 \text { at } \\
\text { lean } 1 \text { ar } \\
\text { ean } 3 \text { ar } \\
\text { ands, the }\end{array}$ & $\begin{array}{l}\text { ad } 2 \text { at th } \\
\text { ad } 3 \text { at th } \\
\text { ad } 3 \text { at th } \\
\text { focus is }\end{array}$ & $\begin{array}{l}\text { e } 0.05 \\
\text { e } 0.05 \\
\text { Dutch. }\end{array}$ & $\begin{array}{l}\text { level } \\
\text { level } \\
\text { level } \\
\text { When }\end{array}$ \\
\hline
\end{tabular}


Table 5.5 Factors of competitive strength

\begin{tabular}{|c|c|c|c|c|c|}
\hline Factors & $\begin{array}{l}\text { Type of } \\
\text { strength }\end{array}$ & $\begin{array}{l}\text { Factor } \\
\text { loads }\end{array}$ & $\begin{array}{l}\text { Eigen- } \\
\text { value }\end{array}$ & $\begin{array}{l}\% \text { variance } \\
\text { explained }\end{array}$ & $\begin{array}{l}\text { Cum. } \\
\text { Percent }\end{array}$ \\
\hline $\begin{array}{l}\text { Factor 1: Production-technology factors } \\
\text { Products tailored to the European market } \\
\text { Economies of scale in production } \\
\text { Superior product technology } \\
\text { Economies of scope in production } \\
\text { Price competitiveness }\end{array}$ & $\begin{array}{l}\mathrm{Oa} \\
\mathrm{Oa} \\
\mathrm{Oa} \\
\mathrm{Ot} \\
\mathrm{Oa}\end{array}$ & $\begin{array}{l}0.745 \\
0.670 \\
0.662 \\
0.656 \\
0.622\end{array}$ & 2.261 & 15.420 & 15.420 \\
\hline $\begin{array}{l}\text { Factor 2: Headquarter characteristics } \\
\text { Independence of headquarters } \\
\text { International experience of parent } \\
\text { Headquarter support }\end{array}$ & $\begin{array}{l}\text { Ot } \\
\text { Ot } \\
\text { Ot }\end{array}$ & $\begin{array}{l}0.750 \\
0.742 \\
0.676\end{array}$ & 2.194 & 12.906 & 28.325 \\
\hline $\begin{array}{l}\text { Factor 3: Marketing factors } \\
\text { Knowledge of the Dutch market } \\
\text { Good distribution channels } \\
\text { Marketing skills }\end{array}$ & $\begin{array}{l}\mathrm{Ot} \\
\mathrm{Oa} \\
\mathrm{Oa}\end{array}$ & $\begin{array}{l}0.766 \\
0.684 \\
0.532\end{array}$ & 2.152 & 12.660 & 40.985 \\
\hline $\begin{array}{l}\text { Factor 4: Strategic product positioning } \\
\text { Product market niche } \\
\text { Lack of competitors for product or service }\end{array}$ & $\begin{array}{l}\mathrm{Oa} \\
\mathrm{Oa}\end{array}$ & $\begin{array}{l}0.809 \\
0.675\end{array}$ & 1.932 & 11.363 & 52.349 \\
\hline $\begin{array}{l}\text { Factor 5: Institutional factors } \\
\text { Ability to raise capital at preferential rates } \\
\text { Local government contacts }\end{array}$ & $\begin{array}{l}\mathrm{Ot} \\
\mathrm{Ot}\end{array}$ & $\begin{array}{l}0.858 \\
0.608\end{array}$ & 1.847 & 10.864 & 63.213 \\
\hline
\end{tabular}

Principle Components Factor analysis with varimax rotation

We have tested the reliability of the scales resulting from the factor analysis by calculating the Cronbach's alpha-values. These values are presented in the tables in the appendix to this chapter (Appendix 5.1). For all 17 items used in testing the strength of the firm in doing business in the Netherlands, we find that Cronbach's alpha is acceptably high $(0.86)^{23}$. The high value for the entire sample indicates that the items measure the same underlying construct suggesting that the data are uni-dimensional. When testing for the two dimensions specified beforehand (Ot and $\mathrm{Oa}$ ) we find that the Cronbach's alphas are still acceptably high $(0.75$ and 0.76$)$ but lower than for the entire set. This result indicates that the distinction between $\mathrm{Ot}$ and $\mathrm{Oa}$ is valid for this sample of firms. Considering that the further breakdown into five underlying factors results in Cronbach's alphas that vary considerably $(0.44-0.82)^{24}$ we conclude that the exploratory factor analysis conducted here does not improve our understanding of the possible underlying dimensions of the $\mathrm{Oa}$ and Ot advantages of firms.

\footnotetext{
${ }^{23}$ In general, Cronbach's alpha values $>0.70$ are acceptable. In that case the inter-item correlations are high which is evidence that the items are measuring the same underlying construct. One must keep in mind that generally the reliability improves with the number of items included.

${ }^{24}$ Although these values are low, the factor analysis is included in this chapter as part of the exploratory search for ownership-advantages constructs. Future research can build upon these first attempts. For the competitive strength factor analysis, most problems occur with the items measuring marketing skills. The low item-total correlations indicate that this construct can be improved upon significantly in future research.
} 
The overall results confirm our expectation that both asset-related ownership advantages and transaction-specific ownership advantages influence a foreign firm's decision to start activities in a host country. Managers indicate that both marketing skills and good distribution channels are very important in explaining their strength in doing business in the Netherlands, offering support for hypothesis 1. Furthermore, managers also mention that knowledge of the Dutch market and the international experience of the parent are important explanations of their strength. When they focus on supplying the EU market (instead of the Netherlands) or are a European headquarters, their knowledge of the European market is very important as well. These factors offer support for hypothesis 2 .

\subsubsection{Internalisation advantages}

We have tested both cost and control factors related to internalisation. The results of our analyses are presented in Table 5.6. We see that none of these factors offer an important explanation for the choice for a Dutch establishment over alternative modes. The cost factor (high costs in making and enforcing contracts) does not appear to matter nor do any of the control factors. The Dutch establishment is not motivated by a good acquisition opportunity. For most managers it was not important that no agents or licensing partners were available. Furthermore, the price of exports is no problem either. We therefore find no support for hypotheses 3 and 4 for this sample of firms in the Dutch electronics industry.

Table 5.6 Internalisation reasons

\begin{tabular}{|l|l|r|r|r|}
\hline Factor & Type & Rank & Mean & S.D. \\
\hline Acquisition opportunity & Control & 1 & 2.41 & 1.42 \\
No good agents available & Control & 2 & 2.20 & 1.31 \\
High costs of making and enforcing contracts & Cost & 3 & 2.16 & 1.02 \\
Exports to the Netherlands too expensive & Control & 4 & 1.91 & 1.02 \\
No good licensing partner available & Control & 5 & 1.84 & 1.03 \\
\hline
\end{tabular}

Source: Questionnaire results, ordered by rank

We conducted an exploratory factor analysis (Table 5.7) to determine any underlying constructs. The null hypothesis that the population correlation matrix is an identity matrix is rejected by Bartlett's test of sphericity (approximate Chi-square $=121.7$, $\mathrm{df}=10$, significant at the 0.0001 level). Furthermore, the Kaiser-Mayer-Olkin measure of sampling adequacy is 0.635 . We can therefore conclude that factor analysis is appropriate for this sample to extract the underlying factors.

The factor analysis reveals two distinct factors (eigen values $>1$ ), costs of conducting activities and control over activities but these factors do not exactly match the specified distinction between cost and control issues we expected to find. However, the items 
loading on factor 1 all involve costs-related aspects while the items loading on factor 2 mainly involve alternative modes for greenfield establishments.

Table 5.7 Factor analysis internalisation

\begin{tabular}{|l|l|l|l|r|r|}
\hline Factors & Type & $\begin{array}{l}\text { Factor } \\
\text { loads }\end{array}$ & $\begin{array}{l}\text { Eigen- } \\
\text { value }\end{array}$ & $\begin{array}{l}\text { \% variance } \\
\text { explained }\end{array}$ & $\begin{array}{l}\text { Cum. } \\
\text { Percent }\end{array}$ \\
\hline Factor 1: Costs of conducting activities & & & 2.449 & 49.0 & 49.0 \\
High costs of making and enforcing contracts & & 0.849 & & & \\
Exports to the Netherlands too expensive & & 0.677 & & & \\
Acquisition opportunity & & 0.618 & & & \\
\hline Factor 2: Control over activities & & & 1.035 & & \\
No good licensing partner available & & 0.881 & & & \\
No good agents available & & 0.910 & & & \\
\hline
\end{tabular}

Principle Components Factor analysis with varimax rotation

Appendix 5.1 reveals that the reliability of the scales is limited. Considerable improvement can therefore be made testing the internalisation advantages to foreign firms in the Netherlands. The items presented here only offer a first exploration.

\subsubsection{Locational advantages}

Having established the particular strengths of foreign affiliates in the Dutch electronics industry, we now discuss the locational attractions that motivated MNEs to start activities in the Netherlands. We have tested a list of 46 locational variables that were considered important potential determinants in the specific Dutch case. The overall results for the entire sample of firms are presented in Table 5.8, where all locational determinants are ranked using their mean which gives an indication of the overall importance of a specific factor on the locational choice for the Netherlands for the entire sample of electronics firms.

It is clear that the most important factor attracting firms to the Netherlands is the need to be close to the customer (4.21), closely followed by the market growth potential (3.72). Other factors that were important in determining the choice for the Netherlands include the multi-lingual population (3.31), the need to be close to key industry markets (3.29), following a client (3.19), the Dutch market size and purchasing power of the Dutch consumer (3.13). Furthermore, regional economic growth (3.09), the economic and political stability (3.07), the presence of qualified and experienced technical staff (3.07), the Dutch membership of the European Union (3.06), and the location within the Benelux (3.06) also attracted foreign affiliates to the Dutch electronics sector.

\footnotetext{
${ }^{25}$ Acquisition opportunity's item-to-total correlation $(0.2641)$ is below the 0.3 -threshold that is usually considered acceptable. The item therefore does not correlate very well with the overall scale reducing the reliability of the overall analysis.
} 
Table 5.8 Overview of the locational determinants of FDI in the Netherlands

\begin{tabular}{|c|c|c|c|c|}
\hline Location factor & Type & Rank & Mean & S.D. \\
\hline Being close to your customer & Market & 1 & 4.21 & 0.95 \\
\hline Market growth potential & Market & 2 & 3.72 & 1.22 \\
\hline Multi-lingual population & Resources & 3 & 3.31 & 1.42 \\
\hline Being close to key industry markets & Resources & 4 & 3.29 & 1.42 \\
\hline Following client & Market & 5 & 3.19 & 1.44 \\
\hline Dutch market size and purchasing power Dutch consumers & Market & 6 & 3.13 & 1.36 \\
\hline Regional economic growth & Economy & 7 & 3.09 & 1.27 \\
\hline Qualified and experienced technical staff & Resources & 8 & 3.07 & 1.32 \\
\hline Economic and political stability & Economy & 9 & 3.07 & 1.24 \\
\hline Location within Benelux & Market & 10 & 3.06 & 1.49 \\
\hline Dutch membership of the European Union & Economy & 11 & 3.06 & 1.39 \\
\hline Open investment climate & Economy & 12 & 2.97 & 1.33 \\
\hline Availability of management skills & Resources & 13 & 2.91 & 1.23 \\
\hline Stable exchange rates & Economy & 14 & 2.86 & 1.33 \\
\hline Easy access to European market & Market & 15 & 2.85 & 1.61 \\
\hline Purchasing power Dutch firms & Market & 16 & 2.84 & 1.37 \\
\hline Tax regime & Incentives & 17 & 2.80 & 1.27 \\
\hline High labour productivity & Resources & 18 & 2.76 & 1.26 \\
\hline Following competition & Market & 19 & 2.71 & 1.31 \\
\hline Schiphol airport & Infrastructure & 20 & 2.63 & 1.46 \\
\hline Availability of office space & Infrastructure & 21 & 2.59 & 1.29 \\
\hline Favourable customs policy & Barriers & 22 & 2.58 & 1.27 \\
\hline Availability of ITC resources & Resources & 23 & 2.57 & 1.33 \\
\hline Motorway network & Infrastructure & 24 & 2.55 & 1.39 \\
\hline Central location in Europe & Market & 25 & 2.52 & 1.59 \\
\hline Comprehensive legal system & Society & 26 & 2.51 & 1.15 \\
\hline Availability of truck transportation & Infrastructure & 27 & 2.50 & 1.46 \\
\hline Price of office space & Infrastructure & 28 & 2.47 & 1.21 \\
\hline Potential client wanted a Dutch establishment & Market & 29 & 2.43 & 1.56 \\
\hline Availability of warehousing facilities & Infrastructure & 30 & 2.35 & 1.41 \\
\hline Efficient bureaucracy & Society & 31 & 2.33 & 1.12 \\
\hline Availability of industrial parks & Infrastructure & 32 & 2.29 & 1.24 \\
\hline Lower labor costs & Resources & 33 & 2.22 & 1.05 \\
\hline Diversification of activities & Market & 34 & 2.21 & 1.11 \\
\hline Price of road transportation & Infrastructure & 35 & 2.17 & 1.23 \\
\hline Government subsidies & Incentives & 36 & 2.16 & 1.15 \\
\hline Access to local financial resources & Economy & 37 & 2.15 & 1.15 \\
\hline Fear of import restrictions due to European Union & Barriers & 38 & 2.14 & 1.15 \\
\hline Price of warehousing facilities & Infrastructure & 39 & 2.09 & 1.20 \\
\hline
\end{tabular}


Table 5.8 Overview of the locational determinants of FDI in the Netherlands (continued)

\begin{tabular}{|l|l|r|r|r|}
\hline Location factor & Type & Rank & Mean & S.D. \\
\hline Proximity to important research institutes and universities & Resources & 40 & 2.07 & 1.16 \\
Harbours & Infrastructure & 41 & 1.94 & 1.23 \\
Saturated home market & Market & 42 & 1.91 & 1.14 \\
Railways & Infrastructure & 43 & 1.70 & 0.96 \\
Being close to your supplier & Resources & 44 & 1.68 & 0.98 \\
Easy access to raw materials & Resources & 45 & 1.60 & 0.91 \\
Waterways & Infrastructure & 46 & 1.53 & 0.86 \\
\hline
\end{tabular}

Source: questionnaire results, ordered by rank

Contrary to the general perception, infrastructural factors don't matter much for the whole sample of electronics firms. Inward investments are not motivated by the easy access to raw materials either (1.60), which is not surprising considering the high-tech nature of the sector, the sales orientation of the affiliates, and the limited availability of raw materials in the Netherlands (natural gas excluded). Foreign firms in the Dutch electronics sector do not follow their supplier (1.68) and are not pushed out of their home market due to lack of demand (1.91).

Again, we find considerable differences in locational determinants between firms when controlling for the affiliates' characteristics. With respect to size, we find that particularly smaller firms are emphasising characteristics related to the Dutch market, as can be seen from Table 5.9. Firms employing up to ten people seem more focused on the Netherlands than larger firms and value the Dutch market size and purchasing power of Dutch consumers and firms much more than large firms. Large firms, on the other hand, value the availability of information and communication technology more. These technologies enhance the possibilities for doing business activities across national borders (e.g. within the European market) and facilitate communications with the MNE headquarters. For medium-sized firms the tax regime is seen as a favourable influence on their decision to locate in the Netherlands. This effect, however, is only small (3.10).

Almost fifty percent of the firms in our sample serve more than just the Dutch market. Apparently they value the Netherlands not only for its country-specific characteristics, but also for its location in and the ease of access to Europe. From Table 5.9 it is clear that important differences in locational determinants exist between the firms that focus only on the Netherlands (group 1) and firms that follow a mixed strategy (group 2) or use the Netherlands as an export base (group 3). The need to be close to your customer is important to all respondents. However, it is significantly more important for firms that focus on the Netherlands (4.41) or follow a mixed strategy (4.36) than for firms that use the Netherlands as an export base (3.56). The Dutch market size and the purchasing power of Dutch consumers are important for group 1 (3.61) and 2 (3.18), but unimportant for group three (1.86). 
Table 5.9 Differences in locational determinants according to firm characteristics

\begin{tabular}{|c|c|c|c|c|c|c|c|c|c|c|c|c|c|}
\hline & \multirow[t]{2}{*}{ Type } & \multicolumn{3}{|c|}{ Sales focus ${ }^{1}$} & \multicolumn{2}{|c|}{ Age } & \multicolumn{3}{|c|}{ Size } & \multicolumn{2}{|c|}{ Parent location } & \multicolumn{2}{|c|}{ HQ } \\
\hline & & NL & Mixed & Exports & $<1987$ & $>1987$ & $\begin{array}{r}\text { Small } \\
(1-10)\end{array}$ & $\begin{array}{r}\text { Medium } \\
(11-50)\end{array}$ & $\begin{array}{l}\text { Large } \\
(>50)\end{array}$ & $\mathrm{EU}$ & Other & Yes & No \\
\hline Market growth potential & Market & & & & & & & & & $4.05^{\mathrm{d}}$ & $3.40^{\mathrm{d}}$ & $3.20^{\mathrm{d}}$ & $3.93^{\mathrm{d}}$ \\
\hline $\begin{array}{l}\text { Dutch market size and purchasing } \\
\text { power Dutch consumers }\end{array}$ & Market & $3.61^{\mathrm{e}}$ & $3.18^{f}$ & $1.89^{e f}$ & $3.45^{\mathrm{d}}$ & $2.81^{\mathrm{d}}$ & $3.71^{\mathrm{ac}}$ & $2.98^{\mathrm{a}}$ & $2.76^{\mathrm{e}}$ & $3.62^{\mathrm{d}}$ & $2.65^{\mathrm{d}}$ & $2.20^{4}$ & $3.51^{\mathrm{d}}$ \\
\hline Purchasing power Dutch firms & Market & & & & & & $3.50^{\mathrm{ac}}$ & $2.75^{\mathrm{a}}$ & $2.24^{\circ}$ & & & $2.12^{\mathrm{d}}$ & $3.14^{\mathrm{d}}$ \\
\hline Saturated home market & Market & & & & & & $1.63^{\mathrm{a}}$ & $2.00^{\mathrm{a}}$ & 2.29 & & & & \\
\hline Diversification of activities & Market & & & & & & $1.62^{\mathrm{e}}$ & $2.35^{\mathrm{c}}$ & $2 .^{50 \mathrm{ce}}$ & & & & \\
\hline Being close to the customer & Market & $4.41^{\mathrm{e}}$ & $4.36^{t}$ & $3.56^{\text {ef }}$ & & & & & & & & & \\
\hline Being close to key industry markets & Resources & & & & $3.02^{\mathrm{a}}$ & $3.56^{\mathrm{a}}$ & & & & & & & \\
\hline Location within Benelux & Market & & & & & & $3.46^{\circ}$ & $3.23^{f}$ & $2.29^{\text {ef }}$ & & & & \\
\hline Easy access to the European market & Market & $2.02^{\mathrm{de}}$ & $3.36^{\mathrm{d}}$ & $4.11^{\mathrm{e}}$ & & & & & & $2.05^{\mathrm{d}}$ & $3.63^{\mathrm{d}}$ & $4.56^{\mathrm{d}}$ & $2.15^{\mathrm{d}}$ \\
\hline Central location in Europe & Market & $1.61^{\mathrm{de}}$ & $3.14^{\mathrm{d}}$ & $3.83^{\mathrm{c}}$ & & & & & & $1.76^{\mathrm{d}}$ & $3.26^{\mathrm{d}}$ & $4.32^{\mathrm{d}}$ & $1.78^{\mathrm{d}}$ \\
\hline $\begin{array}{l}\text { Potential client wanted a Dutch } \\
\text { establishment }\end{array}$ & Market & $2.73^{\circ}$ & 2.38 & $1.67^{e}$ & $2.74^{a}$ & $2.12^{\mathrm{a}}$ & & & . & & & $1.80^{\mathrm{d}}$ & $2.72^{\mathrm{d}}$ \\
\hline Harbours & Infrastructure & $1.50^{\mathrm{de}}$ & $2.35^{\mathrm{d}}$ & $2.44^{\circ}$ & & & & & & $1.62^{\mathrm{d}}$ & $2.25^{\mathrm{d}}$ & $2.62^{\mathrm{d}}$ & $1.66^{\mathrm{d}}$ \\
\hline Waterways & Infrastructure & & & & $1.33^{\mathrm{d}}$ & $1.73^{\mathrm{d}}$ & & & & & & & \\
\hline Schiphol Airport & Infrastructure & $2.02^{\mathrm{de}}$ & $2.96^{\mathrm{d}}$ & $3.61^{e}$ & & & & & & $1.98^{\mathrm{d}}$ & $3.25^{\mathrm{d}}$ & $3.69^{\mathrm{d}}$ & $2.19^{d}$ \\
\hline Motorway network & Infrastructure & $2.11^{\mathrm{ac}}$ & $2.87^{\mathrm{a}}$ & $3.17^{\circ}$ & & & & & & & & $3.15^{\mathrm{d}}$ & $2.31^{\mathrm{d}}$ \\
\hline Availability of truck transportation & Infrastructure & $2.02^{\text {bd }}$ & $2.94^{\mathrm{d}}$ & $3.04^{b}$ & & & & & & $2.17^{\mathrm{d}}$ & $2.82^{\mathrm{d}}$ & $3.27^{\mathrm{d}}$ & $2.19^{d}$ \\
\hline Price of road transportation & Infrastructure & $1.80^{\mathrm{d}}$ & $2.44^{\mathrm{d}}$ & 2.65 & & & & & & $1.88^{\mathrm{d}}$ & $2.45^{\mathrm{d}}$ & $2.81^{\mathrm{d}}$ & $1.92^{\mathrm{d}}$ \\
\hline $\begin{array}{l}\text { Availability of warehousing } \\
\text { facilities }\end{array}$ & Infrastructure & & & & & & & & & $1.98^{\mathrm{d}}$ & $2.70^{\mathrm{d}}$ & $3.35^{\mathrm{d}}$ & $1.93^{\mathrm{d}}$ \\
\hline Price of warehousing facilities & Infrastructure & & & & & & & & & $1.79^{\mathrm{d}}$ & $2.39^{\mathrm{d}}$ & $2.92^{\mathrm{d}}$ & $1.75^{\mathrm{d}}$ \\
\hline ICT resources & Infrastructure & $2.16^{\mathrm{e}}$ & 2.78 & $3.22^{\mathrm{e}}$ & $2.29^{\mathrm{a}}$ & $2.84^{\mathrm{a}}$ & $2.32^{\circ}$ & $2.38^{r}$ & $3.24^{\text {ef }}$ & $2.19^{\mathrm{d}}$ & $2.93^{\mathrm{d}}$ & $3.23^{\mathrm{d}}$ & $2.31^{\mathrm{d}}$ \\
\hline Availability of industrial parks & Infrastructure & $1.95^{\circ}$ & 2.39 & $2.94^{\circ}$ & $2.02^{\circ}$ & $2.55^{*}$ & & & & $1.93^{\mathrm{d}}$ & $2.64^{d}$ & & \\
\hline
\end{tabular}




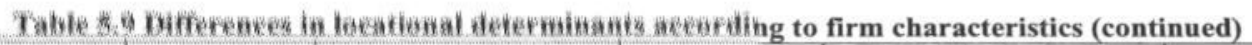

\begin{tabular}{|c|c|c|c|c|c|c|c|c|c|c|c|c|c|}
\hline & \multirow[t]{2}{*}{ Trye } & \multicolumn{3}{|c|}{ Soles thetis. } & \multicolumn{2}{|c|}{ thet } & \multicolumn{3}{|c|}{ Size } & \multicolumn{2}{|c|}{ Parent location } & \multicolumn{2}{|c|}{ HQ } \\
\hline & & Whit & blized & Fiprotis. & 51882 & 21987 & Small & Medium & Large & EU & Other & Yes & No \\
\hline 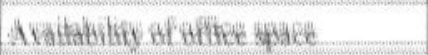 & litffistithettite. & $311^{8}$ & 2.74 & -3.56 & & & & & & $2.33^{\mathrm{a}}$ & $2.84^{\mathrm{a}}$ & $3.31^{\mathrm{d}}$ & $2.31^{\mathrm{d}}$ \\
\hline 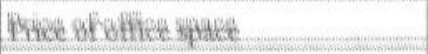 & 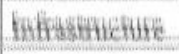 & 1. $88^{2}$ & 2. $7 A^{6}$ & 3. 38 & & & & & & $2.10^{\mathrm{d}}$ & $2.82^{\mathrm{d}}$ & $3.27^{\mathrm{d}}$ & $2.14^{\mathrm{d}}$ \\
\hline Hawer Hawour ecsts & Besouthes. & 1.688 the & 2.484 & 2.26 & & & & & & $1.98^{\mathrm{d}}$ & $2.47^{\mathrm{d}}$ & $2.76^{\mathrm{d}}$ & $2.02^{\mathrm{d}}$ \\
\hline 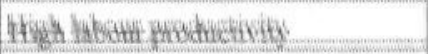 & Besothees. & $23 x^{4}$ & $3.81^{3}$ & 3. 62 ? & & & & & & $2.38^{\mathrm{d}}$ & $3.11^{\mathrm{d}}$ & $3.31^{\mathrm{d}}$ & $2.54^{\mathrm{d}}$ \\
\hline 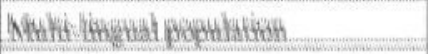 & Qessobitices & 2. $5 y$ & $3: 83^{4}$ & $4+4^{n}$ & $3.063^{4}$ & $3.61^{d}$ & & & & $2.81^{\mathrm{d}}$ & $3.80^{\mathrm{d}}$ & $4.38^{d}$ & $2.88^{d}$ \\
\hline 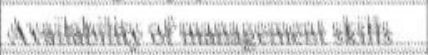 & 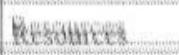 & $2 \times 3^{4}$ & $3: 22^{4}$ & $3:(B)^{4}$ & & $\operatorname{lin}_{1}$ & & & & $2.48^{\mathrm{d}}$ & $3.32^{\mathrm{d}}$ & $3.58^{\mathrm{d}}$ & $2.64^{\mathrm{d}}$ \\
\hline 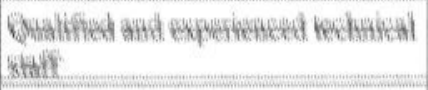 & 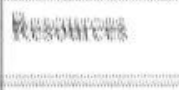 & a.kative & $3.3 y^{2}$ & $3: 6 \%$ & & & & & & & & $3.58^{d}$ & $2.88^{\mathrm{d}}$ \\
\hline 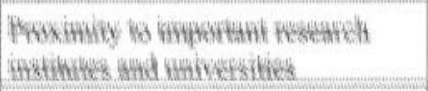 & Pensobtices & $1.933^{k 6}$ & $339^{2}$ & $2.44^{k}$ & & & & & & $1.71^{\mathrm{d}}$ & $2.41^{\mathrm{d}}$ & & \\
\hline 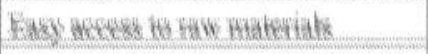 & Pesiantees. & $134^{2}$ & 134 & $1.94:$ & & 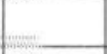 & & & & $1.38^{\mathrm{d}}$ & $1.82^{\mathrm{d}}$ & $2.08^{\mathrm{d}}$ & $1.41^{d}$ \\
\hline 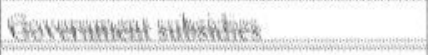 & litechtixes. & 1.824 & 3.32 & $2.72^{k}$ & & 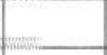 & & & & & & $2.58^{\mathrm{a}}$ & $2.00^{\mathrm{a}}$ \\
\hline The weititi & litectitswes. & $2.43^{4}$ & 3 is & 3.33 & & 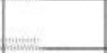 & $2.28^{\mathrm{d}}$ & $3.10^{\mathrm{d}}$ & 2.86 & $2.33^{\mathrm{d}}$ & $3.25^{\mathrm{d}}$ & $3.69^{\mathrm{d}}$ & $2.44^{\mathrm{d}}$ \\
\hline 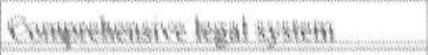 & sockety & $33^{6}$ & $2 B 1$ & $3 a^{4} y^{4}$ & & & & & & $2.21^{\mathrm{d}}$ & $2.80^{\mathrm{d}}$ & $3.00^{\mathrm{d}}$ & $2.32^{d}$ \\
\hline 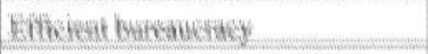 & sownetix & $1.63^{4 t}$ & $361^{d}$ & $2.78^{\circ}$ & $2: 12^{4}$ & $2.52^{\mathrm{a}}$ & & & & $1.93^{\mathrm{d}}$ & $2.70^{\mathrm{d}}$ & $3.12^{\mathrm{d}}$ & $2.00^{d}$ \\
\hline 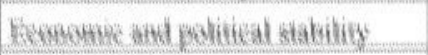 & Exonotury & $3.80^{5}$ & 313 & $3.81^{k}$ & & & $2.56^{\mathrm{a}}$ & $3.28^{\mathrm{a}}$ & 3.29 & $2.69^{d}$ & $3.43^{\mathrm{d}}$ & $3.73^{\mathrm{d}}$ & $2.81^{\mathrm{d}}$ \\
\hline 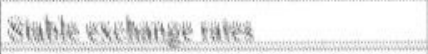 & Eetobstaty & $348^{b i d}$ & $3.3 b^{d}$ & $3.28^{4}$ & & & & & & $2.52^{\mathrm{d}}$ & $3.18^{d}$ & $3.50^{\mathrm{d}}$ & $2.61^{d}$ \\
\hline 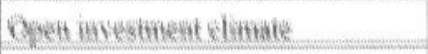 & Beatiothy & $3.55^{4}$ & 3,17 & $367^{*}$ & & & & & & $2.64^{d}$ & $3.27^{\mathrm{d}}$ & $3.69^{d}$ & $2.68^{d}$ \\
\hline Dosteh satemberstigy of ot & Elabothy & $y^{2}, z^{4 k}$ & $3.4 k^{d}$ & $3.78^{i}$ & & & & & & $2.74^{d}$ & $3.36^{\mathrm{d}}$ & $3.88^{\mathrm{d}}$ & $2.73^{\mathrm{d}}$ \\
\hline 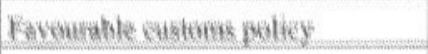 & Bartiers & $2.11^{4 k}$ & $3.00^{4}$ & $30 g^{r}$ & & & & & & $2.24^{\mathrm{d}}$ & $2.91^{\mathrm{d}}$ & $3.42^{\mathrm{d}}$ & $2.24^{\mathrm{d}}$ \\
\hline 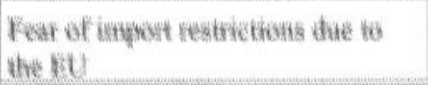 & Bartiers & $1.75^{\text {WE }}$ & $2.33^{4}$ & $2.72^{4}$ & & & & & & $1.83^{\mathrm{d}}$ & $2.43^{d}$ & $2.81^{\mathrm{d}}$ & $1.86^{\mathrm{d}}$ \\
\hline
\end{tabular}

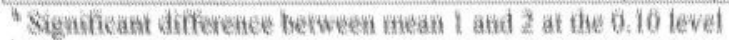

Significant difference between mean 1 and 2 at the 0.05 level

"Sigtatciant differenew ketween mean 1 and 3 at the 0.10 level

' Significant difference between mean 1 and 3 at the 0.05 level

* Sigaticant difference berween mean 2 and 3 at the 0.10 level

${ }^{\mathrm{f}}$ Significant difference between mean 2 and 3 at the 0.05 level

1 sere betw 1 at Table 8.4 
On the other hand, the multi-lingual population is a significantly larger attraction for firms that focus on exporting (4.44) or follow a mixed strategy (3.83) than for firms that concentrate on the Netherlands (2.83). The same is true for qualified and experienced technical staff and membership of the European Union.

Not surprisingly we find that firms that export (part or all of) their goods from their establishment in the Netherlands value the access to the European market and the central location within Europe significantly more than those that focus on the Dutch market only. Although these factors at first glance don't seem to matter much for the entire sample, the ANOVA analyses reveal that market focus strongly influences the importance of these factors. The same is true for most infrastructural factors. Firms that export value Schiphol airport, the motorway network, the availability of truck transportation, and the price and availability of office space significantly more than firms that only focus on the Netherlands. These affiliates also emphasise the favourable tax regime, open investment climate, and favourable customs policy as important determinants of their choice for the Netherlands. Furthermore, they also put strong emphasis on several resources. They value the availability of management skills and the high labour productivity in the Netherlands much more than firms that focus on the Dutch market only do.

We find relatively few differences among firms that were established before the acceptance of the Single European Act ('older' firms) and those that started activities after ('younger' firms). For the latter group we find that being close to key industrial markets (3.56) and the multi-lingual population (3.61) are significantly more important than for the 'older' firms (3.02 and 3.00 respectively). On the other hand we find that 'older' firms put much more emphasis on the Dutch market size and the purchasing power of Dutch consumers (3.45) than 'younger' firms (2.81).

We find many significant differences in the locational determinants between firms that have their home country in or outside the European Union. Firms with non-EU parents put much more emphasis on the location within the Benelux, the easy access to Europe, the EU-membership of the Netherlands, and Schiphol airport.

Furthermore, non-EU affiliates value the high labour productivity and available management skills, factors that seem relatively unimportant for the entire sample (see Table 5.8). They put much more emphasis on the stable economic and political situation in the Netherlands. Affiliates whose home countries are among the EU-member states put strong emphasis on the market growth potential and the Dutch market size.

We find that firms that act as regional headquarters for their parent firm put strong emphasis on significantly different locational factors than firms that do not have this special task (see Table 5.9). Not surprisingly, we find that regional headquarters put strong emphasis on infrastructural facilities - Schiphol airport, warehousing facilities, ICT, and office spaces - and the access to the European Union. Furthermore, they strongly emphasise the resource availability, including both management and technical skills, and the high productivity of the multi-lingual labour force. We also find that regional headquarters value many economic and political factors that appear unimportant 
for the entire sample of firms such as the legal system, the favourable customs policy, and the efficient bureaucracy.

Again, the correlation matrix of the 46 locational factors revealed a number of low to moderate intercorrelations between these different items. Due to potential statistical overlap, an attempt was made to determine the underlying primary dimensions governing the full set of locational factors. The null hypothesis that the population correlation matrix is an identity matrix is rejected by Bartlett's test of sphericity (approximate Chisquare $=3148.7$, df $=1035$, significant at the 0.0001 level). Furthermore, the KaiserMayer-Olkin measure of sampling adequacy is 0.761 . We can therefore conclude that factor analysis is appropriate for this sample. Exploratory factor analysis using varimax rotation was used to extract the underlying factors. Location variables with factor loading greater than 0.5 were grouped together for each factor derived.

The factor analysis produced eleven underlying factors with eigenvalues over one, explaining 75.7 percent of the observed variance, as shown in Table 5.10. The factors are presented in the order in which they were extracted. Management skills loaded on two factors. We have grouped this variable with the factor for which it had the highest loading. Five variables did not load on any factor: proximity to universities (rank 40), diversification of activities (rank 34), being close to key industry markets (rank 4), being close to your customer (rank 1), and following competition (rank 19).

Table 5.10 Factors of locational determinants

\begin{tabular}{|c|c|c|c|c|c|}
\hline Factors & Type & Loads & $\begin{array}{c}\text { Eigen } \\
\text { value }\end{array}$ & $\begin{array}{r}\% \text { variance } \\
\text { explained }\end{array}$ & $\begin{array}{r}\text { Cum. } \\
\%\end{array}$ \\
\hline Factor 1: Economic and legal system & & & 16.34 & 35.52 & 35.52 \\
\hline Dutch membership of the European Union & Economy & 0.824 & & & \\
\hline Fear of import restrictions due to European Union & Barriers & 0.784 & & & \\
\hline Regional economic growth & Economy & 0.748 & & & \\
\hline Stable exchange rates & Economy & 0.748 & & & \\
\hline Open investment climate & Economy & 0.746 & & & \\
\hline Comprehensive legal system & Society & 0.700 & & & \\
\hline Economic and political stability & Economy & 0.686 & & & \\
\hline Efficient bureaucracy & Society & 0.598 & & & \\
\hline Tax regime & Incentives & 0.528 & & & \\
\hline Favourable customs policy & Barriers & 0.513 & & & \\
\hline Factor 2: Transportation and storage infrastructure & & & 3.89 & 8.46 & 43.98 \\
\hline Price of road transportation & Infrastructure & 0.777 & & & \\
\hline Availability of truck transportation & Infrastructure & 0.724 & & & \\
\hline Availability of warehousing & Infrastructure & 0.710 & & & \\
\hline Price of warehousing & Infrastructure & 0.701 & & & \\
\hline Railways & Infrastructure & 0.675 & & & \\
\hline Harbours & Infrastructure & 0.672 & & & \\
\hline Waterways & Infrastructure & 0.633 & & & \\
\hline
\end{tabular}


Table 5.10 Factors of locational determinants (continued)

\begin{tabular}{|c|c|c|c|c|c|}
\hline Factors & Type & Loads & $\begin{array}{l}\text { Eigen } \\
\text { value }\end{array}$ & $\begin{array}{r}\% \text { variance } \\
\text { explained }\end{array}$ & $\begin{array}{r}\text { Cum. } \\
\%\end{array}$ \\
\hline Factor 3: Office infrastructure and staff & & & 2.86 & 6.22 & 50.20 \\
\hline Availability of office space & Infrastructure & 0.776 & & & \\
\hline Qualified and experienced technical staff & Resources & 0.681 & & & \\
\hline Price of office space & Infrastructure & 0.638 & & & \\
\hline Availability of industrial parks & Infrastructure & 0.616 & & & \\
\hline Motorway network & Infrastructure & 0.608 & & & \\
\hline Availability of management skills & Resources & 0.587 & & & \\
\hline Availability of ICT resources & Resources & 0.524 & & & \\
\hline Factor 4: International orientation and productivity & & & 2.15 & 4.68 & 54.88 \\
\hline High labour productivity & Resources & 0.680 & & & \\
\hline Lower labour costs & Resources & 0.656 & & & \\
\hline Schiphol airport & Infrastructure & 0.649 & & & \\
\hline Multi-lingual population & Resources & 0.644 & & & \\
\hline Factor 5: Customer base & & & 1.94 & 4.22 & 59.11 \\
\hline Potential client wanted a Dutch establishment & Market & 0.854 & & & \\
\hline Dutch market size and purchasing power Dutch & Market & 0.699 & & & \\
\hline $\begin{array}{l}\text { consumer } \\
\text { Following client }\end{array}$ & Market & 0.603 & & & \\
\hline Factor 6: Accessibility & & & 1.53 & 3.33 & 62.44 \\
\hline Easy access to European market & Market & 0.770 & & & \\
\hline Central location in Europe & Market & 0.675 & & & \\
\hline Factor 7: Availability of inputs to production & & & 1.44 & 3.13 & 65.57 \\
\hline Being close to your suppliers & Resources & 0.777 & & & \\
\hline Easy access to raw material & Resources & 0.584 & & & \\
\hline Factor 8: Financial stimuli & & & 1.37 & 2.98 & 68.54 \\
\hline Access to local financial resources & Economy & 0.762 & & & \\
\hline Government subsidies & Incentives & 0.674 & & & \\
\hline Factor 9: Market expectation & & & 1.15 & 2.51 & 71.05 \\
\hline Purchasing power Dutch firms & Market & 0.768 & & & \\
\hline Market growth potential & Market & 0.568 & & & \\
\hline Factor 10: Push factors & & & 1.10 & 2.39 & 73.44 \\
\hline Saturated home market & Market & 0.823 & & & \\
\hline Factor 11: Regional cooperation & & & 1.03 & 2.23 & 75.67 \\
\hline Location within Benelux & Market & 0.846 & & & \\
\hline
\end{tabular}

The eleven factors may be summarised as economic and legal system, transportation and storage infrastructure, office infrastructure and staff, quality of labour + airport, customer base, accessibility, availability of inputs to production, financial stimuli, market expectation, push factors and regional cooperation. On both factors two and three infrastructural factors loaded. Surprisingly Schiphol Airport did not load with the other infrastructural factors, but with labour-related variables in factor four. Despite these irregularities, overall the factors make good intuitive and conceptual sense. 
We have tested the reliability of the scales resulting from the factor analysis by calculating the Cronbach's alpha-values. These values are presented in the tables in the appendix to this chapter (Appendix 5.1). For all 46 items used in testing the strength of the firm in doing business in the Netherlands, we find that Cronbach's alpha is acceptably high (0.94). The high value for the entire sample indicates that the items measure the same underlying construct suggesting that the data are uni-dimensional, all measuring locational determinants of FDI. When testing for the seven dimensions specified beforehand (market, infrastructure, resources, economy, barriers, incentives, and society) we find that the Cronbach's alphas are still acceptably high (ranging from $0.73-0.79$, with the exception of incentives $(0.56)$ and market size ${ }^{26}(0.58)$ for which the items could be improved). This result indicates that particularly for infrastructure, economy, natural and created resource endowments and society, the questionnaire items measure the underlying constructs quite well. The test of the reliability of the further breakdown into 11 underlying factors results in Cronbach's alphas ranging between $0.57-0.93$. With the exception of factor 7 (availability of inputs to production) and factor 9 (market expectation) the items measure the underlying constructs quite well.

Summarising the results, we find strong support for hypotheses 5 and 7. The favourable location of the Netherlands within Europe increases the attractiveness of the country as a base for foreign affiliates. Furthermore, these firms want to be close to key industry markets. In addition, the quality of the Dutch labourers and their language skills attract foreign MNEs to the Netherlands.

The results offer moderate support for hypothesis 8 but the overall effect of the stable economic climate strongly enhances when taking specific characteristics of the affiliate into account. The same is true for the importance of infrastructure (hypothesis 6) and government incentives (hypothesis 9). Although not important for the entire sample, they are for firms that export from their Dutch base, are regional headquarters for their parent, or have a non-European parent.

We find no support for the importance of available knowledge (part of hypothesis 7). Societal provisions turn out to be important only for firms that are regional headquarters for their parent (hypothesis 10). Trade regulations (hypothesis 11) and access to raw materials (part of hypothesis 7) matter for affiliates that export and for those that are regional headquarters. They do not affect the entire group.

\subsubsection{Overall results}

In this chapter we have analysed the influence of the $\mathrm{O}, \mathrm{I}$, and $\mathrm{L}$ advantages on the decision to establish an affiliate in the Netherlands. Table 5.11 gives an overview of the hypotheses and summarises the results of the analyses conducted in the previous sections.

\footnotetext{
${ }^{26}$ The market size group has a large number of items for which the item-to-total correlation is smaller than 0.30 . Splitting this group in subsets could improve the reliability of the measurements.
} 
The table also presents the results when controlling for characteristics of the firm, such as the location of the parent, size, age, and focus of its sales.

Table 5.11 Hypotheses tests

\begin{tabular}{|c|c|c|c|c|c|c|c|}
\hline & Hypothesis & ॠ & 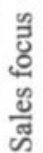 & 芯 号 & 홀 & $\stackrel{\infty}{<}$ & $\frac{\mathbb{N}}{\infty}$ \\
\hline 1 & $\begin{array}{l}\text { Asset-related ownership advantages (Oa) will positively } \\
\text { influence a foreign firm's decision to start activities in a host } \\
\text { economy }\end{array}$ & 1 & 4 & 4 & 4 & 5 & 5 \\
\hline 2 & $\begin{array}{l}\text { Transaction-specific ownership advantages (Ot) will positively } \\
\text { influence a foreign firm's decision to start activities in a host } \\
\text { economy }\end{array}$ & 1 & 4 & 4 & 4 & 4 & 5 \\
\hline 3 & $\begin{array}{l}\text { The unavailability of alternative modes - such as acquisition, } \\
\text { licensing, or sales via an agent - positively influences the } \\
\text { foreign firm's choice to start an affiliate in a host market }\end{array}$ & 3 & 5 & 5 & 5 & 5 & 5 \\
\hline 4 & $\begin{array}{l}\text { High costs of making and enforcing contracts negatively } \\
\text { influence a foreign firm's decision to start activities in a host } \\
\text { economy. }\end{array}$ & 3 & 5 & 5 & 5 & 5 & 5 \\
\hline 5 & $\begin{array}{l}\text { The location of a host market within a larger regional market } \\
\text { positively influences a foreign firm's decision to start activities } \\
\text { in a host economy. }\end{array}$ & 1 & 4 & 4 & 4 & 4 & 4 \\
\hline 6 & $\begin{array}{l}\text { Large infrastructural provisions positively influence a foreign } \\
\text { firm's decision to start activities in a host economy }\end{array}$ & 3 & 4 & 4 & 4 & 5 & 5 \\
\hline 7 & $\begin{array}{l}\text { Resource availability positively influences a foreign firm's } \\
\text { decision to start activities in a host economy. }\end{array}$ & 1 & 4 & 4 & 4 & 5 & 5 \\
\hline 8 & $\begin{array}{l}\text { A stable economic climate positively influences a foreign } \\
\text { firm's decision to start activities in a host economy }\end{array}$ & 2 & 4 & 4 & 4 & 5 & 5 \\
\hline 9 & $\begin{array}{l}\text { Government incentives positively influence a foreign firm's } \\
\text { decision to start activities in a host economy }\end{array}$ & 3 & 4 & 4 & 4 & 5 & 4 \\
\hline 10 & $\begin{array}{l}\text { Adequate societal provisions positively influence a foreign } \\
\text { firm's decision to start activities in a host economy }\end{array}$ & 3 & 5 & 5 & 4 & 5 & 5 \\
\hline 11 & $\begin{array}{l}\text { Existing trade regulations and efficient customs positively } \\
\text { influence a foreign firm's decision to start activities in a host } \\
\text { economy }\end{array}$ & 3 & 4 & 5 & 4 & 5 & 5 \\
\hline
\end{tabular}

$1=$ Strong support

2 = Moderate support

$3=$ Not confirmed by analyses

$4=$ Stronger effect when this characteristic of the affiliate is taken into account

$5=$ No difference between overall analysis and result for specific characteristic

\subsection{Discussion}

Our main objective in this chapter was to analyse the determinants of foreign establishments in the Dutch electronics industry within the OLI-framework of Dunning $(1988,1993,2000,2001)$. It is a first attempt to identify, classify, and explain the key country-specific locational determinants and firm-specific strengths of electronics investments by foreign firms in the Netherlands. Considering that the three groups of 
advantages are sequential, in this section we first discuss the ownership advantages that must be present before a firm considers international business activities. Then we analyse the reasons for internalisation of the activity within the hierarchy of the firm. Finally we discuss the most important location factors that explain the choice for the Netherlands.

\subsubsection{Ownership}

Regarding the ownership advantages, our results indicate that both $\mathrm{Oa}$ and Ot advantages explain the strength of the foreign affiliate in the Netherlands, confirming the general idea expressed in Dunning's Eclectic Paradigm (1988, 1993, 2000, 2001).

We find that the most important competitive strength of foreign establishments in the Dutch electronics industry consists of their marketing skills. This emphasis on marketing factors is not surprising, considering that firms in the consumer goods industries usually rely on local marketing know-how (Wilson, 1980). Furthermore, considering that 81 of the 86 firms in the sample indicate that sales are an important activity for their Dutch establishment, strong marketing skills are a necessity for success and survival.

In addition, most affiliates in our study strongly emphasise the importance of their knowledge of the Dutch market. Therefore our findings confirm a study by Chen (1983) that also indicates that familiarity with a host market is an important determinant of foreign investments. In addition, most managers put strong emphasis on tailoring their products to the European market, indicating that the de facto market size of the Netherlands should be understood to include the entire European continent and not just the Netherlands.

With respect to their products, the managers in our sample emphasise their superior technology combined with price competitiveness. Given that most of our affiliates are greenfield ventures, this result is not surprising. Wilson (1980) states that greenfield ventures are started by firms with distinct superior technologies. This is particularly relevant for high-tech industries such as electronics. The results of our present study confirm this statement.

Overall, the firm's contacts with local governments are not very important which is not surprising since previous research has shown that firms that possess a proprietary product or technology have bargaining power over the host government (Lecraw 1984) and therefore do not depend strongly on their government contacts.

When we consider the characteristics of the sample firms, small differences exist among the most important strengths. The largest differences can be found taking the home country and the sales destination into consideration. Firms with non-EU parents, those acting as regional headquarters, and those focussing their sales on Europe (and not just the Netherlands) put much more emphasis on economies of scale and scope in the production process and on products tailored to the European market than the other firms do. Given that regional headquarters have a strategic role within the MNE (Forsgren et al. 1995 ) this is not a surprising result. In addition, firms from outside the EU will rationalise 
their investments on the European continent in such a way that they gain from the common governance of geographically dispersed activities. This matches the stronger emphasis on the EU-location and infrastructure found in Section 5.6.2.

\subsubsection{Internalisation}

Regarding hypothesis three and four we find no confirmation. From Table 5.6 it is clear that all four alternative modes for FDI - licensing, exports, exports through an agent, or acquisitions - are not important for this sample of firms. Furthermore, the costs of making and enforcing contracts do not hinder any of the managers in this study either. We therefore find that even though alternative modes are available, the MNE still chooses to start a local affiliate in the Dutch market. Over 60 percent of the firms responding to the questionnaire entered the Dutch market with a wholly-owned subsidiary. Most foreign firms in the Netherlands therefore internalise the exploitation of their unique $\mathrm{O}$-advantages within the hierarchy of the firm. This allows them to control the quality of the product and service level and saves them the costs of searching and enforcing external relationships.

In this study we have limited the test of internalisation advantages to the availability of alternative modes of foreign involvement. However, a better understanding of internalisation advantages would require additional research to take the many dimensions of internalisation ${ }^{27}$ at the level of the MNE into account (see for instance Dunning and Kundu 1995, O'Gorman and McTiernan 2000). Future research could also compare the mode of the Dutch establishment with the modes used in other foreign countries where the MNE operates. This would allow researchers to determine whether MNEs behave differently in different markets and to relate these differences to characteristics of these markets.

\subsubsection{Location}

Regarding the locational determinants, our results indicate that our sample firms were attracted to the Netherlands by a selection of the possible determinants mentioned in Dunning's Eclectic Paradigm (1988, 1993, 2000, 2001). In general, our sample firms are motivated by the need to be close to their customer, the market growth potential, the multi-lingual population, the size of the Dutch market and the purchasing power of the Dutch consumers, and the need to be close to key industry markets. We therefore find that many foreign establishments in the Dutch electronics industry are market-seeking investments. This result confirms previous studies that also indicate the importance of market potential (such as Terpstra and Yu 1988, Dunning and Kundu 1995). However, in our case the market should be interpreted as comprising not only the Netherlands, but the

${ }^{27}$ Such as ensuring adequate quality control, avoiding the risk of dissipation of knowledge, avoidance of property right enforcement costs (Tatoglu and Glaister, 1998a). 
entire European continent. This is an encouraging result for other small economies. Despite their small market size, their overall attractiveness increases when they are part of a larger regional trade block. If foreign firms can reach these other markets from their base in the small economy, the small economy can still benefit from the additional employment opportunities, local linkages, capital inflow, and knowledge spillovers even though the goods are exported.

Particularly larger firms consider the Netherlands to be a gateway to Europe. Firms employing up to ten people seem more focused on the Netherlands and value the Dutch market size and purchasing power of Dutch consumers and firms much more than large firms. Their limited size restricts them to serving just the Dutch market. They lack the critical mass needed to reach and supply customers in Europe. Larger affiliates, however, emphasise the proximity to the EU market and the Dutch membership to the EU. Chandprapalert (2000) finds a similar result for Thailand that is used by foreign investors as a hub to Myanmar and Vietnam.

Likewise, we find that firms with non-EU parents also put much more emphasis on the location within the Benelux, the easy access to Europe, the EU-membership of the Netherlands, and Schiphol airport than firms whose parents are located within the $\mathrm{EU}^{28}$. This result indicates that these non-EU firms are inclined to serve the entire European market and not just the Netherlands. They choose the Netherlands as a base for their European activities.

Investments in the Dutch market are also motivated by resource-seeking arguments. Labour is the most important resource. Many affiliates highly value the productivity of the Dutch labourers and their language skills. This result indicates that particularly the 'created/engineered' factor endowments are an important part of the attractiveness of the Netherlands. Foreign affiliates are not attracted to the Netherlands because of the access to raw materials. This is not surprising considering the high-tech nature of the industry and the limited availability of raw materials in the Netherlands (natural gas excluded). The access to (public) knowledge has not motivated our sample firms to start activities in the Netherlands either. It is likely that these firms are not looking for basic knowledge, but rather value applied knowledge more, given that they do want to be close to key industry markets. Again, this is an encouraging result for other small economies. As discussed in Chapter one, most small economies are less diversified in raw materials and natural resources or lack the capital to explore them. The Dutch experience signals that investments in human capital can result in an increasing attractiveness as well. Foreign firms' entry can be motivated by the need to exploit the local created/engineered factor endowments in the small economy.

Contrary to our expectations, infrastructural provisions (such as waterways, motorways, railways, and harbours) are no decisive factors that attract foreign electronics firms to the Netherlands. When considering the characteristics of the individual affiliate, we find one

${ }^{28}$ They can, in most cases, reach the European market just as easily from the home country as from the Netherlands. 
important exception. Firms that mainly or only export from their Dutch location put strong emphasis on infrastructural aspects. They value Schiphol Airport, the motorway network, truck transportation, and office space significantly more than the other affiliates. Overall, these exporting firms are most outspoken on their reasons for locating in the Netherlands. They also emphasise factors related to the European market, the availability of high productivity, multi-lingual labour, technical and managerial skills, and the tax regime and customs policies.

Our research indicates an interesting difference between firms that started their activities before and those that started after the acceptance of the Single European Act in 1987. Firms that started activities after 1987 ('younger' firms) value being close to key industrial markets and the multi-lingual population significantly more than the 'older' firms. On the other hand we find that 'older' firms put much more emphasis on the Dutch market size and the purchasing power of Dutch consumers than 'younger' firms. This result might indicate that newer establishments have a more European orientation which makes sense considering that the increasing integration in the European market and the reduction in trade barriers have facilitated a restructuring of overall MNE activity in Europe. New affiliates will choose a location that facilitates an easy access to the entire European market and organise all their activities in a way that achieves overall efficiency for the MNE. The favourable location of the Netherlands within the core of the European Union and the ease of access to the other European economies encourages foreign firms to locate in the Netherlands. Affiliates established before the EU integration are more likely to be of a traditional market-seeking type, focusing on supplying the Dutch market only.

Contrary to the general perception, we find that the firms in our sample are not attracted by government incentives. Other factors, like the market size and the access to the European market, are much more important. The lack of importance of the incentives could result from the fact that we have not distinguished among the possible incentives (see Rolfe et al. (1993) for a full list of factors). For a better understanding of this phenomenon future research could target the individual incentives.

\subsubsection{Limitations}

The analyses in this chapter have some limitations. Restricting ourselves to one particular sector reduces the generalisability of the results. However, given that empirical investigations of the motivations to establish in the Netherlands are lacking completely, our results offer a good starting point for further studies. The generalisability of the results is also limited by the small sample. However, the results indicate some clear and logical differences between the groups of affiliates when their characteristics are taken into account. The results therefore help to understand the different OLI determinants for these groups of foreign firms operating in the Netherlands. Furthermore, given the exploratory nature of the study, the analyses are conducted using univariate statistical 
techniques. However, more sophisticated econometric tools exist. Therefore, considerable scope exists for future research to consider multi-variate analyses to investigate the significance of the host country locational factors and the firm-specific competitive strengths and their interactions.

In this chapter, the focus is on the (potential) attractiveness of the Netherlands as a location for foreign affiliates, ignoring potential problems. However, in the questionnaire, firms were asked which problems they experienced while doing business in the Netherlands. Overall, the Netherlands turns out to be an attractive location for foreign investors. Only two main problems stand out: increasing traffic congestion and the scarcity of qualified high skilled labour. The full analysis of their responses is given in a separate appendix (Appendix D).

A final limitation concerns the exploratory character of this study. Given that no other extensive questionnaire study concerning the OLI paradigm so far has been conducted and published, this study is a first attempt to formally test the OLI framework for a small country. The reliability tests indicate that the questionnaire designed for this study serves its purpose fairly well, though some improvements can be made, particularly concerning the market-size items and the internalisation factors. Furthermore, the questionnaire has targeted only the electronics industry and can be repeated for other industries to extend our knowledge of the determinants of inward foreign direct investment.

\subsection{Conclusion}

The eclectic paradigm of international production (Dunning 1980, 1988a, 1995, 2000, 2001 ) is currently the most widely accepted theoretical framework to analyse foreign activities of multinational enterprises. The eclectic paradigm states that the extent, geography, and industrial composition of foreign production undertaken by MNEs are determined by the interaction of three sets of interdependent variables: ownership (O), location (L), and internalisation (I) advantages. This chapter aimed to examine the determinants of foreign direct investment in the Dutch electronics industry within the OLI-framework.

We find that the foreign affiliates that are located in the Netherlands possess both $\mathrm{Oa}$ and Ot advantages that allow them to operate in a market that is foreign to them. They emphasise both their marketing skills and the international experience of their parent as important strengths that help them operate in the Dutch market. Although alternative modes are available, they still chose to internalise the exploitation of their ownership advantages within the hierarchy of the firm. We find that the most important locational determinants include the need to be close to the consumer and the market growth potential. The analyses indicate that most managers put strong emphasis on tailoring their products to the European market, indicating that the de facto market size of the Netherlands should be understood to include the entire European continent and not just the Netherlands. Particularly those firms that started their Dutch operations after the 
acceptance of the Single European Act in 1987 chose the Netherlands as part of their overall strategy to serve the entire European Union market most efficiently. The findings of this study have important managerial and policy implications. The Dutch government can target its investment policies towards the strengthening of the infrastructure, the ease of access to the European Union economies, sustainable growth, purchasing power of the Dutch consumers, and high-quality labour. Furthermore, the results indicate that it makes sense to distinguish between the home countries of the investors and target policies accordingly. One should keep in mind, however, that the results of this current study do not present a recipe for success. Sources of competitive advantage are by definition not easily identified or imitated, nor are they static over time. Knowledge of these factors is only a first indicator of potential success. The application or improvement of these factors within the affiliate is the real challenge.

We could see that the largest differences in locational determinants exist between firms that focus their sales on the Dutch market only and firms that supply a broader (European) market. This may be the result of differences in the characteristics of the affiliates, influencing their behaviour in foreign markets. We therefore want to investigate the factors that determine the sales focus of the electronics affiliates more thoroughly. This analysis is conducted in Chapter six. 


\section{Appendix 5.1 Reliability analyses}

In this appendix we report the results of the reliability analysis regarding the items used in the questionnaire survey to test the OLI paradigm. Reliability is the degree to which measures are free from error and yield consistent results. There are three basic methods to assess reliability: 1) test-retest, 2) internal consistency, and 3) other forms. We here rely on Cronbach's alpha values to test the internal consistency reliability in the survey. It is a generally accepted method for data that are measured on a Likert scale.

\section{STRENGTH}

Table 5A.1 Assessment of reliability: Firm's strength Total sample

\begin{tabular}{|l|r|r|r|}
\hline Factors & $\begin{array}{c}\text { Item-to-total } \\
\text { correlations }\end{array}$ & Cronbach's alpha & N \\
\hline Total sample (17 items) & & 0.86 & 81 \\
\hline
\end{tabular}

Table 5A.2 Assessment of reliability: Firm's strength

Specified constructs ( $\mathrm{Oa}$ and $\mathrm{Ot}$ )

\begin{tabular}{|l|r|r|r|}
\hline Factors & $\begin{array}{c}\text { Item-to-total } \\
\text { correlations }\end{array}$ & Cronbach's alpha & N \\
\hline Oa & 0.3260 & 0.75 & 82 \\
Marketing skills & 0.2981 & & \\
Good distribution channels & 0.5546 & & \\
Superior production technology & 0.5702 & \\
Price competitiveness & 0.3671 & \\
Products tailored to the European market & 0.4670 & \\
Product niche market & 0.5931 & \\
Economies of scale in production & 0.4066 & \\
Products tailored to the Dutch market & 0.3423 & \\
Lack of competition for product or service & & \\
\hline Ot & 0.5786 & \\
Economies of scope in production & 0.3911 & \\
Dedicated suppliers & 0.5212 & & \\
International experience of parent & 0.3772 & & \\
Knowledge of the Dutch market & 0.3959 & & \\
Independence of headquarters & 0.4220 & & \\
Headquarter support & 0.4270 & & \\
Ability to raise capital at preferential rates & 0.5387 & & \\
Local government contacts & & \\
\hline
\end{tabular}


Table 5A.3 Assessment of reliability: Firm's strength

Factor analysis

\begin{tabular}{|c|c|c|c|}
\hline Factors & $\begin{array}{c}\text { Item-to-total } \\
\text { correlations }\end{array}$ & Cronbach's alpha & $\mathrm{N}$ \\
\hline Factor 1: Production-technology factors & & 0.82 & 83 \\
\hline Products tailored to the European market & 0.4791 & & \\
\hline Economies of scale in production & 0.7436 & & \\
\hline Superior product technology & 0.5943 & & \\
\hline Economies of scope in production & 0.7460 & & \\
\hline Price competitiveness & 0.5289 & & \\
\hline Factor 2: Headquarter characteristics & & 0.65 & 85 \\
\hline Independence of headquarters & 0.4058 & & \\
\hline International experience of parent & 0.5161 & & \\
\hline Headquarter support & 0.4562 & & \\
\hline Factor 3: Marketing factors & & 0.44 & 85 \\
\hline Knowledge of the Dutch market & 0.2542 & & \\
\hline Good distribution channels & 0.3215 & & \\
\hline Marketing skills & 0.2604 & & \\
\hline Factor 4: Strategic product positioning & & 0.57 & 83 \\
\hline Product market niche & 0.4031 & & \\
\hline Lack of competitors for product or service & 0.4031 & & \\
\hline Factor 5: Institutional factors & & 0.67 & 85 \\
\hline Ability to raise capital at preferential rates & 0.5023 & & \\
\hline Local government contacts & 0.5023 & & \\
\hline
\end{tabular}

Principle Components Factor analysis with varimax rotation 


\section{INTERNALISATION}

Table 5A.4 Assessment of reliability: Internalisation

Total sample

\begin{tabular}{|l|r|r|r|}
\hline Factors & $\begin{array}{c}\text { Item-to-total } \\
\text { correlations }\end{array}$ & Cronbach's alpha & N \\
\hline Total sample (5 items) & & 0.70 & 85 \\
\hline
\end{tabular}

Table 5A.5 Assessment of reliability: Internalisation

Factor analysis

\begin{tabular}{|c|c|c|c|}
\hline Factors & $\begin{array}{l}\text { Item-to-total } \\
\text { correlations }\end{array}$ & Cronbach's alpha & $\mathrm{N}$ \\
\hline Factor 1: Costs of conducting activities & & 0.58 & 85 \\
\hline High costs of making and enforcing contracts & 0.4781 & & \\
\hline Exports to the Netherlands too expensive & 0.4684 & & \\
\hline Acquisition opportunity & 0.2641 & & \\
\hline Factor 2: Control over activities & & 0.80 & 86 \\
\hline No good licensing partner available & 0.6803 & & \\
\hline No good agents available & 0.6803 & & \\
\hline
\end{tabular}




\section{LOCATION}

Table 5A.6 Assessment of reliability: Location

Total sample

\begin{tabular}{|l|r|r|r|}
\hline Factors & $\begin{array}{c}\text { Item-to-total } \\
\text { correlations }\end{array}$ & Cronbach's alpha & N \\
\hline Total sample (46 items) & & 0.94 & 83 \\
\hline
\end{tabular}

Table 5A.7 Assessment of reliability:Location

7 specified groups of variables

\begin{tabular}{|c|c|c|c|}
\hline Factors & $\begin{array}{l}\text { Item-to-total } \\
\text { correlations }\end{array}$ & Cronbach's alpha & $\mathrm{N}$ \\
\hline Natural and created resource endowments & & 0.85 & 84 \\
\hline Multi-lingual population & 0.7388 & & \\
\hline Being close to key industry markets & 0.2597 & & \\
\hline Qualified and experienced technical staff & 0.6740 & & \\
\hline Availability of management skills & 0.7861 & & \\
\hline High labour productivity & 0.7467 & & \\
\hline Availability of ICT resources & 0.6413 & & \\
\hline Lower labour costs & 0.5510 & & \\
\hline Proximity to important research institutes and & & & \\
\hline universities & 0.4630 & & \\
\hline Being close to your supplier & 0.3166 & & \\
\hline Easy access to raw materials & 0.4084 & & \\
\hline Economic factors & & 0.87 & 86 \\
\hline Regional economic growth & 0.4513 & & \\
\hline Economic and political stability & 0.7273 & & \\
\hline Dutch membership of the European Union & 0.7779 & & \\
\hline Open investment climate & 0.8508 & & \\
\hline Stable exchange rates & 0.7803 & & \\
\hline Access to local financial resources & 0.4620 & & \\
\hline Incentives & & 0.56 & 86 \\
\hline Tax regime & 0.3933 & & \\
\hline Government subsidies & 0.3933 & & \\
\hline Society & & 0.77 & 86 \\
\hline Comprehensive legal system & 0.6199 & & \\
\hline Efficient bureaucracy & 0.6199 & & \\
\hline
\end{tabular}


Table 5A.7 Assessment of reliability: Location (continued)

\begin{tabular}{|c|c|c|c|}
\hline Factors & $\begin{array}{l}\text { Item-to-total } \\
\text { correlations }\end{array}$ & Cronbach's alpha & $\mathrm{N}$ \\
\hline Artificial barriers & & 0.73 & 86 \\
\hline Favourable customs policy & 0.5807 & & \\
\hline Fear of import restrictions due to European & & & \\
\hline Union & 0.5807 & & \\
\hline Infrastructure & & 0.93 & 86 \\
\hline Schiphol airport & 0.5885 & & \\
\hline Availability of office space & 0.7301 & & \\
\hline Motorway network & 0.7408 & & \\
\hline Availability of truck transportation & 0.7672 & & \\
\hline Price of office space & 0.7999 & & \\
\hline Availability of warehousing facilities & 0.7386 & & \\
\hline Availability of industrial parks & 0.6658 & & \\
\hline Price of road transportation & 0.7808 & & \\
\hline Price of warehousing facilities & 0.7697 & & \\
\hline Harbours & 0.6238 & & \\
\hline Railways & 0.6160 & & \\
\hline Waterways & 0.5599 & & \\
\hline Market size & & 0.58 & 84 \\
\hline Being close to your customer & 0.1899 & & \\
\hline Market growth potential & 0.2360 & & \\
\hline Following client & 0.5529 & & \\
\hline Dutch market size and purchasing power Dutch & & & \\
\hline consumers & 0.3786 & & \\
\hline Location within Benelux & 0.1353 & & \\
\hline Easy access to the European market & -0.0107 & & \\
\hline Purchasing power of Dutch firms & 0.3371 & & \\
\hline Following competition & 0.3628 & & \\
\hline Central location in Europe & -0.1167 & & \\
\hline Potential client wanted a Dutch establishment & 0.4506 & & \\
\hline Diversification of activities & 0.3276 & & \\
\hline Saturated home market & 0.2660 & & \\
\hline
\end{tabular}


Table 5A.8 Assessment of reliability: Locational determinants

Factor analysis

\begin{tabular}{|c|c|c|c|}
\hline Factors & $\begin{array}{c}\text { Item-tot-total } \\
\text { correlations }\end{array}$ & Cronbach alpha & $\mathrm{N}$ \\
\hline $\begin{array}{l}\text { Factor 1: Economic and legal system } \\
\text { Dutch membership of the European Union } \\
\text { Fear of import restrictions due to European } \\
\text { Union } \\
\text { Regional economic growth } \\
\text { Stable exchange rates } \\
\text { Open investment climate } \\
\text { Comprehensive legal system } \\
\text { Economic and political stability } \\
\text { Efficient bureaucracy } \\
\text { Tax regime } \\
\text { Favourable customs policy }\end{array}$ & $\begin{array}{l}0.6346 \\
0.4122 \\
0.8117 \\
0.8509 \\
0.7691 \\
0.7773 \\
0.7777 \\
0.6615 \\
0.8250\end{array}$ & 0.93 & 86 \\
\hline $\begin{array}{l}\text { Factor 2: Transportation and storage } \\
\text { infrastructure } \\
\text { Price of road transportation } \\
\text { Availability of truck transportation } \\
\text { Availability of warehousing } \\
\text { Price of warehousing } \\
\text { Railways } \\
\text { Harbours } \\
\text { Waterways }\end{array}$ & $\begin{array}{l}0.8093 \\
0.7747 \\
0.7262 \\
0.7637 \\
0.6452 \\
0.6614 \\
0.6359\end{array}$ & 0.90 & 86 \\
\hline $\begin{array}{l}\text { Factor 3: Office infrastructure and staff } \\
\text { Availability of office space } \\
\text { Qualified and experienced technical staff } \\
\text { Price of office space } \\
\text { Availability of industrial parks } \\
\text { Motorway network } \\
\text { Availability of management skills } \\
\text { Availability of ICT resources }\end{array}$ & $\begin{array}{l}0.8786 \\
0.7294 \\
0.7699 \\
0.7761 \\
0.6982 \\
0.7699 \\
0.7174 \\
\end{array}$ & 0.93 & 86 \\
\hline $\begin{array}{l}\text { Factor 4: International orientation and } \\
\text { productivity } \\
\text { High labour productivity } \\
\text { Lower labour costs } \\
\text { Schiphol airport } \\
\text { Multi-lingual population }\end{array}$ & $\begin{array}{l}0.8348 \\
0.6746 \\
0.7283 \\
0.8079\end{array}$ & 0.89 & 85 \\
\hline
\end{tabular}


Table 5A.8 Assessment of reliability: Locational determinants (continued)

\begin{tabular}{|l|r|r|r|}
\hline Factors & $\begin{array}{c}\text { Item-tot-total } \\
\text { correlations }\end{array}$ & Cronbach alpha & N \\
\hline Factor 5: Customer base & 0.4692 & 0.72 & 84 \\
Potential client wanted a Dutch establishment & & & \\
Dutch market size and purchasing power Dutch & & & \\
consumer & 0.5593 & & \\
Following client & 0.6124 & & 85 \\
\hline Factor 6: Accessibility & 0.8727 & & \\
Easy access to European market & 0.8707 & & \\
Central location in Europe & & & \\
\hline Factor 7: Availability of inputs to production & 0.4023 & & \\
Being close to your suppliers & 0.4023 & & \\
Easy access to raw material & & & \\
\hline Factor 8: Financial stimuli & 0.4206 & & \\
Access to local financial resources & 0.4206 & & \\
Government subsidies & & & \\
\hline Factor 9: Market expectation & 0.3988 & & \\
Purchasing power Dutch firms & 0.3988 & & \\
Market growth potential & & & \\
\hline Factor 10: Push factors & & & \\
Saturated home market & & & \\
\hline Factor 11: Regional cooperation & & & \\
Location within Benelux & & & \\
\hline
\end{tabular}




\section{Chapter six}

\section{DETERMINANTS OF THE SALES FocUS OF FOREIGN AFFILIATES IN THE NETHERLANDS}

\subsection{Introduction}

The developments in the international economic environment (as discussed in Chapter two) have induced many multinational enterprises (MNEs) to adopt new approaches to competing worldwide, with these changes having major implications for the roles played by their affiliates in individual host countries (Papanastassiou and Pearce 1994). As competition in many industries becomes increasingly global, MNEs have found that import-substituting affiliates - focussing on the supply of national markets - have become less viable. Instead, in most industrial sectors (especially in electronics and pharmaceuticals) marketing and sales activities are now located in one particular host country to serve a broader (for instance European) market (Calliano and Carpano 2000). We have found strong evidence for this fact in the analyses in Chapter 5. MNEs that want to stay competitive in the globalising markets have to make the most effective use of their worldwide assets.

To broaden the base of their innovative capabilities, MNEs therefore want to tap into the creative resources in a wide range of locations. Ownership-advantages are no longer solely developed at the corporate headquarters and leveraged abroad to a network of affiliates. Instead, as these affiliates grow in size and develop their own unique resources, increasingly they themselves become important sources of competitive advantage for the MNE. Affiliates should therefore no longer just be seen as pipelines to move products. Their own special strengths can help build competitive advantages for the entire MNE (Bartlett and Ghoshal 1986). The role of the affiliate in a host market has therefore frequently shifted from import-substitution towards an export-oriented, strategic position in the MNE group's global network (Papanastassiou and Pearce 1994, Birkinshaw and Hood 1998). Some affiliates even develop into centres of excellence, controlling vital resources that other parts of the MNE depend upon (Holm and Pedersen 2000).

The changing role of foreign affiliates creates interesting opportunities for small economies to attract FDI. First of all, they can increase their attractiveness as a location for foreign affiliates by concentrating their policy efforts on creating and sustaining specific innovative strengths that MNEs would like to tap into. Secondly, if the affiliate no longer only supplies the host market (which in these economies is usually to small to justify the investment) but instead targets a broader market with its sales, small economies could benefit from their strategic position within, and the quality of the access to a large(r) regional market. The establishment of an affiliate in a small economy could 
then be beneficial for both the affiliate and the small economy. The affiliate can achieve the necessary output volume to achieve the economies of scale needed for efficient production. The small economy will benefit from the additional labour, the skills spillovers, and the capital flows, even though (a part of) the goods are exported.

It is generally assumed that the Netherlands is among those small economies that attract FDI due to their favourable geographic location. As the Netherlands was among those countries initiating the European customs union in 1957 (see Chapter two), foreign affiliates located there have benefited from the process of increasing economic and political integration. Strategically located within the European Union and at the North Sea, MNEs can use their Dutch establishment to supply not only the (relatively small) Dutch market with their sales, but also other (European) markets. The results of the analyses of the motivations and locational determinants of FDI in the Dutch electronics industry (in Chapter five) confirm this assumption. We find that half of the firms participating in the survey sell at least $10 \%$ outside the Dutch market.

In this chapter we extend the analyses of Chapter five. The purpose of this present chapter is to explore the determinants of the behaviour of the foreign affiliate ${ }^{1}$. We therefore take a closer look at the role of the affiliate in the host market. The main focus in this chapter is on identifying the factors that determine the sales focus of the affiliate (do they supply only the host market or do they target a broader regional market?). A theoretical framework to analyse these determinants is still lacking. The present analysis is therefore exploratory in nature.

This chapter is structured as follows. Section two provides a background for the hypotheses. A starting point for this study can be found in the expanding body of literature that discusses the role of the affiliate in the host market. The discussion of this literature is followed by a description of six hypotheses that stipulate the relationship between the characteristics of the affiliate and its sales focus. Given the specifics of the data, we use bi- and multinomial logit analyses to test the model. This methodology is discussed in Section three. Section four then discusses the actual data used to test the conceptual model resulting from the hypotheses. Sections five and six present and discuss the results of the exploratory analyses. Finally, we briefly discuss some of the major conclusions from this research in Section seven.

\subsection{Conceptual framework and hypotheses}

For an exploratory study it is important to first discuss its major subjects - here the role and activities of foreign affiliates in a host market - before presenting elements of theory development, hypotheses, and operational measures. The body of literature focusing on

\footnotetext{
${ }^{1}$ Most research of multinational establishment behaviour concentrates on the determinants of the choice for a particular entry mode (see f.e. Gatignon and Anderson 1988, Kogut and Singh 1988, GomesCasseres 1989, 1990, Bell 1996). Given that so much research has considered this aspect of MNE behaviour already, that is not the focus in this present study.
} 
the role of the affiliate in a host market is growing. Several typologies currently exist that classify these roles (for an overview see Birkinshaw and Morrison 1995, Taggart 1997a, and Harzing 2000). Generally, the affiliates' roles vary according to such contingencies as the local (resource) environment, product mandates, the structural context imposed by the parent, and the entrepreneurial capacity of subsidiary management (Forsgren et al. 1999, Birkinshaw and Hood 2000). Most classifications are complex, multi-dimensional frameworks that are difficult to validate empirically.

In this chapter, the focus is on the determinants of the sales activities of the affiliate. The work of White and Poynter (1984) therefore fits best with our purpose. They classify the roles of the affiliate using three dimensions: market scope, product scope, and value added scope. Market scope defines the geographical spread of markets served by the affiliate. Product scope is a measure of the affiliate's breadth of product line compared to the corresponding division of the parent company. Value-added scope is a measure of the range of ways in which the affiliate can add value to its output.

Following Taggart (1997b), for our affiliates we simplify this complex classification to two dimensions: value-added scope (what to do) and market scope (where to sell). The value-added scope of an affiliate's activities indicates the number of stages in the valueadded chain that are conducted at the site of the affiliate in the host economy. We distinguish five main activities: marketing and sales, manufacturing, research and development (R\&D), after sales services, and regional headquarters' functions. Affiliates conducting only up to three of those activities are classified as having a limited scope, those with four or more as having a broad value-added scope.

The market scope relates to the target region(s) for the affiliate's sales. Similar to the analyses in Chapter 5, two types of foci are distinguished. First of all, a local focus, covering those affiliates that focus mostly or completely ( $>90$ percent) on the host market. Secondly, a foreign focus, for affiliates that supply both the host market and other markets from their local establishment. Within this last group, two types are distinguished: those that have a mixed focus (supplying both the host and foreign markets) and those that have an export focus (and have over 90 percent of their sales outside the host market). Figure 6.1 illustrates the classification of affiliates according to these two scales.

Based on this classification four types of affiliates are distinguished. First, the affiliates in quadrant $\mathrm{A}$ that undertake one single or very few value adding activities in the host country (usually marketing and sales) and limit their sales to the host market. Overall they do not contribute anything unique to the MNEs' assets and are easily substitutable by activities in other locations (Narula 2001). These affiliates resemble the local marketing and sales satellites identified by Papanastassiou and Pearce (1994), Pearce and Tavares (1998), and Narula (2001).

Quadrant B covers the affiliates that have a broader value-added scope but still a limited geographic focus. They operate in a particular country only to supply that market with locally produced goods that have already been successfully innovated elsewhere. These 
affiliates resemble the (truncated $\left.{ }^{2}\right)$ miniature $^{3}$ replicas $^{4}$ identified by White and Poynter (1984) and Pearce and Tavares (1998).

Quadrant C identifies all those affiliates that combine a limited value-added scope with a foreign market scope. These export platforms focus on the specialised production of a very limited part of the established product range, perhaps even selected component parts of a separate stage in a vertically integrated production process (Papanastassiou and Pearce 1994). These activities can be carried out at an efficient scale because their market is regional or worldwide and also consists of considerable intra-group trade. The lowering of trade barriers (for instance in the European Union) has facilitated the creation of these export platforms.

All affiliates that combine a broad value-added scope with a foreign market scope are found in quadrant $\mathrm{D}$. These affiliates resemble the regional or world product mandate hubs of Papanastassiou and Pearce (1994). They have a mandate from their parents to create a distinctive new product and take responsibility for its further competitive evolution, its production, and its marketing in a regional or world market. In some cases, it might even be so that these affiliates have specialised capabilities on which the rest of the MNE is dependent (Birkinshaw and Hood 1998). The affiliate can respond to and take advantage of the distinctive locational advantages in their host market. Furthermore, it can capture the benefits of scale and learning from which it gets and sustains its competitive advantage (Bartlett and Ghoshal 1986).

Figure 6.1 Classification of affiliate activities

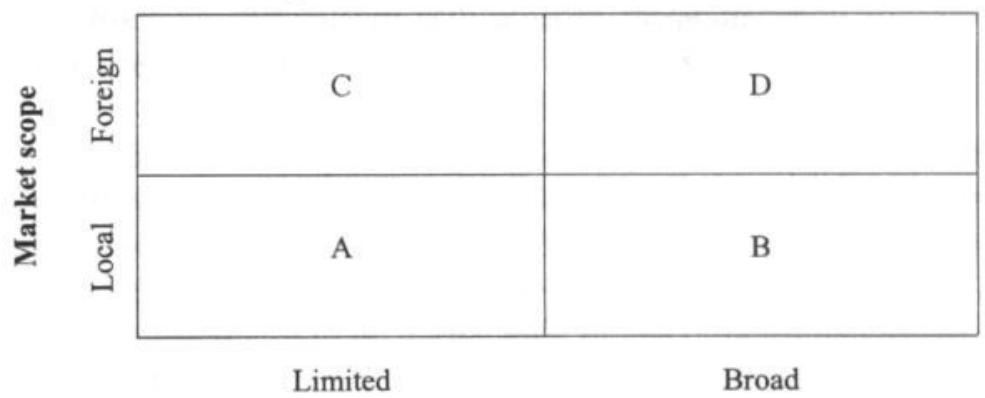

Value-added scope

Taggart (1997b) has tested which marketing, manufacturing, and technology variables can be used to classify subsidiary strategy in his reduced White and Poynter model. His

\footnotetext{
${ }^{2}$ They are considered truncated replicas when they lack important functions such as R\&D.

${ }^{3}$ They are considered miniature when their scale is smaller than that at the home country. This smaller scale frequently results in inefficiencies.

${ }^{4}$ The affiliate is a replica in the sense that it produces and sells in its host-country market most of the parent's products thereby reproducing the parent's behaviour (Papanastassiou and Pearce 1994).
} 
focus is on the responsibilities and authorities of the affiliate ${ }^{5}$. He ignores factors such as the location of the parent, the size and age of the affiliate, and the overall strategic choices of the parent. These factors and their possible influence on the sales focus of the affiliate therefore are the topic of this present study.

Prior work has shown that the size of the affiliate influences its strategy and market focus (Taggart 1996). Larger firms demonstrate a higher level of strategic complexity than smaller ones. We therefore expect that larger firms are better equipped to be export platforms or regional product mandates than smaller ones. The latter are more likely to be marketing and sales satellites or miniature replicas. We thus expect that affiliate size will influence the market scope. To supply both local and foreign markets from an establishment in a host country involves intensive monitoring of trends all over the region and perhaps even the world, particularly if the affiliate produces a specialised range of products and is not just a replica of the parent. This can only be achieved if enough human resources are present within the firm. Furthermore, offering after-sales services in more than one market also takes up more human resources than focusing on local sales only would. Affiliates with higher employment levels will therefore be more equipped to serve foreign markets from a host location than smaller ones. We thus suggest the following hypothesis:

\section{H1: A larger size of the foreign affiliate positively influences the affiliate's sales outside the host market}

Evidently, there is a development process that subsidiaries go through over time, in which they gradually build up resources, take on more responsibilities, and build up their credibility within the corporation (Birkinshaw and Fry 1998) ${ }^{6}$. This process could influence the role of the affiliate. It would be possible for older affiliates to expand their activities over time, taking new initiatives, and exploring other markets than their host country resulting in a broader market scope. On the other hand, if the affiliate has been established in the host market at a more recent date, it is more likely to be influenced by the trends of globalisation. Due to this rapid process, MNE activities have been rationalised, resulting in specialised affiliates that supply many markets (Calliano and Carpano 2000). Considering that the process of globalisation has resulted in rapidly expanding FDI flows and many new foreign establishments in the last two decades (as could be seen for the Netherlands in Chapter 2), the effect on sales of rationalisation due to globalisation will be larger than the effect of gradual learning within the (older) affiliate. Therefore we expect that younger affiliates will have a foreign market scope, while the older affiliates will be more locally-oriented.

\footnotetext{
${ }^{5}$ Taggart (1997b) finds that marketing factors (such as decisions about market priorities, market and customer needs, and location of customers) are the most important variables influencing the strategic role of the affiliate in a host market.

${ }^{6}$ Alternatively, if unsuccessful, the affiliate withdraws from the market or looks for a merger partner.
} 
H2: The age of the foreign affiliate negatively influences the affiliate's sales outside the host market

The sales focus of foreign affiliates is also influenced by the strategic role assigned to the affiliate by the parent. Originally, the headquarters were seen as the unit responsible for strategic decisions and monitoring the performance of the divisions (Birkinshaw and Morrison 1995). Centralising these facets of doing business would result in economising on coordination costs, the most efficient use of critical scarce resources, and a minimisation of opportunistic behaviour of divisional managers. However, Pralahad and Doz (1981) were among the first to recognise the inability of top management to fully understand the complexities of the various subsidiaries and peripheral operations. They emphasise the need to shift some of the headquarter tasks to local affiliates, allowing them responsibility for local issues. They confirm Schollhammer (1971) who indicated that the corporate headquarters should minimise the interference with the activities of the local affiliates. Its proper role would be to determine the overall corporate objectives and leave the affiliate's managers free to determine the necessary actions. When the affiliate is given the role of a regional headquarters, it is given authority to coordinate and supervise activities in a specific geographical area. This delegation of responsibilities can result in a concentration of all local and foreign sales activities at the regional headquarters as well, resulting in a foreign market focus. We therefore suggest the following hypothesis:

H3: A foreign affiliate's status as a regional headquarters for its parent positively influences the affiliate's sales outside the host market

Fourth, we expect affiliates with parent firms that are located in relative close distance to the host market to behave differently from affiliates whose parent firms are located at a further distance ${ }^{7}$. For the Netherlands in particular, we expect European firms with Dutch establishments to be more focused on the Dutch market only, while firms from outside the EU will use the Netherlands as an export base. Given the relatively small distances on the European continent, the parent located in the EU can supply other markets from the headquarters or from other production locations in the EU-countries. Their local affiliates will then most likely behave as marketing and sales satellites in the host market.

Firms from outside the EU, on the other hand, are expected to use the Netherlands as an export platform or stepping stone for Europe, partly due to rationalisation following the increased regional integration at the EU-level (Dunning 1993). Affiliates in countries inside the EU have easier access to a larger market and trade flows and factor movements are liberalised. It is therefore expected that MNEs from outside Europe specialise their affiliate's activities (giving the local affiliate a regional product mandate and allowing the

${ }^{7}$ Chapter 4 already illustrated that the establishment pattern differs between European affiliates and US or Japanese affiliates. We now focus on the sales activities developed at those establishments. 
transfer of intermediate or final goods to other markets). This results in an export focus for the local affiliate. We therefore suggest the following hypothesis:

H4: Foreign affiliates whose parents are located at close proximity to the host country will be more focussed on the host market only than affiliates whose parents are located further away

We expect that the sales focus is also influenced by the activities conducted at the local affiliate. Several scholars have proposed that each affiliate operates in its own unique environment (consisting of consumers, suppliers, competitors, and government bodies), which constrains or determines the activities of that affiliate (Ghoshal and Bartlett 1990, Rosenzweig and Singh 1991). For many affiliates operating in small economies, this environment is characterised by a limited number of consumers. This small market generally does not allow local manufacturing activities. MNEs that start an affiliate in these small markets will be inclined to limit its role to marketing and sales.

If the affiliate does develop local production facilities, in order to achieve the necessary economies of scale, it needs to expand its market scope to include other markets than just the host country's. These affiliates then use the local establishment as an export platform or develop into regional or global product mandates. We therefore suggest the following hypothesis:

H5: Foreign affiliates' host country manufacturing activities positively influence the affiliate's sales outside the host market

Finally, we expect that the sales focus of the affiliate is influenced by the overall strategy of the parent firm. MNEs may pursue a multi-domestic strategy or a global strategy (Hout et al. 1982). A multi-domestic strategy is based on the notion that national markets differ with respect to local habits, preferences of consumers, and political and social structures. In order to increase the probability of success, firms have to adjust their products, marketing policy, management style, and even their way of influencing relevant stakeholders to the local circumstances. In order to achieve this, affiliates are usually given large autonomy in operating locally. If the parent firm follows a multi-domestic (or local responsiveness) strategy, affiliates will be inclined to mainly sell their products locally targeting specific needs in the host economy. The affiliates will behave as miniature replicas of the parent.

Global firms, on the other hand, will target many different markets from one location. MNEs focusing on a global strategy expect that equality of preferences and markets exists. The MNE attempts to gain economies of scale by concentrating production in one or a limited number of countries and by exporting its products worldwide (Bartlett and Ghoshal 1987, 1989). Products are not adapted to local sales and can therefore easily be exported from one location to many different markets. Papanastassiou and Pearce (1994) 
emphasise that as competition in many industries becomes increasingly global, many affiliates have developed into regional product mandates, taking full responsibility for the development, production, and international marketing of distinctive products, resulting in an upgrading of the subsidiaries' role. We therefore suggest the following hypothesis:

H6: A parent's multi-domestic strategy negatively influences the affiliate's sales outside the host market

The relationships between each of these determinants and the affiliate's sales focus are summarised in the conceptual model presented in Figure 6.2.

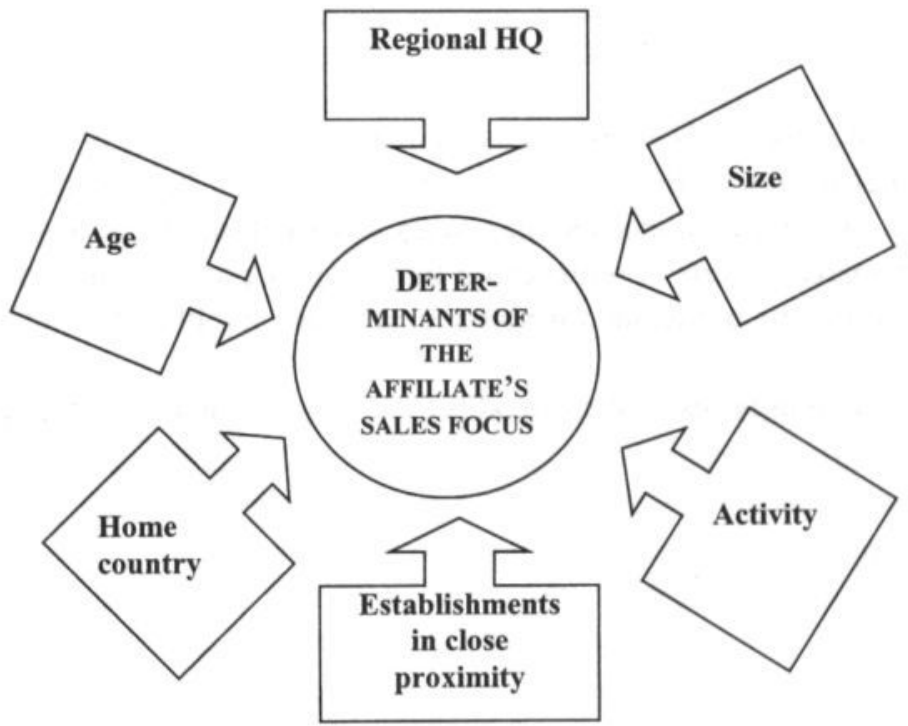

Figure 6.2

Determinants of the affiliate's sales focus

\subsection{Model and methodology}

We expect that the six characteristics of firms as discussed in Section 6.2 will influence the sales focus of the foreign affiliate in the host market. The basic model therefore is:

Sales focus $=$

$\mathrm{f}($ size $[+]$, age $[-]$, regional headquarters $[+]$, home country location $[-]$, activity $[+]$, number of establishments in countries in close proximity to the host $[-])$ 
Because the observations on the dependent variable, sales focus, are discrete, in order to test the model we use binomial and multinomial logit analyses ${ }^{8}$. Binomial logit analysis is oriented to estimating the probability that one event occurs rather than another. In this present study, it would mean a local or a foreign market focus. The binomial logit model can be formalised as follows (Maddala 1983):

$$
P(Y)=\frac{e^{Z}}{1+e^{Z}}
$$

with $\mathrm{Z}$ being a linear combination of the independent variables:

$$
Z=\beta_{0}+\beta_{1} X_{1}+\beta_{2} X_{2}+\ldots .+\beta_{n} X_{n}
$$

where $\mathrm{Y}$ is the choice for the Netherlands as the main focus of the firm sales, the $\beta_{\mathrm{k}}$ 's are the regression coefficients, with $\mathrm{k}=0,1, \ldots, \mathrm{n}$; the $\mathrm{X}_{\mathrm{i}}$ 's are the independent variables with $\mathrm{i}=1,2, \ldots \ldots, \mathrm{n}$ (in this model the maximum $\mathrm{n}$ is 6 ). The choice for a market focus that is mixed or solely exports is represented by (1-Y). A positive sign for a regression coefficient means that the particular variable increases the likelihood of a foreign market focus.

If the model is written in terms of the log odds (= the logit), the direct impact of the $\beta_{\mathrm{k}}$ 's can be shown

$$
\log \frac{P(Y)}{1-P(Y)}=\beta_{0}+\beta_{1} X_{1}+\beta_{2} X_{2}+\ldots \ldots+\beta_{n} X_{n}
$$

Logit models were estimated with Limdep 7.0 using maximum likelihood. This technique estimates those $\beta_{\mathrm{k}}$ 's that make the observed results most likely (Greene 2000) ${ }^{9}$.

\footnotetext{
${ }^{8}$ We use a binomial analysis to distinguish the firms that focus mainly on the Netherlands from the firms that also have sales outside the Netherlands. To further increase our understanding of the exporting firms, we divide this group into two subgroups and use multinomial analyses to determine the characteristics that explain their activities.

9 Several measures exist to evaluate how well an estimated model fits the data. First a classification table can be calculated to compare the predicted focuses with the observed ones. A model is said to classify well if the total percentage of correct predictions is substantially higher than the percentage that would have been obtained by chance. The proportional chance criterion of a random model is $\alpha^{2}+(1-\alpha)^{2}$, where $\alpha$ is the proportion of firms with a Dutch focus in the sample (see Hair Jr. et al. 1998). The classification table also displays the sensitivity rate and the specificity rate of the model. The sensitivity rate indicates the ability of the model to correctly classify the dependent variable with a value of 1 (focus on the Dutch market only), whereas the specificity rate indicated the opposite.

A second way of assessing the goodness of fit is to investigate the likelihood of the sample outcomes, given the estimates of the parameters. A common measure is the -2 times the log likelihood ( $-2 \mathrm{LL})$, which has a small value if the fit is good (Hair Jr. et al. 1998). A perfect fit has a likelihood of 1, and -
} 
The binomial logit model can only be used when the dependent variable is a dichotomous variable. When considering three loci, multinomial rather than binomial logit analysis can be used. Multinomial logit analysis is directed at estimating the effects of independent variables on the probability that a certain state or event occurs. The dependent variable can have more than two values. This is formalised as follows.

Let the variable $Y_{i j}=j$ if the $i$ th observation chooses alternative $\mathrm{j}, \mathrm{j}=0,1,2$. In the current context $i$ represents the individual firm and $j$ represents the sales focus of that firm where $Y_{i j}=0$ represents a choice for only the Netherlands, $Y_{i j}=1$ represents a mixed sales focus, and $Y_{i j}=2$ represents exports from the Netherlands. The multinomial logit model for the probability that $Y_{i j}=j, P\left(Y_{i j}=j\right), j=0,1,2$ can be formulated as

$$
P\left(Y_{i j}=j\right)=\frac{e^{W j}}{1+\sum_{j=1}^{J-1} e^{W j}}
$$

with $\mathrm{W}_{\mathrm{j}}$ being a linear combination of the independent variables

$$
W_{j}=\beta_{j 0}+\beta_{j 1} X_{1}+\beta_{j 2} X_{2}+\ldots .+\beta_{j n} X_{n}
$$

where $\mathrm{j}$ represents the categories of the dependent variable, with $\mathrm{j}=0,1,2$; the $\beta_{\mathrm{k}}$ 's are the regression coefficients, with $\mathrm{k}=0,1, \ldots, \mathrm{n}$; the $\mathrm{X}_{\mathrm{i}}$ 's are the independent variables with $\mathrm{i}=1,2, \ldots \ldots, \mathrm{n}$. Response category $0, \mathrm{P}(\mathrm{Y}=0)$, is the reference category, which is used as the basis for comparison. The probability that a certain response category $\mathrm{j}$ will be selected is the probability compared to reference category $0^{10}$. This model equals the binomial logit model if the number of choices equals 2 .

$2 \mathrm{LL}$ is then 0 . This measure can be used to test whether the predicted model is comparable to the perfect model. An insignificant result indicates that the null hypothesis (that the models resemble each other) cannot be rejected. A third way to determine the goodness of fit is the model- $\chi^{2}$, which tests the null hypothesis that all $\beta_{k}$ 's are zero, except $\beta_{0}$. Whenever the model- $\chi^{2}$ is significant, this null hypothesis can be rejected. In addition to the $\chi^{2}$-tests, several different $\mathrm{R}^{2}$-type measures have been developed to

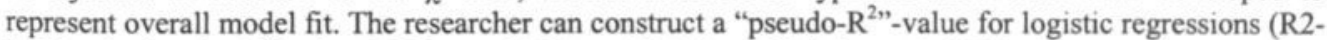
logit) calculated as $R^{2}$ logit $=\left[-2 L L_{\text {null }}-\left(-2 L_{\text {model }}\right)\right] /-2 L L_{\text {null }}$ (Hair Jr. et al. 1998).

Logistic regression can also test the hypothesis that a coefficient is different from zero (zero means that the odds ratio does not change and the probability is not affected), as is done in multiple regression. Instead of using the t-statistic as is done in multiple regression, logistic regression uses the Wald statistic (Hair Jr. et al. 1998).

${ }^{10}$ The goodness of fit of multinomial models can be assessed in several ways (Greene 2000). First, the loglikelihood ratio test will be used. This test is an $\chi^{2}$-based, global test for the significance of the total model, which is calculated as the ration of $-2 \mathrm{LL}$ of the model with only the intercept and the $-2 \mathrm{LL}$ of the full model. The null hypothesis that all the $\beta_{k}$ 's are zero can be rejected if this ratio is significant. We can also do a similar test for all individual $\beta_{k}$ 's. The third test, $\left(\rho^{2}\right)$ is a measure of the overall fit of the model, which is similar to $R^{2}$ in regression analysis. This measure is calculated as $\rho^{2}=1-\mathrm{L}^{\mathrm{F}} / \mathrm{L}^{0}$, where $\mathrm{LF}$ is the 
The usual normalisation $\beta_{0}=0$ (see Allen et al. 1997) permits us to calculate the probability of sales focus on the Netherlands $(\mathrm{Y}=0)$, mixed focus $(\mathrm{Y}=1)$, and export focus $(\mathrm{Y}=2)$ as:

$$
\begin{aligned}
& P\left(Y_{i j}=0\right)=1 / 1+e^{W 1}+e^{W 2} \\
& P\left(Y_{i j}=1\right)=e^{W 1} / 1+e^{W 1}+e^{W 2} \\
& P\left(Y_{i j}=2\right)=e^{W 2} / 1+e^{W 1}+e^{W 2}
\end{aligned}
$$

\subsection{Data and variables}

To test the model, we selected the Netherlands as a case. Being a small country that is part of a larger regional economic entity (the European Union), it is expected that many affiliates located in this particular host country will serve a larger market with their products and services than just the local Dutch market. Due to regional integration, MNEs can rationalise their European activities to exploit economies of scale and scope (Benito et al. 2001). Given the initiating role of the Netherlands in the European Union, we expect these effects to be clearly visible among Dutch foreign affiliates.

The data we use for this study are the same as in Chapter 5. They were gathered using a mail questionnaire survey conducted in fall/winter 1999. For a full description of the questionnaire methodology see Appendix C. The total sample of firms comprised of 469 foreign establishments in the sector, of which we got 127 responses (27.1 percent). Eighty-six firms returned a completed questionnaire $(18.3 \text { percent })^{11}$. Of those 86 firms, 84 could be used for the present analyses.

The market focus of the responding firms is measured as the percentage of sales occurring in the Netherlands. Three foci are distinguished: Group one (local focus) considers only those firms that focus mostly or completely on the Dutch market (targeting the Dutch market with at least 90 percent of the sales from the Dutch affiliate, $n=43$ ). Group two consists of all firms that follow a mixed strategy, focusing on both the Dutch market and other markets supplied from their Dutch base (sales in the Netherlands between 10 and 90 percent of total, $n=23$ ). Group three has an export focus, targeting other markets than the Dutch with at least 90 percent of their sales $(n=18)$.

Figure 6.3 shows how the firms participating in the questionnaire survey can be categorised in the classification developed in Section two of this chapter. Almost half of the participating firms have a foreign market scope. Twenty-eight firms have a broad

loglikelihood of the full model and LO is the loglikelihood of a model with all parameters restricted to zero.

11 Thirty-four firms indicated that they did not want to participate due to lack of time, an overabundance of requests to participate in surveys, principle matter never to answer any questionnaires, ongoing reorganisation, and been in the Netherlands too long to remember the locational decision. 
value-added scope. For the 84 firms for which data on both scales exist, we see that two types of behaviour are generally favoured. First of all, the regional product mandate hubs ( 25 percent of total) where affiliates have a foreign market scope combined with a broad value-added scope. Firms classified in this quadrant overall engage in at least 4 kinds of activities, including regional headquarter functions for many, and sell a large part of their products outside the Netherlands. At the other extreme are single activity satellites that focus on local sales. Forty-three percent of all affiliates in the sample fit into this category. The smallest group included miniature replicas. With only 8 percent of all sample firms, it is unusual for foreign affiliates to have many functions but limit their sales mainly to the Netherlands. The remaining 24 percent is made up of firms that combine a limited value-added scope with a foreign market scope, the export platforms. For our sample of firms, this group turns out to be slightly smaller than the group of affiliates that are regional product mandate hubs.

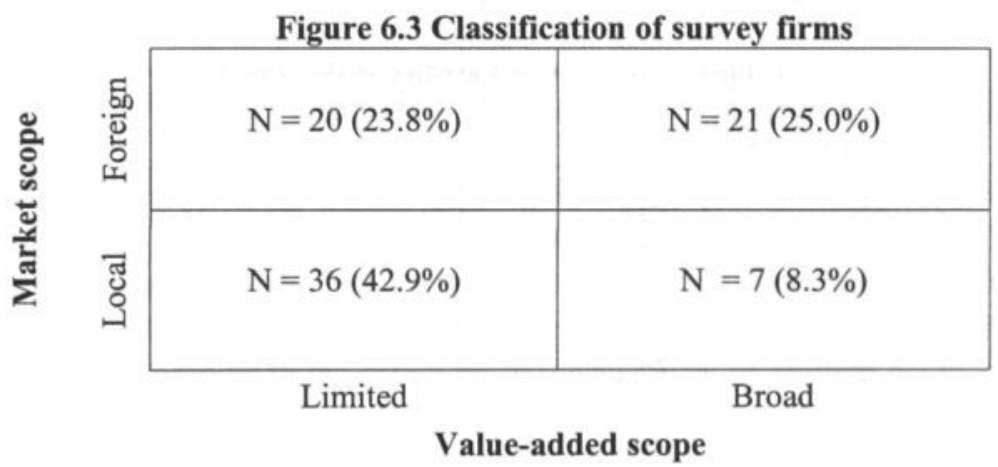

Table 6.1 gives on overview of the six independent variables used in the analyses (age, size, location of parent, regional headquarter activity, number of affiliates in the region, and activity of the affiliate) and the way they were measured. Straightforward single-item measures were used.

Table 6.1 Overview of the variables used in the empirical study

\begin{tabular}{|l|c|c|l|}
\hline Variable & Code & $\begin{array}{l}\text { Expected } \\
\text { Influence on } \\
\text { Export Focus }\end{array}$ & Measurement \\
\hline Firm size & SIZE98 & + & $\begin{array}{l}\text { Number of people employed by the affiliate } \\
\text { (question A2) }\end{array}$ \\
\hline $\begin{array}{l}\text { Age of the local } \\
\text { affiliate }\end{array}$ & AGE & - & $\begin{array}{l}1999-\text { year of establishment of affiliate in the } \\
\text { Netherlands (question A4) }\end{array}$ \\
\hline $\begin{array}{l}\text { European } \\
\text { Headquarters in the } \\
\text { Netherlands }\end{array}$ & REGHQ & + & $\begin{array}{l}\text { Dummy variable: } 1 \text { if the affiliate is a } \\
\text { European Headquarters, zero otherwise } \\
\text { (question A21) }\end{array}$ \\
\hline
\end{tabular}


Table 6.1 Overview of the variables used in the empirical study (continued)

\begin{tabular}{|l|c|c|l|}
\hline Variable & Code & Influence (exp) & Measurement \\
\hline Location of parent & PARENT & - & $\begin{array}{l}\text { Dummy variable: } 1 \text { if the affiliate has a parent } \\
\text { located in the European Union, zero otherwise }\end{array}$ \\
\hline Business activity & ACTIVITY & + & $\begin{array}{l}\text { Dummy variable: } 1 \text { for manufacturing } \\
\text { (importance } 4 / 5 \text { in question A20.2), zero } \\
\text { otherwise }\end{array}$ \\
\hline $\begin{array}{l}\text { Establishments in } \\
\text { close proximity }\end{array}$ & STRATEGY & - & $\begin{array}{l}\text { Proxied by the count of the number of } \\
\text { European countries in which the parent has } \\
\text { establishments (based on question A12) }\end{array}$ \\
\hline
\end{tabular}

Table 6.2 gives the overall descriptive statistics of the variables used in the analyses. Due to missing values for the EU headquarters and the activity, the effective sample is reduced to 84 firms. In Appendix 6.1 an overview is given of the descriptive statistics for the individual groups distinguished in this chapter. The tables give an indication of the differences in the explanatory variables among the distinguished groups.

Table 6.2 Descriptive statistics of the sample

\begin{tabular}{|l|l|l|r|r|r|r|}
\hline & Variable & $\begin{array}{l}\text { Number of } \\
\text { Observations }\end{array}$ & Minimum & Maximum & Mean & Standard deviation \\
\hline 1 & SIZE98 & 84 & 2 & 520 & 66.25 & 113.80 \\
2 & AGE & 84 & 1 & 74 & 16.19 & 14.23 \\
3 & REGHQ & 84 & 0 & 1 & 0.30 & 0.46 \\
4 & PARENT & 84 & 0 & 1 & 0.50 & 0.50 \\
5 & ACTTVITY & 84 & 0 & 1 & 0.18 & 0.39 \\
6 & STRATEGY & 84 & 0 & 14 & 6.24 & 4.91 \\
\hline
\end{tabular}

\subsection{Results}

This section presents the results of the analyses. Tables $6.3 \mathrm{a}$ and $6.3 \mathrm{~b}$ give the correlation matrices for the variables used in the empirical analyses for the 84 firms for which we have data on both scales.

Table 6.3a Correlation matrix binary choice model of sales focus

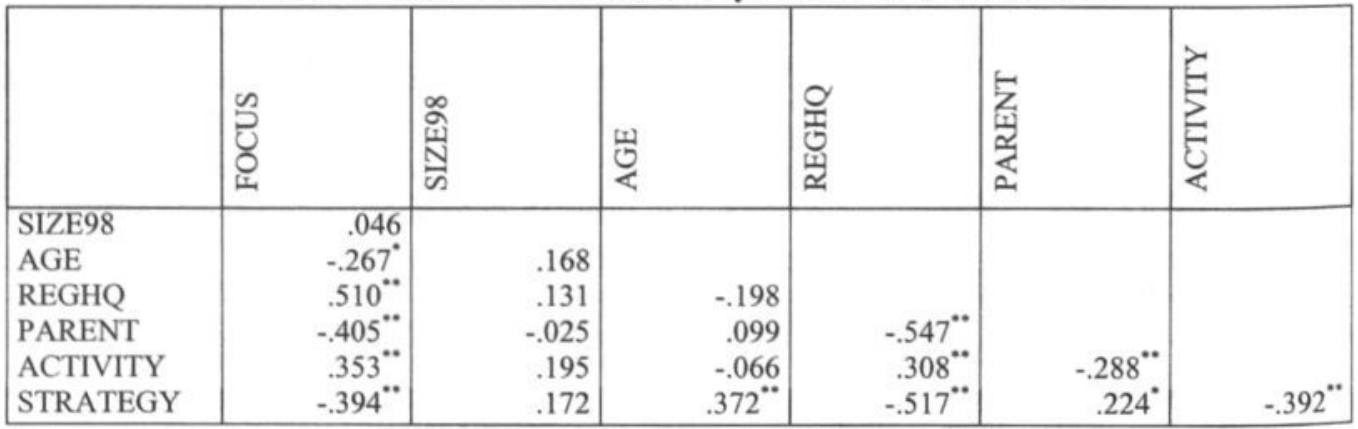

" Correlation is significant at the 0.01 level (2-tailed)

"Correlation is significant at the 0.05 level (2-tailed) 
Most correlations are low, although we find some significant and high correlations, particularly among the variables strategy, regional headquarters, parent location, and activity. The results of the analyses may therefore be biased. To account for this fact, the empirical analyses include both all variables and selections of the variables.

Table 6.3b Correlation matrix multinomial choice model of sales focus

\begin{tabular}{|c|c|c|c|c|c|c|}
\hline & 记 & 啇 & 벵 & $\begin{array}{l}\text { 엄 } \\
\text { 戛 }\end{array}$ & 点 & 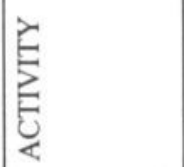 \\
\hline $\begin{array}{l}\text { SIZE98 } \\
\text { AGE } \\
\text { REGHQ } \\
\text { PARENT } \\
\text { ACTIVITY } \\
\text { STRATEGY }\end{array}$ & $\begin{array}{r}.094 \\
-.222^{\circ} \\
.569^{*} \\
-.432^{*} \\
.446^{* *} \\
-.449^{*}\end{array}$ & $\begin{array}{r}.168 \\
.131 \\
-.025 \\
.195 \\
.172\end{array}$ & $\begin{array}{r}-.198 \\
.099 \\
-.066 \\
.372\end{array}$ & $\begin{array}{r}-.547^{*} * \\
.308^{*} * \\
-.517^{*}\end{array}$ & $\begin{array}{r}-.280^{\circ} \\
.229^{\circ}\end{array}$ & $-.392^{*}$ \\
\hline
\end{tabular}

" Correlation is significant at the 0.01 level (2-tailed)

- Correlation is significant at the 0.05 level (2-tailed)

Tables 6.4 and 6.5 show the results of testing the models under varying specifications. Table 6.4 shows the results for the binomial logit estimations (specifications A-E), where only two foci are distinguished. We contrast the firms focussing (almost) completely on the Dutch market with those that (partly or completely) use the Netherlands as an exportplatform. The results indicated the effect on the probability of exports occurring from the base in the Netherlands (where Dutch sales are the base).

Specifications F - J show the results of the multinomial logit estimates (Table 6.5). Three choices exist: focus on the Dutch market, a mixed sales focus, and the export focus. The presented results only consider two foci: $\mathrm{Y}=1$ (mixed) and $\mathrm{Y}=2$ (exports), because the normalisation $\beta_{0}=0$ means that the coefficients for the choice of sales focus only on the Netherlands will all be zero. The results indicate the effect on the probability of a mixed or exports sales focus occurring at the establishment in the Netherlands (where Dutch sales are the base). We separately estimated the regressions by changing the independent variables in order to observe the importance of those variables related to the prediction of the sales focus.

The overall model specification is robust. For all specifications the $\chi^{2}$ statistics are highly significant for testing the null hypothesis that all slopes coefficients are zero for all specifications, indicating at least a 99 percent probability that the coefficients of the explanatory variables are not zero. For specifications F-J the proportional chance criterion $\left(\alpha^{2}+(1-\alpha)^{2}\right)$ is $0.50\left(Y_{\text {Total-n }}=84, Y_{1}-n=43\right)$. The models show a significant improvement over this chance estimation. Specifications A-E all show at least 75 percent of the outcomes to be predicted correctly. The multinomial model specification performs slightly less good than the binomial logit specifications (with about 64 percent of the 
outcomes correctly predicted). We attribute this result to the limited number of observations in the multinomial estimations.

Table 6.4 Determinants of sales focus of FDI into the Dutch electronics industry (binomial)

\begin{tabular}{|c|c|c|c|c|c|}
\hline & A & B & $\mathrm{C}$ & $\mathrm{D}$ & $\bar{E}$ \\
\hline Intercept & $2.123^{\circ}$ & -0.324 & 0.285 & $1.711^{\circ}$ & 0.564 \\
\hline & $(0.587)$ & $(0.450)$ & $(0.638)$ & $(0.630)$ & $(0.847)$ \\
\hline SIZE98 & & & & 0.002 & 0.000 \\
\hline & & & & $(0.003)$ & $(0.003)$ \\
\hline $\mathrm{AGE}$ & $-0.034^{\circ}$ & $-0.039^{\circ}$ & $-0.044^{\circ}$ & $-0.043^{\circ}$ & $-0.041^{\circ}$ \\
\hline & $(0.023)$ & $(0.228)$ & $(0.024)$ & $(0.025)$ & $(0.025)$ \\
\hline REGHQ & & $2.405^{* \cdots}$ & $1.973^{* *}$ & & $1.783^{*}$ \\
\hline & & $(0.703)$ & $(0.763)$ & & $(0.851)$ \\
\hline PARENT & $-1.638^{* * *}$ & & -0.823 & $-1.512^{* * *}$ & -0.883 \\
\hline & $(0.522)$ & & $(0.599)$ & $(0.540)$ & $(0.616)$ \\
\hline ACTIVITY & & $1.967^{* *}$ & $1.882^{* *}$ & 1.403 & $1.674^{\circ}$ \\
\hline & & (0.906) & (0.916) & $(0.926)$ & (1.007) \\
\hline STRATEGY & $-0.137^{\circ *}$ & & & $-0.108^{\circ}$ & -0.037 \\
\hline & $(0.058)$ & & & $(0.063)$ & $(0.074)$ \\
\hline$\chi^{2}$ & $26.24^{\cdots}$ & $33.01^{\cdots \cdots}$ & $34.89^{* *}$ & $30.20^{\cdots}$ & $35.14^{\cdots}$ \\
\hline Degrees of freedom & 3 & 3 & 4 & 5 & 6 \\
\hline$-2 \mathrm{LL}$ & 90.17 & 83.39 & 81.52 & 86.20 & 81.27 \\
\hline $\mathrm{N}$ & 84 & 84 & 84 & 84 & 84 \\
\hline Correctly predicted & & & & & \\
\hline outcomes (\%) & 77.38 & 75.00 & 75.00 & 78.57 & 76.19 \\
\hline
\end{tabular}

Standard errors in parentheses

The results from the specifications are generally consistent with the expectations and make intuitive sense. The direction of the relationship between the characteristic of the affiliate and its sales focus is consistent for the binomial and multinomial specifications. In hypothesis one, we argued that an increase in the size of the affiliate would result in sales outside the host market. However, the results indicate a non-significant and negligible effect of size on sales focus for all specifications. Therefore, no support is found for hypothesis one.

As expected, we find a negative and significant relationship between the age of the affiliate and the sales focus of that affiliate. Foreign affiliates that were established in the Netherlands relatively early are less likely to focus their sales outside the Netherlands. This effect is found for all specifications (A-E) when considering only two sales foci (the Netherlands or exports). We therefore find support for hypothesis two. The results of the multinomial specifications (F-J) show that relative to those firms focussing only on the Netherlands, those exporting part of their sales are younger. Again, this result offers support for hypothesis two. For affiliates that focus all their sales outside the host market, we find no significant relationship between age and sales focus. Overall, the effect appears to be rather small. 
Table 6.5 Determinants of sales focus of FDI into the Dutch electronics industry (multinomial)

\begin{tabular}{|c|c|c|c|c|c|c|c|c|c|c|}
\hline & \multicolumn{2}{|c|}{$\mathrm{F}$} & \multicolumn{2}{|c|}{ G } & \multicolumn{2}{|c|}{$\mathrm{H}$} & \multicolumn{2}{|c|}{ I } & \multicolumn{2}{|c|}{$\mathbf{J}$} \\
\hline & $\mathrm{Y}=1$ & $Y=2$ & $Y=1$ & $Y=2$ & $\mathrm{Y}=1$ & $Y=2$ & $Y=1$ & $\mathrm{Y}=2$ & $\mathrm{Y}=1$ & $Y=2$ \\
\hline \multirow[t]{2}{*}{ Intercept } & $1.28^{* *}$ & $1.63^{* *}$ & -0.43 & $-2.17^{\cdots \cdots}$ & 0.14 & -1.47 & 1.11 & 0.94 & 0.20 & -0.62 \\
\hline & $(0.65)$ & $(0.69)$ & $(0.49)$ & $(0.74)$ & $(0.69)$ & $(0.95)$ & $(0.69)$ & $(0.76)$ & $(0.90)$ & (1.18) \\
\hline \multirow[t]{2}{*}{ SIZE98 } & & & & & & & 0.00 & 0.00 & -0.00 & 0.00 \\
\hline & & & & & & & $(0.00)$ & $(0.00)$ & $(0.00)$ & $(0.00$ \\
\hline \multirow[t]{2}{*}{ AGE } & $-0.05^{*}$ & -0.01 & $-0.05^{\circ}$ & -0.02 & $-0.05^{\circ}$ & -0.03 & $-0.05^{\circ}$ & -0.02 & $-0.05^{\circ}$ & -0.02 \\
\hline & $(0.03)$ & $(0.03)$ & $(0.03)$ & $(0.03)$ & $(0.03)$ & $(0.03)$ & $(0.03)$ & $(0.03)$ & $(0.03)$ & $(0.03)$ \\
\hline \multirow[t]{2}{*}{ REGHQ } & & & $1.93^{\circ *}$ & $3.26^{* \cdots}$ & $1.53^{\circ}$ & $2.76^{\cdots *}$ & & & $1.54^{\circ}$ & $2.15^{\circ *}$ \\
\hline & & & $(0.75)$ & $(0.86)$ & $(0.82)$ & $(0.95)$ & & & $(0.91)$ & (1.08) \\
\hline \multirow[t]{2}{*}{ PARENT } & $-1.30^{* *}$ & $-2.32^{* *}$ & & & -0.77 & -0.97 & $-1.26^{* *}$ & $-2.16^{* * *}$ & -0.79 & -1.15 \\
\hline & $(0.57)$ & $(0.77)$ & & & $(0.65)$ & $(0.91)$ & $(0.59)$ & $(0.82)$ & $(0.65)$ & $(0.98)$ \\
\hline \multirow[t]{2}{*}{ ACTIVITY } & & & 1.38 & $2.80^{\cdots \cdots}$ & 1.31 & $2.70^{\cdots *}$ & 0.94 & $1.75^{\circ}$ & 1.17 & $2.12^{\circ}$ \\
\hline & & & $(0.99)$ & $(1.00)$ & $(1.00)$ & $(1.02)$ & $(1.02)$ & (1.01) & $(1.08)$ & (1.10) \\
\hline \multirow[t]{2}{*}{ STRATEGY } & -0.07 & $-0.28^{* *}$ & & & & & -0.06 & $-0.23^{* *}$ & -0.00 & -0.14 \\
\hline & $(0.06)$ & $(0.09)$ & & & & & $(0.07)$ & $(0.10)$ & $(0.08)$ & $(0.11)$ \\
\hline$\chi^{2}$ & \multicolumn{2}{|c|}{$35.01^{\cdots}$} & \multicolumn{2}{|c|}{$41.90^{\circ \cdots}$} & \multicolumn{2}{|c|}{$43.82^{\cdots *}$} & \multicolumn{2}{|c|}{$40.82^{\cdots}$} & \multicolumn{2}{|c|}{$45.89^{* *}$} \\
\hline DF & \multicolumn{2}{|c|}{6} & \multicolumn{2}{|c|}{6} & \multicolumn{2}{|c|}{8} & \multicolumn{2}{|c|}{10} & \multicolumn{2}{|c|}{12} \\
\hline$-2 L L$ & \multicolumn{2}{|c|}{137.6} & \multicolumn{2}{|c|}{130.7} & \multicolumn{2}{|c|}{128.81} & \multicolumn{2}{|c|}{131.8} & \multicolumn{2}{|c|}{126.7} \\
\hline $\mathrm{N}$ & \multicolumn{2}{|c|}{84} & \multicolumn{2}{|c|}{84} & \multicolumn{2}{|c|}{84} & \multicolumn{2}{|c|}{84} & \multicolumn{2}{|c|}{84} \\
\hline Corr. Pred. (\%) & \multicolumn{2}{|c|}{63.10} & 63. & & & 3.10 & 64.2 & & 64. & 29 \\
\hline
\end{tabular}

$\bullet$ significant at the 0.10 level

$"$ = significant at the 0.05 level

$\cdots$ = significant at the 0.01 level

Standard errors in parentheses 
Firms that act as European headquarters for their parent also have a larger probability to export from their Dutch location. Again this effect is positive and significant in all specifications when tested. The multinomial specifications show that the effect is larger for firms that focus only on export than for firms that have a mixed focus and supply both the Dutch and third markets. The results strongly confirm hypothesis 3. European headquarters are more likely to cover demand in more than just the Dutch market than firms that have not been assigned this special task.

Hypothesis four predicted that affiliates whose parents are located in close proximity to the host country (in the Dutch case parents located in European countries) are less likely to use the host country as an export base than firms coming from other areas in the world. The results offer moderate support for this relationship. Having a European parent negatively influences the probability to export for all specifications. This effect is significant in specifications A, D, F, and I. Again we find that this effect is strongest for the affiliates that have a full export focus. European parents are less inclined to use third markets (in this case the Netherlands) as export bases. They will supply other market either from their headquarters or from local establishments in these markets. The Dutch establishment will then specifically target the Dutch market.

The results indicate that firms that are manufacturing goods in their Dutch affiliate are significantly more likely to export from their location to third markets than firms that do not manufacture goods but only distribute and market goods from their Dutch establishment. This effect is positive and significant for almost all specifications. The effect is particularly strong and significant for firms that export (almost) all their products from their Dutch base (specifications G, H, I, and J for $Y=2$ ). We therefore find strong support for hypothesis 5 .

The significant and negative coefficient of strategy supports our hypothesis that affiliates from parents that have a multi-domestic strategy focus their sales exclusively on their host market. Other markets will be supplied by the sister-establishments located there. This effect is strongest for specifications F and I. Relative to firms that focus on supplying the Dutch market, those that focus on exporting are unlikely to have a parent with a multi-domestic strategic view. This finding is in line with hypothesis six.

Table 6.6 summarises the hypotheses and the test results.

Table 6.6 Hypotheses tests

\begin{tabular}{|l|l|l|l|l|}
\hline & Hypothesis & Bi- \\
& & nomial & \multicolumn{2}{|l|}{ Multi-nomial } \\
\cline { 4 - 5 } & Mixed & Exports \\
\hline 1 & $\begin{array}{l}\text { A larger size of the foreign affiliate positively influences the } \\
\text { affiliate's sales outside the host market }\end{array}$ & No & No & No \\
\hline 2 & $\begin{array}{l}\text { The age of the foreign affiliate negatively influences the } \\
\text { affiliate's sales outside the host market }\end{array}$ & Yes & Yes & No \\
\hline 3 & $\begin{array}{l}\text { A foreign affiliate's status as a regional headquarters for its } \\
\text { parent positively influences the affiliate's sales outside the host } \\
\text { market }\end{array}$ & Yes & Yes & Yes \\
\hline
\end{tabular}


Table 6.6 Hypotheses tests (continued)

\begin{tabular}{|l|l|l|l|l|}
\hline 4 & $\begin{array}{l}\text { Foreign affiliates whose parents are located at close proximity to } \\
\text { the host country will be more focussed on the host market only } \\
\text { than affiliates whose parents are located further away }\end{array}$ & Moderate & Moderate \\
\hline 5 & $\begin{array}{l}\text { Foreign affiliates' host country manufacturing activities } \\
\text { positively influence the affiliate's sales outside the host market }\end{array}$ & Yes & No & Yes \\
\hline 6 & $\begin{array}{l}\text { A parent's multi-domestic strategy negatively influences the } \\
\text { affiliate's sales outside the host market }\end{array}$ & Yes & No & Moderate \\
\hline
\end{tabular}

\subsection{Discussion}

Given the fact that the Netherlands is a relatively small economy, strategically located in the European Union, many affiliates that are located there choose to supply not only the Dutch market with their goods and services, but rather to focus on the European market or even supply the world market from their establishment in the Netherlands. This chapter analyses the most important determinants of the sales focus of foreign affiliates in the Dutch electronics industry.

Figure 6.3 showed how the firms participating in the questionnaire survey can be categorised in the classification developed in Section two of this chapter. Almost half of the participating firms have a foreign market scope. One-third have a broad value-added scope. The results of the logit analyses conducted in this chapter indicate that the firms with a foreign market focus (regional product mandate hubs ( 25 percent of total, quadrant D) and export platforms ( $24 \%$ of total, quadrant C)) overall are younger (established after 1987), manufacture products at their Dutch establishment, have a parent that is located outside Europe that has an overall global strategy. Particularly the younger firms are mostly affected by globalisation and regional integration. Their parents have responded to this development by rationalising sales and production activities, supplying many markets from one establishment, resulting in strategically located regional product mandate affiliates. This result is in line with a recent study by Benito et al. (2001) that emphasises how regional integration has influenced both the scope and the level of competencies in the subsidiary role.

At the other extreme are single activity satellites (quadrant A) that focus on local sales. Fourty-three percent of all affiliates in the sample fit into this category. These affiliates combine a limited value-added scope with a local market scope. Overall, the affiliates categorised in this quadrant are older, have a European parent, and therefore no regional headquarter function.

The smallest group included miniature replicas (quadrant B). Since only 8 percent of all firms fit into this category, it is unusual for foreign affiliates to have many functions but limit their sales mainly to the Netherlands. This result is not surprising, considering the limited market size of the Netherlands. We expect the affiliates in this category to be suppliers to Philips' production units in the Netherlands. They are located in the Netherlands solely to respond quickly to Philips' demand and to be close to their 
customer. Given the huge size of Philips' demand, they do not necessarily need to target other markets anymore.

The present study is only a first attempt to analyse the characteristics of the affiliate that influence its sales focus. The scope of the study is limited to six variables related to the affiliate's activities and characteristics. Future studies could enhance this exploratory analysis by including dimensions of the integration-responsiveness framework proposed by Prahalad and Doz (1987), the configuration-coordination paradigm by Porter (1986), or the strategy-structure interface developed by Birkinshaw and Morrison (1995). Combining all these perspectives could result in a comprehensive multi-dimensional framework explaining the role of the affiliate.

\subsection{Conclusion}

Even though the Netherlands is generally considered a small economy, it has attracted a remarkable amount of inward foreign direct investment (FDI). This study explores the factors that explain the choice for the Netherlands by firms that are conducting activities in the electronics industry. By distinguishing three groups of market foci, we find that firms that target their sales in more markets than just the Dutch in general are younger (established after the acceptance of the Single European act), have manufacturing activities at the host location, and have a European headquarters status. Those affiliates generally have a non-European parent and are usually accompanied by only a few sisteraffiliates from the same parent located in other European countries. They benefit from the continuing process of regional integration within Europe by rationalising their activities to increase the overall efficiency of the foreign operations.

The purpose of this study was to understand the determinants of the sales focus of affiliates in the Dutch electronics. The chapter presents empirical analyses based on questionnaire research. Limiting ourselves to one particular sector reduces the generalisability of the results. However, given that empirical investigations of the roles of foreign affiliates in the Netherlands are lacking completely, our results are a good starting point for further studies. 


\section{Appendix 6.1 Dataoverview}

Table 6A.1 Descriptive statistics NL/other

\begin{tabular}{|l|l|r|r|r|}
\hline Focus & Variable & Mean & Standard deviation & $\mathrm{N}$ \\
\hline NL & Size & 60.17 & 108.85 & 43 \\
& Age & 19.88 & 15.89 & 43 \\
& Regional HQ & 0.00 & 0.26 & 43 \\
& Parent location & 0.70 & 0.46 & 43 \\
& Activity & 0.00 & 0.21 & 43 \\
& Strategy & 8.12 & 3.99 & 43 \\
\hline Exports & Size & 70.57 & 119.90 & 41 \\
& Age & 12.32 & 11.19 & 41 \\
& Regional HQ & 0.54 & 0.50 & 41 \\
& Parent location & 0.29 & 0.46 & 41 \\
& Activity & 0.32 & 0.47 & 41 \\
& Strategy & 4.27 & 5.06 & 41 \\
\hline Total & Size & 65.25 & 113.80 & 84 \\
& Age & 16.19 & 14.23 & 84 \\
& Regional HQ & 0.30 & 0.46 & 84 \\
& Parent location & 0.50 & 0.50 & 84 \\
& Activity & 0.18 & 0.39 & 84 \\
& Strategy & 6.24 & 4.91 & 84 \\
\hline
\end{tabular}

Table 6A.3 Descriptive statistics per group: 3 foci

\begin{tabular}{|l|l|r|r|r|}
\hline Focus & Variable & Mean & Standard deviation & N \\
\hline NL & Size & 60.17 & 108.85 & 43 \\
& Age & 19.88 & 15.89 & 43 \\
& Regional HQ & 0.00 & 0.26 & 43 \\
& Parent location & 0.70 & 0.46 & 43 \\
& Activity & 0.00 & 0.21 & 43 \\
& Strategy & 8.12 & 3.99 & 43 \\
\hline Mixed & Size & 53.28 & 114.97 & 23 \\
& Age & 11.52 & 11.72 & 23 \\
& Regional HQ & 0.39 & 0.50 & 23 \\
& Parent location & 0.39 & 0.50 & 23 \\
& Activity & 0.17 & 0.39 & 23 \\
& Strategy & 5.61 & 5.18 & 23 \\
\hline \multirow{5}{*}{ Exports } & Size & 92.67 & 125.69 & 18 \\
& Age & 13.33 & 10.71 & 18 \\
& Regional HQ & 0.72 & 0.46 & 18 \\
& Parent location & 0.17 & 0.38 & 18 \\
& Activity & 0.50 & 0.51 & 18 \\
& Strategy & 2.56 & 4.48 & 18 \\
\hline
\end{tabular}


Table 6A.3 Descriptive statistics per group

\begin{tabular}{|l|l|r|r|r|}
\hline Group & Variable & Mean & Standard deviation & N \\
\hline A & Size & 67.75 & 117.38 & 36 \\
& Age & 20.97 & 17.05 & 36 \\
& Regional HQ & 0.00 & 0.00 & 36 \\
& Parent location & 0.78 & 0.42 & 36 \\
& Activity & 0.00 & 0.17 & 36 \\
& Strategy & 8.58 & 4.18 & 36 \\
\hline B & Size & 21.21 & 21.28 & 7 \\
& Age & 1429 & 5.31 & 7 \\
& Regional HQ & 0.43 & 0.53 & 7 \\
& Parent location & 0.29 & 0.49 & 7 \\
& Activity & 0.14 & 0.38 & 7 \\
& Strategy & 5.71 & 1.11 & 7 \\
\hline C & Size & 46.86 & 100.73 & 20 \\
& Age & 10.15 & 8.90 & 20 \\
& Regional HQ & 0.20 & 0.41 & 20 \\
& Parent location & 0.50 & 0.51 & 20 \\
& Activity & 0.00 & 0.22 & 20 \\
& Strategy & 6.75 & 5.53 & 20 \\
\hline D & Size & 93.14 & 137.23 & 21 \\
& Age & 14.38 & 12.88 & 21 \\
& Regional HQ & 0.86 & 0.39 & 21 \\
& Parent location & 0.00 & 0.30 & 21 \\
& Activity & 0.57 & 21 \\
& Strategy & 1.90 & 3.18 & 21 \\
\hline Total & Size & 65.25 & 113.80 & 84 \\
& Age & 16.19 & 14.23 & 84 \\
& Regional HQ & 0.30 & 0.46 & 84 \\
& Parent location & 0.50 & 0.50 & 84 \\
& Activity & 0.18 & 0.39 & 84 \\
& Strategy & 6.24 & 4.91 & 84 \\
\hline
\end{tabular}


Chapter 7

\section{CONCLUSIONS}

\subsection{Introduction}

The aim of this thesis was to study foreign business activities in a small country, the Netherlands. With the recent worldwide upsurge in foreign direct investment (FDI) by multinational enterprises (MNEs) the interest in their impact on host economies has increased. FDI is not just a transfer of funds, but consists of a package of capital, new technologies, management skills, and marketing channels. The thesis-introduction has shown that through these transfers foreign affiliates can favourably influence the host economies industrial structure, capital and labour markets, trade relations, and innovative capabilities. If positive spillovers occur, FDI can result in economic prosperity in the host economy. Many governments therefore welcome FDI inflows nowadays or even compete amongst each other to attract new or additional investments.

In general, it is expected that the limited market size and lack of resources in small countries makes them relatively unattractive as locations for foreign affiliates and gives them limited bargaining power with respect to the MNEs. However, some small nations did manage to attract considerable FDI flows. The Netherlands was selected as a case for this study because among the small OECD countries, it attracted the largest amount of inward FDI. An analysis of the determinants of its relative success as a host of foreign affiliates can serve as an example for other small economies.

This thesis therefore provides empirical analyses on the determinants of inward FDI in the Netherlands. Motivated by a curiosity about the Dutch affiliates of large foreign MNEs such as Sony (Japan), Siemens (Germany), IBM (US), Nestlé (Switzerland) and Ericsson (Sweden), this thesis studied the presence, reasons, and behaviour of foreign firms in this host market. First, as a foundation, Chapter one introduced and positioned the thesis and Chapter two discussed important characteristics of the Netherlands as a small economy. Chapter three then analysed the macro-economic determinants of FDI flows to the Netherlands. Chapter four focused on the patterns of agglomeration in Dutch inward FDI. Chapters five and six dealt with the results of a questionnaire survey conducted among foreign establishments in the Dutch electronics industry. Chapter five analysed the locational and firm-specific determinants of the choice for the Netherlands for those electronics establishments. Chapter six focused on the determinants of their sales focus.

The electronics industry was selected due to its dominant position in Dutch inward FDI in manufacturing, as was indicated in the DutchInvest-database that was specifically created 
for the purpose of this study. Within Europe, the electronics industry developed relatively early. The Dutch MNE Philips was among the early initiators. Recently, those "old" European electronics firms have encountered fierce competition - both in their European home markets and worldwide - from new entrants from the US (such as IBM and Hewlett-Packard) and Japan (such as Hitachi, Matsushita, Sony, Canon, and Toshiba). Furthermore, this industry is very dynamic. The shortening life-cycles of products force firms to exploit all market opportunities quickly to recoup the R\&D expenditures necessary for the development of those high tech products. Many firms depend on internationalisation to stay in business. Those electronics MNEs that chose the Netherlands as a location for their foreign affiliate are the topic of Chapters five and six. The content of this concluding chapter is as follows. Section 7.2 summarises the main results of the empirical chapters and provides an overall answer to the research questions of this thesis. Section 7.2.1 concentrates on the presence of foreign firms in the Netherlands. Section 7.2.2 takes a closer look at the most important reasons and determinants of the presence of these firms. Section 7.2.3 discusses the behaviour of those affiliates. After that, Section 7.3 points to the most important strengths and weaknesses of this study. Finally, Section 7.4 ends this thesis by putting forward the most important suggestions for further research.

\subsection{Overall conclusions}

The focus of this thesis is on the factors that explain the entry and activities of foreign firms in a small economy, the Netherlands. We have structured the analysis by looking at three groups of factors. First of all, we examined the actual presence of foreign firms in the Netherlands. Which firms have a subsidiary in the Netherlands? How long have they been in this host nation and where do they come from? Second, we analysed the reasons for these firms to locate in this host market. Do they look for a market for their products or services? Do they exploit certain resources, such as labour and capital? Do the government policies attract foreign firms? Third, we took a closer look at the behaviour of the foreign affiliates in the Netherlands. Did they first explore the Dutch market with exports? Do they sell their products only in the Netherlands or is the de facto market size of the Netherlands actually much larger, including other European nations that can be reached relatively easily from a location in the Netherlands? Which factors distinguish the affiliates that focus only on the Netherlands from those that use the Netherlands as an export-platform for Europe? The following sections provide the overall conclusions of this thesis following this structure.

\subsubsection{Presence of foreign firms in the Netherlands}

FDI inflows in the Netherlands have been considerable with total inward stock amounting to US\$ 215.2 billion in 1999 . Worldwide the country ranks fifth as a recipient of FDI, 
behind the US (US\$ 1087 billion), the UK (US\$ 394 billion), China (US\$ 306 billion), and Germany (US\$ 225 billion). These stock figures are composed of many individual companies that have been in the Netherlands for many decades or came only recently. To analyse Dutch Inward FDI at a micro-level we have created the DutchInvest-database that consists of information on all known foreign affiliates that started activities in the Netherlands in the period up to 1997 and are still in business. By combining a number of data sources, we managed to trace 7484 foreign-owned establishments, employing at least 373438 people. For all firms we have collected information on the year of establishment (and occasionally take-over), the location within the Netherlands, the main SIC-activity at the present site, home country of the parent firm, and number of employees.

Regarding the age of foreign affiliates we find that particularly during the period 19861995 large inflows of foreign firms occurred. This upsurge coincides with the accelerating process of globalisation and the increasing European integration. Fifty-seven firms that are currently listed as having a foreign parent have a starting date before the twentieth century. Most of them actually started off being a Dutch firm but were acquired by a foreign MNE at some stage in their life.

The parent firms are located in 71 different countries. The large majority of investments originates in industrialised countries with the US, the UK and Germany as dominant source nations. Most foreign affiliates in the Netherlands $(37 \%)$ are classified as trade related with financial institutions as a close second (29\%). Only one in eight of the foreign affiliates in the Netherlands currently is a manufacturing establishment. Among the manufacturing firms we see most establishments in industrial and commercial machinery (SIC 35), electronic and other electrical equipment and components (SIC 36), and chemicals and allied products (SIC 28).

We have analysed if and how the establishment pattern of foreign affiliates differs from that of local Dutch firms. We find that indeed foreign firms choose different locations than local ones. Although both Dutch and foreign firms favour a location in the Randstad-area, this is particularly true for foreign establishments, especially for those whose parents are located in Japan or the United States of America. On the other hand, the northern provinces Groningen, Friesland, and Drenthe are significantly less interesting for foreign firms. Less than three percent of all foreign firms locate there.

Of the southern regions, Noord Brabant and Limburg turn out to be interesting locations due to their borders with Belgium and Germany, even though the proportion of all foreign firms that locate there still is comparatively a little lower than that of local firms. This study indicates that those border-regions are particularly attractive for the investors from the neighbouring countries. It is likely that in the near future the increasing importance of the European Union will result in increasing attractiveness of those borderlands compared to other regions, particularly for investments targeting the whole European Union. These affiliates can benefit from the availability of a multi-lingual 
labour pool from the countries bordering the region and the uniform European business rules and regulations.

\subsubsection{Reasons for foreign MNEs to locate in the Netherlands}

The reasons for inward FDI in the Netherlands are studied at three levels of analyses: macro, regional, and micro. At the macro level, we analysed the determinants of the total inward flows of foreign direct investments over the period 1987-1999. This study therefore explored the relationship between investment flows to the Netherlands and five groups of macro-economic variables (market, trade, costs, distance, and environment). The results show that the main positive influences on inward flows are home country's exports to the Netherlands, the labour cost differential between the home and host country, and home country market size. Exports indicate a familiarity with the host market and MNEs use this experience and knowledge of the host country to preserve markets through foreign establishments. Surprisingly the higher labour costs in the Netherlands encouraged FDI flows. Although it is frequently hypothesised that MNEs look for cheap labour - and high labour costs therefore would deter investments - we explain this surprising result by the relatively high Dutch labour quality. Dutch employees are generally highly educated and multi-lingual, making them attractive employees in foreign firms. Most investors are willing to pay higher wages in return for better skills. The most important negative influence is the cultural distance between the Netherlands and the home country. When the foreign affiliate is not used to Dutch business practice, governmental legislation, and customer preferences, it is more difficult and therefore costly, to operate a foreign affiliate in the host market. A large cultural distance between the Netherlands and the MNE's home country therefore discourages the establishment of a local affiliate.

To analyse the determinants of the regional location choice, we explored the relationship between six groups of variables (agglomeration, market, labour, government, infrastructure, and geography) and the location choice of the foreign affiliate in the Netherlands. When considering the choice between the Randstad and the rest of the Netherlands, we find that a choice for the Randstad is explained by the presence of other foreign firms. This result offers strong support for the notion that foreign firms like to cluster around other (previously established) foreign affiliates to benefit from agglomeration economies (resulting for instance from a pool of specialised labour and inputs and technical and knowledge spillovers among firms). This result has important policy implications. As agglomeration economies tend to give rise to virtuous circles of investments, inward FDI is likely to create a cumulative mechanism, in which past inflows engender current and future flows into the host economy. This implies that countries that already attract FDI are those most likely to continue to do so. Therefore, any benefits received from attracting a single investment will be magnified by an increased probability of attracting subsequent similar investments. Governments can 
therefore target foreign firms with incentive programs creating such a virtuous circle. These firms will then act as "magnets" for additional foreign investments into a region.

At the provincial level (considering the choice for one of the 12 provinces in the Netherlands) we again find the importance of the presence of other foreign establishments in the region. Indeed for many smaller firms, being a "follower" can be a well-motivated choice. If a large competitor has chosen a particular location for his Dutch operations, he must have done so after careful consideration of all the possibilities. Given the enormous cost involved in gathering the right information, smaller firms may be inclined to trust the larger firm's decision and follow to the same region. None of the other factors matter. This result must be attributed to the fact that the regional differences in f.e. economic growth or labour availability within the borders of the Netherlands are too small for foreign firms to base their location decision on them. It is more likely that regions in the Netherlands compete with regions in Germany, France, or Belgium than that Groningen and Friesland are noticeably different in the eyes of a foreign investor.

At the level of the individual firm, we have analysed the determinants of foreign direct investment in the Dutch electronics industry. The survey conducted for this purpose analysed the ownership, internalisation, and locational advantages of foreign affiliates operating in the Netherlands. In general, our sample firms are motivated by the need to be close by their customer, the market growth potential in the Netherlands, the multi-lingual population, the size of the Dutch market and the purchasing power of Dutch consumers, and the need to be close to key markets. We therefore find that many investments are market-seeking, although market should be interpreted as comprising not only the Netherlands, but frequently the entire European continent. As a result of the progressing regional integration in Europe, of which the Netherlands was one of the initiators, MNEs are able to rationalise their European affiliates to exploit economies of scale and scope and to more efficiently exploit the comparative advantages of the various member countries within the EU. This is particularly clear for those affiliates that started their Dutch operations after the acceptance of the Single European Act in 1987. They put significantly more emphasis on the favourable location within Europe than affiliates established at an earlier date.

\subsubsection{Behaviour of foreign affiliates in the Netherlands}

Having established who is present in the Netherlands and why, logically led us to investigating the behaviour of those MNEs within the Dutch economy. We find that almost half of the affiliates participating in the survey focus their sales on more markets than just the Netherlands. The results of our study indicate that those affiliates whose sales focus is foreign instead of local (i.e. those affiliates using the Netherlands (partly) as an export base) in general are younger, focus on manufacturing activities (and not just sales), and have a European headquarter status. Those affiliates usually have a nonEuropean parent and only a few sister-affiliates in other European countries. These 
observations confirm our earlier result that the European Union has encouraged firms to rationalise their activities to exploit economies of scale and scope. Those supplying the European market do so with products that are produced in one location (in our study the Netherlands). Their parent has not established affiliates in all European countries, but instead has focused its activities in one or a few countries. Frequently the Dutch establishment's responsibility for the entire European market is formalised by the official European headquarters status assigned by the parent.

Considering only the attractiveness of the Netherlands potentially creates a bias towards what is good, forgetting about what might deter potential investors or could scare away current affiliates. Considering that affiliates, particularly those focusing on exports, are footloose and sensitive to changes in the host country's economic environment, we need to understand the potential problems in the Dutch market as well. We therefore also explored the difficulties of doing business in the Netherlands (reported in Appendix D). The most important problems experienced by foreign managers in the Dutch electronics industry consist of traffic congestion and the availability of high quality labour. Although the Dutch government is currently trying to deal with these issues, this study again stresses the urgent need to solve these problems.

\subsection{Strengths and limitations}

Overall, we can say that the Netherlands has been relatively successful in attracting foreign investors. The results of this study are therefore very interesting for a number of reasons. First, the unique database created for this study (DutchInvest) provides the most comprehensive overview of foreign affiliates currently present in the Netherlands. At the start of this study, such an overview was lacking. By combining several data sources, we managed to provide a very detailed account of who is present, the activities conducted by those affiliates, and the number of people currently employed in those firms. Second, the results of the empirical analyses provide strong support for the generally accepted locational determinants of entry by foreign firms in the Netherlands such as skilled labour, market growth potential, location within Europe, and infrastructure (Schiphol and the Rotterdam harbours). Third, they show that despite the relatively small market size, the Netherlands has been very successful in attracting foreign investors. Due to its favourable location and active role within the European Union, many strategic exportoriented affiliates have chosen the Netherlands as a base for their activities for the entire European continent. Serving the entire European Union allows these affiliates to quickly achieve the necessary sales volume to produce efficiently.

Clearly this study also has a number of limitations. First, it would be useful to conduct more detailed comparative studies for several industries. The choice for the electronics industry was inspired by the importance of electronics in business activities in both the current and future times. However, although studying the electronics sector allowed us to capture almost 30 percent of all foreign manufacturing activities in the Netherlands, other 
sectors can play an important role in the future development of the Dutch economy as well. We would suggest a repetition of this study in the food and beverages sector, the chemical industry, and the metal industry. Second, we base our analyses on the opinions of local managers. Budget and time restrictions did not allow a thorough analysis of headquarters' reasons for operating an affiliate in the Netherlands. Particularly considering the behaviour of affiliates, we would have liked to extend our study to include a comparison between the headquarters' and the affiliates ideas on the activities of those Dutch establishments. Third, this study is limited in its scope, as it considers just one small economy, the Netherlands. Future work should be conducted using data samples from several small countries. This is particularly important considering the unique position the Netherlands has among the group of small industrialised economies. A large part of the Dutch success in attracting foreign investments should be contributed to its favourable geographic location within the European Union. Furthermore, its unique location at the North Sea at the deltas of several large rivers has allowed the development of specific location advantages such as the Rotterdam harbour. Naturally, these advantages cannot be copied to most other small economies.

\subsection{Suggestions for further research}

In spite of these limitations, the study also raises a number of interesting possibilities for future research. First, but most difficult would be an attempt to make this study longitudinal. This would require regular repetition of the questionnaire, for instance every 5 years. Having a longitudinal data set would allow researchers to investigate the dynamics of the changing locational attractiveness of a country. It would also be possible to trace the changes in affiliate behaviour over time. Given the limited time frame for this thesis it was impossible to achieve this with this present study, but it certainly would considerably enhance our knowledge of the dynamics of firm location behaviour.

Furthermore, it would be interesting to expand the study to other industries than electronics, particularly to the ones that the Netherlands Foreign Investment Agency (NFIA) is targeting for additional foreign investments such as chemicals, life sciences/ biotechnology, and information and communication technologies. Finding out the motivations for firms to establish Dutch affiliates in these sectors would enhance the possibilities for policy makers to target their efforts at making the Netherlands an even more attractive location for FDI.

Another topic worth researching is the impact of those foreign establishments on the Dutch economy. This could be done in many ways. Most commonly one looks at the actual employment created by those affiliates as was recently done in an extensive study by Wintjes (2001). His research could be expanded to take additional effects into account. Although more difficult to collect, the realised sales could be taken as an indication of the economic activity of the affiliates. Particularly in capital-intensive industries, sales may be a better proxy for the size of the firm than employment. In 
addition, it would be interesting to explore the financial structure of the foreign affiliates to investigate their influence on the capital market.

Considering that the influence of foreign affiliates is also determined by the transfer or spill-over of unique knowledge, technology, and management skills, a separate study should try to quantify the importance of these knowledge flows. Does active R\&D collaboration exist between local firms and foreign affiliates? One could investigate the strategic alliances among foreign firms or between those foreign affiliates and Dutch firms as an indicator of the economic relationships between them. Furthermore, we could investigate the actual output resulting of the research collaborations by investigating patent applications resulting from these strategic alliances. For dynamic high tech industries such as electronics this would significantly enhance our knowledge of the impact of the firm on the Dutch economy.

The DutchInvest database created for the analyses in this thesis could be updated regularly to monitor the trends in inward FDI in the Netherlands. It would allow researchers and policy makers to monitor the changing establishment behaviour of foreign MNEs. One interesting expansion of the DutchInvest database would be to include the share of foreign ownership. The sources used to create the database did not reveal the actual foreign share in the establishment. One would have to approach the individual affiliates for this information. Furthermore, one could also include the mode of establishment, either greenfield or acquisition. Mergers and acquisitions (M\&As) differ significantly from greenfield establishments. Rather than expanding the production capacity in a country, existing capacity just changes ownership when an established local firm is bought by a foreign MNE. In addition, it is generally believed that M\&As result in less transfer of skills and technology and therefore contribute less to the host economy. Although for some foreign affiliates this information is already present in the DutchInvest database, the increasing importance of mergers and acquisitions encourages additional research in this field for the Netherlands and necessitates an expansion of the database.

Finally, repeating this study in Belgium or making a comparative study of the Netherlands and Belgium as hosts of FDI would be most interesting. Belgium is another small economy with characteristics quite similar to the Netherlands in terms of favourable location within Europe, membership to the EU, location at the North Sea, and multi-lingual population. Exploring the determinants for a choice for either the Netherlands or Belgium could reveal policy variables that might be controlled to encourage additional investments.

To conclude, a large array of avenues for future research is available. It is hoped that the efforts and findings of this present study will encourage and facilitate these additional research projects. 
$\sqrt{2}$

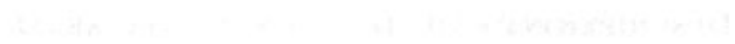

(1)

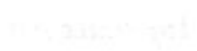

(1)

(1)

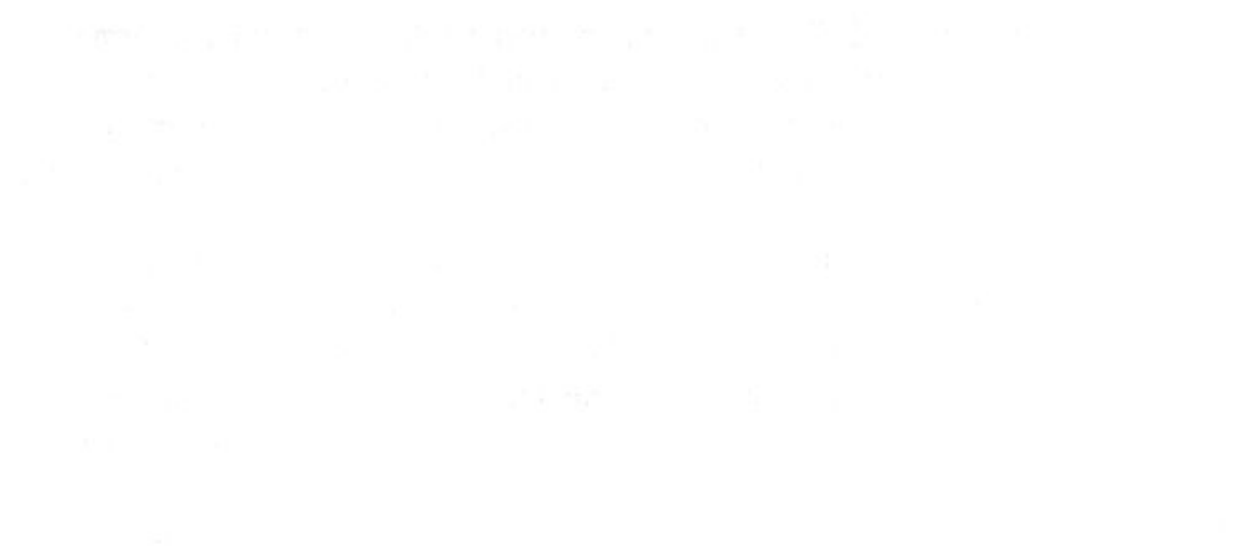

(1)

(1)

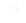

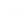


Appendix A

\section{DESCRIPTION OF THE DUTCHINVEST DATABASE}

\section{A.1 Introduction}

To analyse Dutch Inward FDI at the micro-level we have collected information on all known affiliates that started activities in the Netherlands in the period up to $1997^{1}$ and are still in business. We acknowledge the fact that lists of firms are never exhaustive, up-todate, and fully accurate. We, therefore, have combined several sources to make the database as extensive as possible.

First of all, we have used the 1996 and 1997 Dun \& Bradstreet CDs to locate a large number of foreign firms conducting activities in the Netherlands. These addresses have been updated using the printed version of Dun's "foreign firms in the Netherlands 1999". Furthermore, the database has been complemented by firms listed in the ABC-Directory of Firms (1999). Japanese firms listed by JETRO were also included. To check the information achieved in this way, we traced all firms in our list on the 1999 REACH-A database (review and analysis of companies in Holland). That way, missing data were added and locations and activities were verified.

This search resulted in a database of 7484 foreign establishments, employing at least 372428 people $^{2}$. For all firms we have traced the year of establishment (and occasionally of take-over) (Section A2) their location in the Netherlands (Section A3), their main SICactivity (Section A4), home country of parent (Section A5) and number of employees.

\section{A.2 Age}

Table A.1 presents on overview of the start-up year of firms that are currently controlled by foreign firms. This table includes both new greenfield investments and take-overs. We see that particularly during the period 1986-1995 large inflows of foreign establishments occurred. Most investments that occurred before 1900 are firms that were started by

\footnotetext{
${ }^{1}$ Occasionally we could also add information on establishments or take-overs of a more recent date. However, for the years following 1997 data are incomplete. For 1999, the City of Amsterdam alone reported 94 new establishments (Amsterdam the Newsletter, no. 5.5; 25 May, 2000), a new record. These firms, however, do not appear in the official directories yet, and are therefore more difficult to trace and not always included in our sample.

${ }^{2}$ For more than 90 percent of all foreign establishments in the Netherlands employment data are available. It is reasonable to assume that all the other firms employ at least one person. On average the establishments employ 55 people, which would increase total employment in foreign firms to over 400000 .
} 
Dutch entrepreneurs, but were taken over by foreign investors at some point in their lives. An important example is the Dommelsch Brewery, established in 1744, but taken-over by a Belgian investor in 1968. We have decided to report the original establishment, because taking over a firm also results in taking over its clientele, distribution channels etc. This may influence a firm's success and chances of survival. The change in ownership should therefore not be seen as a new investment. Excluding take-overs from the sample would bias the representation of foreign ownership. In the database we however try to give an overview of all foreign control, therefore including take-overs as well.

Tabel A1: Vintage of foreign investments present in the Netherlands in 1997

\begin{tabular}{|r|r|r|r|r|r|r|r|r|}
\hline Year & $\begin{array}{r}\text { Num- } \\
\text { ber }\end{array}$ & $\begin{array}{r}\text { Employ- } \\
\text { ment }\end{array}$ & $\begin{array}{r}\text { Year } \\
1744-1849\end{array}$ & $\begin{array}{r}\text { Num- } \\
\text { ber }\end{array}$ & $\begin{array}{r}\text { Employ- } \\
\text { ment }\end{array}$ & Year & $\begin{array}{r}\text { Num- } \\
\text { ber }\end{array}$ & $\begin{array}{r}\text { Employ- } \\
\text { ment }\end{array}$ \\
$1850-1899$ & 46 & 4101 & 1959 & 45 & 5811 & 1979 & 143 & 18223 \\
$1900-1909$ & 36 & 11907 & 1960 & 57 & 4126 & 1980 & 145 & 4629 \\
$1910-1919$ & 55 & 13449 & 1962 & 66 & 6638 & 1982 & 182 & 5169 \\
$1920-1929$ & 126 & 12804 & 1963 & 60 & 6301 & 1983 & 191 & 4181 \\
$1930-1939$ & 137 & 15751 & 1964 & 68 & 6815 & 1984 & 221 & 4842 \\
$1940-1945$ & 32 & 5440 & 1965 & 60 & 5462 & 1985 & 191 & 3372 \\
1946 & 17 & 2887 & 1966 & 66 & 3866 & 1986 & 241 & 3254 \\
1947 & 10 & 1322 & 1967 & 58 & 2681 & 1987 & 311 & 5808 \\
1948 & 21 & 4433 & 1968 & 85 & 14066 & 1988 & 330 & 9133 \\
1949 & 13 & 2833 & 1969 & 72 & 10541 & 1989 & 483 & 12177 \\
1950 & 22 & 3415 & 1970 & 77 & 6093 & 1990 & 441 & 15133 \\
1951 & 15 & 542 & 1971 & 92 & 7408 & 1991 & 425 & 7583 \\
1952 & 26 & 2794 & 1972 & 120 & 11183 & 1992 & 386 & 10933 \\
1953 & 23 & 2600 & 1973 & 145 & 11325 & 1993 & 361 & 7763 \\
1954 & 24 & 3795 & 1974 & 127 & 3128 & 1994 & 331 & 8400 \\
1955 & 26 & 2512 & 1975 & 122 & 4488 & 1995 & 258 & 5225 \\
1956 & 36 & 3833 & 1976 & 124 & 2601 & 1996 & 99 & 2788 \\
1957 & 31 & 1559 & 1977 & 114 & 4522 & Unknown & 31 & 34 \\
1958 & 32 & 7147 & 1978 & 136 & 4363 & Total & $\mathbf{7 4 4 7}$ & 371148 \\
\hline
\end{tabular}

Source: DutchInvest Database (1999)

\section{A.3 Regional spread of foreign establishments}

Table A2 gives a description of the location in the Netherlands that foreign investors chose for their establishment. We can see that the majority of firms (67 percent) chooses to locate in the Randstad-region: Noord Holland, Zuid Holland, and Utrecht. A large number of firms (almost 15 percent of total) is also located in Noord Brabant, a region that borders with Belgium. The locations in the north of the Netherlands (Groningen, 
Friesland, and Drenthe) are least attractive to foreign investors. Less then 3 percent of all investors start up activities there.

Table A2: Regional Spread of foreign establishments in the Netherlands in 1999

\begin{tabular}{|l|r|r|r|r|}
\hline Region & $\begin{array}{r}\text { Number of } \\
\text { Companies }\end{array}$ & Share in total & Employment & Share in total \\
\hline Groningen & 65 & 0.87 & 4110 & 1.10 \\
Friesland & 40 & 0.53 & 1072 & 0.29 \\
Drenthe & 50 & 0.67 & 2562 & 0.69 \\
Overijssel & 184 & 2.46 & 18439 & 4.95 \\
Gelderland & 569 & 7.60 & 35480 & 9.53 \\
Flevoland & 84 & 1.12 & 2982 & 0.80 \\
Noord Holland & 2399 & 32.06 & 116048 & 31.16 \\
Utrecht & 707 & 9.45 & 35246 & 9.46 \\
Zuid Holland & 1882 & 25.15 & 74623 & 20.04 \\
Noord Brabant & 1109 & 14.82 & 54107 & 14.53 \\
Zeeland & 72 & 0.96 & 9908 & 2.66 \\
Limburg & 323 & 4.32 & 17851 & 4.79 \\
Total & 7484 & & 372428 & \\
\hline
\end{tabular}

Source: DutchInvest Database (1999)

\section{A.4 Sectoral distribution of foreign establishments in the Netherlands}

Table A3 gives a detailed overview of all establishments ordered by SIC1987. Foreign establishments are particularly important in repair and trade, division G (37 percent of total). Financial institutions (division J) follow, with 29 percent of total establishments. One out of eight firms is in manufacturing. Among the manufacturing firms we see most establishments in Industrial and Commercial Machinery and Computer Equipment (SIC 35), Electronic and Other Electrical Equipment and Components (SIC 36), and Chemicals and Allied Products (28).

Table A3: Sectoral distribution of foreign establishments in the Netherlands in 1999

\begin{tabular}{|l|r|r|r|}
\hline Description of the Sector & SIC codes & Number of firms & Employment \\
\hline Division A: Agriculture, forestry and fishing & & & \\
Agricultural production - crops & 01 & 8 & 666 \\
Agricultural production - livestock & 02 & 7 & 85 \\
Agricultural services & 07 & 1 & 28 \\
Fishing, hunting and trapping & 09 & 1 & NA \\
& & & NA \\
Division B: Mining & 10 & 2 & 4 \\
Metal mining & 11 & 2 & \\
\end{tabular}




\begin{tabular}{|c|c|c|c|}
\hline Description of the Sector & SIC codes & Number of Firms & Employment \\
\hline Coal Mining & 12 & 1 & 3 \\
\hline Oil \& Gas Extraction & 13 & 36 & 1398 \\
\hline Mining \& Quarrying of Non-Metallic Minerals & 14 & 3 & 22 \\
\hline \multicolumn{4}{|l|}{ Division C: Construction } \\
\hline Building Construction - General Contractors & 15 & 18 & 763 \\
\hline Heavy Construction & 16 & 23 & 648 \\
\hline Construction - Special Trade Contractors & 17 & 59 & 2719 \\
\hline \multicolumn{4}{|l|}{ Division D: Manufacturing } \\
\hline Food and Kindred Products & 20 & 64 & 18752 \\
\hline Tobacco Products & 21 & 5 & 2845 \\
\hline Textile Mill Products & 22 & 12 & 2502 \\
\hline Apparel & 23 & 18 & 1274 \\
\hline Lumber and Wood Products & 24 & 11 & 650 \\
\hline Furniture and Fixtures & 25 & 10 & 532 \\
\hline Paper and Allied Products & 26 & 35 & 8989 \\
\hline Printing, Publishing, and Allied Products & 27 & 45 & 1597 \\
\hline Chemicals and Allied Products & 28 & 130 & 17835 \\
\hline Petroleum Refining and Related Industries & 29 & 9 & 1062 \\
\hline Rubber and Miscellaneous Plastics Products & 30 & 62 & 7874 \\
\hline Leather \& Leather Products & 31 & 2 & 55 \\
\hline Stone, Clay, Glass, and Concrete Products & 32 & 29 & 4275 \\
\hline Primary Metal Industries & 33 & 31 & 3571 \\
\hline Fabricated Metal Products & 34 & 88 & 7455 \\
\hline Industrial and Commercial Machinery and & 35 & 177 & 14569 \\
\hline \multicolumn{4}{|l|}{ Computer Equipment } \\
\hline Electronic and Other Electrical Equipment and & 36 & 97 & 13189 \\
\hline \multicolumn{4}{|l|}{ Components } \\
\hline Transportation Equipment & 37 & 41 & 3531 \\
\hline Measuring, Analyzing and Controlling Equipment & 38 & 64 & 7005 \\
\hline Miscellaneous Manufacturing Industries & 39 & 20 & 1634 \\
\hline \multicolumn{4}{|l|}{$\begin{array}{l}\text { Division E: Transportation, Communications, } \\
\text { Electric, Gas, and Sanitary Services }\end{array}$} \\
\hline Local and Suburban Transit and Interurban & 41 & 2 & 4 \\
\hline \multicolumn{4}{|l|}{ Highway Passenger Transportation } \\
\hline Motor Freight Transportation and Warehousing & 42 & 85 & 3434 \\
\hline Water Transportation & 44 & 38 & 726 \\
\hline Transportation by Air & 45 & 42 & 895 \\
\hline Transportation Services & 47 & 222 & 9805 \\
\hline Communications & 48 & 14 & 629 \\
\hline
\end{tabular}




\begin{tabular}{|c|c|c|c|}
\hline Description of the Sector & SIC codes & Number of Firms & Employment \\
\hline Electric, Gas, and Sanitary Services & 49 & 4 & 31 \\
\hline \multicolumn{4}{|l|}{ Division F: Wholesale Trade } \\
\hline \multicolumn{4}{|l|}{ Durable Goods } \\
\hline Motor Vehicles and parts & 501 & 69 & 8717 \\
\hline Furniture and Homefurnishings & 502 & 92 & 762 \\
\hline Lumber and Other Construction Materials & 503 & 120 & 2273 \\
\hline Professional and Commercial Equipment and & 504 & 135 & 9612 \\
\hline \multicolumn{4}{|l|}{ Supplies } \\
\hline Metals and Minerals & 505 & 105 & 3059 \\
\hline Electrical Goods & 506 & 360 & 11204 \\
\hline Hardware, and Plumbing and Heating Equipment & 507 & 89 & 1591 \\
\hline Machinery, Equipment, and Supplies & 508 & 785 & 26739 \\
\hline Miscellaneous Durable Goods & 509 & 138 & 1707 \\
\hline \multicolumn{4}{|l|}{ Non-durable Goods } \\
\hline Paper and Paper Products & 511 & 81 & 1234 \\
\hline Drugs, Drug Proprietaries, and Druggists' Sundries & 512 & 136 & 4268 \\
\hline Apparel, Piece Goods, and Notions & 513 & 100 & 1097 \\
\hline Groceries and Related Products & 514 & 142 & 1967 \\
\hline Farm-Product Raw Materials & 515 & 26 & 419 \\
\hline Chemicals and Allied Products & 516 & 167 & 6027 \\
\hline Petroleum and Petroleum Products & 517 & 26 & 2363 \\
\hline Beer, Wine, and Distilled Alcoholic Beverages & 518 & 6 & 25 \\
\hline Miscellaneous Non-durable Goods & 519 & 121 & 2305 \\
\hline \multicolumn{4}{|l|}{ Division G: Retail Trade } \\
\hline Building Materials, Hardware, Garden Supplies & 52 & 4 & 268 \\
\hline General Merchandise Stores & 53 & 4 & 26 \\
\hline Food Stores & 54 & 5 & 1504 \\
\hline Automotive Dealers and Gasoline Service Stations & 55 & 3 & 56 \\
\hline Apparel and Accessory Stores & 56 & 20 & 370 \\
\hline Home Furniture, Furnishings, and Equipment Stores & 57 & 8 & 74 \\
\hline Eating and Drinking Places & 58 & 8 & 122 \\
\hline Miscellaneous Retail & 59 & 27 & 1145 \\
\hline \multicolumn{4}{|l|}{ Division H: Finance, Insurance, and Real Estate } \\
\hline Depository Institutions & 60 & 37 & 4635 \\
\hline Non-depository Credit Institutions & 61 & 236 & 15305 \\
\hline \multirow{2}{*}{\multicolumn{4}{|c|}{ Exchanges }} \\
\hline Insurance Carriers & & & \\
\hline Insurance Agents, Brokers, and Service & 64 & 15 & 271 \\
\hline Real Estate & 65 & 119 & 2503 \\
\hline
\end{tabular}




\begin{tabular}{|c|c|c|c|}
\hline Description of the Sector & SIC codes & Number of Firms & Employment \\
\hline Holding Offices & 671 & 1530 & 81309 \\
\hline Investment Offices + Miscellaneous Investing & $672-679$ & 141 & 1059 \\
\hline \multicolumn{4}{|l|}{ Division I: Services } \\
\hline Hotels, Rooming Houses, Camps, Other Lodging & 70 & 22 & 2694 \\
\hline Personal Services & 72 & 7 & 124 \\
\hline Business Services & 73 & 557 & 20238 \\
\hline Automotive Repair, Services and Parking & 75 & 20 & 280 \\
\hline Miscellaneous Repair Services & 76 & 10 & 227 \\
\hline Motion Pictures & 78 & 17 & 66 \\
\hline Amusement and Recreational Services & 79 & 10 & 207 \\
\hline Health Services & 80 & 6 & 33 \\
\hline Legal Services & 81 & 1 & 8 \\
\hline Educational Services & 82 & 11 & 867 \\
\hline Social Services & 83 & 1 & 9 \\
\hline Museums, Art Galleries, and Botanical and & 84 & 2 & 59 \\
\hline \multicolumn{4}{|l|}{ Zoological Gardens } \\
\hline Membership Organizations & 86 & 2 & 2 \\
\hline Engineering, Accounting, Research and Related & 87 & 3 & 1145 \\
\hline Services, not Elsewhere Classified & 89 & 115 & 4036 \\
\hline Miscellaneous Industries, not elsewhere classified & 9999 & 123 & 993 \\
\hline Total & & 7484 & 372428 \\
\hline
\end{tabular}

Source: DutchInvest Database (1999)

\section{A.5 Home country of foreign establishments}

In total, 71 countries had establishments in the Netherlands in 1999. However, the importance of countries differs significantly. Some countries, like Zambia, Botswana, Chile, and Ivory Coast have only one establishment, while the largest investor in terms of establishments, the United Kingdom, has as many as 1386 . We can see from Table A4 that those countries that appeared to be the largest foreign investors in the Netherlands in Chapter two also have the most establishments. The United Kingdom, the Federal Republic of Germany, and the US all have more than 1300 establishments. Belgium, France, and Japan follow, making up 8.6, 6.3 and 5.6 percent respectively of all establishments in 1999. Sixty-five percent of all establishments resulted from intraEuropean investment flows. These investments became more important during the late 1980 s and early 1990s. Furthermore the importance of Japanese investments, in particular 
during the early $1990 \mathrm{~s}$, is quite considerable with total Japanese establishments amounting to 417 .

Tabel A4: Country of origin of investments in the Netherlands, 1997

\begin{tabular}{|c|c|c|c|}
\hline Home country & $\begin{array}{l}\text { Number of } \\
\text { Establishments }\end{array}$ & $\begin{array}{l}\text { Total } \\
\text { Employment }\end{array}$ & Examples \\
\hline Algeria & 1 & 4 & Sonatrading Amsterdam BV \\
\hline Aruba & 3 & 8 & Emco International NV \\
\hline Australia & 69 & 3402 & $\begin{array}{l}\text { Burns Philp European Holdings BV, Ampolex } \\
\text { International BV }\end{array}$ \\
\hline Austria & 48 & 1331 & $\begin{array}{l}\text { Mayr Melnhof Holdings BV, Zumtobel Benelux } \\
\text { BV }\end{array}$ \\
\hline Belgium & 643 & 17741 & Fina Nederland BV, Solvay Drake NV \\
\hline Bermuda & 1 & 18 & Panametrics BV \\
\hline Botswana & 1 & 3 & Allied Meat Importers Netherlands BV \\
\hline Brazil & 8 & 72 & Banco Do Estado de Sao Paulo SA \\
\hline Bulgaria & 2 & 9 & Rastem BV \\
\hline Canada & 82 & 6461 & $\begin{array}{l}\text { McCain Foods Holland BV, Clyde Petroleum } \\
\text { Exploitatie BV }\end{array}$ \\
\hline Cayman Islands & 1 & 4 & Bridge Marine Fuels BV \\
\hline Chile & 1 & 7 & Pacific Ores and Trading BV \\
\hline China & 1 & 4 & Chinapack Europe bv \\
\hline Croatia & 4 & 36 & Monting \\
\hline Cyprus & 4 & 80 & Dietsmann Technologies BV \\
\hline Czech Republic & 4 & 41 & Praneda BV \\
\hline Denmark & 135 & 13517 & Danisco-Groko Foods BV, Itho BV \\
\hline $\begin{array}{l}\text { Fed. Republic of } \\
\text { Germany }\end{array}$ & 1368 & 58990 & $\begin{array}{l}\text { Mercedez-Benz Nederland BV, Raab Kärcher, } \\
\text { BasF Nederland BV }\end{array}$ \\
\hline Finland & 65 & 4240 & $\begin{array}{l}\text { Kemira Chemicals BV, Finnair BV, Kone Starlift } \\
\text { BV }\end{array}$ \\
\hline France & 471 & 23098 & $\begin{array}{l}\text { Alcatel Telecom Nederland BV, Total Nederland } \\
\text { NV }\end{array}$ \\
\hline Gabon & 1 & 9 & Air Gabon Cargo Company \\
\hline Georgia & 1 & 3 & Konitsi \\
\hline Gibraltar & 1 & 1 & First Futures Brokers Ltd. \\
\hline Greece & 3 & 40 & Olympic Airways SA \\
\hline Greenland & 1 & 53 & Wolfking Holding BV \\
\hline Guyana & 1 & 2 & Breitenstein Producten BV \\
\hline Hong Kong & 30 & 238 & Laser Computer Europe BV \\
\hline Hungary & 2 & 9 & Malev Hungarian Airlines \\
\hline Iceland & 2 & 13 & Icelandair \\
\hline India & 2 & 8 & Zenith International BV \\
\hline Indonesia & 7 & 122 & NV de Indonesisch Overzeese Bank \\
\hline Iran & 2 & 9 & National Iranian Oil Company Nederland \\
\hline Ireland & 83 & 3121 & Avonmore Foods BV, Bell Lijn BV \\
\hline Israel & 47 & 643 & $\begin{array}{l}\text { El Al Israel Airlines BV, Amsterdam Fertilizers } \\
\text { BV }\end{array}$ \\
\hline
\end{tabular}




\begin{tabular}{|c|c|c|c|}
\hline Home country & $\begin{array}{l}\text { Number of } \\
\text { Establishments }\end{array}$ & $\begin{array}{l}\text { Total } \\
\text { Employment }\end{array}$ & Examples \\
\hline Italy & 216 & 3678 & $\begin{array}{l}\text { Fiat Auto Nederland BV, Merloni } \\
\text { Huishoudapparaten BV }\end{array}$ \\
\hline Ivory Coast & 1 & 22 & Eimskip (Transport) BV \\
\hline Japan & 417 & 21272 & Toshiba, Konica, Koyo Europe \\
\hline Jordan & 2 & 27 & Royal Jordanian Airlines \\
\hline Korea, Rep. Of & 23 & 305 & $\begin{array}{l}\text { Samsung Electronics Nederland BV, Daewoo } \\
\text { Corp. }\end{array}$ \\
\hline Kuwait & 3 & 32 & Kuwait Airways Corporation \\
\hline Lebanon & 1 & 15 & TMA (Transmeditaranean Airways) \\
\hline Liechtenstein & 16 & 125 & Biwex NV, Waiko Nederland BV \\
\hline Luxembourg & 105 & 3898 & Arbed SA, Isochem BV \\
\hline Malaysia & 9 & 365 & AAF-International BV \\
\hline Mexico & 5 & 152 & Sunward Acquisitions bv \\
\hline Morocco & 2 & 21 & Royal Air Maroc \\
\hline New Zealand & 8 & 129 & Alex Harvey Holdings (Europe) BV \\
\hline Nigeria & 2 & 16 & Nigerian Airways Ltd. \\
\hline Norway & 35 & 1328 & Hydro Agri Rotterdam BV \\
\hline Panama & 5 & 418 & Pharr Holding BV \\
\hline Philippines & 3 & 5 & Philippine National Bank \\
\hline Poland & 2 & 3 & Hollpeks BV \\
\hline Portugal & 9 & 37 & Oliveira Holland BV \\
\hline Russian & 1 & 10 & Stolichny Bank International NV \\
\hline Federation & & & \\
\hline Saudi Arabia & 4 & 21 & Saudia, Saudi Arabian Airlines \\
\hline Singapore & 10 & 86 & Microtek Europe BV \\
\hline Slovakia & 1 & 6 & Petrimex Benelux BV \\
\hline South Africa & 4 & 65 & Berlon International BV \\
\hline Spain & 52 & 410 & Iberia Lineas Aereas de Espana \\
\hline Suriname & 6 & 28 & Surinam Airways \\
\hline Sweden & 248 & 16483 & $\begin{array}{l}\text { Atlas Copco Constr. \& Mining Distribution BV; } \\
\text { Sandvik Benelux B.V. }\end{array}$ \\
\hline Switzerland & 414 & 22409 & Liebherr Nederland BV, Roche Nederland BV \\
\hline Taiwan & 37 & 386 & Janus Technologies BV \\
\hline Thailand & 1 & 2 & Varanya BV \\
\hline Turkey & 4 & 50 & Demir-Halk Bank (Nederland) NV \\
\hline United Arab Em. & 2 & 224 & Wavin Repox BV \\
\hline United Kingdom & 1386 & 61439 & Rentokil Hokatex BV \\
\hline United States & 1350 & 105584 & Du Pont de Nemours (Nederland) BV, Mars BV \\
\hline Venezuela & 3 & 19 & PDVSA Services bv \\
\hline Yugoslavia & 1 & 10 & Yugoslovenski Aero Transport \\
\hline Zambia & 1 & 7 & Air Cargo Intercontinental \\
\hline Total & 7484 & 372428 & \\
\hline
\end{tabular}

Source: DutchInvest Database (1999) 
Appendix $B$

\section{QUESTIONNAIRE}

\section{FOREIGN DIRECT INVESTMENT IN THE \\ ELECTRONICS SECTOR IN THE NETHERLANDS}

Research group:

Drs Annelies Hogenbirk (UM, the Netherlands)

Prof. Dr. John Hagedoorn (MERIT, the Netherlands)

Dr. Rajneesh Narula (Oslo University, Norway)

Maastricht University Faculty of Economics and Business Administration Department of Management Sciences Strategy \& Logistics P.O.Box 616 6200 MD Maastricht Tel: 043-3883769 Fax: 043-3884893 

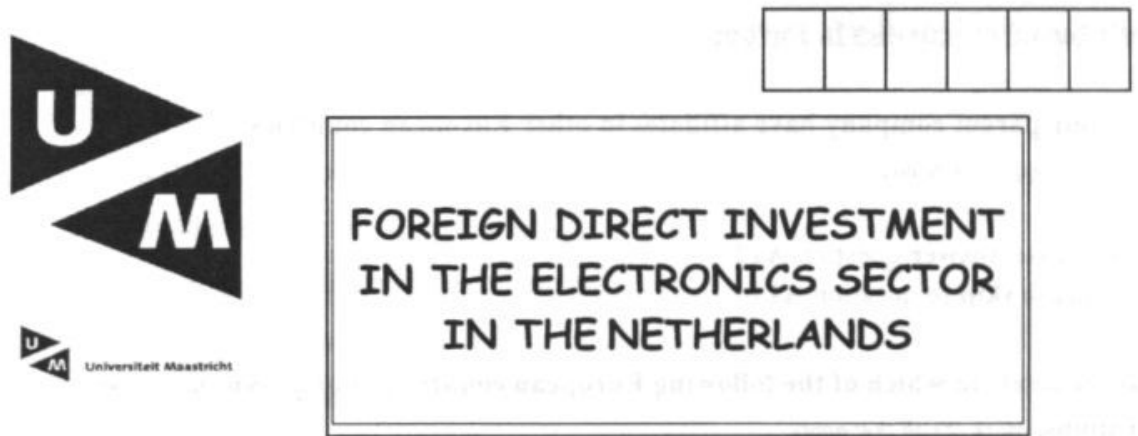

Thank you for taking the time to complete this questionnaire! Directions for filling it out are provided with each question. Most questions can be answered by marking $\mathrm{X}$ in a box. Since not all questions will apply to every company, you may be asked to skip certain questions.

Whenever we talk about the affiliate, we mean your company, at its current Dutch location. If your parent company has established more than one affiliate in the Netherlands, we would like you to answer the questions for you specific affiliate only. When we talk about your company, we mean all establishments of your parent in the Netherlands. In answering those questions, you can consider all affiliates.

If you have any questions, please contact Ms. A.E. Hogenbirk (043-3883769)

Part A

BACKGROUND INFORMATION

This section is used to inquire your affiliate and its parent. Please follow the instructions.

\section{About your company's Dutch activities}

Please fill in the appropriate answer

A1. Affiliate's name:

A2. Number of employees at this Dutch location in 1998:

A3. Revenue in 1998:

A4. Year of establishment of this affiliate in the Netherlands:

\section{About your parent company}

Please fill in the appropriate answer

A5. Name of Parent.

A6. Location of global headquarters:

A7. Location of European headquarters:

A8. Total number of affiliates in the Netherlands:

A9. Number of employees globally:

A10. World-wide revenues in 1998 :
City: Country:

City: 


\section{Your parent's business activities in Europe}

A11. Does your parent company have affiliates in other European countries? Mark $(X)$ the appropriate box

, $\square$ yes, please answer question $\mathbf{A 1 2}$ ${ }_{2} \square$ no, please skip to question $\mathbf{A 1 3}$

A12. Please indicate in which of the following European countries your parent has business operations. Mark $(X)$ all that apply.

$\begin{array}{llll}{ }_{1} \square \text { Austria } & { }_{2} \square \text { Belgium } & { }_{3} \square \text { Denmark } & { }_{4} \square \text { Finland } \\ { }_{5} \square \text { France } & { }_{6} \square \text { Germany } & { }_{7} \square \text { Greece } & { }_{8} \square \text { Ireland } \\ 9 \square \text { Italy } & { }_{10} \square \text { Luxembourg } & { }_{11} \square \text { Norway } & { }_{12} \square \text { Portugal } \\ { }_{13} \square \text { Spain } & { }_{14} \square \text { Sweden } & { }_{15} \square \text { Switzerland } & { }_{16} \square \text { The United Kingdom } \\ { }_{17} \square \text { Central and Eastern Europe } & & \\ { }_{18} \square \text { Other, please specify } \ldots \ldots \ldots \ldots \ldots \ldots \ldots \ldots \ldots \ldots \ldots \ldots \ldots \ldots \ldots \ldots \ldots \ldots \ldots \ldots \ldots \ldots \ldots \ldots \ldots \ldots \ldots \ldots \ldots \ldots \ldots \ldots \ldots \ldots \ldots \ldots \ldots \ldots \ldots \ldots \ldots \ldots \ldots \ldots \ldots \ldots \ldots\end{array}$

\section{The history of your activities in the Netherlands}

A13. Did your parent company export to the Netherlands before starting a business here?
1口 yes
${ }_{2} \square$ no

A14. Please indicate the mode of entry of your first establishment in the Netherlands. Mark (X) ONLY one.

1 $\square$ Capital participation

${ }_{2} \square$ New wholly owned subsidiary

${ }_{3} \square$ Acquisition of a Dutch supplier in 19........ (please indicate the year)

${ }_{4} \square$ Acquisition of a Dutch competitor in 19....... (please indicate the year)

${ }_{5} \square$ Joint Venture (JV) $\rightarrow$

a) please indicate home country of your partner(s)

b) please indicate your share in the JV: $\%$

${ }_{6} \square$ Other $\rightarrow$ please specify

A15. Was this first affiliate established in the electronics or related sector(s)?

10 yes

${ }_{2} \square$ no 
A16. Please indicate the most important activity conducted at this first affiliate at the time of its establishment or take-over.

Mark $(X)$ ONLY one.

Marketing, sales and after-sales services

${ }_{2} \square$ Manufacturing

${ }_{3} \square$ Logistics, distribution and warehousing

Research and Development

Regional Headquarters' activities

${ }_{6} \square$ Other $\rightarrow$ please specify

A17. Did your company undergo any of the following changes in its activities in the Netherlands after establishing its first affiliate?

$\operatorname{Mark}(X)$ the appropriate box

Expansion of the first activity (see question A16) in the existing location

${ }_{2} \square$ Expansion of the existing location, resulting in additional activities

If yes, please mark $(X)$ all additional activities

${ }_{2 \mathrm{a}} \square$ Marketing, sales and after-sales services

${ }_{2 b} \square$ Manufacturing

${ }_{2 \mathrm{c}} \square$ Logistics, distribution and warehousing

${ }_{2 \mathrm{~d}} \square$ Research and Development

${ }_{2 \mathrm{e}} \square$ Regional Headquarter activities

${ }_{3} \square$ Investments to modernise or rationalise the existing affiliate

${ }_{4} \square$ Reduction of the production capacity in the existing affiliate

${ }_{5} \square$ Construction of one or several new affiliates at a different location

${ }_{6} \square$ Investment in a new related sector/industry

${ }_{7} \square$ Investment in a new unrelated sector/industry

${ }_{8} \square$ Increased use of outsourcing

Other $\rightarrow$ please specify

${ }_{10} \square$ My company did not undergo any changes 
A18. Did your parent company change its overall strategy during the last 5 years? $\operatorname{Mark}(X)$ the appropriate box

$\square$ yes, please answer the next question (A19)

${ }_{2} \square$ no, please skip to question A20

A19. Please indicate the nature of this change:

\section{About your current business activities in the Netherlands}

A20. Please indicate the activities that are currently conducted by your company in this affiliate. Mark $(X)$ all that apply and indicate their importance (where $l=$ not important at all, and 5 is most important).

\begin{tabular}{|c|c|c|c|c|c|}
\hline , $\square$ Marketing and Sales & $\begin{array}{c}\text { Not important } \\
\text { at all } \\
1 \square\end{array}$ & $\begin{array}{r}\text { not too } \\
\text { important } \\
2 \square\end{array}$ & $\begin{array}{l}\text { neutral } \\
{ }_{3} \square\end{array}$ & $\begin{array}{c}\text { fairly } \\
\text { important } \\
4\end{array}$ & $\begin{array}{c}\text { most } \\
\text { important } \\
{ }_{5} \square\end{array}$ \\
\hline${ }_{2} \square$ Manufacturing & ${ }_{1} \square$ & ${ }_{2} \square$ & ${ }_{3} \square$ & $4 \square$ & ${ }_{5} \square$ \\
\hline${ }_{3} \square$ Logistics and warehousing & 1 & ${ }_{2} \square$ & ${ }_{3} \square$ & 4 & $s \square$ \\
\hline${ }_{4} \square$ Research and Development & 10 & ${ }_{2} \square$ & ${ }_{3} \square$ & $4 \square$ & ${ }_{s} \square$ \\
\hline${ }_{5} \square$ Regional Headquarter's activities & , & ${ }_{2} \square$ & ${ }_{3} \square$ & 4 & ${ }_{5} \square$ \\
\hline
\end{tabular}

A21. Is your affiliate acting as a regional Headquarters for Europe? $\quad{ }_{1} \square$ yes

${ }_{2} \square$ no 
A22. What is the destination of your affiliate's sales from the Netherlands?

Please mark $(X)$ all that apply.

Please also indicate which percentage share of your total sales is going to this particular country/area.

${ }_{1} \square$ Netherlands ..................................................... $\square \square \square \%$

${ }_{2} \square$ European Union country ................................. $\square \square \square \%$

${ }_{3} \square$ Parent country .............................................. $\square \square \square \%$

${ }_{4} \square$ Central and Eastern European Countries .......................... $\square \square \square \%$

${ }_{5} \square$ North America ................................................. $\square \square \square$

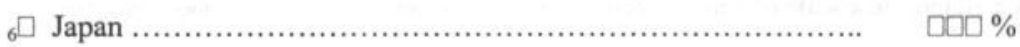

Rest of Asia ............................................... $\quad \square \square \square \%$

Rest of the World ................................................ $\quad \square \square \square$

Irrelevant, my company does not sell products from the Netherlands

\section{About the future plans of your company in the Netherlands}

A23. Does your company have any expansion plans in the next 5 years?

Please mark $(X)$ the appropriate box)

, $\square$ yes, please answer question A24 \& A 25

${ }_{2} \square$ no, please skip to section $B$ on page 7

A24. Which modes do you consider for these expansions?

Please mark $(X)$ all appropriate ones

Mergers and/or acquisitions

Expansion of the current site

$\square$ Construction of one or several new sites

${ }_{4} \square$ Other $\rightarrow$ please specify

A25. What are the reasons for your company's expansion plans?

Please indicate the most important ones 


\title{
Part B
}

\section{REASONS FOR LOCATING BUSINESS ACTIVITIES \\ IN THE NETHERLANDS}

\begin{abstract}
We would like to understand the factors that have influenced the choice for the establishment of a site or take-over of a company in the Netherlands. We have selected factors that could have been important and for your convenience we have grouped them in 4 groups, representing reasons relating to marketing, infrastructure, resource availability, and the overall economic and political situation.
\end{abstract}

Please indicate, by marking $(X)$ the appropriate box, the importance of each reason for establishing business activities in the Netherlands on a scale of 1 to 5 , where $1=$ not important at all, and $5=$ most important.

If what you consider to be your most important locational factor is not listed here, please use to "other" option (B52) to specify this factor.

\section{Marketing Factors}

Please indicate the importance of the following marketing factors on your company's decision to locate in the Netherlands:

B1. Market growth potential

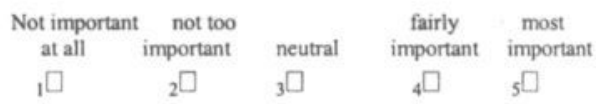

B2. Dutch market size and purchasing power of Dutch consumers

B3. Purchasing power Dutch firms

B4. Saturated home market

B5. Diversification of activities

B6. Being close to your customers

B7. Being close to suppliers

B8. Being close to key industry markets

B9. Following competition

B10. Following client

B11. Location within Benelux

B12. Easy access to European market

B13. Central location in Europe

B14. Potential client wanted a Dutch establishment

\begin{tabular}{|c|c|c|}
\hline${ }_{2} \square$ & ${ }_{3} \square$ & ${ }_{4} \square$ \\
\hline${ }_{2} \square$ & ${ }_{3} \square$ & ${ }_{4} \square$ \\
\hline${ }_{2} \square$ & ${ }_{3} \square$ & ${ }_{4} \square$ \\
\hline${ }_{2} \square$ & ${ }_{3} \square$ & ${ }_{4} \square$ \\
\hline${ }_{2} \square$ & ${ }_{3} \square$ & ${ }_{4} \square$ \\
\hline${ }_{2} \square$ & ${ }_{3} \square$ & ${ }_{4} \square$ \\
\hline${ }_{2} \square$ & ${ }_{3} \square$ & ${ }_{4} \square$ \\
\hline${ }_{2} \square$ & ${ }_{3} \square$ & ${ }_{4} \square$ \\
\hline${ }_{2} \square$ & ${ }_{3} \square$ & ${ }_{4} \square$ \\
\hline${ }_{2} \square$ & ${ }_{3} \square$ & ${ }_{4} \square$ \\
\hline${ }_{2} \square$ & ${ }_{3} \square$ & ${ }_{4} \square$ \\
\hline${ }_{2} \square$ & ${ }_{3} \square$ & ${ }_{4} \square$ \\
\hline${ }_{2} \square$ & ${ }_{3} \square$ & ${ }_{4} \square$ \\
\hline
\end{tabular}




\section{Infrastructure}

Please indicate the importance of the following infrastructural factors on the decision to locate an affiliate in the Netherlands:

B15. Harbours

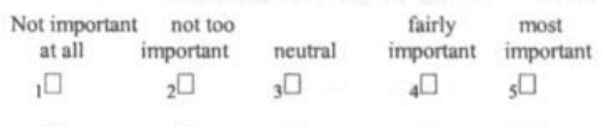

B16. Schiphol Airport

B17. Waterways

B18. Railways

B19. Motorway network

B20. Availability of truck transportation

B21. Price of road transportation

B22. Availability of warehousing facilities

B23. Price of warehousing facilities

B24. Availability of information technology and communication (ITC)-resources

B25. Availability of industrial parks

B26. Availability of office space

B27. Price of office space

\section{Resource Availability}

Please indicate the importance of the following factors on the decision to locate an affiliate in the Netherlands

B28. Lower labour costs

\begin{tabular}{|c|c|c|c|c|}
\hline $\begin{array}{c}\text { Not important } \\
\text { at all } \\
\text {, }\end{array}$ & $\begin{array}{c}\text { not too } \\
\text { important } \\
{ }_{2} \square\end{array}$ & $\begin{array}{l}\text { neutral } \\
{ }_{3} \square\end{array}$ & $\begin{array}{c}\text { fairly } \\
\text { important } \\
{ }_{4} \square\end{array}$ & $\begin{array}{l}\text { most } \\
\text { important } \\
{ }_{5} \square\end{array}$ \\
\hline${ }_{1} \square$ & ${ }_{2} \square$ & ${ }_{3} \square$ & ${ }_{4} \square$ & ${ }_{5} \square$ \\
\hline,$\square$ & ${ }_{2} \square$ & ${ }_{3} \square$ & ${ }_{4} \square$ & ${ }_{s} \square$ \\
\hline${ }_{1} \square$ & ${ }_{2} \square$ & ${ }_{3} \square$ & ${ }_{4} \square$ & ${ }_{5} \square$ \\
\hline,$\square$ & ${ }_{2} \square$ & ${ }_{3} \square$ & ${ }_{4} \square$ & ${ }_{5} \square$ \\
\hline${ }_{1}$ & ${ }_{2} \square$ & ${ }_{3} \square$ & ${ }_{4} \square$ & ${ }_{s} \square$ \\
\hline
\end{tabular}

B33. Easy access to raw materials

B34. Please indicate the importance of the proximity to important research institutes and universities (e.g. TNO, Technical universities in Eindhoven, Delft, Twente)

${ }_{1} \square \quad{ }_{2} \square \quad{ }_{3} \square$




\section{Economic and Political Situation}

Please indicate the importance of the following political and economical factors on your company's decision to locate in the Netherlands:

B35. Access to local financial resources

$\begin{array}{ccccc}\begin{array}{c}\text { Not important } \\ \text { at all }\end{array} & \begin{array}{c}\text { not too } \\ \text { important }\end{array} & \text { neutral } & \begin{array}{c}\text { fairly } \\ \text { important }\end{array} & \begin{array}{c}\text { most } \\ \text { important }\end{array} \\ 1 \square & { }_{1} \square & { }_{3} \square & 4 \square & { }_{5} \square \\ 1 \square & { }_{1} \square & { }_{3} \square & { }_{4} \square & { }_{5} \square \\ { }_{1} \square & { }_{2} \square & { }_{3} \square & { }_{4} \square & { }_{5} \square \\ { }_{1} \square & { }_{2} \square & { }_{3} \square & { }_{4} \square & { }_{5} \square\end{array}$

B36. Government subsidies

B37. Tax-regime

B38. Comprehensive legal system

B39. High costs of making and enforcing contracts

B40. Efficient bureaucracy

B41. Economic and political stability

B42. Regional economic growth

B43. Favourable customs policy

B44. Stable exchange rates

B45. Open investment climate

B46. Dutch membership of European Union (EU)

B47. Fear of import restrictions due to EU

B48. Exports to the Netherlands too expensive

B49. No good licencing partner available

B50. No good agents available

B51. Acquisition opportunity

\section{Other Factors}

B52. If your most important motivation to locate in the Netherlands is missing, please use this space to indicate these factors:
A
B 


\section{Part C \\ YOUR ISSUES OF CONCERN}

In this third section, we would like to find out which issues of concern you have that influence your current operations in the Netherlands. We have listed 34 factors that we consider to be potential hindrances in doing business in the Netherlands.

Please indicate, by marking $(X)$ the appropriate box, the importance of each issue on a scale of 1 to 5 , where $1=$ not important at all, and $5=$ most important.

If what you consider to be your most important issue of concern is not listed here, please use the "other" option (C35) to specify this factor.

\section{Labour related}

Please indicate the importance of the following labour-related factors as obstacles in doing business in the Netherlands:

C1. Social security costs

C2. Availability of technical skills

C3. Price of technical labour

C4. Availability of management skills

C5. Price of managerial labour

C6. Availability of commercial skills

C7. Price of commercial labourers

C8. Availability of unskilled labour

C9. Price of unskilled labour

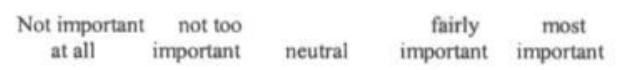

\section{Transportation- and Infrastructure-related}

Please indicate the importance of the following infrastructure-related factors as obstacles in doing business in the Netherlands:

C10. Traffic congestion

C11. Local road infrastructure

C12. Freight transportation system

C13. Public transportation system

C14. Information and Communication $\begin{gathered}\text { Not important } \\ \text { at all }\end{gathered}$
important too neutral
important $\begin{gathered}\text { fairly } \\ \text { important }\end{gathered}$ Technology (ICT) availability

C15. Transportation costs

C16. Availability of office space

C17. Availability of warehousing space

$\begin{array}{lll}{ }_{1} \square & { }_{2} \square & { }_{3} \square \\ { }_{1} \square & { }_{2} \square & { }_{3} \square \\ { }_{1} \square & { }_{2} \square & { }_{3} \square \\ { }_{1} \square & { }_{2} \square & { }_{3} \square \\ { }_{1} \square & { }_{2} \square & { }_{3} \square \\ & & \\ { }_{1} \square & { }_{2} \square & { }_{3} \square \\ { }_{1} \square & { }_{2} \square & { }_{3} \square \\ { }_{1} \square & { }_{2} \square & { }_{3} \square\end{array}$

${ }_{4} \square \quad 5 \square$

$4 \square \quad 5 \square$

$4 \square \quad 5 \square$

$4 \square \quad 5 \square$

$4 \square \quad 5 \square$ 


\section{Legislation related}

Please indicate the importance of the following legislation-related factors as obstacles in doing business in the Netherlands:

C18. Dutch labour laws

$$
\begin{array}{cccc}
\begin{array}{c}
\text { Not important } \\
\text { at all }
\end{array} & \text { not too } & \text { fairly } & \text { most } \\
\text { important } & \text { neutral important }
\end{array}
$$

C19. European business practice

C20. Environmental regulations

C21. Investment legislation

$\begin{array}{lllll}1 \square & { }_{2} \square & { }_{3} \square & { }_{4} \square & { }_{5} \square \\ { }_{1} \square & { }_{2} \square & { }_{3} \square & 4 & 4 \square \\ { }_{1} \square & { }_{2} \square & { }_{3} \square & 4 \square & { }_{5} \square \\ { }_{1} \square & { }_{2} \square & { }_{3} \square & 4 \square & { }_{5} \square\end{array}$

\section{Tax-system related}

Please indicate the importance of the following tax-related factors as obstacles in doing business in the Netherlands:

C22. Corporate tax system

C23. Personal tax system

C24. VAT system

C25. Import duties

C26. Restrictions on repatriation of profits

\begin{tabular}{|c|c|c|c|c|}
\hline $\begin{array}{l}\text { Not important } \\
\text { at all }\end{array}$ & $\begin{array}{c}\text { not too } \\
\text { important }\end{array}$ & neutral & $\begin{array}{c}\text { fairly } \\
\text { important }\end{array}$ & $\begin{array}{c}\text { most } \\
\text { important }\end{array}$ \\
\hline${ }_{1} \mathrm{D}$ & ${ }_{2} \square$ & ${ }_{3} \square$ & ${ }_{4} \square$ & ${ }_{5} \square$ \\
\hline $1 \square$ & ${ }_{2} \square$ & ${ }_{3} \square$ & ${ }_{4} \square$ & $5 \square$ \\
\hline , & ${ }_{2} \square$ & ${ }_{3} \square$ & ${ }_{4} \square$ & ${ }_{5} \square$ \\
\hline${ }_{1} \mathrm{D}$ & ${ }_{2} \square$ & ${ }_{3} \square$ & ${ }_{4} \square$ & ${ }_{5} \square$ \\
\hline${ }_{1} \square$ & ${ }_{2} \square$ & ${ }_{3} \square$ & ${ }_{4} \square$ & ${ }_{5} \square$ \\
\hline
\end{tabular}

\section{Other}

Please indicate the importance of the following remaining factors as obstacles in doing business in the Netherlands:

C27. Exchange rates

C28. Dutch banking and finance

C29. Personal and family adjustment problems

Not important not too at all important

C30. Employee housing

C31. European protectionism

C32. Small size of Dutch market

C33. Lack of suitable local business partners

C34. Differences in business attitudes

C35. Other $\rightarrow$ please specify

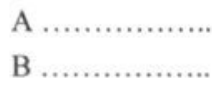

1口 2 $\quad 2 \square$

1口 $\quad 2 \square$

$\begin{array}{rr}\text { fairly } & \text { most } \\ \text { neutral important } & \text { important }\end{array}$

${ }_{3} \square \quad{ }_{4} \square \quad{ }_{5} \square$

${ }_{3} \square \quad{ }_{4} \square \quad{ }_{5} \square$

${ }_{3} \square \quad{ }_{4} \square \quad{ }_{5} \square$

${ }_{3} \square \quad{ }_{4} \quad 5 \quad 5$

$\begin{array}{llll}10 & 2 \square & 3 \square & 4 \square\end{array}$

${ }_{1} \square \quad{ }_{2} \square \quad 3 \square \quad 3 \square \quad 3 \square$

$\begin{array}{llll}1 & { }_{2} \square & 3 \square & 4\end{array}$

${ }_{1} \square \quad{ }_{2} \square \quad{ }_{3} \quad{ }_{4} \quad{ }_{5} \quad$

${ }_{2} \square \quad 3 \square$

${ }_{2} \square \quad 3 \square$
${ }_{4} \square \quad{ }_{5} \square$

${ }_{4} \square \quad 5 \square$ 


\section{Part D}

\section{ON YOUR COMPETITIVE STRENGTH IN THE NETHERLANDS}

In this last section, we would like to find out what you consider to be your most important competitive strength in doing business in the Netherlands.

Please indicate, by marking $(X)$ the appropriate box, the importance of each factor on a scale of 1 to 5 , where $1=$ not important at all and $5=$ most important. If what you consider to be your most important competitive strength is not listed here, please use to "other" option (D18) to specify this factor.

\section{Production-related factors affecting your competitive strength}

Please indicate the importance of the following production-related factors on your competitive strength:

D1. Price competitiveness

D2. Superior production technology

D3. Products tailored to the Dutch market

D4. Products tailored to the European market

Not important not too

$\begin{array}{cc}\text { fairly } & \text { most } \\ \text { neutral important important }\end{array}$

D5. Economies of scale in production

D6. Economies of scope in production

D7. Product niche market

D8. Lack of competition of product/service

D9. Dedicated suppliers

$\begin{array}{lllll}{ }_{1} \square & { }_{2} \square & { }_{3} \square & { }_{4} \square & { }_{5} \square \\ { }_{1} \square & { }_{2} \square & { }_{3} \square & { }_{4} \square & { }_{5} \square \\ { }_{1} \square & { }_{2} \square & { }_{3} \square & { }_{4} \square & { }_{5} \square \\ { }_{1} \square & { }_{2} \square & { }_{3} \square & { }_{4} \square & { }_{5} \square \\ { }_{1} \square & { }_{2} \square & { }_{3} \square & { }_{4} \square & { }_{5} \square \\ { }_{1} \square & { }_{2} \square & { }_{3} \square & { }_{4} \square & { }_{5} \square \\ { }_{1} \square & { }_{2} \square & { }_{3} \square & 4 \\ { }_{1} \square & { }_{2} \square & { }_{3} \square & { }_{4} \square & { }_{5} \square \\ { }_{1} \square & { }_{2} \square & { }_{3} \square & { }_{5} \square\end{array}$

\section{Organisation-related factors affecting your competitive strength}

Please indicate the importance of the following organisation-related factors on your competitive strength:

D10. International experience of parent

D11. Marketing skills

D12. Headquarter support

D13. Independence of headquarters

D14. Knowledge of the Dutch market

D15. Good distribution channels

at all important neutral important important

D16. Local government contacts

$\begin{array}{lll}{ }_{1} \square & { }_{2} \square & { }_{3} \square \\ { }_{1} \square & { }_{2} \square & { }_{3} \square \\ { }_{1} \square & { }_{2} \square & { }_{3} \square \\ { }_{1} \square & { }_{2} \square & { }_{3} \square \\ { }_{1} \square & { }_{2} \square & { }_{3} \square \\ { }_{1} \square & { }_{2} \square & { }_{3} \square \\ { }_{1} \square & { }_{2} \square & { }_{3} \square \\ { }_{1} \square & { }_{2} \square & { }_{3} \square\end{array}$

D17. Ability to raise capital at preferential rates 
D18. If what you consider to be your most important competitive strength is not mentioned here, please use the space below to indicate this (these) missing factor(s)

You are finished with the questionnaire.

Thank you very much for your co-operation and the time you spent completing this questionnaire!

Company code

Please return the questionnaire to

Ms. A.E. Hogenbirk

by mail with the included return envelope (no stamps needed) to:

\section{Universiteit Maastricht \\ T.a.v. A.E. Hogenbirk \\ Antwoordnummer 2 \\ 6200 VB Maastricht}

or by fax $(043-3884893)$

If you have lost the envelope and want another, you can call $043-3883769$.

If you would like to receive a summary with the results of this survey, please fill in your contact address here: 
Appendix C

\section{QUESTIONNAIRE METHODOLOGY}

\section{C.1 Introduction}

This appendix discusses the methodological issues related to the questionnaire used in part of this study on the determinants of FDI activity in the Netherlands. We first look at the reasons for using a survey for part of this study in Section two. Then we review the process of address collection in Section three. After that, the questionnaire design and the pre-test of the questionnaire are discussed in Sections four and five respectively. This is followed by a description of the mailing in Section six. At the end, an overview of the result of the mailing is given.

\section{C.2 Survey research}

The choice of an adequate method of data collection is based on the type of research problem investigated. Research can either be cross-sectional of longitudinal. For Chapters five and six of this study, we apply a cross-sectional design that involves the collection of information from any given sample of population elements only once (Malhotra 1996, Dillon et al. 1990) and therefore does not convey variation in opinion over time (Cryer and Miller 1994). Longitudinal research on the other hand, provides an in-depth view of the situation and the changes that take place over time (Malhotra 1996). However, response bias and representative sampling are serious problems in longitudinal research. Furthermore, it implicitly requires long data collection periods. Given the limited time period and the objectives of our study, we decided that cross-sectional research would adequately provide the required information.

Figure $\mathrm{Cl}$ gives on overview of possible research data. Most empirical studies on FDI use secondary (i.e. existing) data for their analyses (see for example Gomes-Casseres 1990, Grosse and Trevino 1996, Culem 1988, Bajo-Rubio and Sosvilla-Rivero 1994, Aristotelous and Fountas 1996). Several studies, however, have acknowledged the usefulness of primary data (see for example Bell 1996, Agarwal and Ramaswami 1992, Kim and Hwang 1992) because one can control the relevance of the collected data (Cryer and Miller 1994). Primary data can be either qualitative or quantitative. Qualitative research provides insights and understanding of the problem setting and is used to develop an initial understanding of a problem (Malhotra 1996). It is usually done by investigating a focus group, or conducting in depth interviews. The sample consists of just a few non-representative cases and the analysis is usually non-statistical. Qualitative 
research, on the other hand, is used to quantify the data and generalise the results from the sample to the population (Malhotra 1996). It is used to recommend a final course of action. The sample consists of a large number of representative cases. The data are collected in a structured way and the analysis is conducted using statistics.

Figure C1: A classification of research data

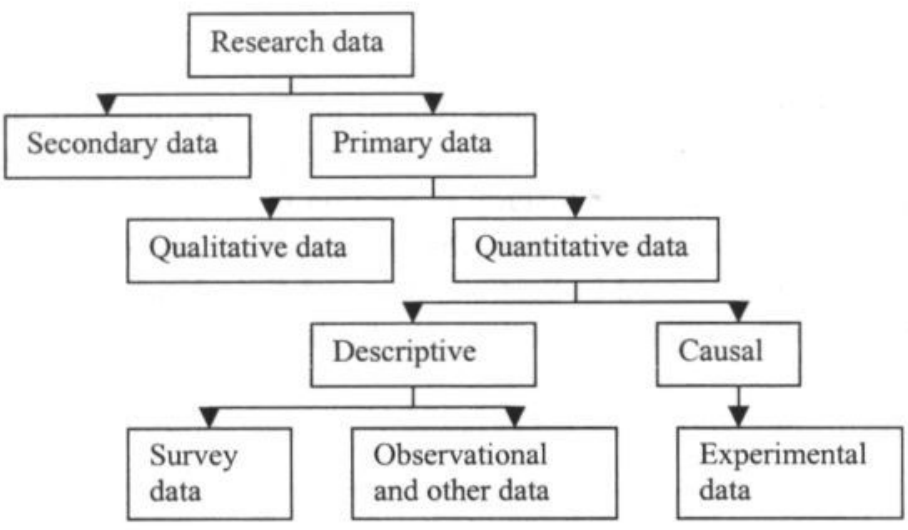

Source: Malhotra (1996)

For this study, we want to give a descriptive analysis. We therefore focus on quantitative data. We used a non-experimental as opposed to an experimental research method. With the later method, independent variables are manipulated to see the effect on a dependent variable, either in a field or a laboratory environment (Dillon et al. 1990, Cryer and Miller 1994). This is not possible in our study. We therefore have to rely on a nonexperimental design, where we first observe the outcome and then attempt to find the causal factor that presumably has caused the effect (ex post facto) (Dillon et al. 1990).

Non-experimental research designs can consist of observation as well as survey methods of data collection. Survey research is a set of orderly procedures specifying what information is to be obtained and from whom and how. We chose to do a survey for this study since the firms investigated are too many and too widely dispersed to contact all of them. The effort to approach all foreign firms in the Netherlands would be massive, costly, time-consuming, and prone to mistakes. We also chose survey research because we want to generalise about the existing behaviour of firms, in one particular sector. While behaviour of firms could adequately be assessed by means of observation, the reasons underlying this behaviour can hardly be uncovered through observational methods. Survey research allows researchers to test hypotheses and distinguish between subgroup differences. 
Surveys have important characteristics (Backstrom and Hursh-César 1981). Survey research is systematic. It follows a specific set of rules. It is impartial. It selects units of a population without prejudice or preference. It is representative. It includes units that together are representative of the problem under study and the population affected by it. Relative to other methods, it allows researchers to gather information about a large group of people in many different places in a short time. It is theory-based. Its operations are guided by relevant principles of human behaviour and by mathematical laws of probability. It is quantitative. It assigns numerical values to non-numerical characteristics of a population. It therefore allows researchers to collect perceptual data on a large scale. We can use it to test the factors that have influenced the actual choice to locate an affiliate in a small country such as the Netherlands. It is self-monitoring. Its procedures can be designed in ways that reveal any unplanned or unwanted distortions that may occur. Survey research is contemporary. It is current, more than historical, fact-finding. And it is replicable. Other people using the same method in the same way can get essentially the same results.

Figure C2: A classification of survey methods

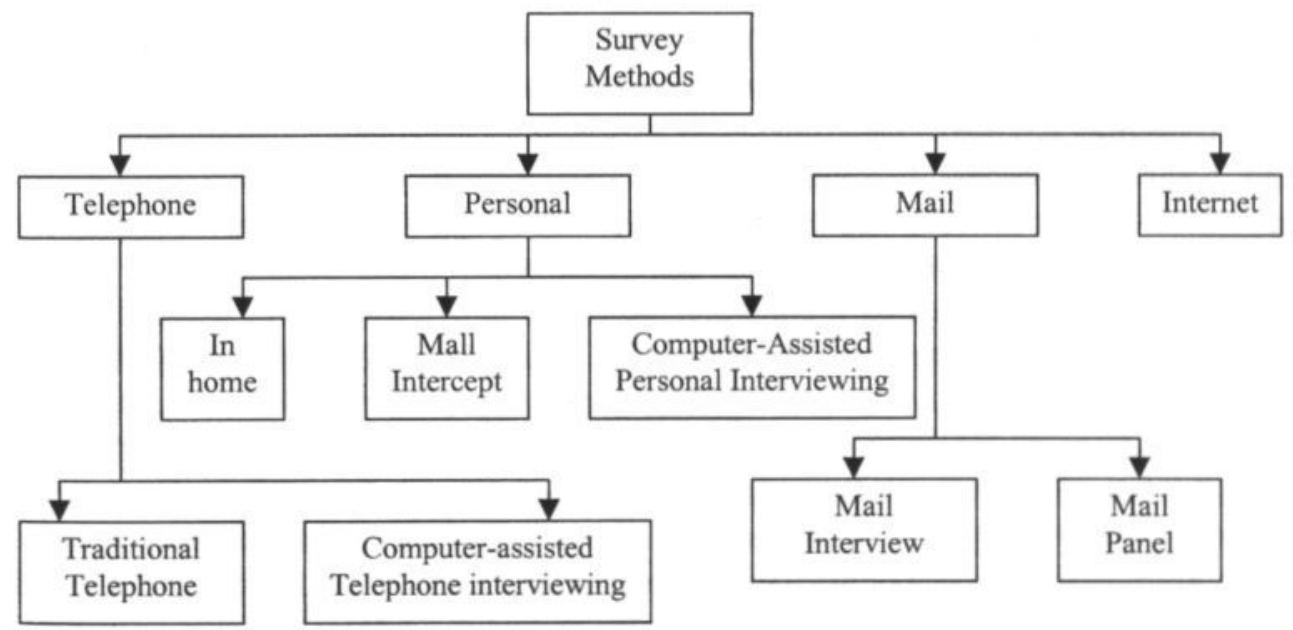

Source: adapted from Malhotra (1996)

A classification of survey methods is given in Figure C2. Survey methods are generally classified into mail, Internet, telephone, and personal surveys (interviews, f.e. in home and mall-intercept interviews). They differ with respect to flexibility in data collection, diversity of questions, use of physical stimuli, sample control, response rate, potential interviewer bias, and degree of obtaining sensitive information (Malhotra 1996). In this 
study we apply a mail survey to gather the required data. Mail and Internet survey research differs from informal techniques such as interviews (either personal or telephone) and observations in that it is a more systematic and impartial means of getting information. It is also less demanding on time and money. Mail panels consist of large and nationally representative samples of households that have agreed to participate in periodical mail questionnaires, product tests, and telephone surveys (Malhotra 1996). In our study, no such panel existed. Our first concern, therefore, was the creation of a valid mailing list.

\section{C.3 Address collection and sampling}

No complete overview of foreign firms active in the Netherlands exists. We combined several sources with addresses to get a clear picture of all foreign affiliates in the Netherlands (see Chapter three). For the initial analysis on agglomeration and clustering, we did not distinguish between sectors. However, due to financial and time constraints the survey only included firms that were active in the electronics and related sectors. The electronics sector was selected because of its importance to the Dutch economy (see also Chapter one).

The original sample consisted of 633 firms that were active in the following SIC-code sectors: 357 (computer equipment), 36 (electrical and electronic equipment), 3825 (instruments for measuring and testing electricity and electrical signals), 3829 (measuring and controlling devices), 5044 (wholesale office equipment), 5045 (wholesale computers and computer peripheral equipment excluding software), 506 (wholesale electrical apparatus and appliances), and 5084 (wholesale industrial machinery and equipment). In some cases firms in the SIC sector 422 (warehousing and storage) were included, whenever we were sure that these warehousing activities were done by an electronics company. Quite a number of the firms included in the directories reported that their main classification should be in the holding offices category $(6711,6719)$. We have included only those firms that also reported some activities in the mentioned SIC-codes. Whenever possible these firms activities were checked using the Dutch REACH database (REview and Analysis of Companies in Holland) information. In some cases this resulted in firms being excluded from the sample because their primary and secondary activities reported in the online REACH was not in the electronics and related sectors ${ }^{1}$.

We acknowledge the fact that lists of firms are never complete, up-to-date, and fully accurate. We therefore have combined several sources to make the list as extensive as possible. First of all, we have used the 1996 and 1997 Dun \& Bradstreet CDs to locate a

\footnotetext{
${ }^{1}$ The Dutch Camber of Commerce uses a method to classify the firms registered by main activity/sector that is slightly different from the standard SIC-classification because it is more detailed (up to six digits). The coding system is called Bedrijfsindeling Kamers van Koophandel 1995 (BIK'95). For our analysis we have included firms conducting activities in the following BIK'95-codes: 2923, 2971, 30, 31, 32,331 (if electronic instruments), 3320, 3330, 511502, 511401, 5143, 51482, 5164, 51654, 51657, 51658.
} 
large number of foreign firms conducting activities in the Netherlands (we included those firms that were present in the Netherlands but whose parent and global ultimate owner were foreign). These addresses have been updated using the printed version of Dun's "foreign firms in the Netherlands 1999". Furthermore, extensions have been made by adding firms from the ABC-Directory of firms in the Netherlands (1999) that had not previously been found. Added to this list were Japanese affiliates known and reported by JETRO. To check the information achieved in this way, we traced all firms in the list on the 1999 REACH-A database. Missing data were added and addresses were verified.

The sample firms' existence was cross-checked using the PTT (Dutch Postal Services) $\mathrm{CD}$ with addresses and telephone numbers. Of the 633,531 could be found on the same location this directory as well. Occasionally the addresses of the firms could be updated on the basis of the information listed in this directory (particularly if firms had left their original location for a new one somewhere else in the Netherlands). The remaining 102 firms were only sent a questionnaire in the first round. Most of those questionnaires were returned by the PTT indicating that the firm had left and no forwarding address was known (see 5.3.5).

\section{C.4 Questionnaire design}

Data for parts of this thesis were collected at the level of the firm, preferably from the $\mathrm{CEO}$, using a questionnaire. Any questionnaire has three specific objectives (Malhotra 1996). First it must translate the information needed into a set of specific questions that the respondent can and will answer. Our questionnaire has been designed in such a way that quick answering is possible and few open-ended questions have been included (see Appendix B). The questionnaire contains 3 kinds of questions. First of all, facts are asked. How long has the firm been in the Netherlands, what is its home country, how many affiliates does its parent have in the Netherlands, is it present in any other European country etc. Secondly, we ask for their opinion on the reasons to locate in the Netherlands. We also investigate their views on potential or actual problems in doing business in the Netherlands. Thirdly, we want to find out their establishment behaviour, and their expected future behaviour. How did their activities in the Netherlands change, and do they expect even further changes in the near future? In designing the questionnaire we consulted several people for feedback. We also related our issues to previous studies on inward FDI.

Second, a questionnaire must uplift, motivate, and encourage the respondent to become involved in the interview, to cooperate, and to complete the questionnaire. In designing the questionnaire, a researcher should strive to minimise respondent fatigue, boredom, non-response, and incompleteness. We tried to achieve this by organising the questions into four sections (see Appendix B), numbering the questions in each part. We asked questions about the general background of the firm, the reasons for locating in the Netherlands, problems associated with doing business there and finally, their perception 
of the competitiveness of this particular affiliate in the Netherlands. Since mail questionnaires have to be self-administered, clear instructions are given in boxes, indicating the importance of the information. Furthermore, we restricted the length of the questionnaire and indicated the expected time involved in filling in the boxes in the accompanying letter.

Third, a questionnaire should minimise response error. We tried to achieve this by structuring most questions as fixed-response questions, usually with multiple choice answers offering several alternatives. Structured questions are easy to use because people can simply circle the right answer, or check the right box. We have chosen questions with limited response categories rather than open-ended questions because they result in greater uniformity of responses and, thus, in greater ease of data processing than openended questions because structured questions can be pre-coded by assigning a unique number to each answer. Although they take away the personal flavour of respondents' answers, we try to encourage them to include this information if necessary in the 'other'option.

Most questions required the respondent to score on a 5-point Likert-type scale. The Likert-scale's main strength is that is allows respondents to express the intensity of their feelings (Dillon et al. 1990, Malhotra 1996). Moreover, its ease of construction and the simplicity of respondent directions are considered true advantages of the scale, particularly in the case of mail surveys (Malhotra 1996). Since we expected that respondents could feel neutral about statements included in the questionnaire, we opted for an odd number of response options (Dillon et al. 1990, Malhotra 1996), including a neutral position in the middle. That way, we balance the number of favourable and unfavourable response options in order to reduce response bias (Green et al. 1988).

In addition to those questions, several questions were asked that had just two categories (yes/no) and some open ended questions were added, particularly to inquire about any missing reasons or future plans. For most categories we included an "other, please specify"-option in case the specific answer of this particular firm has not been listed. In total, 129 questions related to locating in the Netherlands were tested.

The physical characteristics of a questionnaire can greatly affect the accuracy of the information obtained. When it looks shabby, respondents might think that they study is not important and might refuse to co-operate as a result (Malhotra 1996). We have tried to design a layout that encouraged respondents to participate. Furthermore, we tried to prevent errors by separating items by white lines and giving clear instructions in text boxes immediately above the corresponding questions. Since all firms in our sample were foreign establishments, we designed the questionnaire in English.

\section{C.5 Pre-testing of questionnaire}

A pre-test is usually done in advance of the large-scale survey, to get insights into the people and problems under study as a basis for improving the chances of achieving a 
successful survey (Dillon et al. 1990, Malhotra 1996). Although surveys appear to be easy in use, there are many problems associated with them. Some of the potential problems include: questions that can be interpreted in multiple ways, terms used are misunderstood by respondents, the response rate may be (too) low, and respondents may be guided to outcomes ex-ante preferred by the researcher. Item pre-testing is considered as testing items on a small sample for the purpose of improving these items by identifying and eliminating potential problems.

Out of all firms in the questionnaire sample with one or more affiliates in the electronics or related sectors, we selected 2 firms for the pre-test of the questionnaire. Taking these test firms from the sample ensures that their characteristics are similar to those in the final data collection (Malhotra 1996). One firm did actually have more than one activity in the Netherlands, while the other one has just one establishment, though is considering the take-over of a second. Both firms were contacted by phone to ask for an interview with the general manager. One of the firms allowed a discussion with the financial manager, since the general manager was too busy. These interviews were conducted 2 weeks in advance of the actual survey.

The items were pre-tested with respect to layout, content, item sequence, item wording, and item difficulty. Respondents were asked to complete the questionnaire and comment on the questions. The pre-test resulted in only minor changes to the original questionnaire, in particular to enhance the logic of the questions and facilitate its use. We also got a fair idea of the actual time involved in filling in the questionnaire. On average, we expect that it takes about 20 minutes to complete the list of questions.

\section{C.6 Mailing of the questionnaire}

\section{C.6.1 First round of questionnaire}

Given the sample size, we have chosen to send the questionnaire by mail, mid November 1999. With the questionnaire a letter asking for firms' participation was sent, whenever possible directed to the managing director. This letter was typed on university paper. Also included in the mailing was a pre-paid return envelope. In that way the only costs involved in the survey for the actual firm was the time spent on answering the questions. To further increase participation, a summary of the results was offered to the participating firms. To be able to follow the responses, we gave every firm a unique code, related to their SIC-activity. This code was printed on the letter, the second, and the last page of the questionnaire.

Table $\mathrm{C} 1$ summarises the results of the first mailing. 633 questionnaires were sent. 37 firms returned a completed questionnaire. 53 firms gave some kind of reaction (either by mail, fax, phone, or e-mail) as to why they could not participate. Sixteen firms indicated that they did not want to participate, for various reasons including lack of time, an overabundance of requests to participate in scientific research, recent reorganisation, 
take-over or move. One firm indicated that they had been in the Netherlands too long (more than 40 years) to be able to answer the questions.

Seven firms indicated that the addressed firm was no longer foreign but now for instance acting as an independent Dutch agent for the previous mother. Two of them turned out to be a Dutch firm with foreign establishments that were wrongly classified as being foreign in the directories used for this study. Seventeen companies had had changes in management and the person addressed in the letter was no longer with the firm. Whenever possible the current manager was traced and the letter was sent again (considering it a repeated first mailing). If no new manager was found, the letter was sent again addressing "general manager" without a name. The "other" category (13 firms) comprises several remaining reasons. Eight firms were not conducting activities in the electronics or related sectors. Another one went bankrupt recently. Two firms indicated that no investment decisions were taken locally. All decisions were made by the parent and therefore suggested we would contact them. One manager indicated that he did not have time to answer the questionnaire.

Table C1 Response to the first mailing (633 letters sent)

\begin{tabular}{|l|c|c|c|c|c|c|c|}
\hline & $\begin{array}{c}\text { Returned } \\
\text { question- } \\
\text { naire }\end{array}$ & $\begin{array}{c}\text { Left } \\
\text { location }\end{array}$ & $\begin{array}{c}\text { Not (longer) } \\
\text { foreign firm }\end{array}$ & $\begin{array}{c}\text { Addressed } \\
\text { person no } \\
\text { longer there }\end{array}$ & $\begin{array}{c}\text { Don't } \\
\text { want to } \\
\text { participate }\end{array}$ & Other & $\begin{array}{c}\text { No res- } \\
\text { ponse } \\
\text { at all }\end{array}$ \\
\hline $\begin{array}{l}\text { Response } \\
\text { by Nov. } \\
30^{\text {th }}\end{array}$ & 37 & 75 & 7 & 17 & 16 & $\begin{array}{c}13 \\
(8 \text { not } \\
\text { electronics })\end{array}$ & 468 \\
\hline
\end{tabular}

We expected that 102 firms had left (or perhaps recently relocated in) the Netherlands, since their known location was not confirmed in the PTT (Dutch postal services) directory. The PTT returned 75 questionnaires because the firms had left the location. Thirty-two of those were included in the sample of 102 firms for which we were not sure whether they still existed or not. However, many new firms (43) were added to the 'relocated' list, resulting in a total of 145 . We checked if any of those firms had relocated in the Netherlands and managed to find 59 new locations. Those firms were approached again (considering this second mailing to be a first). Nineteen of those firms did in the end participate in the questionnaire. The other 96 were considered to have left the Netherlands and were not tried again.

\section{C.6.2 Reminder}

Typically, response rates to mail questionnaires are low, no more than 10 percent if no follow up is made (Dillon et al. 1990). However, multiple mailings are a method to increase the response rate. Two weeks after the initial mailing, we therefore sent out another questionnaire to the firms that did not respond to the first mailing, excluding the 
firms we could not find in the PTT directory (96 in total). At the same time we sent out a first mailing to the relocated firms (59) and the firms whose managers had changed (17). The results of this mailing (464 letters in total) are presented in Table C2. Twenty-three firms did return their completed questionnaire, but in one case the same firm had responded to the first and second mailing (their response had crossed our new call. We did not include this extra questionnaire). Another 11 were returned by the Postal Services indicating that the company no longer existed (some of those were actually from the first mailing to the relocated firms, they had left their new locations as well).

Seven firms contacted us (either by mail of phone) to notify that they were no longer foreign and sixteen indicated that they did not conduct activities in the electronics industry. Ten firms did not want to participate. Five firms could not participate for various reasons including bankruptcy, and the fact that their decision making process is not independent from that of the parent. One firm indicated that business in the Netherlands had been too difficult due to an existing cartel.

Since we had collected fax-numbers of most firms as well, we decided to send a reminder fax to non-responding firms before Christmas. As a response to the fax reminder four companies indicated that they were not doing any electronics activities. Two firms indicated that they did not want to participate. Twenty-one more completed questionnaires were returned in the following weeks (also partly due to the second mailing to firms that had relocated, sent just before Christmas. These responses were generally 2 weeks later). Another 11 firms replied by phone or e-mail asking for another copy of the questionnaire. Six of those were returned during January 2000. The other 5 decided not to co-operate after all and are therefore included in the firms that did not want to participate. In the first three months of 2000 occasionally the postal services still returned questionnaires from firms that had left their location. Another thirteen came back for that reason, resulting in 120 firms that had disappeared.

Table C2 Response to the second mailing (464 letters)

\begin{tabular}{|l|c|c|c|c|c|c|c|}
\hline & $\begin{array}{c}\text { Returned } \\
\text { question- } \\
\text { naires }\end{array}$ & $\begin{array}{c}\text { Left } \\
\text { location }\end{array}$ & $\begin{array}{c}\text { No longer } \\
\text { foreign firm }\end{array}$ & $\begin{array}{c}\text { Not in } \\
\text { electronics }\end{array}$ & $\begin{array}{c}\text { Don't } \\
\text { want to } \\
\text { participate }\end{array}$ & $\begin{array}{c}\text { Other } \\
\text { response } \\
\text { at all }\end{array}$ \\
\hline $\begin{array}{l}\text { Response } \\
\text { by Dec. } \\
15^{\text {th }}\end{array}$ & 22 & 11 & 7 & 16 & 10 & 5 & 393 \\
\hline
\end{tabular}

\section{C.6.3 Follow-up}

We have followed up on the questionnaire by calling a sample of non-responding firms to try to persuade them to participate, and if not, to find out their reason for not participating. The main reasons for non-response include:

* Lack of time

* An overabundance of request to participate in scientific or other research 
* Principle matter never to answer any questionnaires

* Recent reorganisation

* Have been in the Netherlands for so long, that they no longer consider themselves foreign

Furthermore we have sent 'thank you'-faxes to the firms that did participate and after the data analysis we sent them short overviews of the most important results. In some cases we have used telephone interviews or faxes to verify answers given by the respondents or check for any missing values.

\section{C.7 Conclusions}

Table C3 summarises the results of the questionnaire. Initially 633 firms were approached to participate in the study. Of those, $120(19.0 \%)$ turned out to no longer be in the Netherlands. Another 28 firms indicated that they were not active in the electronics sector. Fourteen firms were no longer foreign (or never had been). They were taken over by Dutch firms, or had only briefly used a foreign base for tax reasons. Two firms notified their recent bankruptcy. Therefore the total sample for the study is reduced to $633-120$ (gone) -28 (not in electronics) -14 (not foreign) -2 bankrupt $=469$ present foreign establishments. Of those we got 127 responses $(27.1 \%)$ of which 86 returned a completed questionnaire, representing $18.3 \%$ of total present foreign establishments.

Table C3 Results of the study (original population $=633$ )

\begin{tabular}{|l|c|c|c|c|c|c|c|}
\hline & $\begin{array}{c}\text { Returned } \\
\text { question- } \\
\text { naires }\end{array}$ & $\begin{array}{c}\text { Left } \\
\text { location }\end{array}$ & $\begin{array}{c}\text { Not (longer) } \\
\text { foreign firm }\end{array}$ & $\begin{array}{c}\text { Not in } \\
\text { electronics }\end{array}$ & $\begin{array}{c}\text { Don't want } \\
\text { to } \\
\text { participate }\end{array}$ & $\begin{array}{c}\text { Other } \\
\text { response } \\
\text { at all }\end{array}$ \\
\hline $\begin{array}{l}\text { Response } \\
\text { after 2 } \\
\text { mailings and } \\
\text { a fax }\end{array}$ & 86 & 120 & 14 & 28 & 34 & 9 & 342 \\
\hline
\end{tabular}

Table $\mathrm{C} 4$ shows the home countries of the firms responding to the questionnaire and those in the total sample. Overall the match is quite well. German, Belgian, and Japanese firms make up 25.6, 4.7, and 9.2 percent respectively of the total sample and 24.4, 5.8, and 10.5 percent respectively of the responding firms. There are however two irregularities. Firms from the United Kingdom are underrepresented. They make up 11.3 percent of the sample but only 5.8 percent of the responding firms. The opposite is true for the US firms. Although they make up 24.7 percent of the sample, they make up 29.1 percent of the responding firms. 
Table C4 Representativeness of the response

\begin{tabular}{|c|c|c|c|c|}
\hline Country & Response & $\begin{array}{l}\text { Share of country } \\
\text { in total response }\end{array}$ & Total sample & $\begin{array}{l}\text { Share of country } \\
\text { in total sample }\end{array}$ \\
\hline Australia & & & 1 & 0.2 \\
\hline Austria & & & 3 & 0.6 \\
\hline Belgium & 5 & 5.8 & 22 & 4.7 \\
\hline Canada & & & 2 & 0.4 \\
\hline Denmark & 3 & 3.5 & 12 & 2.6 \\
\hline Finland & 1 & 1.2 & 2 & 0.4 \\
\hline France & 5 & 5.8 & 24 & 5.1 \\
\hline Germany & 21 & 24.4 & 120 & 25.6 \\
\hline Hong Kong & & & 2 & 0.4 \\
\hline Ireland & & & 1 & 0.2 \\
\hline Israel & 1 & 1.2 & 2 & 0.4 \\
\hline Italy & 1 & 1.2 & 6 & 1.3 \\
\hline Japan & 9 & 10.5 & 43 & 9.2 \\
\hline Liechtenstein & & & 0 & 0.0 \\
\hline Luxembourg & & & 2 & 0.4 \\
\hline Norway & & & 1 & 0.2 \\
\hline South Korea & & & 2 & 0.4 \\
\hline Sweden & 1 & 1.2 & 10 & 2.1 \\
\hline Switzerland & 7 & 8.1 & 33 & 7.0 \\
\hline Taiwan & 2 & 2.3 & 12 & 2.6 \\
\hline United Kingdom & 5 & 5.8 & 53 & 11.3 \\
\hline United States & 25 & 29.1 & 116 & 24.7 \\
\hline Total & 86 & & 469 & \\
\hline
\end{tabular}




\section{Appendix D}

\section{DETERRENTS IN DOING BUSINESS IN THE NETHERLANDS}

\section{D.1 Introduction}

It is clear from this thesis and the results of the questionnaire study conducted for this thesis, that many factors make the Netherlands an attractive location for foreign firms. A large number of multinational enterprises (MNEs) (over 7000), therefore, has established affiliates there, with a considerable majority favouring the Randstad area. These foreign affiliates contribute to the economic prosperity of the Netherlands (see for instance Beers et al. 1999, Wintjens 2001 etc.). As we have seen in Chapter one, inward foreign direct investment (FDI) can offer the host economy gains in terms of employment, technological spillovers, and linkages with local producers.

Most studies on FDI, therefore, concentrate on the attractiveness of nations and not so much on the problems that foreign firms face when conducting business activities from a location outside their home market. However, these problems should be monitored carefully because eventually, if large enough, they could lead to the divestment ${ }^{1}$ of the foreign activity. It is increasingly recognised that divestments are not exclusively associated with declining industries (Boddewyn 1983). They can take place in each transition in the life-cycle. Exits even appear to be more likely in highly innovative environments than in mature, low-innovative industries, particularly in the short run (Audretsch 1994). While considerable entry may occur in high-technology industries, many of these firms will quickly exit again as well (Acs and Audretsch 1989) ${ }^{2}$.

\footnotetext{
${ }^{1}$ Although FDI represents a long-term commitment to a foreign operation, divestments seem nevertheless to be quite common (Benito 1997). Barkema et al. (1996) have shown that of 225 investments made by 13 large non-financial Dutch multinational enterprises (MNEs) between 1966 and 1988, just over half of them were still in existence in 1988. The other operations had exited the market. Similarly, Benito (1997) shows that more than half (108) of a sample of foreign subsidiaries owned by Norwegian companies in 1982 (182) were divested within a period of ten years. Mata and Portugal (2000) find that for a sample of 1033 foreign firms in Portugal the average exit rate over the period 1983-1989 is 5.8 percent annually. These results confirm the general perception that FDI is mobile and "footloose"1 and that MNEs will relocate activities very quickly if the results are disappointing. Booth (1999) emphasises that this is particularly true for high tech firms.

${ }^{2}$ Kleijweg and Lever (1996) show that exits in the Dutch electrical products industry were on average 4.4 percent annually over the period 1986-1992. This relatively high exit rate (only surpassed by wearing apparel (13.5 percent), and textiles ( 5.0 percent) in the same period) is matched by a high rate of new entries ( 10.0 percent annually) emphasising the dynamics of the high-tech industry that is the focus of our questionnaire study.
} 
The most important reason for closing down an affiliate will naturally be low profits or even losses (Siegfried and Evans 1994). Disappointing business results can be due to firm-specific factors such as management and coordination problems (Benito 1997), age (Audretsch 1991), size of the investment (Hall 1987, Shapiro and Khemani 1987), and governance mode (Benito 1997, Mata and Portugal 2000). Apart from these firm-specific factors disappointing profits can also be due to (changes in) the economic and political environment in the host country (Weston 1989, Hamilton and Chow 1993). Divestitures are rarely related to preplanned change in corporate strategy, but are usually responses to environmental stimuli that were not anticipated (Boddewyn 1983).

It is therefore important for a host economy to determine the factors that complicate doing business there and might result in divestments. Tracking the actual divestment reasons is not possible within the current study $^{3}$ for the Netherlands. Firms that have left the market can not easily be traced and exits are often regarded as failures and companies therefore treat them with secrecy (Hamilton and Chow 1993). Internal firm-specific problems are also beyond the scope of this study. However, we did conduct an investigation of the "environmental" problems that might hinder foreign managers in running their Dutch affiliate. These problems indicate potential deterrents to doing business in the Netherlands and possible reasons to exit. Policy measures - aimed at keeping the Netherlands competitive and attractive for foreign firms - could target solutions to these problems.

The focus in this appendix therefore is on the factors that hinder foreign business activity in the Netherlands. Section 2 discusses the methodology and the data. Section 3 presents the results of the questionnaire study conducted among foreign electronics firms. Section 4 groups the 34 items of the questionnaire using factor analysis. The eight resulting factors can be used to target investment policies enhancing the attractiveness of the Netherlands. Section 5 discusses the results of the questionnaire. Conclusions are given in Section 6.

\section{D.2 Methodology and data}

We used a questionnaire study to investigate the deterrents to doing business in a high tech industry (electronics) in the Netherlands. A description of the questionnaire methodology is given in Chapter five and Appendix C. The questionnaire itself is presented in Appendix B. Section C of the questionnaire asked the manager to rate the importance of 34 potential deterrents on a five-point Likert-scale ranging from $1=$ not important at all to $5=$ most important. The 34 factors were selected on the basis of available information of previous studies conducted among foreign establishments in the Netherlands (KPMG 1996a, 1996b, 1998). They cover all seven groups of location factors mentioned in Figure 5.1 in Chapter five. For the present analysis, we have

\footnotetext{
${ }^{3}$ The main focus of this study was on the factors that make the Netherlands an attractive host location.
} 
classified these factors in five groups of issues of concern: labour-related, transportation and infrastructure, legislation-related, tax-related, and other factors.

We have to be careful in interpreting the results because we investigated the opinions of managers from MNEs that are currently present in the Dutch market. They will most likely emphasise other problems than firms that are considering entry. Furthermore, the results do not allow the testing of the particular reason to leave the Netherlands for the exits that have occurred. However, they can be seen as an exploration that indicates directions for future research.

Eighty-six firms participated in the questionnaire study. Details on those firms are given in Table 5.2 in Chapter five. Seventy of the 86 firms that returned the questionnaire (81\%) first exported to the Netherlands from their home country. Through their exports they familiarised themselves with Dutch business practices and customer needs. After this initial contact, they decided to establish an affiliate in the Dutch market. Sixty-three percent of the establishments $(n=54)$ were wholly-owned subsidiaries while 14 firms entered by acquiring either their supplier or local competitor. The majority of the newly established foreign affiliates $(89 \%)$ mentioned that marketing and sales were their most important activity. After some time, additional functions (such as manufacturing, logistics and distribution, and regional headquarter activities) were added, resulting in an increasing embeddedness of the affiliate in the Netherlands. Sixty-nine percent of the participating firms currently have expansion plans, mostly through mergers and acquisitions (24\%) or expansions at the current site (35\%).

Even though our results indicate that most foreign affiliates in the sample are planning to stay in the Netherlands and even consider additional activities, we do investigated their problems in doing business in the Netherlands as well. We follow the same methodology as in Chapter five. We first focus the analyses of the deterrents to doing business in the Dutch electronics industry on the entire group of respondents. Then, we analyse the differences in problems between groups of affiliates organised by specific characteristics such as sales focus, size, age, and home country.

\section{D.3 Deterrents to investments}

Overall, one could say that most managers have a positive attitude towards doing business in the Netherlands. Table D.1 gives on overview of the 34 potential issues of concern listed in the survey and the average response of the 86 firms that returned the questionnaire. Only ten out of the 34 factors mentioned are more or less problematic for the average investor (mean $>3.00$ ).

From the table it is clear that the most important problems are infrastructure or resource related. Traffic congestion stands out as the biggest problem (3.84). It is a nuisance for both foreign and indigenous firms. Related to this problem are concerns about the local road infrastructure (3.21) and the transportation costs (3.01). The second group of problems that stands out is the availability of skilled labour, technical (3.38), commercial 
(3.34), and managerial (3.24). The price of technical labour is also a problem for most managers (3.22). Social security costs are listed as the third most important issue of concern of foreign managers (3.36). Combined with Dutch labour laws (3.02) and relatively high personal taxes (3.31), the overall availability and cost of the resource (skilled) labour are problematic for many managers.

Table D.1 Issues of concern in doing business in the Netherlands

\begin{tabular}{|c|c|c|c|c|}
\hline Issue & $\mathrm{N}$ & Rank & Mean & S.d. \\
\hline \multicolumn{5}{|l|}{ Labour related } \\
\hline Social security costs & 86 & 3 & 3.36 & 1.00 \\
\hline Availability of technical skills & 86 & 2 & 3.38 & 1.20 \\
\hline Price of technical labour & 86 & 7 & 3.22 & 1.14 \\
\hline Availability of management skills & 86 & 6 & 3.24 & 1.18 \\
\hline Price of managerial labour & 86 & 11 & 2.92 & 1.17 \\
\hline Availability of commercial skills & 86 & 4 & 3.34 & 1.25 \\
\hline Price of commercial labourers & 86 & 12 & 2.92 & 1.18 \\
\hline Availability of unskilled labour & 86 & 33 & 2.05 & 1.21 \\
\hline Price of unskilled labour & 86 & 34 & 2.05 & 1.21 \\
\hline \multicolumn{5}{|l|}{ Transportation and infrastructure related } \\
\hline Traffic congestion & 86 & 1 & 3.84 & 1.15 \\
\hline Local road infrastructure & 86 & 8 & 3.21 & 1.19 \\
\hline Freight transportation system & 86 & 19 & 2.66 & 1.25 \\
\hline Public transportation system & 86 & 28 & 2.43 & 1.11 \\
\hline ICT availability & 86 & 13 & 2.88 & 1.31 \\
\hline Transportation costs & 85 & 10 & 3.01 & 1.30 \\
\hline Availability of office space & 86 & 15 & 2.85 & 1.10 \\
\hline Availability of warehousing space & 86 & 23 & 2.53 & 1.31 \\
\hline \multicolumn{5}{|l|}{ Legislation related } \\
\hline Dutch labour laws & 86 & 9 & 3.02 & 1.19 \\
\hline European business practice & 86 & 17 & 2.76 & 1.04 \\
\hline Environmental regulations & 86 & 16 & 2.84 & 1.17 \\
\hline Investment legislation & 86 & 25 & 2.51 & 1.01 \\
\hline \multicolumn{5}{|l|}{ Tax-system related } \\
\hline Corporate tax system & 86 & 14 & 2.87 & 1.17 \\
\hline Personal tax system & 86 & 5 & 3.31 & 1.14 \\
\hline VAT system & 86 & 20 & 2.63 & 1.07 \\
\hline Import duties & 86 & 30 & 2.40 & 1.13 \\
\hline Restrictions on the repatriation of profits & 86 & 24 & 2.52 & 1.10 \\
\hline \multicolumn{5}{|l|}{ Other } \\
\hline Exchange rates & 86 & 21 & 2.58 & 1.22 \\
\hline Dutch banking and finance & 86 & 29 & 2.42 & 1.10 \\
\hline Personal and family adjustment problems & 86 & 31 & 2.34 & 1.05 \\
\hline Employee housing & 86 & 22 & 2.57 & 1.19 \\
\hline European protectionism & 86 & 27 & 2.44 & 1.22 \\
\hline Small size of the Dutch market & 86 & 18 & 2.72 & 1.22 \\
\hline Lack of suitable local business partners & 86 & 32 & 2.27 & 1.06 \\
\hline Differences in Business attitudes & 86 & 26 & 2.47 & 1.11 \\
\hline
\end{tabular}


The managers in our sample are not hindered by import duties (2.40) or fear of European protectionism (2.44), nor are they concerned about the Dutch financial system (2.42) or the (small) size of the Dutch market (2.72). Furthermore, suitable business partners are no restriction on foreign affiliates' Dutch activities (2.27). Both the availability (2.05) and price (2.05) of unskilled labour are no problem for the average foreign manager.

Considering the 'average' manager conceals problems that may concern particular groups of foreign firms. As we can see in Tables D.2 and D.3, we again find strong differences in problems when we distinguish groups of affiliates according to their characteristics, like we did in Chapter five. Both tables only list those variables for which such significant differences do exist.

From Table D.2 we can conclude that affiliates whose parents are located outside the European Union in general experience bigger problems while doing business in the Netherlands than affiliates from inside the EU do. On average, these affiliates put a much stronger emphasis on the negative influence of the personal tax system (3.64) and Dutch labour laws (3.43) than EU-firms do. Furthermore the availability of technical (3.50) and management skills (3.48) is also considered a bigger problem by affiliates with a non-EU parent. ICT availability wasn't problematic for the entire sample (2.88) but for non-EU firms it is more so (3.23). Not surprisingly, exchange rates are a considerable issue of concern for firms outside the EU. Within the EU, the currencies have been under the snake agreement, limiting their flexibility and resulting in fewer risks.

Table D.2 Differences in problems depending on home country of affiliate

\begin{tabular}{|c|c|c|c|}
\hline Deterrent & Mean EU & Mean other & $\begin{array}{r}\text { Significance } \\
\text { (2-tailed) }\end{array}$ \\
\hline Availability of technical skills & 3.12 & 3.50 & 0.045 \\
\hline Availability of management skills & 3.00 & 3.48 & 0.060 \\
\hline Freight transportation system & 2.38 & 2.93 & 0.041 \\
\hline Public transportation system & 2.21 & 2.64 & 0.078 \\
\hline ICT availability & 2.52 & 3.23 & 0.012 \\
\hline Dutch labour laws & 2.60 & 3.43 & 0.001 \\
\hline European business practice & 2.40 & 3.09 & 0.002 \\
\hline Investment legislation & 2.17 & 2.84 & 0.002 \\
\hline Corporate tax system & 2.64 & 3.09 & 0.075 \\
\hline Personal tax system & 2.98 & 3.64 & 0.007 \\
\hline VAT system & 2.40 & 2.84 & 0.059 \\
\hline Import duties ${ }^{*}$ & 2.05 & 2.73 & 0.005 \\
\hline Restrictions on profit repatriation & 2.26 & 2.77 & 0.031 \\
\hline Exchange rates & 2.10 & 3.05 & 0.000 \\
\hline Dutch banking and finance & 2.12 & 2.70 & 0.013 \\
\hline Personal and family adjustment problems & 2.10 & 2.57 & 0.036 \\
\hline European protectionism & 2.02 & 2.84 & 0.002 \\
\hline
\end{tabular}

'Levene's test for equality of variances shows that for import restrictions we cannot assume equal variances. We took this into consideration with the t-test for equality of means 
We also see considerable differences in issues of concern between firms when considering their sales focus. The affiliates that focus their sales in the Netherlands generally put less emphasis on the potential problems than those focussing their sales to more markets (Table D.3). The later group has significantly larger problems with the availability and the price of qualified technical and managerial labour. They also put stronger emphasis on the corporate and personal tax system as deterrents to doing business in the Netherlands. The group of affiliates with a mixed sales focus (servicing both the Netherlands and other markets) indicates problems with commercial labour (availability 3.78 , price 3.35 ) as well.

Table D.3 Differences in problems depending on the sales focus of the affiliate

\begin{tabular}{|l|c|c|c|c|}
\hline Deterrent & $\begin{array}{c}\text { Mean } \\
\text { NL } \\
(>0.90)\end{array}$ & $\begin{array}{c}\text { Mean } \\
\text { Mixed } \\
(0.10-0.90)\end{array}$ & $\begin{array}{c}\text { Mean } \\
\text { exports } \\
(<0.10)\end{array}$ & $\begin{array}{c}\text { Significance } \\
\text { (2-tailed) }\end{array}$ \\
\hline Social security costs & $3.09^{\circ}$ & $3.70^{\circ}$ & 3.61 & 0.032 \\
Availability of technical skills & $2.91^{* \prime \prime}$ & $3.87^{\circ}$ & $3.83^{\prime \prime}$ & 0.001 \\
Price of technical labour & $2.86^{* \prime}$ & $3.57^{\circ}$ & $3.61^{\prime \prime}$ & 0.013 \\
Availability of management skills & $2.91^{\circ}$ & $3.61^{\circ}$ & 3.56 & 0.029 \\
Price of managerial labour & $2.64^{\prime \prime}$ & 3.04 & $3.33^{\prime \prime}$ & 0.074 \\
Availability of commercial labour & $3.09^{\circ}$ & $3.78^{\circ}$ & 3.33 & 0.101 \\
Price of commercial labour & 2.75 & 3.35 & 2.72 & 0.109 \\
Investment legislation & $2.27^{\prime \prime}$ & 2.57 & $2.89^{\prime \prime}$ & 0.071 \\
Corporate tax system & $2.66^{\prime \prime}$ & 2.83 & $3.39^{\prime \prime}$ & 0.080 \\
Personal tax system & $2.91^{\circ \prime}$ & $3.61^{\circ}$ & $3.89^{\prime \prime}$ & 0.002 \\
Small size of the Dutch market & $2.86^{\prime \prime}$ & 3.04 & $1.94^{\prime \prime}$ & 0.008 \\
\hline
\end{tabular}

- significant difference between mean 1 and mean 2 at the 0.05 level

" significant difference between mean 1 and mean 3 at the 0.05 level

$>$ significant difference between mean 2 and mean 3 at the 0.05 level

\section{D.4 Factor analysis}

Table D.4 gives an overview of the results of the factor analysis conducted on the questionnaire data. Factor analysis was performed on the 34 explanatory variables with the primary goal of data reduction. The null hypothesis that the population correlation matrix is an identity matrix is rejected by Bartlett's test of sphericity (appr. Chi-Square = 2209.3, df $=561$, significant at the 0.0001 level). Furthermore, the Kaiser-Meyer-Olkin measure of sampling adequacy is 0.827 . We can therefore conclude that factor analysis is appropriate for this sample.

The principal component method, using varimax rotation, reduced the explanatory variables to eight factors having eigenvalues greater than 1.0. For the purpose of interpretation, each factor was composed of variables loading 0.4 or higher on that factor. In 8 instances, where variables loaded 0.4 or above on more than one factor, each variable was assigned to the factor where it had the highest loading. We have made one 
adjustment on the factors for interpretability. Environmental legislation loaded on factors three $(0.458)$ and four $(0.378)$. We have chosen to group environmental legislation with other governmental regulations (in factor 4 ).

In total, 74.2 percent of total variance was explained by these 8 factors. Table D. 4 gives an overview of the extracted factors in the order in which they were extracted. The eight factors may be summarised as ease of trading, business environment, labour-related costs, taxes and legislation, availability of skilled labour, unskilled labour, real estate availability, and ease of road transportation. The calculated Cronbach's alpha values are acceptably high (ranging between 0.71 and 0.93 ).

\section{D.5 Discussion}

From the analyses it is clear that one of the most important problems is the traffic congestion on Dutch roads. This result is not surprising considering that 47 (55 percent) of the firms participating in the study indicate that logistics is an important or very important activity at their Dutch establishment. As the Netherlands is among the most densely populated areas in the world, roads are crowded, particularly in the Randstad area. This is a nuisance for both foreign and indigenous firms. Related to this problem are concerns about the local road infrastructure and the transportation costs. When transportation has to be scheduled at times when traffic is less busy, of course drivers need to be compensated for those irregular hours. For firms that use the Netherlands as an export hub for all of Europe, this can result in a considerable cost increase at the expense of profits.

The Dutch ministry of traffic is making serious attempts at solving these problems through the Bereikbaarheidsoffensief Randstad (accessibility offensive Randstad). Expansions of the infrastructure facilities (both highways and investments in public transportation) are combined with measures involving payment for actual use, particularly during rush-hours. However, although a lot is being done to solve these problems, our results again stress the importance of dealing with this problem quickly. Given that the Netherlands tries to be a 'gateway to Europe' these problems need to be solved to remain competitive and attractive for foreign establishments.

The second group of important problems that stands out is the availability of skilled technical, commercial, and managerial labour. In case of technical labour, many managers furthermore indicate that the cost of skilled labourers is becoming a problem. Given that few skilled employees are available, their price naturally increases. Just as with transportation costs, high wages can be a serious burden on the profitability of the firm. The tight labour market for skilled employees is an acknowledged problem. It is particularly burdensome in high tech industries (such as the one analysed) that need qualified labourers to produce and sell their products. It is generally believed that a lack of available employees acts as a deterrent for new establishments (Ilmakunnas and Topi 1999). 
Table D.4 Factors showing the issues of concern of foreign entrepreneurs in the Netherlands

\begin{tabular}{|c|c|c|c|c|c|c|c|}
\hline Factors & $\begin{array}{l}\text { Factor } \\
\text { loads }\end{array}$ & $\begin{array}{l}\text { Eigen- } \\
\text { value }\end{array}$ & $\begin{array}{l}\% \text { of } \\
\text { variance } \\
\text { explained }\end{array}$ & $\begin{array}{l}\text { Cum. } \\
\%\end{array}$ & $\begin{array}{l}\text { Cron- } \\
\text { bach } \\
\text { alpha }\end{array}$ & $\begin{array}{l}\text { Item- } \\
\text { to-total } \\
\text { corre- } \\
\text { lations }\end{array}$ & $\mathrm{N}$ \\
\hline Factor 1: Ease of trading & & 5.468 & 16.1 & 16.1 & 0.93 & & 85 \\
\hline Transportation costs & 0.795 & & & & & 0.6681 & \\
\hline Freight transportation system & 0.739 & & & & & 0.7332 & \\
\hline Exchange rates & 0.668 & & & & & 0.7592 & \\
\hline ICT availability & 0.665 & & & & & 0.6487 & \\
\hline Import duties & 0.642 & & & & & 0.6951 & \\
\hline Restrictions on the repatriation of profits & 0.631 & & & & & 0.7229 & \\
\hline Dutch banking and finance & 0.596 & & & & & 0.6872 & \\
\hline Public transportation system & 0.573 & & & & & 0.6180 & \\
\hline Value-added tax system & 0.521 & & & & & 0.7684 & \\
\hline European business practice & 0.507 & & & & & 0.7369 & \\
\hline Investment legislation & 0.407 & & & & & 0.6724 & \\
\hline Factor 2: Business environment & & 3.924 & 11.5 & 27.6 & 0.83 & & 86 \\
\hline Lack of suitable business partners & 0.845 & & & & & 0.7625 & \\
\hline Small size of Dutch market & 0.705 & & & & & 0.5032 & \\
\hline Personal and family adjustment problems & 0.619 & & & & & 0.6621 & \\
\hline European protectionism & 0.607 & & & & & 0.6659 & \\
\hline Differences in business attitudes & 0.549 & & & & & 0.5477 & \\
\hline Factor 3: Labour-related costs & & 3.590 & 10.6 & 38.2 & 0.85 & & 86 \\
\hline Price of technical labour & 0.796 & & & & & 0.7523 & \\
\hline Social security costs & 0.715 & & & & & 0.6254 & \\
\hline Price of managerial labour & 0.672 & & & & & 0.7186 & \\
\hline Employee housing & 0.507 & & & & & 0.5249 & \\
\hline Price of commercial labour & 0.479 & & & & & 0.6689 & \\
\hline Factor 4: Taxes and legislation & & 3.336 & 9.8 & 48.0 & 0.81 & & 86 \\
\hline Corporate tax system & 0.801 & & & & & 0.7167 & \\
\hline Dutch labour laws & 0.717 & & & & & 0.6385 & \\
\hline Personal tax system & 0.680 & & & & & 0.6756 & \\
\hline Environmental regulations & 0.378 & & & & & 0.4961 & \\
\hline Factor 5: skilled labour & & 3.145 & 9.2 & 57.2 & 0.85 & & 86 \\
\hline Availability of technical skills & 0.794 & & & & & 0.6790 & \\
\hline Availability of commercial skills & 0.784 & & & & & 0.7192 & \\
\hline Availability of managerial skills & 0.695 & & & & & 0.7442 & \\
\hline Factor 6: Unskilled labour & & 2.385 & 7.0 & 64.2 & 0.92 & & 86 \\
\hline Availability of unskilled labour & 0.927 & & & & & 0.8546 & \\
\hline Price of unskilled labour & 0.891 & & & & & 0.8546 & \\
\hline Factor 7: Real estate & & 1.730 & 5.1 & 69.3 & 0.75 & & 86 \\
\hline Availability of office space & 0.742 & & & & & 0.6124 & \\
\hline Availability of warehousing space & 0.658 & & & & & 0.6124 & \\
\hline Factor 8: Road transportation & & 1.667 & 4.9 & 74.2 & 0.71 & & 86 \\
\hline Traffic congestion & 0.792 & & & & & 0.5516 & \\
\hline Local road infrastructure & 0.735 & & & & & 0.5516 & \\
\hline
\end{tabular}

The strong emphasis on the availability of commercial skills can be explained by the huge share of firms in the sample that emphasise sales as their main activity. Given that 
only 16 firms actually manufacture products at their Dutch location while 81 indicate that sales are a (very) important activity at their current site, there is an enormous demand for skilled commercial workers to sell products in both the Dutch and the European market. Particularly the group of affiliates with a mixed sales focus (servicing both the Netherlands and other markets) indicates problems with commercial labour. Servicing many markets is very demanding on the knowledge and quality of the employees. For most of the sales outside the Netherlands, commercial labour needs to be multi-lingual. However, this does not appear to be a problem. As indicated in Chapter five, the multilingual workforce in the Netherlands is actually one of the main attractions.

From the results of the questionnaire, we can conclude that affiliates whose parents are located outside the European Union in general experience bigger problems while doing business in the Netherlands than affiliates from inside the EU do. It is likely that these problems are associated with unfamiliarity with the Dutch market and Dutch business rules. On average, affiliates from outside the EU put a much stronger emphasis on the negative influence of the personal tax system and Dutch labour laws than EU-firms do. This result is not surprising considering the relative similarity in those systems among European countries. However, considerable differences exist for instance between the US and the Netherlands when it comes to firing employees. The cumbersome procedures in the Netherlands can be seen as an obstacle in doing business.

\section{D.6 Conclusion}

Overall, the Netherlands appears to be an attractive location for establishments by foreign firms. However, the historical success in attracting FDI should not be taken for granted. Monitoring and handling the problems in doing business in the Netherlands is a necessary condition for continued inflows of FDI. The largest concerns are with the availability of skilled labour and ease of road transportation/ traffic congestion. Priority should be given to solving these problems if the Netherlands wants to remain an attractive location for foreign establishment. Of course, relocating an establishment is expensive and cumbersome and therefore not very likely in the near future. However, both factors hinder the expansion of firms as well, which in the short run may be a much larger problem. Although most foreign firms have indicated expansion plans in the Dutch market, their difficulties in getting qualified personnel may limit their possibilities. 


\section{REFERENCES}

A

Acs, Z. J., and Audretsch, D. B. (1989). Small-Firm Entry in U.S. Manufacturing. Economica, 56 (222), 255-265.

Agarwal, J. (1980). Determinants of Foreign Direct Investment: A Survey. Weltwirtschaftliches Archiv, $116(4), 739-773$.

Agarwal, S., and Ramaswami, S. (1992). Choice of Foreign Entry Mode: Impact of Ownership, Location and Internationalisation Factors. Journal of International Business Studies, 23 (1), 1-27.

Ajami, R. A., and BarNiv, R. (1984). Utilizing Economic Indicators in Explaining Foreign Direct Investment in the U.S. Management International Review, 24 (4), 16-26.

Alebeek, H. van, Wassenaar, A. van, and Lewis, B. (1997). Boosting Dutch Economic Performance. The McKinsey Quarterly (4), 154-169.

Aliber, R. (1970). A Theory of Foreign Direct Investment. In C. P. Kindleberger (Ed.), The International Corporation. Cambridge: MIT Press.

Allen, S. D., Bray, J., and Seaks, T. G. (1997). A Multinomial Logit Analysis of the Influence of Policy Variables and Board Experience of FOMC Voting Behavior. Public Choice, 92, 27-39.

Andersson, T., Fredriksson, T., and Svensson, R. (1996). Multinational Restructuring, Internationalization and Small Economies. The Swedish Case. London: Routledge.

Aristotelous, K., and Fountas, S. (1996). An Empirical Analysis of Inward Foreign Direct Investment Flows in the EU with Emphasis on the Market Enlargement Hypothesis. Journal of Common Market Studies, 34 (4), 571-583.

Armstrong, H. W., and Read, R. (1998). Trade and Growth in Small States: The Impact of Global Trade Liberalisation. World Economy, 21 (4), 563-585.

Arora, A., and Fosfuri, A. (2000). Wholly Owned Subsidiary Versus Technology Licensing in the Worldwide Chemical Industry. Journal of International Business Studies, 31 (4), 555-572.

Audretsch, D. B. (1991). New Firm Survival and the Technological Regime. Review of Economics and Statistics, 73 (3), 441-450.

Audretsch, D. B. (1994). Business Survival and the Decision to Exit. Journal of the Economics of Business, 1 (1), 125-137.

Ayal, I., and Izraeli, D. (1997). International Market Expansion of High-Technology Firms. In H. VernonWortzel and L. H. Wortzel (Eds.), Strategic Management in a Global Economy (3rd ed., pp. $102-$ 109). New York: John Wiley and Sons.

\section{B}

Backstrom, C. H., and Hursh-César, G. (1981). Survey Research. (2nd ed.). New York: MacMillan Publishing Co.

Bajo-Rubio, O., and Sosvilla-Rivero, S. (1994). An Econometric Analysis of Foreign Direct Investment in Spain: 1964-1989. Southern Economic Journal, 61 (1), 104-120.

Barkema, H., Bell, J., and Pfennings, J. M. (1996). Foreign Entry, Cultural Barriers and Learning. Strategic Management Journal, 17 (2), 151-166.

Barrell, R., and Pain, N. (1999). Domestic Institutions, Agglomerations and Foreign Direct Investment in Europe. European Economic Review, 43 (4-6), 925-934.

Bartik, T. J. (1985). Business Location Decisions in the United States: Estimates of the Effects of Unionization, Taxes, and Other Characteristics of States. Journal of Business and Economic Statistics, 3 (1), 14-22. 
Bartlett, C. A., and Ghoshal, S. (1986). Tap Your Subsidiaries for Global Reach. Harvard Business Review, 64 (6), 87-94.

Bartlett, C. A., and Ghoshal, S. (1987). Managing Across Borders: New Strategic Requirements. Sloan Management Review, 28 (Summer), 7-17.

Bartlett, C.A., and Ghoshal, S. (1989). Managing Across Borders - The Transnational Solution. Boston: Harvard Business School Press.

Beers, C. P. van, Braber, M. C., Hoen, A. R., Moor, A. P. G. de, and Poppelaars, J. A. A. (1999). De gevolgen voor Nederland van directe buitenlandse investeringen (Onderzoeksreeks 96). Den Haag: IOObv.

Behrmann, J. N. (1972). The Role of International Companies in Latin America: Autos and Petrochemicals. Lexington MA: Lexington Books.

Beije, P., and Nuys, O. (1997). How Institutional is the Diamond? A Critical Analysis of Porter with Regard to Small Countries. Erasmus University Management Report (51).

Belderbos, R. (1999). Dutch Multinationals in Japan. In R. van Hoesel and R. Narula (Eds.), Multinational Enterprises from the Netherlands (pp. 241-281). London: Routledge.

Bell, J. H. J. (1996). Joint or Single Venturing? An Eclectic Approach to Foreign Entry Mode Choice. Helmond: WIBO dissertatiedrukkerij.

Benito, G. R. G. (1997). Divestment of Foreign Production Operations. Applied Economics, 29 (10), 1365-1377.

Benito, G. R. G., Larimo, J., Narula, R., and Pedersen, T. (2000, November). Multinational Enterprises from Small Economies: The Internationalisation Patterns of Large Companies from the Nordic Countries. Paper presented at the Academy of International Business Annual Meeting, Phoenix, Arizona.

Benito, G. R. G., Grøgaard, B., and Narula, R. (2001, May) The Effect of Regional Integration on Subsidiary Roles: The Heterogeneity of Subsidiaries in the Nordic Countries, Paper presented at the Nordic Workshop in International Business, Idöborg, Sweden.

Bennett, R. (1997). European Business. London: Pitman Publishing.

Billington, N. (1999). The Location of Foreign Direct Investment: An Empirical Analysis. Applied Economics, 31 (1), 65-76.

Birkinshaw, J., and Fry, N. (1998). Subsidiary Initiatives to Develop New Markets. Sloan Management Review, 39 (3), 51-61.

Birkinshaw, J., and Hood, N. (1998). Multinational Subsidiary Evolution: Capability and Charter Change in Foreign-Owned Subsidiary Companies. Academy of Management Review, 23 (4), 773-795.

Birkinshaw, J., and Hood, N. (2000). Characteristics of Foreign Subsidiaries in Industry Clusters. Journal of International Business Studies, 31 (1), 141-154.

Birkinshaw, J. M., and Morrison, A. J. (1995). Configurations of Strategy and Structure in Subsidiaries of Multinational Corporations. Journal of International Business Studies, 26 (4), 729-753.

Boddewyn, J. J. (1983). Foreign and Domestic Divestment and Investment Decisions: Like or Unlike. Journal of International Business Studies, 14 (Winter), 23-35.

Boeckhout, I. J., Verhoeff, B. M., and Verster, A. C. P. (1987). De Randstad als vestigingsplaats voor internationaal georiënteerde bedrijvigheid. Economisch-Statistische Berichten (2-12), 1138-1145.

Bolkestein, F. (1999). The Dutch Model: The High Road that Leads out of the Small Countries. The Economist, 351 (May 22) (8120), 75-76.

Braunerhjelm, P., and Svensson, R. (1996). Host Country Characteristics and Agglomeration in Foreign Direct Investment. Applied Economics, 28 (7), 833-840. 
Brouthers, K. D., and Brouthers, L. E. (1997). Explaining National Competitive Advantage for a Small European Country: A Test of Three Competing Models. International Business Review, 6 (1), 5370.

Brouthers, K. D., and Brouthers, L. E. (2001). Explaining the National Cultural Distance Paradox. Journal of International Business Studies, 32 (1), 177-189.

Brouthers, L. E., Brouthers, K. D., and Werner, S. (1996). Dunning's Eclectic Theory and the Smaller Firm: The Impact of Ownership and Locational Advantages on the Choice of Entry Mode in the Computer Software Industry. International Business Review, 5 (4), 377-394.

Brouthers, L. E., Brouthers, K. D., and Werner, S. (1999). Is Dunning's Eclectic Framework Descriptive or Normative? Journal of International Business Studies, 30 (4), 831-844.

Buck, R. (1989). Nederland, de Randstad en buitenlandse investeerders. Inleiding op congres "de Randstad in Europees perspectief". Nijmegen: Buck Consultants International.

Buckley, P. J., and Casson, M. (1976). The Future of the Multinational Enterprise. London: MacMillan Press.

Buckley, P. J., and Dunning, J. H. (1976). The Industrial Structure of US Direct Investment in the UK. Journal of International Business Studies, 7 (2), 5-13.

C

Cadot, O., and Desruelle, D. (1998). R\&D: Who Does the R, Who Does the D? Journal of International Economics, 46 (1), 87-103.

Calliano, R., and Carpano, C. (2000). National Systems of Technological Innovation, FDI, and Economic Growth: The Case of Ireland. Multinational Business Review, 8 (2), 16-25.

Carlton, D. W. (1983). The Location and Employment Choices of New Firms: An Econometric Model with Discrete and Continuous Endogenous Variables. The Review of Economics and Statistics, 65 (3), 440-449.

Carr, E. (1996). Survey of Business in Europe (1): A Fortress against Change. The Economist, 341 (23 Nov.) (7993), 3.

Casella, A. (1995). Large Countries, Small Countries and the Enlargement of Trade Blocks. NBER Working Paper Series (5365).

Caves, R. E. (1971). International Corporations: The Industrial Economics of Foreign Investment. Economica (new series), XXXVIII (February), 1-27.

Caves, R. E. (1996). Multinational Enterprises and Economic Analysis. (2nd ed.). Cambridge: Cambridge University Press.

CBIN (1996). Jaarbeeld 1996. The Hague: Commissariaat voor Buitenlandse Investeringen in Nederland.

CBIN (1997). The Netherlands. A First Class Location for International Activities. The Hague: Commissariaat voor Buitenlandse Investeringen in Nederland.

CBS (1981, 1992). Statistisch Zakboek 1981. 's-Gravenhage: Staatsuitgeverij.

CBS (1997) Bedrijven in Nederland. Voorburg/Heerlen: Centraal Bureau voor de Statistiek.

CBS (2001a). Economie groeit in 2000 met 3.9\%. Voorburg: Centraal Bureau voor de Statistiek.

CBS (2001b). Statistisch jaarboek 2001. Voorburg/Heerlen: Centraal Bureau voor de Statistiek.

Chandprapalert, A. (2000). The Determinants of U.S. Direct Investment in Thailand: A Survey on Managerial Perspectives. Multinational Business Review, 8 (2), 82-88.

Chen, E. (1983). Multinationals from Hong Kong. In S. Lall (Ed.), The New Multinationals (pp. 88-136). Chichester: John Wiley.

Cheng, L. K., and Kwan, Y. K. (2000). What are the Determinants of the Location of Foreign Direct Investment? The Chinese Experience. Journal of International Economics, 51 (2), 379-400. 
Contractor, F. J. (1984). Choosing between Direct Investment and Licensing: Theoretical Considerations and Empirical Tests. Journal of International Business Studies, 15 (3), 167-188.

CPB (2001a). Macro Economische Verkenningen, Den Haag: Sdu Uitgevers.

CPB (2001b). Nieuwe Raming 2001/2002, http://www.cpb.nl/nl/pub/ notitie/ 01nov 2001/ notitie. pdf [retrieved 8/5/2002].

CPB (2002a). Press release 21: CPB Report 2002/1, www.cpb.nl/nl/news/2002_21.html [retrieved 08/05/2002].

CPB (2002b). CPB Report 2002/1, Den Haag: Sdu Uitgevers.

Cryer, J. D., and Miller, R. B. (1994). Statistics for Business. Data Analysis and Modelling. (2nd ed.). Belmont, California: International Thomson Publishing.

Culem, C. (1988). The Locational Determinants of Direct Foreign Investment among Industrialized Countries. European Economic Review, 32, 885-904.

\section{D}

Davidson, W. H., and McFetridge, D. G. (1985). Key Characteristics in the Choice of International Technology Transfer. Journal of International Business Studies, 16 (summer), 5-21.

Day, G.S., and Nedungadi, P. (1994) Managerial Representations of Competitive Advantage. Journal of Marketing, 58 (April), 31-44.

Dicken, P. (1992). Global Shift. The Internationalization of Economic Activity. (2nd ed.). London: Guilford Press.

Dicken, P. (1998). Global Shift. Transforming the World Economy. (3rd ed.). New York/London: Guilford Press.

Diederen, B. (2000). De invloed van grote buitenlandse ondernemingen op de Nederlandse economie. CBS Industriemonitor (October), http://www.cbs.nl/nl/producten/artikelen/ bedrijfsleven/industrie/im-10-00.pdf.

Dillen, J. G. van (1970). Van Rijkdom en Regenten. Handboek tot de economische en sociale geschiedenis van Nederland tijdens de Republiek. 's Gravenhage: Martinus Nijhoff.

Dillon, W. R., Madden, T. J., and Firtle, N. H. (1990). Marketing Research in a Marketing Environment. (2nd ed.). Homewood, Illinois: Irwin.

DNB (2000a). Bijzondere financiële instellingen in Nederland. Statistisch Bulletin (maart), 19-28.

DNB (2000b). Directe Investeringen in het buitenland (standen), [internet]. De Nederlandsche Bank. Available: www.dnb.nl [2000, 14/2/2001].

DNB (2001). Nederland wereldwijd sterk investeringsland. Statistisch Bulletin, (maart), 11-16.

DNB (2002). Nederland in het Eurogebied. Kwartaalbericht Maart 2002, 7-15.

Druce, C. (2002). Engineers in Obsolete Component Nightmare, Electronics Weekly, $2041,1$.

Dunning, J. H. (1980). Towards an Eclectic Theory of International Production: Some Empirical Tests. Journal of International Business Studies, 11 (1), 9-31.

Dunning, J. H. (1981). International Production and the Multinational Enterprise. London, Boston: Allen and Unwin.

Dunning, J. H. (1988a). The Eclectic Paradigm of International Production: A Restatement and Some Possible Extensions. Journal of International Business Studies, 19, 1-31.

Dunning, J. H. (1988b). Explaining International Production. London, Boston: Unwin Hyman.

Dunning, J. H. (1992). Transaltantic Foreign Direct Investment and European Integration: The Record Assessed. International Economic Journal, 6 (1), 59-81.

Dunning, J. H. (1993). Multinational Enterprises and the Global Economy. Wokingham: AddisonWesley. 
Dunning, J. H. (1994). Re-evaluating the Benefits of Foreign Direct Investment. Transnational Corporations, 3 (1), 23-51.

Dunning, J. H. (1995). Reappraising the Eclectic Paradigm in the Age of Alliance Capitalism. Journal of International Business Studies, 26, 461-491.

Dunning, J.H. (1997a). The European Internal Market Programme and Inbound Foreign Direct Investment. Journal of Common Market Studies. 35 (1) 1-30.

Dunning, J.H. (1997b). The European Internal Market Programme and Inbound Foreign Direct Investment. Journal of Common Market Studies. 35 (2) 189-223.

Dunning, J. H. (1998). Resolving Some Paradoxes of the Emerging Global Economy: Small Nations as Trailblazers. Reading and Rutgers Universities.

Dunning, J. H. (2000). The Eclectic Paradigm as an Envelope for Economic and Business Theories of MNE Activity. International Business Review, 9 (2), 163-190.

Dunning, J. H. (2001). The Eclectic (OLI) Paradigm of International Production: Past, Present and Future. International Journal of the Economics of Business, 8 (2), 173-190.

Dunning, J. H., and Kundu, S. K. (1995). The Internationalization of the Hotel Industry - Some New Findings from a Field Study. Management International Review, 35 (2), 101-133.

$\mathbf{E}$

Edquist, C., and Lundvall, B.-A. (1993). Comparing the Danish and Swedish Systems of Innovation. In

R. R. Nelson (Ed.), National Innovation Systems - A Comparative Analysis (pp. 265-298).

Oxford: Oxford University Press.

Ernst and Young (1996). Doing Business in the Netherlands. Rotterdam: Ernst and Young.

Erramilli, M. K., and Roa, C. P. (1993). Service Firms' International Entry Mode Choice: A Modified Transaction Cost Analysis Approach. Journal of Marketing, 57 (July), 19-38.

European Electronics Market Forecast (2001). European Electronics Industry - Q3 Update, http://www.rer.co.uk/pdf/EEMF\%20SEPT\%202001.pdf, retrieved May 6th, 2002.

F

Ferris, S. P., Thompson, G. R., and Valsan, C. (1994). Foreign Direct Investment in an Emerging Market Economy. Eastern European Economics (July-August), 81-95.

Forsgren, M., Holm, U., and Johanson, J. (1995). Division Headquarters go Abroad - A Step in the Internationalization of the Multinational Corporation. Journal of Management Studies, 32 (4), 475-491.

Forsgren, M., Pedersen, T., and Foss, N. J. (1999). Accounting for the Strength of MNC Subsidiaries: the Case of Foreign-owned Firms in Denmark. International Business Review, 8 (2), 181-196.

Fraser, J., and Oppenheim, J. (1997). What's New about Globalisation. The McKinsey Quarterly (2), 168179.

Friedman, J., Gerlowski, D. A., and Silberman, J. (1992). What Attracts Foreign Multinational Corporations? Evidence from Branch Plant Location in the United States. Journal of Regional Science, 32 (4), 403-418.

Froot, K., and Stein, J. (1991). Exchange Rates and Foreign Direct Investment: An Imperfect Capital Market Approach. Quarterly Journal of Economics, 106 (4), 1191-1217.

G

Gatignon, H., and Anderson, E. (1988). The Multinational Corporation's Degree of Control over Foreign Subsidiaries: An Empirical Test of a Transaction Cost Explanation. Journal of Law, Economics and Organization, 4 (2), 305-336. 
Gomes-Casseres, B. (1989). Ownership Structures of Foreign Subsidiaries: Theory and Evidence. Journal of Economic Behavior and Organization, 11 (1), 1-25.

Gomes-Casseres, B. (1990). Firm Ownership Preferences and Host Government Restrictions. An Integrated Approach. Journal of International Business Studies, 21 (1), 1-22.

Govindarajan, V., and Gupta, A. (2000). Analysis of the Emerging Global Arena. European Management Journal, 18 (3), 274-284.

Green, P. E., Tull, D. S., and Albaum, G. (1988). Research for Marketing Decisions. (5th ed.). Englewood Cliffs, New Jersey: Prentice-Hall, Inc.

Greene, W. H. (2000). Econometric Analysis. (4th ed.). Upper Saddle River, NJ: Prentice Hall.

Griffin, R. W., and Pustay, M. W. (1999). International Business. A Managerial Perspective. (2nd ed.). Reading, Massachusetts: Addison-Wesley.

Grosse, R., and Trevino, L. (1996). Foreign Direct Investment in the United States: An Analysis of Country of Origin. Journal of International Business Studies, 27 (1), 139-155.

Guisinger, S. (2001). From OLI to OLMA: Incorporating Higher Levels of Environmental and Structural Complexity into the Eclectic Paradigm. International Journal of the Economics of Business, 8 (2), 257-72.

Gutierrez, M. A. (1996). Is Small "Beautiful" for Economic Integration? The Americas. Jounal of World Trade, 30 (4), 173-215.

\section{$\mathbf{H}$}

Hadjimanolis, A., and Dickson, K. (2001). Development of National Innovation Policy in Small Developing Countries: The Case of Cyprus. Research Policy, 30 (5), 805-817.

Hagedoorn, J., and Narula, R. (1996). Choosing Modes of Governance for Strategic Technology Partnering: International and Sectoral Differences. Journal of International Business Studies, 27 (2), 265-284.

Hair Jr., J. F., Anderson, R. E., Tatham, R. L., and Black, W. C. (1998). Multivariate Data Analysis. (5th ed.). Upper Saddle River: Prentice Hall.

Hall, B. H. (1987). The Relationship between Firm Size and Firm Growth in the U.S. Manufacturing Sector. Journal of Industrial Economics, 35 (4), 583-605.

Hamilton, R. T., and Chow, Y. K. (1993). Why Managers Divest: Evidence from New Zealand's Largest Companies. Strategic Management Journal, 14 (6), 479-84.

Harzing, A.-W. (2000). An Empirical Analysis and Extension of the Bartlett and Ghoshal Typology of Multinational Companies. Journal of International Business Studies, 31 (1), 101-120.

Head, K., Ries, J., and Swenson, D. (1995). Agglomeration Benefits and Location Choice: Evidence from Japanese Manufacturing Investments in the United States. Journal of International Economics, 38 (3-4), 223-247.

Hennart, J. F. (1982). A Theory of Multinational Enterprise. Ann Arbor: University of Michigan Press.

Hennart, J. F. (1989). Can the New Forms of Investment Substitute for the Old Forms: A Transaction Costs Perspective. Journal of International Business Studies, XX, 211-233.

Hoesel, R. van (1997). Beyond Export-led Growth: The Emergence of New Multinational Enterprises from Korea and Taiwan. Amsterdam: Thesis Publishers.

Hoesel, R. van, and Narula, R. (1999). Multinational Enterprises from the Netherlands. London: Routledge.

Hofstede, G. H. (1980). Cultures Consequence: International Differences in Work-Related Values. Beverly Hills CA: Sage.

Hofstede, G. H. (1997). Cultures and Organizations, Software of the Mind. (3rd ed.). New York: McGraw-Hill. 
Hogenbirk, A. E. (1999). Globalisering van de Nederlandse economie. Maandblad voor Accountancy en Bedrijfskunde (MAB) (November), 608-615.

Holm, U., and Pedersen, T. (2000). The Emergence and Impact of MNC Centres of Excellence. A Subsidiary Perspective. Houndsmills: Macmillan Press Ltd.

Hout, T., Porter, M. E., and Rudden, E. (1982). How Global Companies Win Out. Harvard Business Review, 60 (September-October), 98-108.

Hymer, S. H. (1960 (published 1976)). The International Operations of National Firms: A Study of Direct Investment. Boston: MIT Press.

I

Ilmakunnas, P., and Topi, J. (1999). Microeconomic and Macroeconomic Influences on Entry and Exit of Firms. Review of Industrial Organization, 15 (3), 283-301.

IMD (1999). World Competitiveness Yearbook. Lausanne.

IMF (2000a). Direction of Trade Statistics Yearbook 2000. Washington: International Monetary Fund.

IMF (2000b). International Financial Statistics Yearbook. Washington: International Monetary Fund.

IMF (various issues). World Economic Outlook. Washington: International Monetary Fund.

Institutional Investor (various issues). Country Credit Rankings. Institutional Investor (september/october).

$\mathbf{J}$

Jansen, K. (1995). The Macroeconomic Effects of Direct Foreign Investment: The Case of Thailand. World Development, 23 (2), 193-210.

Johanson, J., and Vahlne, J.-E. (1977). The Internationalization Process of the Firm - A Model of Knowledge Development and Increasing Market Commitments. Journal of International Business Studies, 8 (1), 23-32.

Joly, H., Kluge, J., and Stein, L. (1994). Europe's Structural Weakness. The McKinsey Quarterly (1), 3338.

$\mathbf{K}$

Kasper, H., Helsdingen, P. van and W. de Vries Jr. (1999). Services Marketing Management. An International Perspective. Chichester Wiley \& Sons.

Kemp, R.G.M. (1999) Managing Interdependence for Joint Venture Success. Maastricht: Datawyse.

Kernagahan, C. (1999). Sweatshop Blues. Companies Love Misery, Dollars and Sense, March/April, 1821.

Kim, W. C., and Hwang, P. (1992). Global Strategy and Multinationals' Entry Mode Choice. Journal of International Business Studies, 23 (1), 29-54.

Kindleberger, C. P. (1969). American Business Abroad. New Haven CN: Yale University Press.

Kittiprapas, S., and McCann, P. (1999). Industrial Location Behaviour and Regional Restructuring within the Fifth 'Tiger' Economy: Evidence from the Thai Electronics Industry. Applied Economics, 31 (1), 37-51.

Kleijweg, A. J. M., and Lever, M. H. C. (1996). Entry and Exit in Dutch Manufacturing Industries. Review of Industrial Organization, 11 (3), 375-382.

Kluge, J., Deger, R., and Wunram, J. (1996). Can Germany still Innovate? The McKinsey Quarterly (2), 142-153.

Knickerbocker, F. T. (1973). Oligopolistic Reaction and the Multinational Enterprise. Cambridge MA: Harvard University Press. 
Kogut, B., and Chang, S. (1996). Platform Investment and Volatile Exchange Rates: Direct Investments in the US by Japanese Electronic Companies. Review of Economics and Statistics, 78 (2), 221231.

Kogut, B., and Singh, A. (1988). The Effect of National Culture on the Choice of Entry Mode. Journal of International Business Studies, 19 (2), 411-432.

KPMG (1996a). The 1995 Survey of Foreign Based Companies in the Amsterdam Area. Amsterdam: KPMG.

KPMG (1996b). Investment in the Netherlands . Amsterdam: KPMG Meijburg and Co.

KPMG (1998). The 1997 Survey of Foreign Based Companies in the Rotterdam Region. Rotterdam: KPMG.

Kranenburg, H. L. van, Cloodt, M., and Hagedoorn, J. (2001). An Exploratory Study of Recent Trends in the Diversification of Dutch Publishing Companies in the Multimedia and Information Industries. International Studies of Management and Organization, 31 (1), 64-86.

Krugman, P. (1991). Geography and Trade. Cambridge MA.: MIT Press.

Kuijpers, R. (2001, 11 april 2001). Veel stakers, weinig stakingen. Central Bureau voor de Statistiek. Available: http://www.cbs.nl/nl/nieuws/artikelen/2000/0489k.htm [2001, 9/4/01].

Kumar, N. (1990). Multinational Enterprises in India. London: Routledge.

L

Lall, S. (1980). Monopolistic Advantages and Foreign Involvement by US Manufacturing Industry. Oxford Economic Papers, 32 (1), 102-122.

Lecraw, D. J. (1984). Bargaining Power, Ownership, and Profitibility of Subsidiaries of Transnational Corporations in Developing Countries. Journal of International Business Studies, 15 (Spring/Summer), 27-44.

Levitt, T. (1983). The Globalisation of Markets. Harvard Business Review, 61 (May-June), 92-102.

Liu, X., Song, H., Wei, Y., and Romilly, P. (1997). Country Characteristics and Foreign Direct Investment in China: A Panel Data Analysis. Weltwirtschaftliches Archiv, 133 (2), 313-329.

Loeve, A. (1986). Buitenlandse ondernemingen in Nederland. Economisch-Statistische Berichten (26-2), 220-225.

Love, J. H., and Lage-Hildalgo, F. (2000). Analysing the Determinants of US Direct Investment in Mexico. Applied Economics, 32 (10), 1259-1267.

Lucas, R. B. (1993). On the Determinants of Foreign Direct Investment: Evidence from East and Southeast Asia. World Development, 21 (3), 391-406.

Lunn, J. (1980). Determinants of US Direct Investment in the E.E.C. Further Evidence. European Economic Review, 13 (1), 93-101.

Luostarinen, R. (1979). Internationalization of the Firm. Helsinki: Acta Academie Oeconomicae Helsinki School of Economics.

M

MacLallen, A. (2001). A Tough Year Leaves Lessons for Those Willing to Learn from Their Past, EBN, December 17, 2001, http://www.ebnonline.com, 20, retrieved May 6, 2002.

Maddala, G. S. (1983). Limited Dependent and Qualitative Variables in Econometrics. Cambridge: Cambridge University Press.

Madhok, A., and Phene, A. (2001). The Co-Evolution Advantage: Strategic Management Theory and the Eclectic Paradigm. International Journal of the Economics of Business, 8 (2), 243-256.

Malhotra, N. K. (1996). Marketing Research: An Applied Orientation. (2nd ed.). Upper Saddle River, New Jersey: Prentice Hall, Inc. 
Marshall, A. (1920). Principles of Economics. (8th ed.). London: MacMillan.

Martin, S. (1991). Direct Foreign Investment in the United States. Journal of Economic Behavior and Organization, 16 (3), 283-293.

Mata, J., and Portugal, P. (2000). Closure and Divestiture by Foreign Entrants: The Impact of Entry and Post-Entry Strategies. Strategic Management Journal, 21 (5), 549-562.

Mayhew-Smith, A. (2001). Cutting Remarks, Electronics Weekly, September 26, 2001, http://www.electronicsweekly.co.uk, retrieved May 6, 2002.

McFadden, D. (1974). Conditional Logit Analysis of Qualitative Choice Behavior. In P. Zarembka (Ed.), Frontiers in Econometrics (pp. 105-142). New York: Academic Press Inc.

McFadden, D. (1978). Modelling the Choice of Residential Location. In A. Karlqvist, L. Lundqvist, F. Snickars, and J. W. Weibull (Eds.), Spatial Interaction Theory and Planning Models (pp. 75-96). Amsterdam: North Holland Publishing Company.

Milward, A. S. (1992). The European Rescue of the Nation State. London: Routledge.

Ministry of Economic Affairs (1999). Werving voor werk en welvaart. Motieven en middelen voor het Nederlandse acquisitiebeleid. The Hague: Commissariaat voor Buitenlandse Investeringen in Nederland.

Ministry of Economic Affairs (2000). Vervreemding Twinning. Persbericht 22-09-2000. Ministry of Economic Affairs [2001, 30/5/2001].

Ministry of Economic Affairs (2001). Developments of the Dutch economy: From Dutch Disease to Dutch Miracle. Available: http://www.minez.nl/aep/publications/ rapport/factshen.htm [2001, 5/4/2001].

Minne, B. (1997). International Battle of Giants. The Role of Investment in Research and Fixed Assets . The Hague: Central Planning Bureau.

Mody, A., and Srinivasan, K. (1998). Japanese and US Firms as Foreign Investors: Do They March to the Same Tune? The Canadian Journal of Economics, 31 (4), 778-799.

Mudambi, R. (1995) The MNE Investment Location Decision: Some Empirical Evidence. Managerial and Decision Economics, 16 (3), 249-257.

Muchlinski, P.T. (2001) Human Rights and Multinationals: Is There a Problem? International Affairs, 77 (1), 31-47.

$\mathbf{N}$

Nachum, L. (2000). Economic Geography and the Location of TNCs: Financial and Professional Service FDI to the USA. Journal of International Business Studies, 31 (3), 367-385.

Narula, R. (2001). Multinational Firms, Regional Integration and Globalising Markets: Implications for Developing Countries. Paper presented at the Conference on Regional Integration and Trade in the Development Agenda, Inter-American Development Bank, Washington DC.

Narula, R., and Dunning, J. H. (1999). Developing Countries versus Multinationals in a Globalising World: The Dangers of Falling Behind, Forum for Development Studies, (2), 261-287.

Narula, R., and Dunning, J. (2000). Industrial Development, Globalisation and Multinational Enterprises: New Realities for Developing Countries. Oxford Development Studies, 28 (2), 141-167.

Narula, R., and Hogenbirk, A. E. (1999). Dutch Manufacturing MNEs in the United States, 1950-1995. In R. van Hoesel and R. Narula (Eds.), Multinational Enterprises from the Netherlands (pp. 210240). London: Routledge.

Narula, R., and Wakelin, K. (2001). Determinants of US Direct Investment in the EU and Japan. In R. Narula (Ed.), Trade and Investment in a Globalizing World. Essays in Honour of H. Peter Gray (pp. 55-68). Kidlington: Pergamon.

NFIA (1997a). Back Offices in the Netherlands. The Hague: Netherlands Foreign Investment Agency. 
NFIA (1997b). A Guide: Investment in the Netherlands. The Hague: Netherlands Foreign Investment Agency.

NFIA (1997c). The Netherlands. Europe's Logistics Center. 15 Cases. The Hague: Netherlands Foreign Investment Agency.

NFIA (2001a). Education/R\&D. Netherlands Foreign Investment Agency. Available: http://www.nfia.com/html/location/education.html [2001, 9/18/ 2001].

NFIA (2001b). Rethinking Europe: Transportation. Available: http://www.nfia.com/ $\mathrm{html} /$ location/transportation.html [2001, 9/18/2001].

Nieuwkerk, M. van, and Sparling, R. (1985). The Netherlands International Direct Investment Position. Dordrecht: Nijhoff.

\section{O}

OECD (2000). Economic Surveys: Netherlands. Paris: OECD.

OECD (2001). Education at a Glance. OECD Indicators. Paris: OECD.

OECD (2002). Economic Surveys: Netherlands. Paris: OECD.

O'Gorman, C., and McTiernan, L. (2000). Factors Influencing the Internationalization Choices of Small and Medium-Sized Enterprises: The Case of the Irish Hotel Industry. Enterprise and Innovation Management Studies, 1 (2), 141-151.

Ohmae, K. (1985). Triad Power. New York: Free Press.

Oxfam (2001). Extractive Industries in South America, Available: http:// www. oxfamamerica. org/art815.html [2002, May 4th].

\section{$\mathbf{P}$}

Papanastassiou, M., and Pearce, R. (1994). Host-Country Determinants of the Market Strategies of US Companies' Overseas Subsidiaries. Journal of the Economics of Business, 1 (2), 199-217.

Pearce, R. (2001). Multinationals and Industrialisation: The Bases of "Inward Investment" Policy. International Journal of the Economics of Business, 8 (1), 51-73.

Pearce, R., and Tavares, A. T. (1998). Strategies of Multinational Subsidiaries in a Context of Regional Trading Blocs (Discussion Pepers in International Investment and Management. Series B, Vol. XI 257). Reading: University of Reading, Department of Economics.

Pelkmans, J. (1997). European Integration: Methods and Economic Analysis. Harlow: Addison Wesley/Longman.

Porter, M. E. (1980). Competitive Strategy. New York: The Free Press.

Porter, M. E. (1985). Competitive Advantage. New York: The Free Press.

Porter, M. E. (Ed.). (1986). Competition in Global Industries. Boston: Harvard Business School Press.

Porter, M. E. (1996). The Role of Location in Competition. Journal of Economics of Business, 1 (1), 3539.

Pralahad, C. K., and Doz, Y. L. (1981). An Approach to Strategic Control in MNCs. Sloan Management Review (summer), 5-13.

Prahalad, C. K., and Doz, Y. L. (1987). The Multinational Mission. New York: The Free Press.

$\mathbf{R}$

Ramaswami, S. N. (1992). Choice of Foreign Market Entry Mode: Impact of Ownership, Location and Internalization Factors. Journal of International Business Studies, 23 (1), 1-27.

Reed Electronics Research (2001). The Yearbook of World Electronics Data, Reed Elsevier (www.rer.co.uk). 
Reynolds, M. (2001). Jobs Go as Industry Hit by Force of Downturn, Electronics Weekly, August 1, www.electronicsweekly.co.uk, retrieved May 6, 2002.

Root, F. R. (1987). Entry Strategies for International Markets. Lexington: Lexington Books.

Rosenzweig, P. and Singh, J. (1991) Organizational Environments and the Multinational Enterprise. Academy of Management Review, 16, 340-361.

Rugman, A. M. (1979). International Diversification and the Multinational Enterprise. Lexington MA: Lexington Books.

Rugman, A. M. (1982). New Theories of the Multinational Enterprise. London: Croom Helm.

\section{S}

Safarian, A. E. (1999). Host Country Policies towards Inward Foreign Direct Investment in the 1950s and 1990s. Transnational Corporations, 8(2), 93-112.

Scaperlanda, A., and Balough, R. (1983). The Determinants of US Direct Investment in the EEU: Revisited. European Economic Review, 21 (3), 381-90.

Schmutzler, A. (1999). The New Economic Geography. Journal of Economic Surveys, 13 (4), 355-379.

Schneider, F., and Frey, B. S. (1985). Economic and Political Determinants of Foreign Direct Investment. World Development, 13 (2), 161-175.

Schollhammer. H. (1971) Organization Structures of Multinational Companies, Academy of Management Journal, 14 (September), 345-365.

Schuur, J. (1999). Industrial Landuse Planning in the Netherlands (99/4). The Hague: Centraal Planbureau.

Shapiro, D., and Khemani, R. S. (1987). The Determinants of Entry and Exit Reconsidered. International Journal of Industrial Organization, 5 (1), 15-26.

Shaver, J. M. (1998). Do Foreign-Owned and US-Owned Establishments Exhibit the Same Location Pattern in the US Manufacturing Industries? Journal of International Business Studies, 29 (3), 469-492.

Siegfried, J. J., and Evans, L. B. (1994). Empirical Studies of Entry and Exit: A Survey of the Evidence. Review of Industrial Organization, 9 (2), 121-155.

Steffen, C. (1998). The Dutch "Polder Model" - An Answer to the German Crisis? Available: http:// tiss.zdv.uni-tuebingen.de/webroot/sp/spsba01_W98_1/germany10.htm [2001, April 5th].

Stibora, J., and Vaal, A. de (1999). Services FDI and the Dutch Economy. In R. van Hoesel and R. Narula (Eds.), Multinational Enterprises from the Netherlands (pp. 138-171). London: Routledge.

Streeten, P. (1993). The Special Problems of Small Countries. World Development, 21 (2), 197-202.

Strizzi, N., and Kindra, G. S. (1997). A Survey of Canadian Countertrade Practices with Asia-Pacific Countries. Revue Canadienne des sciences de l'administration, 14 (4), 417-423.

Stubenitsky, F. (1970). American Direct Investment in Netherlands Industry. Rotterdam: Rotterdam University Press.

$\mathbf{T}$

Taggart, J. H. (1996). Multinational Manufacturing Subsidiaries in Scotland: Strategic Role and Economic Impact. International Business Review, 5 (5), 447-468.

Taggart, J. H. (1997a). Autonomy and Procedural Justice: A Framework for Evaluating Subsidiary Strategy. Journal of International Business Studies, 28 (1), 51-77.

Taggart, J. H. (1997b, December). Constituents of Subsidiary Strategy. Paper presented at the European International Business Academy Conference, Stuttgart, Germany.

Tallman, S. B. (1988). Home Country Political Risk and Foreign Direct Investment in the United States. Journal of International Business Studies, 19 (summer), 219-234. 
Tatoglu, E., and Glaister, K. W. (1998a). Determinants of Foreign Direct Investment in Turkey. Thunderbird International Business Review, 40 (3), 279-314.

Tatoglu, E., and Glaister, K. W. (1998b). Western MNCs' FDI in Turkey: An Analysis of Location Specific Factors. Management International Review, 38 (2), 133-159.

Teece, D. J. (1981). The Multinational Enterprise: Market Failure and Market Power Consideration. Sloan Management Review, 22 (3), 3-17.

Terpstra, V., and Yu, C.-M. (1988). Determinants of Foreign Investment in the U.S. Advertising Agencies. Journal of International Business Studies, 19 (Spring), 33-46.

The Economist (1998). Small but Perfectly Formed. The Economist, 346 (8049), 65-67.

The Economist (2002). Model Makers. A Survey of the Netherlands. The Economist, May 4th.

Tse, D. K., Pan, Y., and Au, K. Y. (1997). How MNCs Choose Entry Modes and Form Alliances: The China Experience. Journal of International Business Studies, 28 (4), 779-805.

Tucker, L. R., Jain, S. C., and Failer, B. (1992). Factors Affecting the Decision to Invest in Eastern Europe. Scandinavian International Business Review, 1 (2), 3-20.

Tulder, R. van (1999). Small, Smart and Sustainable? Policy Challenges to the Dutch Model of Governance (Together) with Multinationals. In R. van Hoesel and R. Narula (Eds.), Multinational Enterprises from the Netherlands (pp. 282-301). London: Routledge.

Tulder, R. van, Berghe, D. van den, and Muller, A. (2001). Erasmus (S)coreboard of Core Companies. The World's Largest Firms and Internationalization. Rotterdam: Rotterdam School of Management.

U

United Nations (1997). World Investment Report 1997 Transnational Corporations, Market Structure and Competition Policy. New York: United Nations.

United Nations (1998). World Investment Report 1998: Trends and Determinants. New York: United Nations.

United Nations (1999). World Investment Report 1999 Foreign Direct Investment and the Challenges of Development. New York: United Nations.

United Nations (2000). World Investment Report 2000. Cross-border Mergers and Acquisitions and Development. New York: United Nations.

United Nations (vd). World Investment Report. New York: United Nations.

\section{V}

Van den Bulcke, D. (1983). Multinationale ondernemingen in de Europese Gemeenschap. Maandschrift Economie, 47, 304-326.

Venables, A. J. (1998). The Assessment: Trade and Location. Oxford Review of Economic Policy, 14 (2), 1-6.

Vernon, R. (1966). International Investment and International Trade in the Product Cycle. Quarterly Journal of Economics, 80, 190-207.

Vries, J. de, and Woude, A. van der (1995). Nederland 1500-1815. De eerste ronde van moderne economische groei. Amsterdam.

$\mathbf{W}$

Walschots, J. (2001). Waarom heeft Nederland de hoogste inflatie van Europa? CBS Webmagazine, 22 oktober 2001. 
Walsh, V. (1988). Technology and Competitiveness of Small Countries: A Review. In C. Freeman and B.-A. Lundvall (Eds.), Small Countries Facing the Technological Revolution (pp. 37-66). London: Pinter Publishers.

Wang, Z. Q., and Swain, N. J. (1995). The Determinants of Foreign Direct Investment in Transforming Economies: Empirical Evidence from Hungary and China. Weltwirtschafliches Archiv, 131 (1), 359-382.

Welch, L., and Luostarinen, R. (1988). Internationalization: Evolution of a Concept. Journal of General Management, 14 (2), 36-64.

Welford, R., and Prescott, K. (1996). European Business. (3rd ed.). London: Pitman Publishing.

Wheeler, D., and Mody, A. (1992). International Investment Location Decisions: The Case of US Firms. Journal of International Economics, 33 (1/2), 57-76.

White, R. E., and Poynter, T. A. (1984). Strategies for Foreign-Owned Subsidiaries in Canada. Business Quarterly, 49 (Summer), 59-69.

Williams, B. (1997). Positive Theories of Multinational Banking: Eclectic Theory versus Internalisation Theory. Journal of Economic Surveys, 11 (1), 71-100.

Williamson, O. E. (1985). The Economic Institutions of Capitalism. New York: The Free Press.

Wilson, B. (1980). The Propensity of Multinational Companies to Expand through Acquisitions. Journal of International Business Studies, 11 (1), 59-65.

Wintjens, R. (2001). Regionaal-economische effecten van buitenlandse bedrijven. (Vol. 286). Utrecht: Koninklijk Nederlands Aardrijkskundig Genootschap.

Woodward, D. P. (1992). Locational Determinants of Japanese Manufacturing Start-ups in the United States. Southern Economic Journal, 58 (3), 690-708.

World Bank (2000). World Development Report 1999/2000. Oxford: Oxford University Press.

World Bank (various issues). World Development Report. New York: Oxford University Press.

Wu, X., and Strange, R. (2000). The Location of Foreign Insurance Companies in China. International Business Review, 9 (3), 383-398.

$\mathbf{Y}$

Yang, J. Y. Y., Groenewold, N., and Tcha, M. (2000). The Determinants of Foreign Direct Investment in Australia. Economic Record, 76 (232), 45-54.

\section{$\mathbf{Z}$}

Zanden, J. L. van (1993). The Rise and Decline of Holland's Economy. Merchant Capitalism and the Labour Market. Manchester: Manchester University Press.

Zanden, J. L. van (1997). Een klein land in de twintigste eeuw. Utrecht: Het Spectrum.

Zander, I., and Zander, U. (1996). Sweden. In J. H. Dunning and R. Narula (Eds.), Foreign Direct Investment and Governments: Catalysts for Economic Restructuring (pp. 101-141). London: Routledge.

Zhang, L. (1994). Location-Specific Advantages and Manufacturing Direct Investment in South China. World Development, 2 (1), 45-53.

Zhang, X., and Yuk, H. P. (1998). Determinants of Hong Kong Manufacturing Investment in China: A Survey. Marketing Intelligence and Planning, 16 (4), 260-267.

Zhao, H., and Zhu, G. (2000). Location Factors and Country-of-Origin Differences: An Empirical Analysis of FDI in China. Multinational Business Review, 8 (1), 60-73. 


\section{BUITENLANDSE INVESTERINGEN IN NEDERLAND}

\section{Introductie}

Dit proefschrift onderzoekt waarom buitenlandse multinationale ondernemingen Nederland kiezen als vestigingsplaats voor hun dochterondernemingen. Hoewel Nederland een relatief klein land is (met name als men kijkt naar het aantal inwoners en de oppervlakte) blijkt het een aantrekkelijke locatie voor buitenlandse ondernemingen te zijn. Nederland behoort zelfs tot de top 5 van landen die door de jaren heen de meeste buitenlandse investeringen hebben aangetrokken. De vier andere landen zijn "grote' landen, de Verenigde Staten, het Verenigd Koninkrijk, China en Duitsland. Het wetenschappelijk onderzoek dat gericht is op het verklaren van de investeringsstromen tussen landen heeft zich met name gericht op deze grote landen. Over de determinanten van investeringen in kleine landen is veel minder bekend. Kleine landen worden meestal gezien als relatief onaantrekkelijke locaties omdat ze doorgaans over een kleine(re) afzetmarkt beschikken en geen of weinig unieke grondstoffen kunnen bieden aan de investeerder. Toch proberen overheden van kleine landen buitenlandse investeerders aan te trekken omdat de investeringen leiden tot aanzienlijke kapitaalinjecties in de locale economie. Bovendien gaan de investeringen vaak gepaard met overdracht van technologie en kennis (o.a. van marketing-, distributie- en managementtechnieken) en ook dit kan een belangrijke bijdrage leveren aan de economie van het gastland. Het is daarom belangrijk de determinanten van dergelijke investeringen te onderzoeken. Inzicht in de factoren die het relatieve succes van Nederland verklaren kan andere kleine landen die graag meer investeringen willen aantrekken helpen een effectief investeringsklimaat te ontwikkelen.

\section{Onderzoeksvragen}

Er is veel onderzoek verricht naar de bijzondere positie die Nederlandse multinationals (zoals Philips, Ahold, Unilever en ABN-Amro) innemen in de wereld. Er is echter veel minder bekend over de determinanten van de aantrekkingskracht van Nederland op buitenlandse multinationals zoals Sony (Japan), Siemens (Duitsland), Hewlett Packard en IBM (Verenigde Staten), Nestlé (Switzerland) en Ericsson (Zweden). Belangrijke vragen in dit kader zijn: welke buitenlandse bedrijven hebben een vestiging in Nederland? Wat motiveert deze bedrijven om in Nederland een dochteronderneming te openen? Waar bevinden deze bedrijven zich? Als deze bedrijven zich in Nederland hebben gevestigd, hoe gedragen ze zich dan? Richten ze zich enkel op de Nederlandse consumenten of is 
wellicht de steeds verder geïntegreerde Europese markt van doorslaggevend belang? Dit proefschrift geeft antwoorden op deze vragen.

\section{Elektronica}

Voor een deel van het onderzoek is gebruik gemaakt van een enquête waarbij specifiek gekeken is naar de buitenlandse elektronicabedrijven in Nederland. De elektronicaindustrie is om meerdere redenen gekozen. In Europa kwam zij al vroeg tot ontwikkeling. De Nederlandse onderneming Koninklijke Philips Electronics B.V. is een van de oudste elektronicabedrijven ter wereld. De laatste decennia is er concurrentiedruk op de 'oude' Europese bedrijven ontstaan door toetreders uit o.a. Japan (Hitachi, Sony, Matsushita, Toshiba, Canon) en de Verenigde Staten (IBM, Hewlett-Packard). Bovendien is de industrie zeer dynamisch. Bedroeg de levenscyclus van een mechanische typemachine nog zo'n 35 jaar, tegenwoordig wordt computersoftware iedere zes maanden veranderd. Om niet achterop te raken in de markt worden bedrijven in deze industrie daardoor gedwongen te investeren in nieuwe onderzoeksprojecten en moeten zij bovendien hun producten zo snel mogelijk bij zoveel mogelijk consumenten onder de aandacht zien te brengen. De productie omvat goederen die variëren van televisies tot halfgeleiders (semiconductors) waardoor de invloed van deze industrie op het dagelijks leven bijzonder groot is. Verder is deze industrie zowel kapitaal- als arbeidsintensief. Een relatief groot deel van de assemblage vindt handmatig plaats, waardoor er veel werkgelegenheid in de industrie is. Tenslotte blijkt uit de analyses die in het kader van dit onderzoek zijn uitgevoerd dat er relatief veel buitenlandse elektronica-productievestigingen in Nederland zijn.

\section{Analysemethoden}

De verschillende studies in dit proefschrift maken gebruik van diverse databronnen met gegevens over de in Nederland aanwezige buitenlandse investeerders. Door het empirische karakter van de studies ligt de nadruk vooral op kwantitatieve analysetechnieken. In de verschillende hoofdstukken worden telkens andere technieken gebruikt, die voor de situatie het meest geschikt waren. Zo makt hoofdstuk 3 gebruik van een regressie analyse om de macro-economische verklaringen voor de inkomende investeringen in Nederland te toetsen. Vervolgens is er in hoofdstuk 4 een conditionele logistische regressie toegepast om de keuze voor bepaalde gebieden of provincies in Nederland te verklaren. In hoofdstuk 5 wordt met behulp van factor analyse en analyses van de variantie (anova) en t-toetsen gezocht naar de verklaringen voor de buitenlandse investeringen in de elektronica industrie in Nederland. In hoofdstuk 6 tenslotte, wordt met behulp van een logistische regressie gekeken naar de factoren die verklaren of een buitenlands elektronica bedrijf zich enkel op de Nederlandse markt richt of juist een bredere (bijvoorbeeld Europese) markt bedient vanuit een vestiging in Nederland. De verschillende onderzoeken passen wisselende perspectieven toe en de resultaten dragen bij aan de bestaande literatuur. Deze Nederlandse samenvatting geeft kort de gevonden 
empirische resultaten uit het onderzoek weer. In de individuele hoofdstukken worden de gebruikte onderliggende theorieën uitgebreid bespoken. Ook worden aldaar alternatieve verklaringen voor de gevonden resultaten aangedragen. In deze samenvatting wordt hier verder niet aan gerefereerd.

\section{Wie?}

Om de vraag te beantwoorden welke buitenlandse bedrijven er nu precies in Nederland aanwezig zijn, is er speciaal voor dit onderzoek een databestand, DutchInvest, gecreëerd. Dit DutchInvest-bestand dient als uitgangspunt voor de verdere analyses. In het bestand zijn voor 7484 in Nederland gevestigde buitenlandse bedrijven gegevens verzameld die betrekking hebben op het land van herkomst, het jaar van vestiging, de belangrijkste activiteit, het aantal werknemers en de precieze locatie in Nederland. Deze vestigingen blijken werk te verschaffen aan ruim 370.000 mensen.

De activiteiten van deze bedrijven zijn divers. Er zijn relatief veel handelsondernemingen en financiële instellingen onder de buitenlandse bedrijven in Nederland. Slechts een op de acht bedrijven heeft productie als hoofdactiviteit. In deze laatste groep bevinden zich voornamelijk elektronicabedrijven en chemieconcerns.

De meeste multinationale ondernemingen hebben hun hoofdzetel in een van de volgende vijf landen: Verenigde Staten, Verenigd Koninkrijk, Duitsland, België en Frankrijk. Recentelijk zijn ook de Japanse investeringen in Nederland toegenomen.

Veel nieuwe investeringen vonden plaats in de periode tussen 1986-1995. Heel oude bedrijven (gestart rond 1900) die nu in buitenlandse handen zijn, blijken vaak een of meerdere keren te zijn overgenomen door een buitenlandse onderneming. Meestal zijn deze bedrijven oorspronkelijk opgericht door Nederlandse ondernemers. Een uitgebreide beschrijving van de DutchInvest database wordt gegeven in Appendix A.

\section{Waar?}

In hoofdstuk vier is onderzocht welke locaties binnen Nederland als vestigingsplaats worden gekozen. Hoewel zowel Nederlandse als buitenlandse bedrijven een grote voorkeur voor de Randstad hebben, blijken er toch verschillen in de vestigingspatronen te bestaan. In de noordelijke provincies (Groningen, Friesland en Drenthe) komen bijna geen buitenlandse vestigingen voor. In het zuiden profiteren Noord Brabant en Limburg van de grens met België en/of Duitsland. Verder blijkt in hoofdstuk vier dat veel nieuwe buitenlandse bedrijven die zich in Nederland vestigen kiezen voor een locatie in de nabijheid van andere buitenlandse bedrijven. Hopend op agglomeratie-voordelen clusteren deze ondernemingen samen. In Nederland blijken de regionale verschillen in arbeidsaanbod, belastingen, bruto nationaal product en infrastructuur zo klein te zijn dat ze geen doorslaggevende invloed uitoefenen op de locatiekeuze. Opmerkelijk is dat bedrijven waarvan de hoofdzetel op grote geografisch afstand van Nederland is (zoals Japan of de VS) voor hun dochterondernemingen over het algemeen vaker een locatie in de Randstad kiezen dan bedrijven uit Europa. 


\section{Waarom?}

Waarom de buitenlandse ondernemingen voor Nederland kiezen, blijkt met name uit hoofdstuk 3 en 5 van dit proefschrift. De macro-economische analyse in hoofdstuk drie toont aan dat vooral de bekendheid met de Nederlandse markt door middel van handelsrelaties een belangrijke verklaring voor de buitenlandse investeringsstromen vormt. Verrassend genoeg blijken ook de relatief hoge lonen buitenlandse investeringen aan te trekken. Dit feit is verklaarbaar als het loon wordt gezien als een indicator van de kwaliteit van de werknemers. Nederlanders zijn over het algemeen hoogopgeleid en spreken diverse talen waardoor ze aantrekkelijke werknemers zijn voor buitenlandse ondernemingen. Een grote culturele afstand tussen Nederland en het moederland blijkt vestiging in Nederland te hinderen. Het is dan moeilijker voor de multinationale onderneming om in Nederland te opereren.

Om voor elektronicabedrijven te achterhalen waarom zij voor Nederland hebben gekozen is gebruik gemaakt van een enquête. Dit onderzoek werd in het najaar van 1999 uitgevoerd. Bijna 20 procent van de benaderde bedrijven bleek bereid om aan het onderzoek mee te werken. $\mathrm{Zij}$ vulden een uitgebreide vragenlijst in waarin het belang van een groot aantal locatiefactoren werd getoetst. Op basis van de resultaten van deze enquête wordt in hoofdstuk vijf geconcludeerd dat de belangrijkste reden voor vestiging in Nederland voor de elektronicabedrijven bestaat uit de noodzaak om dicht bij de consument te zijn. Verder verwachten deze bedrijven een groeimarkt voor hun product in Nederland, is de marktgrootte en de koopkracht in Nederland van belang en willen de bedrijven graag de meertalige beroepsbevolking als werknemer. Marktfactoren blijken dus heel belangrijk. Voor ongeveer de helft van de geënquêteerde bedrijven moet de markt worden opgevat als het hele Europese continent en niet slechts Nederland alleen. Bedrijven die zich richten op de Europese markt blijken ook veel nadruk te leggen op de makkelijke toegang tot de Europese markt, de centrale geografische ligging van Nederland binnen Europa en het feit dat Nederland deel uitmaakt van de Europese Unie. Bedrijven die hun Nederlandse vestiging als export-platform gebruiken voor de rest van Europa benadrukken daarbij tevens de infrastructurele factoren zoals de luchthaven Schiphol, de transportmogelijkheden en de beschikbaarheid van kantoorruimte.

\section{Wat?}

In het onderzoek is tenslotte ook gekeken naar het gedrag van de multinationale onderneming. Uit de enquête blijkt dat vrijwel alle buitenlandse elektronicabedrijven de Nederlandse markt eerst met behulp van exporten hebben verkend. Toen bleek dat er voldoende vraag naar hun product bestond, hebben ze een locale vestiging geopend. In de nabije toekomst blijken veel ondernemingen uitbreidingsplannen te hebben. $\mathrm{Zij}$ willen dit realiseren door autonome groei en overwegen tevens hiervoor bedrijven aan te kopen.

Bijna de helft van de bedrijven in het onderzoek blijkt de producten niet enkel in Nederland af te zetten maar ook vanuit Nederland te exporteren naar andere, vaak Europese, markten. In hoofdstuk zes blijkt dat de doorslaggevende factoren om te gaan 
exporteren leeftijd, activiteit, functie en moederland van de onderneming te zijn. Exporterende bedrijven zijn nog niet zo lang in Nederland, hebben locale productieactiviteiten en zijn een Europees hoofdkantoor voor een multinational die buiten Europa een hoofdzetel heeft. In veel gevallen heeft de moederonderneming weinig andere dochters in Europa.

\section{Knelpunten?}

Hoewel Nederland over het algemeen dus een aantrekkelijke locatie voor buitenlandse ondernemingen is gebleken is er in de enquête ook een sectie gewijd aan de knelpunten die buitenlandse elektronicabedrijven in Nederland ervaren. Omdat tegenwoordig een groot deel van alle buitenlandse investeringen bestaat uit uitbreidingsinvesteringen, is het belangrijk eventuele knelpunten op te lossen. Als de ergernis te groot wordt, bestaat het risico dat het moederbedrijf besluit de activiteiten te verplaatsen naar een andere locatie (binnen Europa). Uit de analyse in appendix D blijkt dat er twee belangrijke knelpunten bestaan. Het eerste betreft de infrastructuur. Omdat Nederland een van de dichtstbevolkte gebieden van de wereld is, veroorzaakt de (toegenomen) mobiliteit vaak files. Hoewel de overheid dit probleem tracht te verhelpen (o.a. met het bereikbaarheidsoffensief voor de Randstad), zijn veel buitenlandse bedrijven nog niet tevreden. Ook de kosten van transport worden als een belemmering ervaren. Het tweede knelpunt betreft de krapte op de arbeidsmarkt voor hooggekwalificeerde (technische) arbeid. Door de geringe beschikbaarheid wordt technisch personeel relatief duur. Men ervaart ook krapte op de markt voor commercieel personeel. Commercieel talent is uitermate belangrijk voor buitenlandse bedrijven omdat marketing en handel een aanzienlijk deel van hun activiteiten uitmaken.

\section{Conclusies}

Concluderend kunnen we stellen dat Nederland relatief succesvol is geweest in het aantrekken van buitenlandse investeringen. De unieke locatie van Nederland binnen Europa speelt een belangrijke rol in de overwegingen van buitenlandse ondernemers om zich in Nederland te vestigen. Als een bedrijf door het exporteren van goederen en diensten ervaring met de Nederlandse markt heeft opgedaan en er voldoende markt voor zijn producten is, in Nederland zelf of in Europa als geheel, wordt het aantrekkelijk om in Nederland een vestiging te openen of een bestaand bedrijf op te kopen. Door de gunstige locatie van Nederland in de Europese Unie en goede verbindingen met de Europese markt is het mogelijk een grote(re) afzet te bereiken. Met name de locale infrastructuur en de krappe arbeidsmarkt blijken knelpunten te zijn die het buitenlandse bedrijven lastig maken in of vanuit Nederland te opereren. Andere kleine landen kunnen van het Nederlandse succes leren dat niet zozeer de eigen thuismarkt doorslaggevend hoeft te zijn, maar veeleer de makkelijke bereikbaarheid van een grote regionale markt de keuze voor een vestigingsplaats kan beïnvloeden. Ook loont het om te investeren in het opleidings- en vaardighedenniveau van de bevolking. 


\section{Curriculum Vitae}

Annelies (Anne Elisabeth) Hogenbirk was born on the $25^{\text {th }}$ of November 1970 in Huizen (the Netherlands). After finishing secondary school at the Willem de Zwijger School in Schoonhoven, she studied Economics at the faculty of Economics and Business Administration at Maastricht University and Development Planning at the Erasmus University in Rotterdam. One year before her graduation (in May 1995), she started working as a research assistant at the United Nations University - Institute for New Technologies (UNU-Intech) in Maastricht. In October 1996 she started as a PhD student at Maastricht University. She is currently working as a researcher at the Economic Research Unit of Rabobank Nederland in Utrecht.

Annelies (Anne Elisabeth) Hogenbirk werd op 25 november 1970 geboren in Huizen. In 1989 voltooide zij het Atheneum aan de Willem de Zwijger Scholengemeenschap te Schoonhoven. Vervolgens studeerde zij Algemene Economie aan de Economische Faculteit van de Universiteit Maastricht en volgde tevens het doctoraal programma van de opleiding Ontwikkelingplanning aan de Erasmus Universiteit in Rotterdam. Nog voor haar afstuderen in mei 1995 begon zij als onderzoeksassistent te werken bij de United Nations University - Institute for New Technologies (UNU-Intech) te Maastricht. In oktober 1996 is zij als Assistant in Opleiding (AiO) in dienst van de Universiteit Maastricht getreden. Thans is zij werkzaam als onderzoeker bij de Stafgroep Economisch Onderzoek van Rabobank Nederland in Utrecht. 


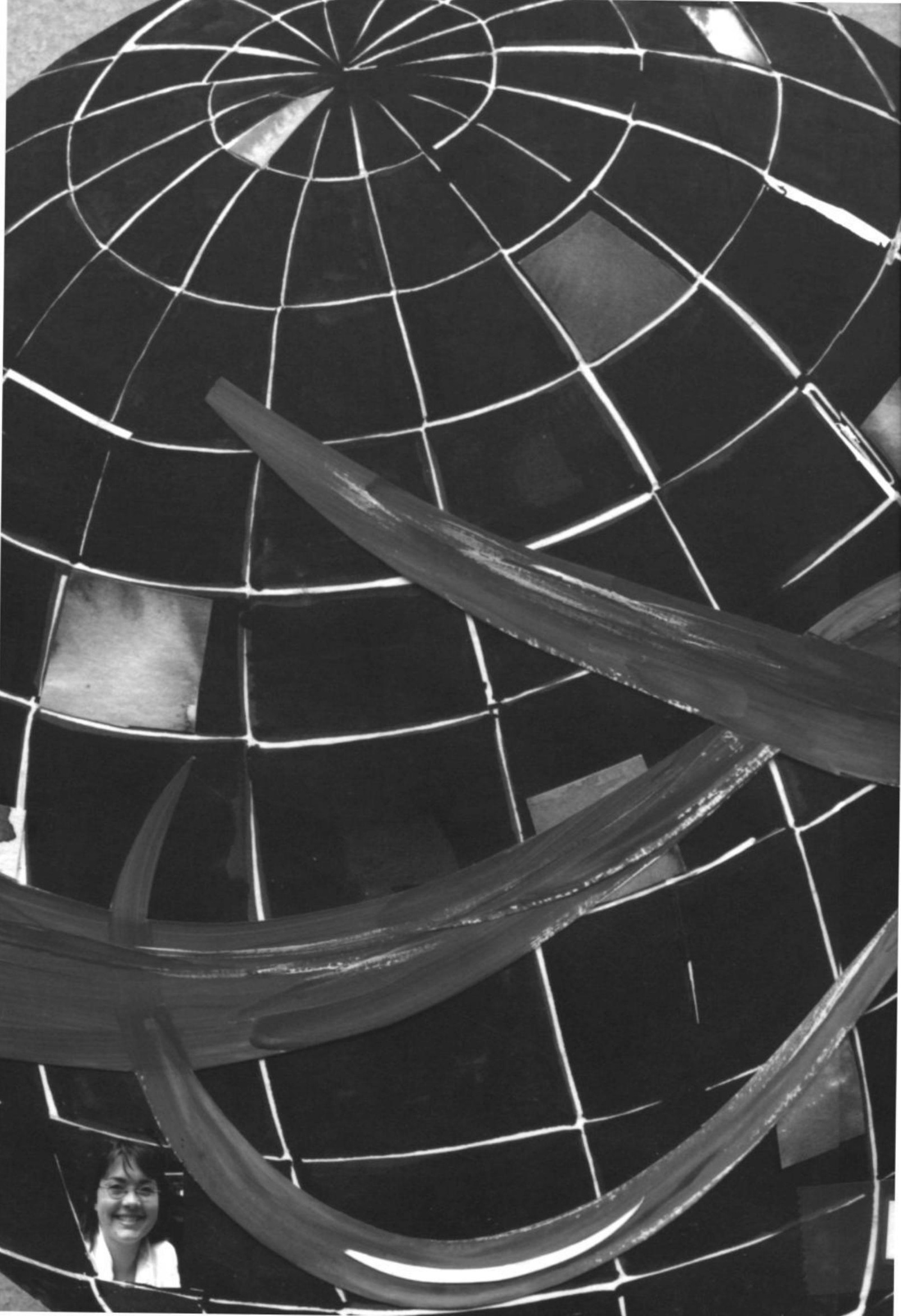

